\title{
CORPORATE GOVERNANCE, INFORMATION INTERMEDIATION, AND EARNINGS MANAGEMENT
}

\author{
Dissertation \\ zur Erlangung des Doktorgrades \\ der Wirtschaftswissenschaftlichen Fakultät \\ der Georg-August-Universität Göttingen
}

vorgelegt von

Nico Lehmann

geboren in Kyritz

Göttingen, 2014 
Erstgutachter: $\quad$ Prof. Dr. Jörg-Markus Hitz

Zweitgutachter: $\quad$ Prof. Dr. Olaf Korn

Tag der mündlichen Prüfung: 24.09.2014 
Diese Dissertation ist meinen Eltern gewidmet. 


\begin{abstract}
Based on four empirical studies, this thesis investigates the interrelation of corporate governance, information intermediation, and earnings management. First, the thesis complements the discussion initiated by the European Securities and Market Authorities about the role of proxy advisors at European shareholder meetings by providing empirical evidence on the influence and method consistency of these advisors for a European setting (Study 1). The respective findings are twofold; they indicate a significant correlation between negative proxy voting recommendations and voting dissent as well as a certain method consistency of these recommendations with respect to the employed governance perceptions. Second, the thesis augments prior work on the usefulness of commercial corporate governance ratings by shedding light on the incremental contribution of the rating vendor's information processing activities (Study 2). The findings of this study suggest that governance rating vendors do not create value in the process of converting public data into aggregated ratings. Third, the thesis extends the perspective of prior research on proxy voting advisory and governance ratings by highlighting the role of corporate governance analysts (Study 3). In doing so, it provides empirical evidence on potential economic consequences of governance analyst coverage. The respective findings suggest that governance analysts serve as information intermediaries by enhancing the firm's information environment and by promoting external monitoring to managers. Fourth and lastly, the thesis adds to research on the link between governance quality and earnings management by highlighting the setting-specific nature of this relationship (Study 4). Specifically, it examines whether the acquirer's governance quality affects the acquirer's earnings management behavior prior to share-based M\&A transactions. The study's findings suggest that - in contrast to common claims that strong governance constrains earnings management - acquirers with strong governance engage more aggressively in incomeincreasing accruals manipulation than those with weak governance. Overall, the thesis contributes to prior literature by, first, providing insights into the economic role of corporate governance advisory on capital markets and, second, by highlighting the setting-specific nature of the governance and earnings management relationship.
\end{abstract}


SUMMARY OF CONTENTS

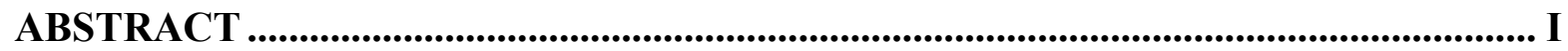

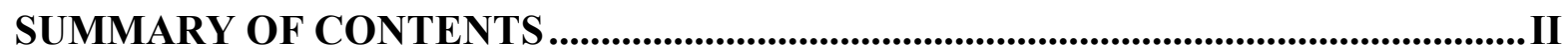

TABLE OF CONTENTS............................................................................................. III

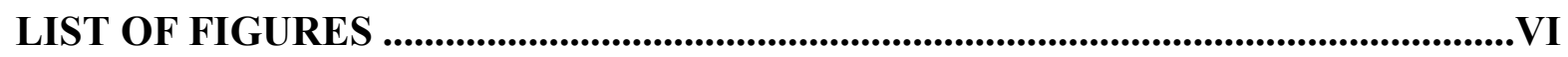

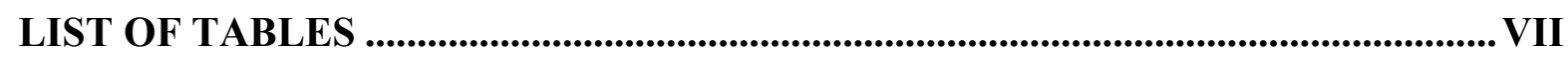

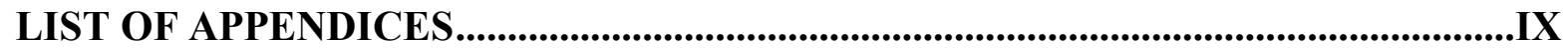

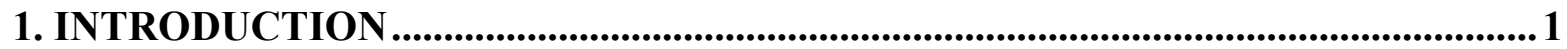

2. DOES PROXY VOTING ADVISORY MATTER IN A EUROPEAN CONTEXT? EVIDENCE FROM GERMAN ANNUAL MEETINGS ........................ 12

3. THE USEFULNESS OF CORPORATE GOVERNANCE RATINGS INSIGHTS FROM EUROPEAN SETTINGS ............................................................51

4. DO CORPORATE GOVERNANCE ANALYSTS MATTER? EVIDENCE FROM A QUASI-NATURAL EXPERIMENT ...................................................100

5. THE ROLE OF CORPORATE GOVERNANCE IN SHAPING ACCRUALS MANIPULATION PRIOR TO ACQUISITIONS........................................................... 141

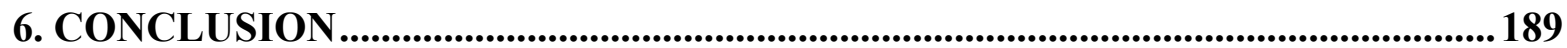

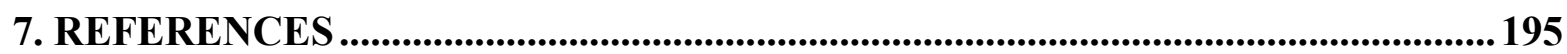

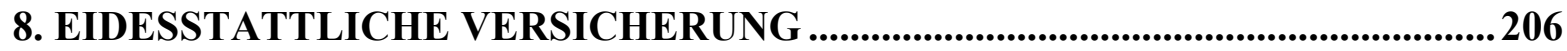

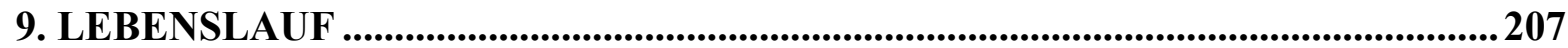




\section{TABLE OF CONTENTS}

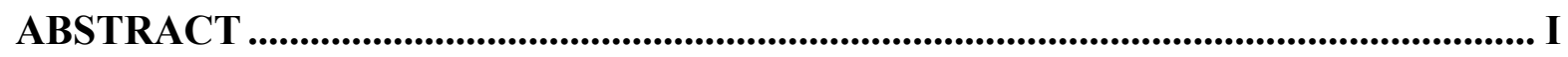

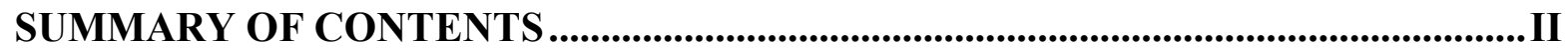

TABLE OF CONTENTS............................................................................................ III

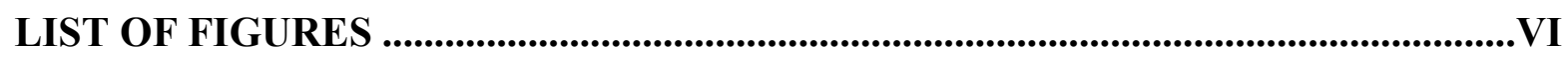

LIST OF TABLES ....................................................................................................... VII

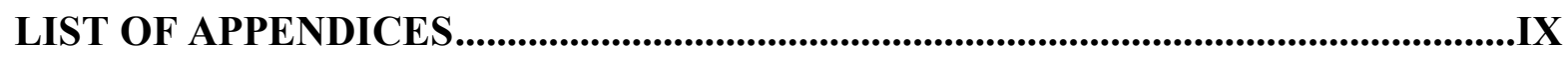

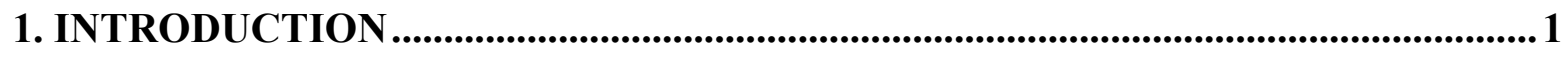

1.1 Context of the Thesis ........................................................................................................................ 1

1.2 Objectives and Contribution of the Thesis.........................................................................5

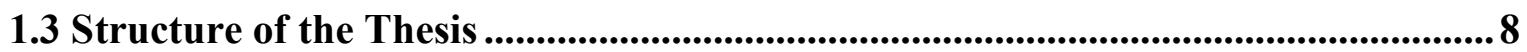

2. DOES PROXY VOTING ADVISORY MATTER IN A EUROPEAN

CONTEXT? EVIDENCE FROM GERMAN ANNUAL MEETINGS ....................... 12

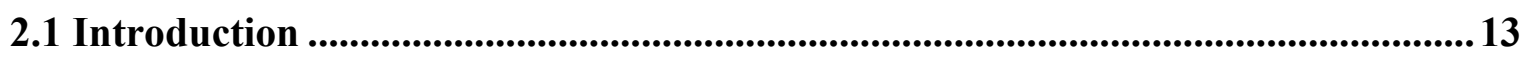

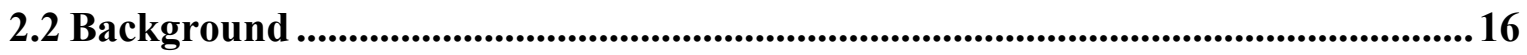

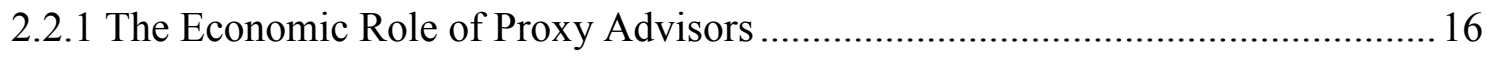

2.2.2 German Shareholder Meetings and Proxy Advisory ........................................ 17

2.2.3 The European Proxy Advisory Business ....................................................... 17

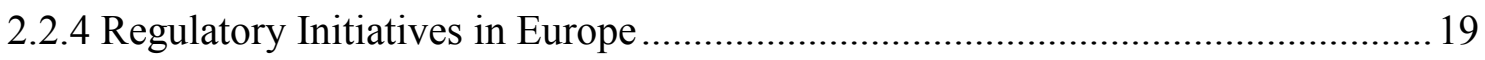

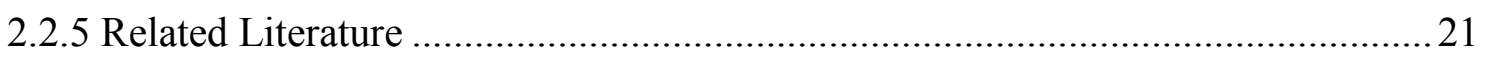

2.3 Empirical Predictions...........................................................................................................25

2.4 Regression Models ................................................................................................................ 27

2.5 Results ...........................................................................................................................29

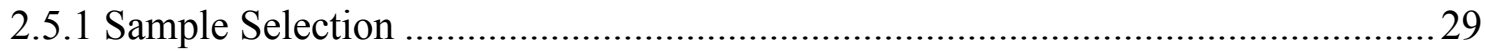

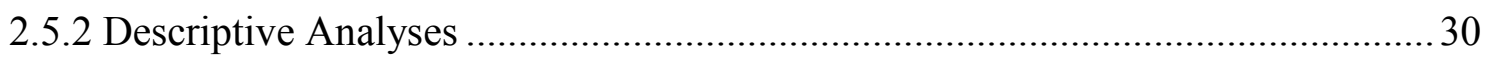

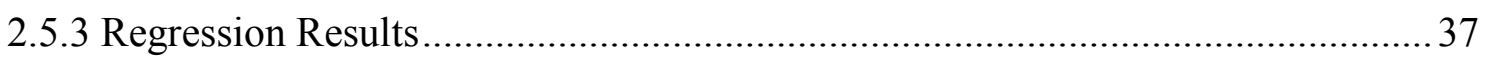

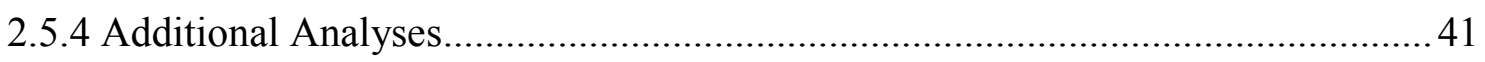

2.6 Conclusion ............................................................................................................................ 47

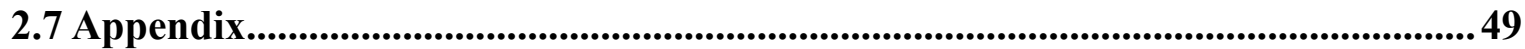

3. THE USEFULNESS OF CORPORATE GOVERNANCE RATINGS INSIGHTS FROM EUROPEAN SETTINGS ........................................................5 51

3.1 Introduction ............................................................................................................................552 
3.2 Background and Related Literature.......................................................................54

3.2.1 Commercial Corporate Governance Ratings ....................................................... 54

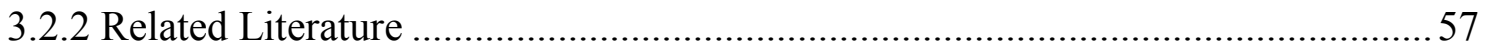

3.3 Empirical Predictions.................................................................................59

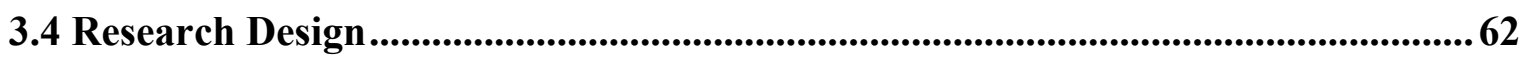

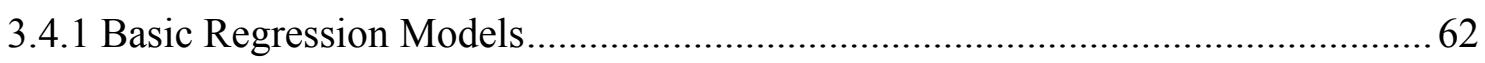

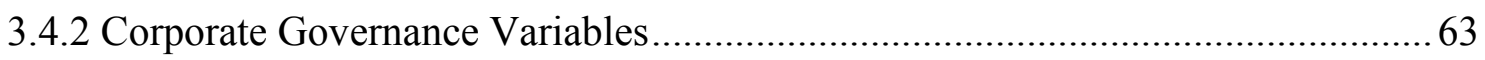

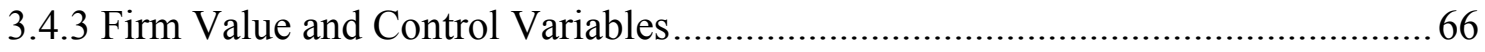

3.5 Results................................................................................................................................................. 67

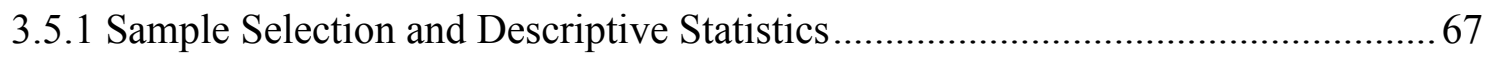

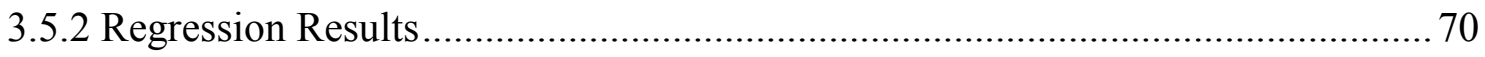

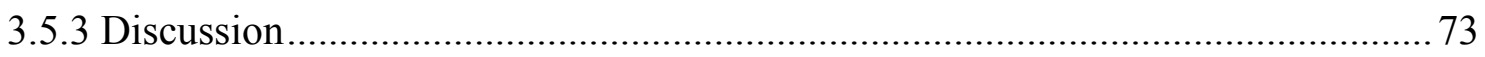

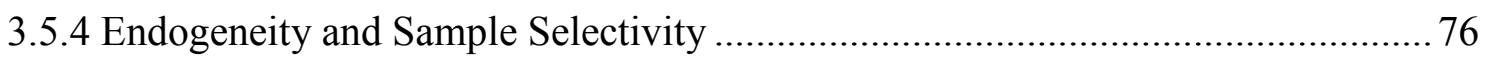

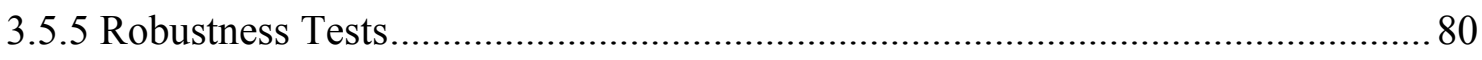

3.6 Conclusion ............................................................................................................................. 84

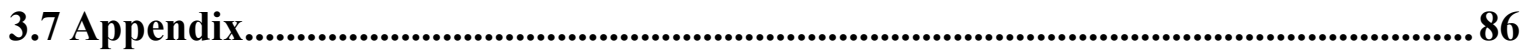

4. DO CORPORATE GOVERNANCE ANALYSTS MATTER? EVIDENCE FROM A QUASI-NATURAL EXPERIMENT ........................................................ 100

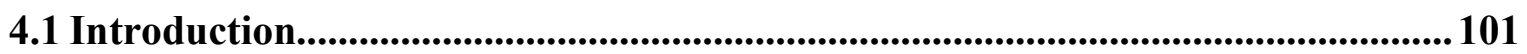

4.2 Background ................................................................................................................................. 104

4.3 Empirical Predictions........................................................................................................ 105

4.4 Research Design ..........................................................................................................110

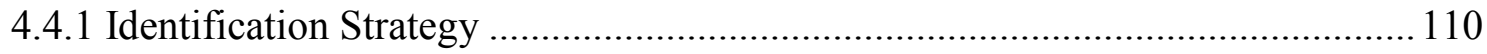

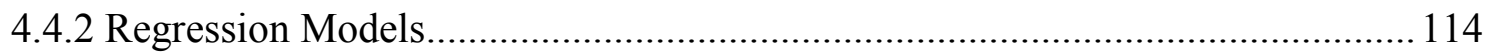

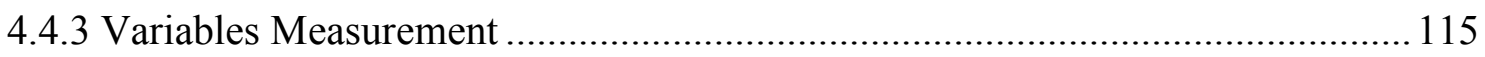

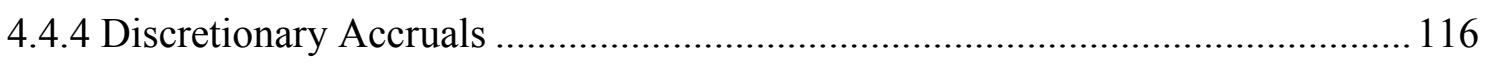

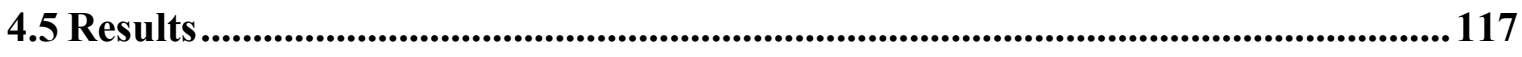

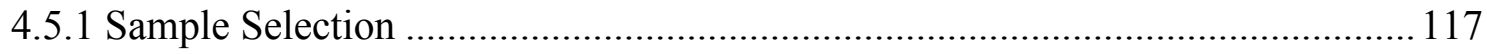

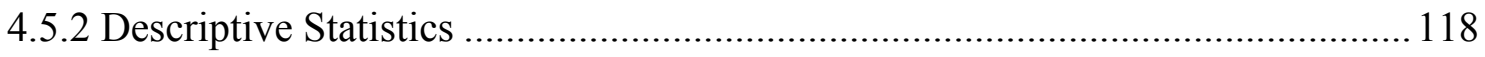

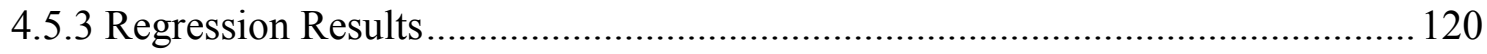

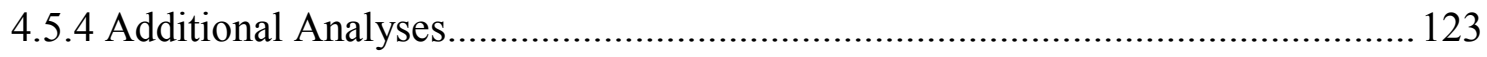

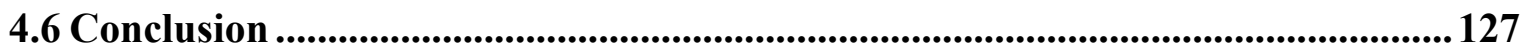

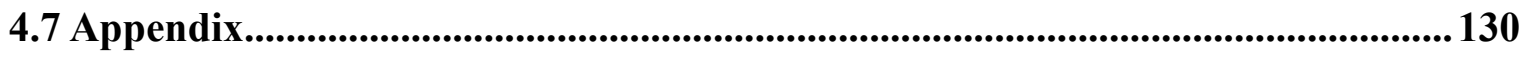




\section{THE ROLE OF CORPORATE GOVERNANCE IN SHAPING ACCRUALS}

MANIPULATION PRIOR TO ACQUISITIONS..................................................... 141

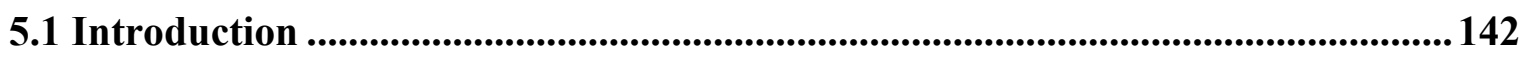

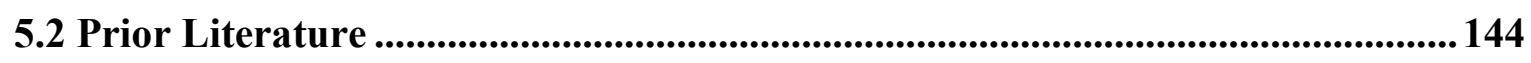

5.3 Hypothesis Development.............................................................................. 147

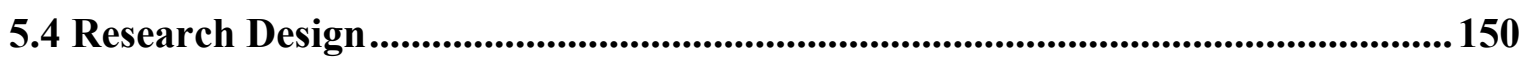

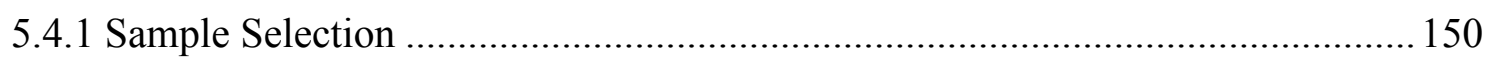

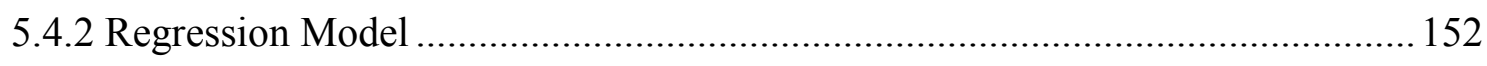

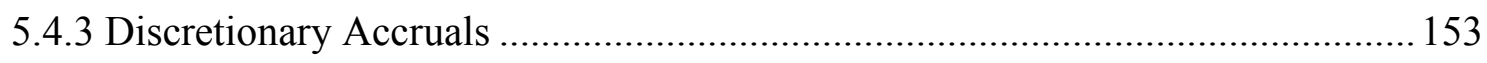

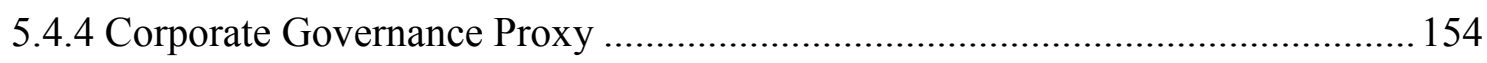

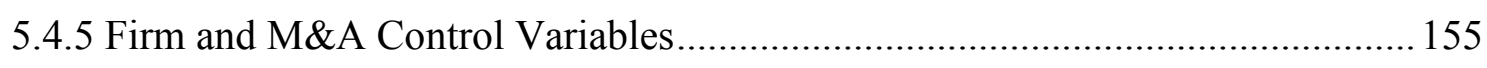

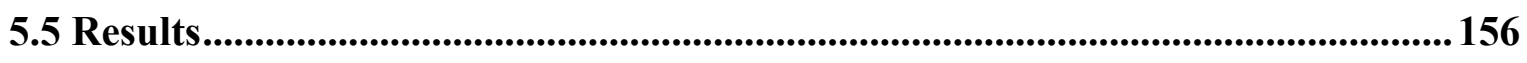

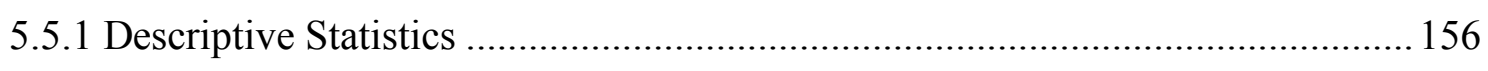

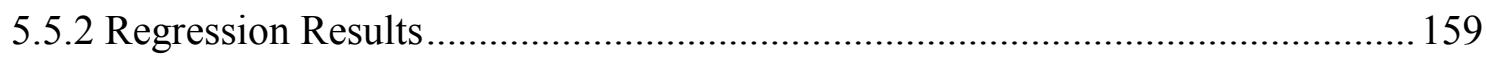

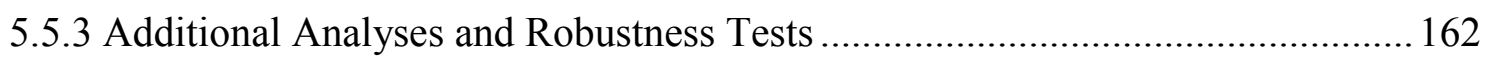

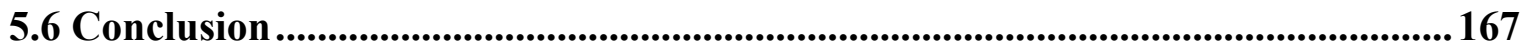

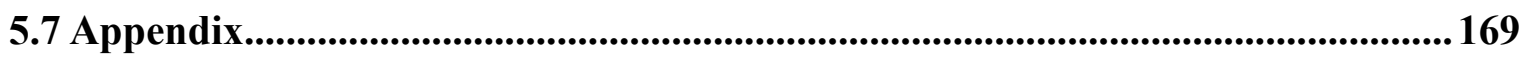

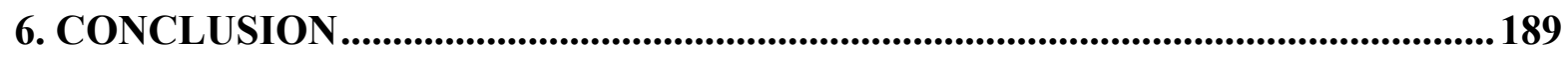

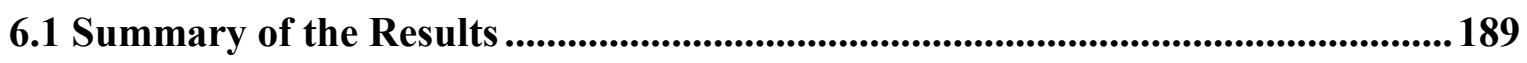

6.2 Main Limitations of the Thesis........................................................................... 191

6.3 Avenues for Future Research ............................................................................ 193

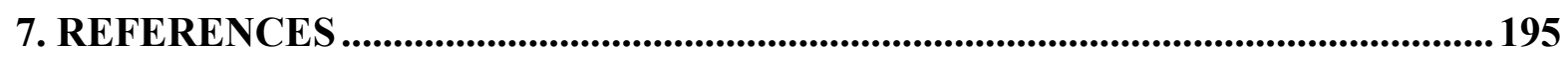

8. EIDESSTATTLICHE VERSICHERUNG ........................................................ 206

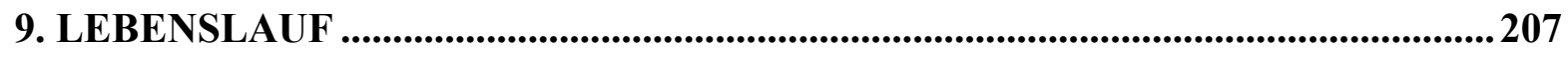




\section{LIST OF FIGURES}

- Chapter 1 -

Figure 1 - 1: Contents of the Thesis 6

Figure 1 - 2: Structure of the Thesis 10

- Chapter 2 -

Figure 2 - 1: Mean Analyses .36

\section{- Chapter 3 -}

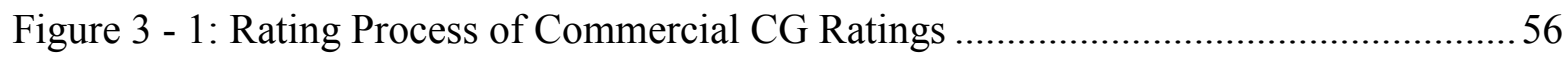

$$
\text { - Chapter } 5 \text { - }
$$

Figure 5 - 1: Time Structure of M\&A Transactions 152

Figure 5 - 2: Distribution of Median DAC around UK Stock Swap Transactions 159 


\section{LIST OF TABLES}

\section{- Chapter 2 -}

Table 2 - 1: Proxy Advisors active in Europe (non-exhaustive list) ..................................... 18

Table 2 - 2: Timeline of the Regulatory Actions in the EU ................................................. 20

Table 2 - 3: Prior Related Literature on Proxy Voting Advisory......................................... 22

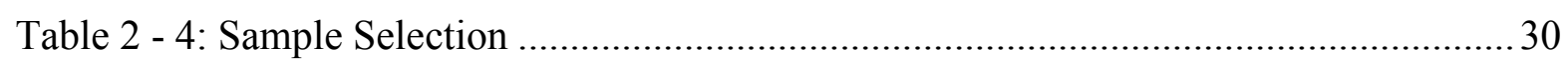

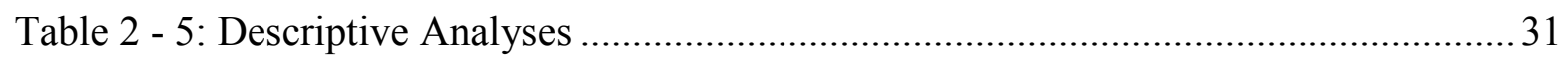

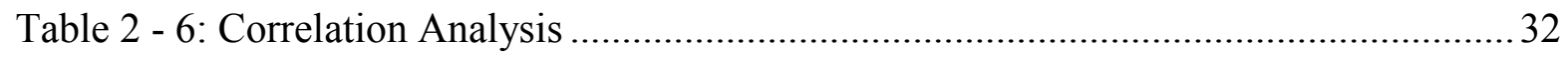

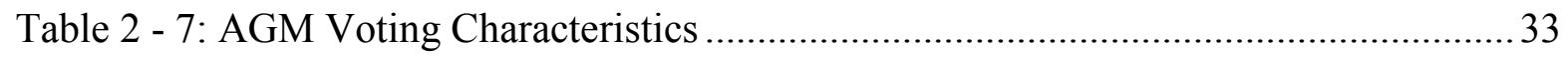

Table 2 - 8: Mean Analyses............................................................................................ 35

Table 2 - 9: Regression Results: Prediction 1 - Firm-Fixed-Effects Regressions .................. 38

Table 2 - 10: Regression Results: Prediction 2 - Probit Regressions .................................. 40

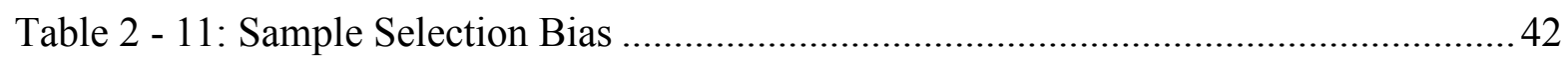

Table 2 - 12: Regression Results: Correlation vs. Causation................................................. 45

\section{- Chapter 3 -}

Table 3 - 1: Prior Literature on Corporate Governance Ratings and Firm Value ..................59

Table 3 - 2: CGQ Rating Criteria, ISS Dimensions, and Compliance .................................. 64

Table 3 - 3: Isolation of the Incremental Contribution of CG Rating Agencies ................... 65

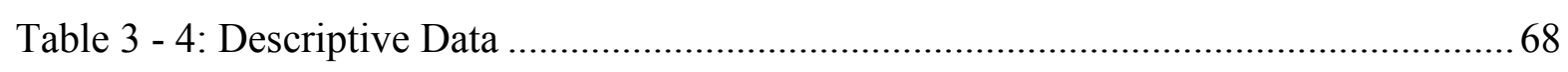

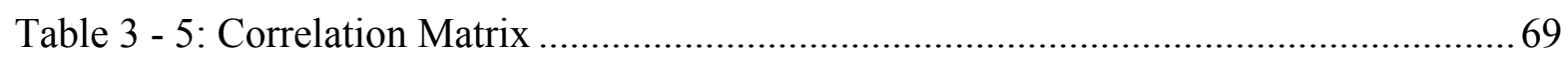

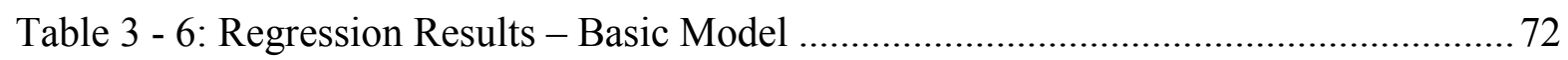

Table 3 - 7: First Stages (Selection) \& Second Stages (Endogeneity) ................................. 77

Table 3 - 8: Regression Results - Third Stage of the Three Stage Model ............................ 79

\section{- Chapter 4 -}

Table 4 - 1: Identification Strategy and Regression Samples .......................................... 113

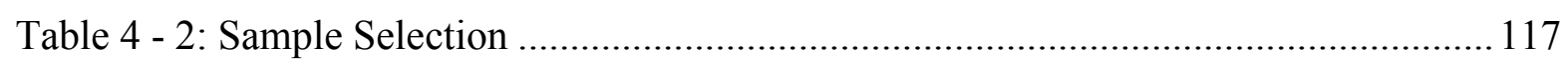

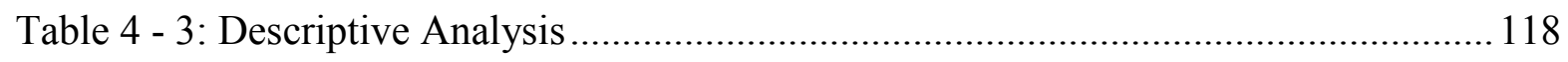

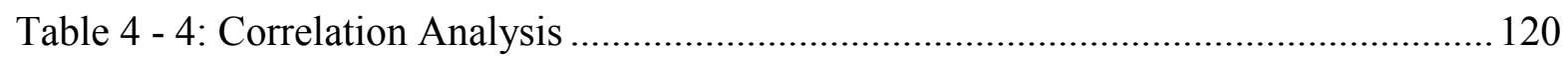

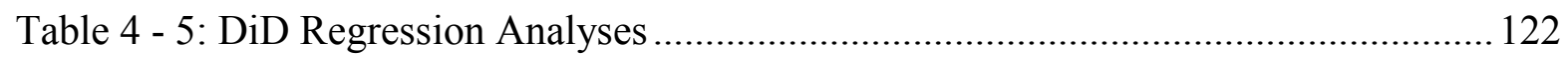

- Chapter 5 -

Table 5 - 1: Prior Literature on Corporate Governance and Earnings Management ........... 146

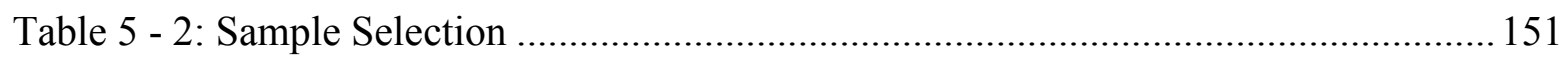




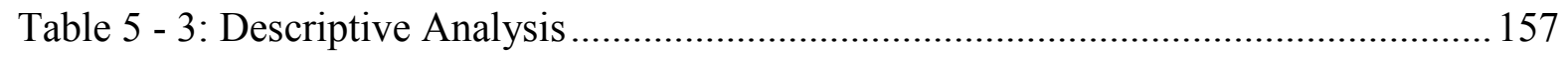

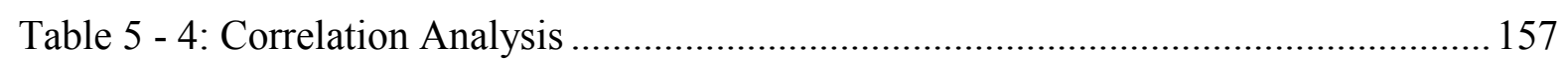

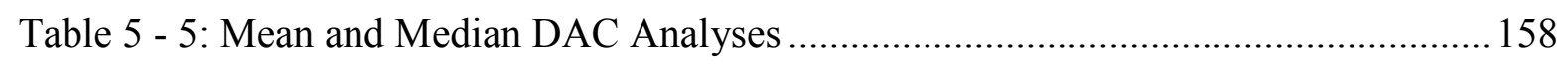

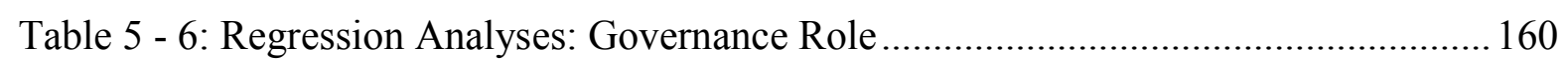

- Chapter 6 -

Table 6 - 1: Limitations and Avenues for Future Research .............................................. 192 


\section{LIST OF APPENDICES}

\section{- Chapter 2 -}

Appendix 2 - 1: Definition of Variables 49

Appendix 2 - 2: The German Business Press and ISS .50

- Chapter 3 -

Appendix 3 - 1: Definition of Variables. 86

Appendix 3 - 2: Two-Stage-Least-Squares (2SLS) \& Heckman Selection .88

Appendix 3 - 3: Basic OLS Model with restricted Sample Size. .89

Appendix 3 - 4: Basic OLS Model with alternative Firm Value Measure. 91

Appendix 3 - 5: Basic OLS Model with alternative CGI Score .93

Appendix 3 - 6: Basic OLS Model with additional Control Variables .95

Appendix 3 - 7: Economic Significance 97

Appendix 3 - 8: GOV Ratings and CGQ Subcategories .98

\section{- Chapter 4 -}

Appendix 4 - 1: Definition of Variables 130

Appendix 4 - 2: Validity of Natural Experiment.

Appendix 4 - 3: Real Earnings Management

Appendix 4 - 4: Naïve OLS Regressions (with and without Heckman Modeling).

Appendix 4 - 5: Detailed DiD Regression Analyses (w.r.t. Table 4 - 5)

\section{- Chapter 5 -}

Appendix 5 - 1: BHARs surrounding the Deal Announcement 169

Appendix 5 - 2: Sample Selection - Cash Acquirer 171

Appendix 5 - 3: Descriptive Analyses - Cash Acquirer.

Appendix 5 - 4: Governance Role - Cash Acquirer

Appendix 5 - 5: BHARs surrounding the Deal Announcement - Cash Acquirer.

Appendix 5 - 6: Sample Selection Bias

Appendix 5 - 7: Mean and Median DAC Analyses: Public Target Status. 175

Appendix 5 - 8: Governance Role - Public Target Status 175

Appendix 5 - 9: Mean and Median DAC Analysis: Different DAC Measures. 177

Appendix 5 - 10: Governance Role - Different DAC Measures . 178

Appendix 5 - 11: Governance Role - Different Governance Proxies 180

Appendix 5 - 12: Governance-Performance: Stickiness of Governance. 


\section{LIST OF APPENDICES}

Appendix 5 - 13: Governance Role - Additional Control Variables..... 183

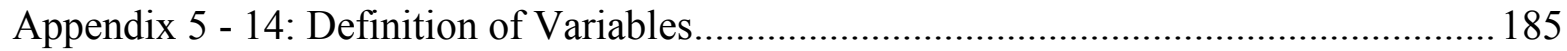


"Corporate governance is big business and, increasingly, front page news."

\section{INTRODUCTION}

\subsection{Context of the Thesis}

Based on four empirical studies, this thesis addresses and extends research on the interrelation of corporate governance, information intermediation, and earnings management. Specifically, it contributes to two main literature streams. The first is research on corporate governance advisory. The second is research on the link between corporate governance quality and earnings management. Overall, this thesis provides novel insights into the economic role of corporate governance advisors on capital markets and highlights the setting-specific nature of the governance and earnings management relationship.

\section{Corporate Governance}

In the context of this thesis, the term corporate governance denotes control and incentive mechanisms which address agency costs within a firm. Based on the classical PrincipalAgent-Theory (Jensen and Meckling, 1976), agency costs result from interest divergences and information asymmetries between shareholders (principal) and management (agent) in firms with separated ownership and control. ${ }^{2}$ Ideally, both contracting parties could negotiate a complete contract settling all tasks and duties of the agent to solve the agency conflict (Hart, 1995). Since real world contracts are incomplete, e.g., owing to transaction costs, the principal has to delegate residual control rights to the agent (Shleifer and Vishny, 1997). In addition, in firms where ownership and control are separated, the principal is not able to fully oversee the actions of the agent, e.g., the agent's discretionary allocation of the firm's profit, due to information asymmetries. Consequently, the core task of corporate governance mechanisms is to overcome the agency conflict, and thus the agency costs, resulting from interest divergences and the asymmetrical distribution of information between the principal and the agent. In their seminal paper, Shleifer and Vishny $(1997$, p. 737$)$ define corporate

\footnotetext{
${ }^{1}$ Daines et al. (2008, p. 2).

${ }^{2}$ Following Jensen and Meckling (1976), agency costs are divided into three components: residual costs, monitoring costs, and bonding costs. Monitoring costs are essentially control and incentive expenditures borne by the principal. Bonding costs serve as signaling costs occurring when the agent signals her stewardship qualities. Given optimal monitoring and bonding, the residual costs occur as a (residual) loss in welfare because interest divergence between both parties will lead at best to a second-best optimum.
} 
governance in more general terms as "the ways in which suppliers of finance to corporations assure themselves of getting a return on their investment".

Besides this traditional, Anglo-Saxon 'shareholder value' perspective, the agency relationship might differ across jurisdictions depending on the respective institutional arrangements (e.g., Schillhofer, 2003, p. 7; or more generally, see, Schmidt and Weiß, 2003, pp. 115-118). The governance debate in continental Europe, for example, is dominated by a 'stakeholder value' perspective considering agency costs induced by agency-conflicts between stakeholders (e.g., debt capital provides) and managers, or among different stakeholder groups (e.g., between minority shareholders and block holders). ${ }^{3}$ Compared to the 'shareholder value' perspective, the core task of corporate governance from a 'stakeholder value' perspective is still the alleviation of agency costs, though the configuration of the respective governance mechanisms might differ due to differences in the underlying agency conflict. In general, prior research on corporate governance focuses on mechanisms such as shareholder rights and shareholder activism features, the structure and the composition of boards (and board committees), executive compensation contracts, block holders, institutional investors, disclosure, transparency, the financial reporting system, or the market for corporate control (e.g., Bebchuk and Weisbach, 2010; Becht et al., 2005; for an overview, see Schillhofer, 2003, pp. 25-59).

\section{Earnings Management}

Among the various corporate governance mechanisms, the financial reporting process in general, and the accounting quality in particular, constitutes a specific governance mechanism. The quality of the financial reporting process can be seen both as an input as well as an output factor of the governance process (e.g., Sloan, 2001). High quality financial reporting, for example, promotes the governance process by reducing information asymmetries between the principals and the agents. In addition, corporate governance in turn is expected to increase the integrity and the reliability of the financial reporting process by implementing control and incentive mechanisms to mitigate opportunistic behavior. Specifically, corporate governance is expected to improve the financial reporting quality by constraining, among other things, earnings management.

\footnotetext{
3 Shleifer and Vishny (1997), however, consider debt capital providers (as suppliers of finance) in their governance perspective as well.
} 
Earnings management can be described as the managers' opportunistic use of accounting discretion in the financial reporting process. Managers may have incentives to alter reporting outcomes to mislead stakeholders about the firms' underlying performance or to influence contractual outcomes (Healy and Wahlen, 1999). Healy (1985), for example, shows empirically that compensation contracts induce incentives for managers to choose specific accounting procedures in order to maximize the present value of their bonus schemes. In addition, DeFond and Jiambalvo (1994) present evidence showing that managers engage in earnings management in order to avoid debt covenant violations. Since earnings management activities potentially contrast the interests of the principal, e.g., in situations where the profit allocation between the principal and the agent is influenced by earnings manipulations, earnings management induces agency costs. As governance mechanisms are designed to alleviate agency costs within a firm, they are also expected to constrain the opportunistic use of accounting discretion. In a similar vein, Dechow et al. $(1996$, p. 4) posit that "[i]nternal governance processes are established to maintain the credibility of firms' financial statements and safeguard against such behavior as earnings manipulation."

\section{Governance Advisors as Information Intermediaries}

Given the potential importance of corporate governance, governance advisory firms have vastly spread throughout the last decade (e.g., Rose, 2007). Their core business consists of fee-based governance consultancy and risk assessments via, e.g., commercial corporate governance ratings or proxy voting recommendations to institutional shareholders or other capital market participants. From an economic perspective, governance advisory firms represent information intermediaries on capital markets. Following Healy and Palepu (2002, p. 4), "information intermediaries reduce transaction costs in the capital market by providing specialized services and gathering and disseminating information“. Specifically, governance advisory firms process, enhance, and disseminate governance-related information to capital market participants in order to alleviate transaction costs (e.g., Balling et al., 2005). To the extent that governance advisory firms are able to reduce capital market participants' costs of making informed decisions (i.e., transaction costs), e.g., by providing (1) more accurate or less expensive evaluations of corporate governance quality or (2) more cost-efficient information on how to vote on shareholder meetings for a large set of portfolio firms, capital market participants potentially value the information provided by these advisors (e.g., Ertimur et al., 2013). 


\section{The Market of Governance Advisors}

These days, Institutional Shareholder Services (ISS) is considered to be the world's leading governance rating vendor and proxy advisor (ESMA, 2012). ISS markets commercial corporate governance ratings for more than 8,000 firms across 31 countries since 2002 . These commercial corporate governance ratings - based on over 60 single governance provisions are commonly available to institutional shareholders or other capital market participants via subscription packages which can result in fees of up to $\$ 100,000$ per year (Coffin and Collinson, 2005). In addition, ISS provides proxy advisory services, i.e., governance-related advisory on how to vote on annual general meetings, for over 1,700 institutional investors managing \$26 trillion in assets, including 24 of the top 25 mutual funds, 25 of the top 25 assets managers, and 17 of the top 25 public pension funds (Daines et al., 2010).

In the U.S., the business press and policy makers perceive governance advisors such as ISS as influential and powerful (Choi et al., 2010, p. 871). Delaware's former ViceChancellor Leo Strine Jr., for example, puts ISS's influence into the following words: "[P] owerful CEOs come on bended knee to Rockville, Maryland, where ISS resides, to persuade the managers of ISS of the merits of their views about issues like proposed mergers, executive compensation, and poison pills. They do so because the CEOs recognize that some institutional investors will simply follow ISS's advice rather than do any thinking of their own." (Strine, 2005, p. 688) Although at a lower frequency and in a more recent time span, the business press, academia, and policy makers in Europe and Germany have joined the discussion on the role and influence of governance advisors as well. The German press, for example, has been expanding considerably its reporting on proxy advisors at German shareholder meetings throughout the last years. Some German commentators have recently described ISS as "Mächtige Aktionärsflüsterer"4 (powerful shareholder whisperers), "einflussreichste Schattenmacht der deutschen Konzerne" (the most influential 'state within a state' among German firms), or "Rebellenführer auf Hauptversammlungen"6 (rebel leader on shareholder meetings).

However, the fact that governance advisors like ISS also provide governance advisory directly to firms raises concerns about their independence (e.g., Koeng and Ueng, 2007, p. 61;

\footnotetext{
4 Wirtschaftswoche (25/01/2012), accessible under: http://www.wiwo.de/finanzen/boerse/aktionaere-dieheimliche-macht-der-fonds/6088556.html, last accessed June 30, 2014.

5 Spiegel Online (07/05/2013), accessible under: http://www.spiegel.de/wirtschaft/unternehmen/lufthansawusste-frueh-von-widerstand-grosser-aktionaere-gegen-mayrhuber-a-898595.html, last accessed June 30, 2014.

${ }^{6}$ Wirtschaftswoche (29/07/2010), accessible under: http://www.wiwo.de/finanzen/riskmetrics-rebellenfuehrerauf-hauptversammlungen/5663966.html, last accessed June 30, 2014.
} 
Rose, 2007, pp. 891, 906; Vo, 2008, p. 17). In two recent initiatives, the European Securities and Markets Authority (ESMA) as well as the European Commission (2011, p. 15) have shared these concerns outlining potential conflicts of interest in situations "when proxy advisors also act as corporate governance consultants to investee companies”. In March 2012, ESMA released the discussion paper - "An overview of the Proxy Advisory Industry: Considerations on Possible Policy Actions" - for consultation. The purpose of this discussion paper was threefold; (1) to outline the developments of the European proxy advisory industry, (2) to raise $12 \mathrm{key}$ issues for consultation with respect to potential market failures within the proxy advisory business, and (3) to discuss potential policy options. As the consultation process neither provided clear examples of severe market failures related to the proxy advisory business nor benefits speaking in favor of an overall unregulated governance advisory business, ESMA decided not to consider any binding regulatory measures. Instead, ESMA mandated the proxy advisory business to develop a European wide code of conduct standard to increase integrity and transparency (ESMA, 2013, pp. 5-6).

\subsection{Objectives and Contribution of the Thesis}

Against the above outlined background, this thesis investigates the interrelation of corporate governance, information intermediation, and earnings management. As outlined in Figure 1 1, I address and extend two general literature streams; the stream on corporate governance advisory (e.g., Daines et al., 2010; Ertimur et al., 2013), and the stream on accrual-based earnings management and corporate governance quality (e.g., Klein, 2002; Larcker et al., 2007). The former stream of literature addresses issues such as the growth and impact of commercial corporate governance rating vendors (e.g., Rose, 2007), the role and regulation as well as the usefulness of proxy advisors (e.g., Ertimur et al., 2013; Larcker et al., 2013), or the usefulness of commercial governance ratings to investors (e.g., Daines et al., 2010). The majority of prior findings on the question whether proxy advisors or governance rating vendors are valuable for investors does not provide evidence in favor of the governance industry (e.g., Daines et al., 2010; Larcker et al., 2013). Thus, the economic vindication of these information intermediaries is still a question of debate.

Extending the literature on corporate governance advisory, this thesis provides additional insights into the role of proxy voting advisors and corporate governance rating vendors (Study $1 \& 2$ ). Specifically, it adds to the growing but U.S. dominated literature on proxy voting advisory (e.g., Cai et al., 2009; Ertimur et al., 2013; Larcker et al., 2013) and 
contributes to the current European debate on the regulation of proxy advisors (European Commission, 2011; ESMA, 2012). Given the discussion initiated by ESMA about the role of proxy advisors at European shareholder meetings, the thesis presents empirical evidence on the influence and method consistency of these advisors for a major European market (Study 1). With respect to commercially available corporate governance ratings, the thesis further provides empirical evidence on the incremental usefulness of commercial governance ratings to investors (Study 2). It complements and augments prior work by directly addressing the economic vindication of commercial corporate governance ratings. Overall, the first objective of this thesis is to contrast the usefulness of governance advisory on capital markets.

Figure 1 - 1: Contents of the Thesis

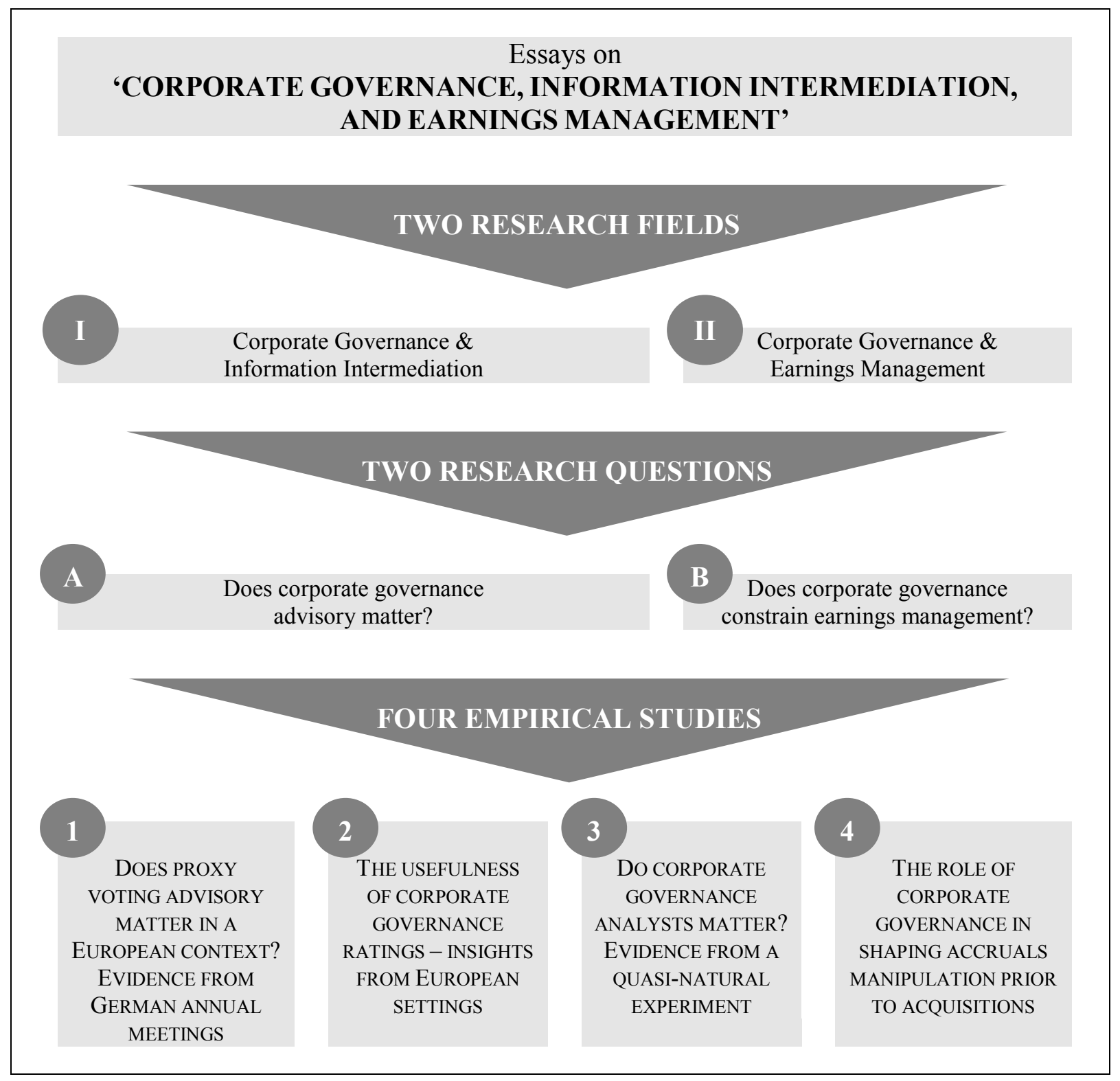


Apart from research on corporate governance advisory, a large body of finance, management, and accounting studies examines, among other things, the association between different corporate governance mechanisms (or overall governance ratings) and various firmlevel outcome variables, like operating performance, organizational performance, or financial reporting quality (e.g., Ahrens et al., 2009; Brown et al., 2011). Drawing on accounting research, previous studies have primarily focused on the relationship between corporate governance quality and financial reporting quality in general, and corporate governance quality and earnings management in particular (e.g., Dechow et al., 2010; Garcia-Meca et al., 2009). ${ }^{7}$ As outlined in section 1.1, prior accounting research assumes a constraining role of corporate governance on the opportunistic use of accounting discretion.

Extending both - research on corporate governance advisory as well as research on the link between corporate governance quality and earnings management - the thesis investigates the role of corporate governance analysts in shaping firms' information environment in general, and firms' earnings management behavior in particular (Study 3). Prior studies on financial analysts suggest that external monitors - like financial analysts - are potentially more effective in constraining earnings management than internal governance mechanisms (Yu, 2008, p. 248; Bolton et al., 2005, p. 7). These studies argue that in most cases earnings management is driven by an agency conflict between current and future shareholders rather than a conflict between managers and shareholders. Empirical evidence appears to be consistent with this claim. Prior literature documents a negative relationship between the number of financial analysts following a firm (as well as the coverage by those analysts) and earnings management (e.g., Yu, 2008; Degeorge et al., 2013a). Besides having additional empirical evidence on the role of buy-side analysts and bond analysts (Cheng et al., 2006; De Franco et al., 2009), as well as on the (non-financial) information processing of financial analysts (Orens and Lybaert, 2010; Bhat et al., 2006; Byard et al., 2006; Asare et al., 2011), previous literature has been silent on the coverage effects of corporate governance analysts and their potential interactions with financial analysts, investors, or managers. Consequently, the second objective of this thesis is to highlight the role of (non-financial) corporate governance analysts. To that end, the thesis provides empirical evidence on the potential economic consequences of governance analyst coverage.

\footnotetext{
7 Typical dimensions of financial reporting quality are earnings quality (e.g., earnings timeliness and conservatism, earnings management, persistence, predictability, or value relevance), disclosure quality, or transparency (e.g., Francis et al., 2004).
} 
To explicitly address and extend research on earnings management and governance quality, the thesis finally examines in detail the link between corporate governance quality and accrual-based earnings management (Study 4). Although prior accounting research assumes - either explicitly or implicitly - a constraining role of corporate governance on accruals manipulation $^{8}$ (e.g., Dechow et al., 1996), the empirical evidence so far is rather mixed (e.g., Brown et al., 2011; Dechow et al., 2010; Larcker et al., 2007). Therefore, the third objective of the thesis is to provide a possible explanation for this inconclusive evidence by highlighting the setting specific-nature of the earnings management and corporate governance relationship. Specifically, the thesis provides empirical evidence on the relationship between accruals manipulation and corporate governance in a specific-setting, i.e., stock swap M\&A transactions, in which prior literature documents income-increasing accruals manipulations, and in which invested shareholders of the acquiring firm might benefit from managerial discretion in the accrual process.

\subsection{Structure of the Thesis}

As outlined in Figure $1-2$, the thesis is structured as follows: Chapter 1 outlines the motivation and the structure of the thesis. The following four chapters, 2 to 5 , present the four empirical studies. The last chapter concludes.

Chapter 2. Does proxy voting advisory matter in a European context? Evidence from German annual meetings: The first study of the thesis investigates the influence and the consistency of proxy voting recommendations for a major European market (Study 1). To that end, it exploits a sample of 1,664 annual general meeting agenda items and the corresponding proxy voting recommendations issued by ISS for the German proxy season 2010. The results indicate that negative ISS voting recommendations coincide with an $8.5 \%$ reduction of shareholder support. This reduction is even more pronounced for firms with high free float, low voting turnout, and high ISS client base. With respect to the economic significance, ISS voting recommendations, however, potentially affect voting outcomes at a lower level as compared to prior U.S. evidence (e.g., $8.5 \%$ to $19 \%$ and $26 \%$ as documented by Cai et al., 2009 and Ertimur et al., 2013, respectively). In addition and in contrast to recent U.S.

\footnotetext{
${ }^{8}$ In essence, accruals are the difference between GAAP earnings and cash from operations. Discretionary accruals are in turn accrual components which are subject to the manager's judgment due to accounting discretions (e.g., IAS 38.43, recognition of intangible assets: accounting discretion in the process of assessing the fulfillment of the recognition criteria in paragraph 38.57) or accounting choices (e.g., IAS 40.30, measurement after recognition for investment properties: accounting choice between the cost model or the fair value model) in the respective accounting standards.
} 
findings, the results further suggest that ISS recommendations significantly correlate with ISS's commercially available corporate governance ratings (GRId). Specifically, ISS's recommendations against the election of supervisory board members (against the remuneration system) are significantly correlated with ISS's evaluations of the corresponding board quality (of the remuneration system's quality). These findings highlight potential method consistency with respect to ISS's underlying governance perceptions. Overall, this study extends the growing but U.S. dominated literature on proxy voting advisory and contributes to the current European debate on the regulation of proxy advisors. Specifically, this study adds to the discussion initiated by ESMA about the role of proxy advisors at European shareholder meetings by providing empirical evidence on the influence and method consistency of those advisors for a major European market.

Chapter 3. The usefulness of corporate governance ratings - insights from European settings: Extending the perspective of the first study, the second study of the thesis provides insights into the usefulness of governance advisory on capital markets (Study 2). Specifically, it investigates the power of corporate governance ratings in explaining firm value, and augments prior work by examining in detail the incremental value created by the rating agency's activities of translating public and private information into commercial ratings. To that end, it is the first study to shed light on the incremental usefulness of a governance agency's proprietary technology. Using data provided by ISS for the UK and the German markets, the analyses indicate that, in line with prior work, commercial ratings are positively associated with firm value. However, isolating the incremental contribution of the rating agency, the study finds no additional explanatory power relative to a naïve rating that is constructed from the observable, publicly available inputs which ISS uses. This suggests that the rating agency does not create value by assembling a rating from observable data using proprietary technology, and supplementing private information. These findings put into question the incremental usefulness of the rating agencies' information processing activities, indicating that the core competitive advantage of these institutions rather lies in the activity of collecting publicly available governance data, creating transaction cost savings for investors, or other, hitherto unexplored factors.

Chapter 4. Do corporate governance analysts matter? Evidence from a quasi-natural experiment: Addressing both - research on governance advisory as well as research on the relationship between governance and earnings management - the third study of the thesis investigates the role of corporate governance analysts in shaping firms' information 
environment in general, and firms' earnings management behavior in particular (Study 3).

Figure 1 - 2: Structure of the Thesis

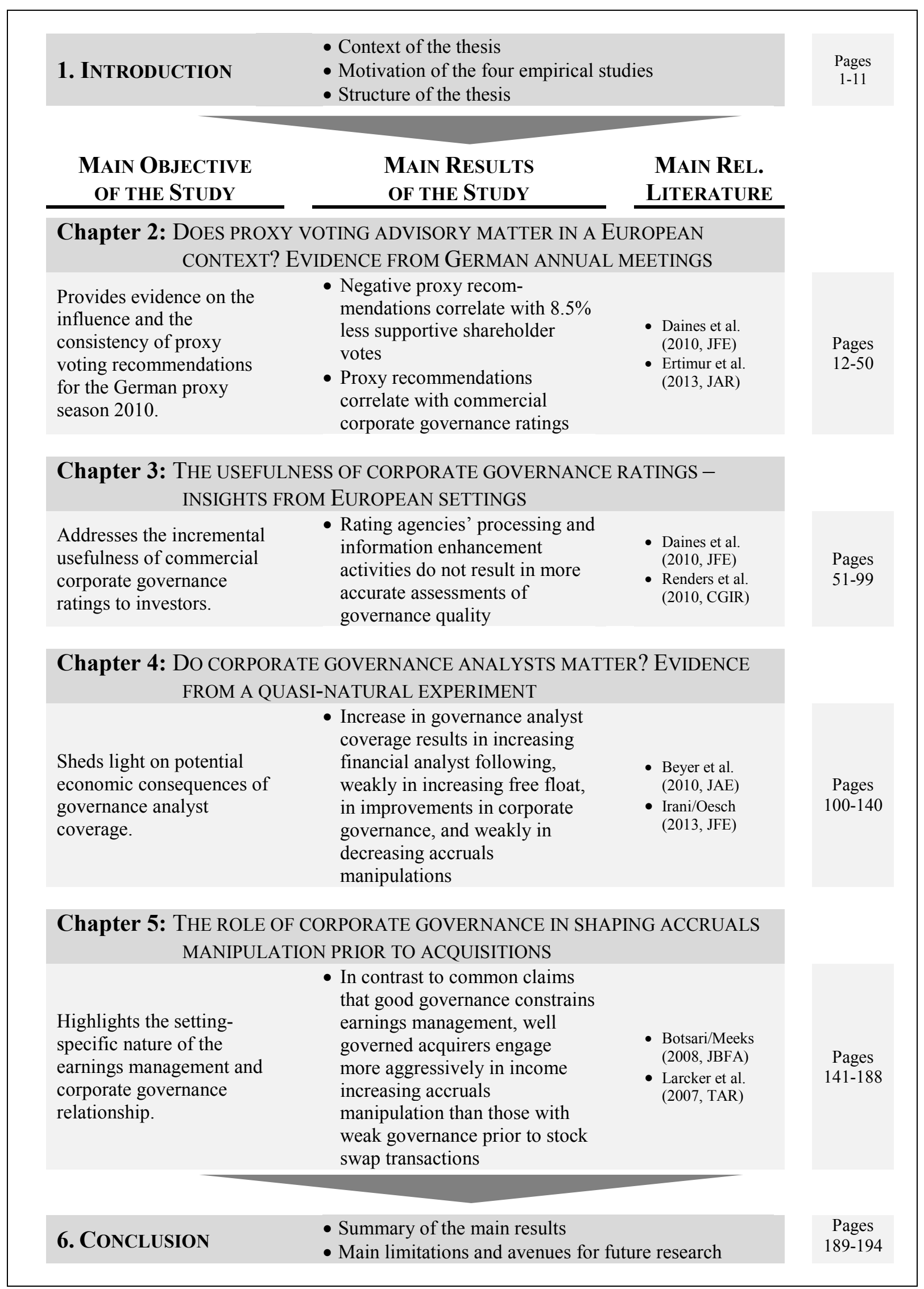


Specifically, this study examines potential economic consequences of governance analyst coverage by focusing on two different groups (financial analysts and investors) as well as on two firm-level mechanisms (corporate governance quality and earnings management) which are potentially affected by the presence of governance analysts. Using a quasi-natural experiment that exploits an exogenous shock in the UK governance analyst coverage, this study finds that an increase in governance analyst coverage results in increasing analyst following, weakly in increasing free float, in improvements in firm-level corporate governance, and weakly in decreasing accruals manipulations. These findings suggest that financial analysts, investors, and managers respond to changes in governance analyst coverage. Overall, the findings are consistent with the notion that governance analysts serve as economically meaningful information intermediaries by enhancing a firm's information environment and by promoting external monitoring to managers

Chapter 5. The role of corporate governance in shaping accruals manipulation prior to acquisitions: Extending the perspective of the third study, the last study of the thesis directly examines the relationship between corporate governance and earnings management (Study 4). In particular, it highlights the setting-specific nature of the earnings management and corporate governance relationship. In doing so, this study examines whether the acquirer's corporate governance quality affects the acquirer's earnings management behavior prior to share-based M\&A transactions. As accruals manipulation prior to share deals is potentially in the interests of the acquirer's shareholders, this setting offers - in contrast to the stated assumptions of prior literature - an alternative view on the effects of corporate governance, namely that good governance potentially promotes earnings management instead of constraining it. Using stock swap transactions with public acquirers originating from the UK between the years 1998 and 2011, the results confirm recent findings of Botsari and Meeks (2008) that acquirers on average manipulate accruals upward in the period leading up to the transactions. However, and contrary to common claims that strong corporate governance constrains accruals manipulation, the analyses of the period specific earnings management behavior prior to share deals suggest that acquirers with strong governance engage more aggressively in income-increasing accruals manipulation than those with weak governance. This finding is consistent with the notion that corporate governance incentivizes managerial actions in the interests of firms' shareholders. 


\title{
2. DOES PROXY VOTING ADVISORY MATTER IN A EUROPEAN CONTEXT? EVIDENCE FROM GERMAN ANNUAL MEETINGS
}

\author{
Nico Lehmann ${ }^{9}$ \\ Working Paper ${ }^{10}$, Georg-August-Universität Göttingen
}

\begin{abstract}
This paper investigates the influence and the consistency of proxy voting recommendations for a major European market. In doing so, it exploits a sample of 1,664 annual general meeting (AGM) agenda items and the corresponding proxy voting recommendations issued by Institutional Shareholder Services (ISS) for the German proxy season 2010. The results indicate that negative ISS voting recommendations coincide with an $8.5 \%$ reduction of shareholder support. This reduction is even more pronounced for firms with high free float, low voting turnout, and high ISS client base. In addition and in contrast to recent U.S. findings, the results further suggest that ISS recommendations significantly correlate with ISS's commercially available corporate governance ratings (GRId). Specifically, ISS's recommendations against the election of supervisory board members (against the remuneration system) are significantly correlated with ISS's evaluations of the corresponding board quality (of the remuneration system's quality). These findings highlight a potential method consistency with respect to ISS's employed governance perceptions. Overall, this paper extends the growing but U.S. dominated literature on proxy voting advisory and contributes to the current European debate on the regulation of proxy advisors. Specifically, this paper complements the discussion initiated by the European Securities and Markets Authority (ESMA) about the role of proxy advisors at European AGMs by providing first descriptive evidence on the influence and method consistency of these advisors for a major European market.
\end{abstract}

JEL Classification: G24, G30

Keywords: Information intermediaries, proxy voting advisory, corporate governance

Acknowledgment: For valuable comments, I am very grateful to my dissertation adviser Jörg-Markus Hitz.

\footnotetext{
${ }^{9}$ Georg-August-Universität Göttingen, Faculty of Economic Sciences, Chair of Accounting and Auditing, Platz der Göttinger Sieben 3, 37073 Göttingen, Germany.

${ }^{10}$ First version of the working paper: March 2014. This version: July 2014.
} 


\subsection{Introduction}

This paper addresses the role of proxy voting advisors for a major European market in two respects. First, it examines the influence of these advisors in shifting voting outcomes at German annual general meetings (AGM). Second, it investigates the consistency of their voting recommendations with respect to the employed governance perceptions. To that end, this paper extends the growing but U.S. focused literature on proxy voting advisory (e.g., Cai et al., 2009; Ertimur et al., 2013; Larcker et al., 2013) and contributes to the current European debate on the regulation of proxy advisors (European Commission, 2011; ESMA, 2012).

Proxy advisors facilitate and support one of the key governance instruments of shareholders, namely the shareholders' vote on AGMs (ESMA, 2012, p. 9). Specifically, they issue recommendations and research on how to vote on AGM agenda items. In the case of institutional investors with diversified portfolios covering firms from different countries with different governance traditions, proxy advisors are expected to improve the voting process of these investors by lowering potential information and monitoring costs (ESMA, 2012, p. 9).

Prior U.S. research suggests that "vote against" recommendations issued by Institutional Shareholder Services (ISS) - the most influential advisor worldwide - correlate with a voting dissent of up to $26 \%$ of shareholder votes (e.g., Ertimur et al., 2013). Moreover, a recent U.S. study casts doubts on the method consistency of ISS by documenting that ISS's voting recommendations are only weakly correlated with its commercially available governance ratings (Daines et al., 2010, pp. 455-460). However, whether these results translate to a continental European setting is an open question. In contrast to the U.S., the German market is characterized by a stakeholder model of corporate governance in which, among other things, codetermination, large shareholders, and banks play important roles (e.g., Goergen et al., 2008). Specifically, compared to the U.S., the German capital market exhibits a rather low degree of dispersed ownership and institutional (U.S.) holdings (e.g., Cziraki et al., 2010, p. 748), and lacks experience with proxy voting advisory (ESMA, 2012, p. 16). Compared to the long-lasting public debate about the role and influence of proxy voting advisory in the U.S. (e.g., Center on Executive Compensation, 2011, pp. 14-21), similar issues have received rather little attention in Germany. In recent years, however, the business press, academia, and regulators in Germany as well as in continental Europe have been adding proxy voting advisory to their agendas. The German press, for example, has been expanding considerably 
its reporting on proxy advisors at German shareholder meetings throughout the last years. ${ }^{11}$ Some German commentators have recently described ISS as "Mächtige Aktionärsflüsterer"12 (powerful shareholder whisperers), "einflussreichste Schattenmacht der deutschen Konzerne"13 (the most influential 'state within a state' among German firms), or "Rebellenführer auf Hauptversammlungen""14 (rebel leader on shareholder meetings).

In addition, the European Commission and the European Securities and Markets Authority (ESMA) have recently raised concerns about the role and influence of proxy voting advisors at European AGMs. In the consultation process of its discussion paper, ESMA (2012, p. 39), for example, has invited comments on the questions (1) whether proxy advisors have a significant impact on the voting results at European AGMs and (2) whether improvements should be made with respect to transparency and methodology to provide more reliable and independent voting recommendations. Overall, the feedback during the consultation period has highlighted that - despite anecdotal evidence - empirical evidence on the role and influence of proxy advisors at European AGMs is not available (ESMA, 2013). Accordingly, the main purpose of this study is to contribute to the discussion initiated by European regulators and to provide first descriptive evidence on the influence of proxy advisors as well as on the method consistency of their voting recommendations for a major European market.

Based on a German sample of 1,664 AGM voting items (185 individual firms) and the corresponding proxy voting recommendations issued by ISS for the year 2010, I find that ISS proxy voting recommendations potentially affect voting outcomes. However, three factors appear to play a crucial role both at an economic and a statistical level: the client base of ISS, the voting turnout at AGMs, and the ownership concentration. Specifically, a "vote against" recommendation issued by ISS significantly correlates with on average $8.5 \%$ fewer supportive shareholder votes. This correlation is even more pronounced when considering voting items with high ISS client base (11.21\%), with low voting turnout $(11.59 \%)$, and high free float (11.44\%). When examining a subsample of firms with high client base, negative ISS recommendations even correlate with $16.32 \%$ and $16.11 \%$ less supportive shareholder votes

\footnotetext{
${ }^{11}$ See Appendix 2 - 2.

12 Wirtschaftswoche (25/01/2012), accessible under: http://www.wiwo.de/finanzen/boerse/aktionaere-dieheimliche-macht-der-fonds/6088556.html, last accessed June 30, 2014.

13 Spiegel Online (07/05/2013), accessible under: http://www.spiegel.de/wirtschaft/unternehmen/lufthansawusste-frueh-von-widerstand-grosser-aktionaere-gegen-mayrhuber-a-898595.html, last accessed June 30, 2014.

${ }^{14}$ Wirtschaftswoche (29/07/2010), accessible under: http://www.wiwo.de/finanzen/riskmetrics-rebellenfuehrerauf-hauptversammlungen/5663966.html, last accessed June 30, 2014.
} 
for voting items with low voting turnout and high free float, respectively. In addition, sensitivity analyses based on (1) a subsample of non-routine items ${ }^{15}$ and (2) on a subsample which considers alternative voting recommendations issued by the second largest German association of shareholders as a benchmark of publicly available information support my original findings.

To address - in a second step - the consistency of ISS voting recommendations, I follow Daines et al. (2010) and compare ISS voting recommendations with another product marketed by ISS, namely ISS's commercial corporate governance ratings (GRId). To that end, I expect that high (low) correlations between the two commercially available products indicate a rather high (low) consistency with respect to the governance standards employed by ISS. High method consistency might in turn increase accountability and transparency of the advisory services. Since ISS governance ratings (GRId ratings) are not available for all sample firms, I base the analysis on a subsample of firms (918 recommendations based on 92 individual firms). My results suggest that ISS voting recommendations are significantly correlated with ISS commercial corporate governance ratings. Specifically, ISS's recommendations against the election of supervisory board members (against compensation issues) are significantly correlated with ISS's evaluations of the corresponding board quality (the remuneration system's quality). For example, the predicted probability of receiving a "vote against" recommendation by ISS on director election (compensation) proposals is $58.19 \%$ (66.98\%) and 8.63\% (1.29\%) for firms with the lowest and the highest board (compensation) score, respectively. In addition, a "vote against" recommendation by ISS significantly correlates with ISS's overall commercially available governance ratings. For an increase from the lowest to the highest rated firm, the probability of receiving a "vote against" recommendation by ISS on all management proposals is reduced by more than 20 percentage points. This is even more pronounced - with a reduction of over 50 percentage points - when considering only non-routine management proposals.

In sum, my findings shed light on the influence as well as the consistency of ISS proxy voting recommendations at German AGMs. Specifically, they suggest that - despite differences in the institutional arrangement between the U.S. and Germany - proxy voting advisors might play an influential role at German AGMs as well. With respect to the

\footnotetext{
${ }^{15}$ In contrast to routine items, opinions and best practice on how to vote on non-routine items, e.g., significant business decisions or remuneration packages, might differ among shareholders and proxy advisors (ESMA, 2012, p. 19).
} 
economic significance, ISS voting recommendations, however, correlate with voting outcomes at a lower level (e.g., $8.5 \%$ to $19 \%$ and $26 \%$ as documented by Cai et al., 2009 and Ertimur et al., 2013, respectively). In addition and in contrast to Daines et al. (2010), my findings reveal significant correlations between two different commercial products which are marketed by ISS, i.e., ISS proxy voting recommendations and ISS corporate governance ratings. These findings suggest that the employed governance perception of ISS is potentially consistent across its different commercially available products. Overall, the findings of this study contribute to the discussion initiated by European regulators and provide first descriptive evidence on the influence of proxy advisors as well as on the method consistency of their voting recommendations for a major European market.

The remainder of the paper is structured as follows: Section 2.2 provides background information on the European proxy advisory business and reviews the related literature. Section 2.3, 2.4, and 2.5 introduce the empirical predictions, the research design, and the results, respectively. The last section concludes.

\subsection{Background}

\subsubsection{The Economic Role of Proxy Advisors}

Proxy voting advisors, such as ISS, provide advisory services to institutional investors. Most importantly, they issue recommendations on how to vote on AGMs' agenda items. In addition, they offer a range of services, e.g., governance-related research, customized voting guidelines for investors, or the whole voting logistics. In some cases, they even exercise the voting decision in their own discretion on behalf of the investors (Choi et al., 2010, p. 871). From an economic perspective, proxy advisors facilitate and support one of the key governance instruments of shareholders, namely the shareholders' vote on AGMs to exercise their ownership rights (ESMA, 2012, p. 9). Following Ertimur et al. (2013, p. 5), proxy advisors serve as information intermediaries that collect, process, and disseminate governance-related information in order to reduce the capital market participants' costs of making informed decisions (i.e., transaction costs). Specifically, in the case of institutional investors with large and diversified portfolios covering hundreds of firms from different countries with different governance traditions, proxy advisors are expected to improve the voting process of these investors by lowering potential information and monitoring costs (ESMA, 2012, p. 9). 


\subsubsection{German Shareholder Meetings and Proxy Advisory}

In the German two-tier system, AGMs are usually convened by the management board $(\S 121$ (2) AktG). In contrast to the U.S. system, management board and supervisory board together set the agenda of the AGM ( $\$ 123$ (1) AktG). In doing so, they pose so-called management proposals which must be publicly available at the firm's website at least 30 days prior to the meeting ( $\S 124 \mathrm{a} \mathrm{AktG})$. If shareholders' stakes in a firm exceed a specific quorum (5\% or EUR 500,000.00 of the nominal share capital), they are entitled to convene a meeting or to submit own proposals to the agenda $(\S 122(2,3) \mathrm{AktG})$. At the meeting, shareholders have the right to vote on management (and shareholder) proposals. According to the German Stock Corporation Law (AktG), shareholders have to vote, among other things, on proposals pertaining to the approval of dividends, the discharges of the management and supervisory board members, the nominations of supervisory board members, the appointment of the statutory auditor, the amendments of the articles of association, and capital-related issues such as the creation of capital pools or share repurchase programs ( $\S 119 \mathrm{AktG}$ ). Based on the agenda of the meeting, proxy voting advisors release different fee-based services (e.g., recommendations on how to vote on the respective proposals) to institutional investors or other capital market participants prior to the meeting.

\subsubsection{The European Proxy Advisory Business}

The first proxy advisory firms (i.e., ISS in the U.S. and PIRC in the UK) were established in the 1980s (ESMA, 2012, pp. 10-11). In subsequent years, and especially in the 2000s, many new proxy advisors have been established both in the U.S. (e.g., Glass Lewis, Proxy Governance, or Egan-Jones Proxy Services) and in Europe (e.g., Proxinvest in France, Manifest in the UK, or IVOX in Germany). ${ }^{16}$ Nowadays, ISS - a former subsidiary of RiskMetrics Group and MSCI - is considered as the leading proxy advisor in the world (ESMA, 2012, p. 10). ${ }^{17}$ According to Daines et al. (2010, p. 439), ISS provides proxy voting services for over 1,700 institutional investors managing \$ 26 trillion in assets, including 24 of the top 25 mutual funds, 25 of the top 25 assets managers, and 17 of the top 25 public pension funds. In the U.S., the business press and policy makers perceive especially ISS and Glass

\footnotetext{
${ }^{16}$ The increase in the US market in the 2000s is especially related to the 2003 SEC regulation on mutual funds voting practice (ESMA, 2012, p. 9).

${ }^{17}$ In particular, U.S. market shares are distributed as follows: ISS (61\%), Glass Lewis (36\%), and remaining proxy advisors, like Proxy Governance or Egan-Jones Proxy Services (3\%) (ESMA, 2012, p. 10).
} 
Lewis (as the second largest U.S. proxy advisor) as influential and powerful (Choi et al., 2010, p. 871). ${ }^{18}$ In contrast to the U.S., proxy advisory in Europe is small (in terms of coverage and turnover) and still developing (ESMA, 2012, p. 16). In recent years, however, the business press, academia, and policy makers in Europe and Germany have joined the discussion about the role and influence of proxy advisors. Based on the ESMA consultation paper (ESMA, 2012, pp. 9-15), Table 2 - 1 summarizes the main players in the market.

Table 2 - 1: Proxy Advisors active in Europe (non-exhaustive list) ${ }^{19}$

\begin{tabular}{|c|c|}
\hline ADVISORS & BRIEF DESCRIPTION \\
\hline ISS (U.S.) & $\begin{array}{l}\text { - Founded in 1985, ISS is a subsidiary of MSCI and considered as the leading proxy advisor in } \\
\text { the world (with over } 1,700 \text { clients who have } \$ 26 \text { trillion in assets under management). It } \\
\text { provides a wide range of governance services, including global proxy voting advisory, } \\
\text { commercial corporate governance ratings, and consulting services to corporate issuers. ISS is } \\
\text { incorporated in Delaware and registered as an SEC regulated investment adviser. It has } 16 \\
\text { offices (and over } 600 \text { employees) around the world with European-based offices in London, } \\
\text { Brussels, and Paris. }\end{array}$ \\
\hline $\begin{array}{l}\text { Glass, } \\
\text { Lewis \& } \\
\text { Co. (U.S.) }\end{array}$ & $\begin{array}{l}\text { - Founded in } 2003 \text {, Glass Lewis is perceived as the second largest proxy advisor worldwide } \\
\text { (with over } 900 \text { clients who have } \$ 15 \text { trillion in assets under management). Glass Lewis is a } \\
\text { portfolio firm of The Ontario Teachers' Pension Plan Board (OTPP) and Alberta Investment } \\
\text { Management Corp. (AIMCo), which are also clients of Glass Lewis. It provides governance } \\
\text { services, including proxy advisory and financial transactions / portfolio research, but } \\
\text { excluding governance ratings and consulting services to corporate issuers. Glass Lewis is } \\
\text { incorporated in Delaware but not registered as an SEC regulated investment adviser. It has } \\
\text { five offices (with over } 300 \text { employees) around the world with a European-based office in } \\
\text { Limerick, Ireland (since 2011). }\end{array}$ \\
\hline $\begin{array}{l}\text { Proxinvest } \\
\text { (FR) }\end{array}$ & $\begin{array}{l}\text { - Founded in 1995, Proxinvest provides proxy advisory services for all firms in the MSCI } \\
\text { Europe Index and FTSE Eurofirst } 300 \text {. It does not provide any consulting to corporate issuers. } \\
\text { Since } 2010 \text {, the Swiss pension funds foundation Ethos is a major shareholder of Proxinvest } \\
\text { (with a stake of } 20 \% \text { ). Proxinvest is a shareholder and founding member of Expert Corporate } \\
\text { Governance Service (ECGS), which is a joint venture of different proxy advisors. }\end{array}$ \\
\hline PIRC (UK) & $\begin{array}{l}\text { - Founded in 1986, PIRC (Pension \& Investment Research Consultants) provides governance } \\
\text { services to institutional investors (who have over } £ 1.5 \text { trillion in assets under management). } \\
\text { These governance services include proxy advisory, governance and CSR consultancy, but } \\
\text { explicitly exclude any consulting services to corporate issuers. PIRC is regulated by the UK } \\
\text { Financial Services Authority (FSA). }\end{array}$ \\
\hline $\begin{array}{l}\text { Manifest } \\
\text { (UK) }\end{array}$ & $\begin{array}{l}\text { - Founded in 1995, Manifest provides global proxy voting advisory (coverage of over } 80 \\
\text { markets) and governance services to institutional investors (who have over } £ 3 \text { trillion in } \\
\text { assets under management). It has two offices (with over } 40 \text { employees), which are located in } \\
\text { the UK and Australia. In 2014, Manifest joined ECGS. }\end{array}$ \\
\hline
\end{tabular}

\footnotetext{
${ }^{18}$ Delaware's former Vice-Chancellor Leo Strine Jr. (2005, p. 688), for example, describes this as follows: "[P] owerful CEOs come on bended knee to Rockville, Maryland, where ISS resides, to persuade the managers of ISS of the merits of their views about issues like proposed mergers, executive compensation, and poison pills. They do so because the CEOs recognize that some institutional investors will simply follow ISS's advice rather than do any thinking of their own. ISS has been so successful that it now has a California rival, Glass Lewis."

19 Based on ESMA (2012, pp. 11-12), Center on Executive Compensation (2011, pp. 28-41), the advisors' responses on the ESMA consultation, and the advisory firms' websites.
} 
Table 2 - 1: Proxy Advisors active in Europe (non-exhaustive list) (continued)

\begin{tabular}{|c|c|}
\hline ADVISORS & BRIEF DESCRIPTION \\
\hline $\begin{array}{l}\text { IVOX } \\
\text { (GER) }\end{array}$ & $\begin{array}{l}\text { - Founded in 2006, IVOX provides proxy voting advisory and governance research (i.e., } \\
\text { governance ratings) to over } 35 \text { clients / institutional investors (who have } € 1.9 \text { trillion in assets } \\
\text { under management). It does not provide any consulting services to corporate issuers. IVOX } \\
\text { has offices in Germany (headquarter in Karlsruhe), France, and England. IVOX is owned by } \\
\text { its founders (among other things by its current director Alexander Juschus) and a Swiss } \\
\text { foundation. As IVOX does not develop own proxy voting guidelines (their recommendations } \\
\text { are always based on customized guidelines), "it is not unusual that IVOX provides five } \\
\text { different recommendations for the same meeting." }{ }^{20}\end{array}$ \\
\hline ECGS (FR) & $\begin{array}{l}\text { - Founded in 2001, ECGS (Expert Corporate Governance Service) is a joint venture of six } \\
\text { European-based proxy advisors (i.e., DSW from Germany, Ethos from Switzerland, } \\
\text { Shareholder Service from the Netherland, Frontis Governance from Italy, Manifest from UK, } \\
\text { and Proxinvest from France) and two non European-based advisors (Groupe Investissement } \\
\text { Responsable Inc. from Canada and SIRIS from Australia). }{ }^{21} \text { ECGS provides proxy voting } \\
\text { advisory and governance research to institutional investors. It does not provide any consulting } \\
\text { services to corporate issuers. }\end{array}$ \\
\hline
\end{tabular}

\subsubsection{Regulatory Initiatives in Europe}

The proxy advisory industry in Europe is virtually unregulated (ESMA, 2012, p. 5). ${ }^{22}$ As this industry is growing in influence and prominence in Europe due to increasing (foreign) institutional holdings and dispersed ownership among large and listed European firms, European regulators have been recently adding proxy voting advisory to their agendas. In particular, concerns arise, especially among issuers (reviewed firms), that only few proxy advisors dominate the business (with actually one dominant player, namely ISS), that these advisors operate in a virtually unregulated environment, and that some investors blindly follow the recommendations issued by them (ESMA, 2012, p. 9). In addition, potential conflicts of interests (e.g., in situation where proxy advisors also provide services to corporate issuers) and low transparency levels are seen critically by issuers and regulators (ESMA, 2012, p. 9).

\footnotetext{
${ }^{20}$ See, IVOX response on the ESMA 2012 discussion paper.

${ }^{21}$ See 2014 ECGS Guidelines for Public (accessible under: http://ecgs.com/node/66, last accessed June 30, 2014).

${ }^{22}$ Specifically, there exist no European-wide regulatory measures which address directly proxy voting advisors. However, on member state level, there are some policy recommendations which address directly/indirectly the proxy advisory industry, e.g., the UK FRC Stewardship Code Principle 1 \& 6 from 2012 and the French AMF Recommendation No. 2011-06 (ESMA, 2012, pp. 29-30). U.S. proxy advisors are normally regulated under the Investment Adviser Act from 1940 (ESMA, 2012, p. 27). Under this regulation, proxy advisors have to comply with certain fiduciary obligations and have to meet minimum disclosure standards. Depending on the services provided, not all advisors, however, are required to register as investment advisors under the Adviser Act. In 2010, the SEC released a concept paper on the U.S. proxy voting system to review the role and influence of proxy advisors in the US and to discuss potential policy options.
} 
Table 2 - 2: Timeline of the Regulatory Actions in the $\mathrm{EU}^{23}$

\begin{tabular}{|c|c|}
\hline DATE & CONTENT \\
\hline $05 / 04 / 2011$ & $\begin{array}{l}\text { - Green Paper "The EU corporate governance framework" released by the European } \\
\text { Commission (public consultation period until July 22, 2011). }\end{array}$ \\
\hline $22 / 03 / 2012$ & $\begin{array}{l}\text { - Discussion Paper "An Overview of the Proxy Advisory Industry. Considerations on } \\
\text { Possible Policy Actions" released by the European Securities and Market Authority } \\
\text { (public consultation period until June 25, 2012). }{ }^{24}\end{array}$ \\
\hline $19 / 02 / 2013$ & $\begin{array}{l}\text { - Final Report "Feedback statement on the consultation regarding the role of the proxy } \\
\text { advisory industry" released by the European Securities and Market Authority (based on } \\
64 \text { responses) with the conclusion that ESMA encourages the proxy advisory industry to } \\
\text { develop its own code-of-conduct principles. }\end{array}$ \\
\hline $28 / 10 / 2013$ & $\begin{array}{l}\text { - First Draft "Public Consultation on Best Practice Principles for Governance Research } \\
\text { Provides" released by BPP Group Consultation (public consultation period until } \\
\text { December 20,2013). }\end{array}$ \\
\hline March 2014 & $\begin{array}{l}\text { - Based on the results of the "Public Consultation on Best Practice Principles for } \\
\text { Governance Research Provides" and the } 44 \text { received responses }{ }^{26} \text {, BPP Group } \\
\text { Consultation plans to ratify and publish a final set of code-of-conduct principles for } \\
\text { governance research providers. }\end{array}$ \\
\hline Sep / Oct 2014 & - BPP Group Consultation plans to meet for a first review on the ratified principles. \\
\hline
\end{tabular}

In a Green Paper in 2011, the European Commission has addressed issues such as the influence, the method consistency, and conflicts of interests of proxy advisors. In a separate initiative but based on responses to the Green Paper and further 'fact-finding' activities in 2011, ESMA (2012) released a discussion paper on potential market failures related to the proxy advisory business for consultation. The purpose of this discussion paper was to outline the developments of the European proxy advisory industry, to raise 12 key issues for consultation with respect to potential market failures within the proxy advisory business, and to discuss potential policy options. As the consultation process did not provide clear examples of severe market failures related to the proxy advisory business, ESMA decided not to consider any binding regulatory measures. Instead, ESMA mandated the proxy advisory business to develop a European wide code of conduct standard to increase integrity and transparency (ESMA, 2013, pp. 5-6). Table 2 - 2 summarizes the regulatory initiatives at European level.

\footnotetext{
${ }^{23}$ See EC (2011), ESMA (2012/2013), and BPP Group Consultation (2013).

${ }^{24}$ ESMA (2012, pp. 39-40) invited comments on the following issues: (1) the influence of proxy advisors in shifting voting outcomes (question $1 \& 2$ ), (2) the use of proxy advisors by investors to shift stewardship responsibilities (question 3), (3) conflicts of interests within proxy advisors (question $4 \& 5$ ), (4) the incorporation of local market trends into proxy recommendations ('one-size-fits-all' approach) (question 6), (4) transparency and accuracy of the methods underlying the voting process (question 7), and (5) potential policy options for future regulation (question 8 to 12 ).

${ }^{25} \mathrm{http}$ ://www.esma.europa.eu/consultation/Consultation-DP-Overview-Proxy-Advisory-IndustryConsiderations-Possible-Policy-Options, last accessed June 30, 2014.

${ }^{26} \mathrm{http}: / /$ bppgrp.info/?page_id=111, last accessed June 30, 2014.
} 
During the different consultation processes (i.e., EC, 2011; ESMA, 2012), two issues have been frequently raised; the influence of proxy advisors at European AGMs and the reliability of voting recommendations. ESMA (2012, p. 39), for example, has invited comments on the questions (1) whether proxy advisors have a significant impact on the voting results at European AGMs and (2) whether improvements should be made with respect to transparency and methodology to provide more reliable and independent voting recommendations. Overall, the feedback during the consultation period has highlighted that despite anecdotal evidence - empirical evidence on the role and influence of proxy advisors at European AGMs is not available (ESMA, 2013).

\subsubsection{Related Literature}

This paper contributes to two related streams of literature. The first is research on the determinants of shareholder meetings' voting outcomes (e.g., Cai et al., 2009; Choi et al., 2010; Ertimur et al., 2013). While this literature suggests that ISS - as the most influential proxy advisor - potentially affects voting outcomes at U.S. shareholder meetings by a shift of up to $26 \%$ of shareholder votes, it has been silent on whether proxy advisors affect voting outcomes at shareholder meetings outside the U.S. ${ }^{27}$ The second strand of literature addresses the (governance-related) determinants of proxy voting recommendations (e.g., Choi et al., 2009; Daines et al., 2010). So far, this literature provides rather mixed evidence on the link between proxy recommendations and governance ratings / governance provisions. While Choi et al. (2009) find significant correlations between ISS recommendations and governancerelated factors, Daines et al. (2010) show that ISS recommendations are only weakly correlated with ISS corporate governance ratings. However, none of the previous studies examines this link for a non-U.S. setting. Table 2 - 3 summarizes prior related literature.

\footnotetext{
${ }^{27}$ In a recent survey paper on proxy advisors in France and Japan, Dubois (2012, p. 94) frames this as follows: "There has not yet been any empirical research regarding the influence of proxy advisors' recommendations on voting results in countries outside the United States. Given the importance of foreign investors in France and Japan and the number of ISS's client, it is safe to assume that their influence is important and gradually increasing, especially on foreign markets where investors are likely to rely on the opinion of a more knowledgeable third-party."
} 
Table 2 - 3: Prior Related Literature on Proxy Voting Advisory

\begin{tabular}{|c|c|c|}
\hline Authors & Sample & Main Findings \\
\hline \multicolumn{3}{|c|}{ Panel A. Proxy Voting Recommendations and Voting Outcomes } \\
\hline $\begin{array}{l}\text { Bethel and } \\
\text { Gillan (2002) }\end{array}$ & $\begin{array}{l}\text { U.S. sample of } \\
1,321 \text { management } \\
\text { proposals for } 1998\end{array}$ & $\begin{array}{l}\text { Despite other significant determinants (e.g., broker vote, size, and } \\
\text { ownership structure) negative ISS recommendations are associated } \\
\text { with a drop of } 13 \% \text { in shareholder support. }\end{array}$ \\
\hline $\begin{array}{l}\text { Cai et al. } \\
(2009)\end{array}$ & $\begin{array}{l}\text { U.S. sample of } \\
13,384 \text { director } \\
\text { elections between } \\
2003 \text { and } 2005\end{array}$ & $\begin{array}{l}\text { Negative ISS recommendations matter most and explain a statistically } \\
\text { and economically significant part of shareholder votes. Specifically, a } \\
\text { "vote against" recommendation by ISS on average results in } 19 \% \\
\text { fewer supportive shareholder votes. }\end{array}$ \\
\hline $\begin{array}{l}\text { Choi et al. } \\
(2010)\end{array}$ & $\begin{array}{l}\text { U.S. sample of over } \\
12,000 \text { director } \\
\text { elections between } \\
2005 \text { and } 2006\end{array}$ & $\begin{array}{l}\text { ISS issued withhold recommendations for } 6.8 \% \text { of all covered } \\
\text { director elections, whereas Glass Lewis recommended the same for } \\
18.8 \% \text {. ISS recommendations shift on average } 13 \% \text { of the } \\
\text { corresponding shareholder votes, whereas Glass Lewis (as the second } \\
\text { most influential advisor) affects on average 'only' } 3.6 \% \text { of the } \\
\text { shareholder votes. }\end{array}$ \\
\hline $\begin{array}{l}\text { Ertimur et al. } \\
(2009)\end{array}$ & $\begin{array}{l}\text { U.S. sample of } \\
1,332 \text { shareholder } \\
\text { initiateves from } \\
1997 \text { to } 2007\end{array}$ & $\begin{array}{l}\text { ISS recommendations to vote for the shareholder initiative (i.e., } \\
\text { shareholder proposals or vote-no campaigns) are associated with an } \\
\text { increase of up to } 25 \% \text { of votes casted for the shareholder initiative. }\end{array}$ \\
\hline $\begin{array}{l}\text { Ertimur et al. } \\
\text { (2011) }\end{array}$ & $\begin{array}{l}\text { U.S. sample of over } \\
180 \text { firms with } \\
\text { option backdating } \\
(2006-2007)\end{array}$ & $\begin{array}{l}\text { Negative ISS recommendations related to the option backdating } \\
\text { investigation significantly affect the shareholder voting. Supportive } \\
\text { shareholder votes of directors drop by } 27 \% \text { if those directors receive a } \\
\text { "vote against" recommendation by ISS which is related to the option } \\
\text { backdating investigation. }\end{array}$ \\
\hline $\begin{array}{l}\text { Ertimur et al. } \\
(2013)\end{array}$ & $\begin{array}{l}1,275 \text { U.S. firms in } \\
\text { the S\&P } 1500 \text { with } \\
\text { 'say on pay' votes } \\
\text { during } 2011\end{array}$ & $\begin{array}{l}\text { Although both ISS and Glass Lewis consider poor firm performance, } \\
\text { high levels of CEO pay, and weak 'pay for performance' when } \\
\text { releasing "vote against" recommendations, the overlap between both } \\
\text { recommendations is limited. The release of negative ISS } \\
\text { recommendations induces small but significantly negative market } \\
\text { reactions (negative mean abnormal returns between }-0.5 \% \text { and }-0.7 \% \text { ) } \\
\text { in cases where those recommendations were less expected. Negative } \\
\text { recommendations issued by ISS (Glass Lewis) correlate with a drop } \\
\text { of } 24.7 \%(12.9 \%) \text { in votes casted in favor of the compensation plans. } \\
\text { This is even more pronounced - with a drop of } 38.3 \% \text { - when both } \\
\text { advisors recommend to vote against the compensation plan at the } \\
\text { same time. Firms receiving low shareholder support and especially } \\
\text { negative ISS recommendations on their compensation plans are more } \\
\text { likely to change their compensation plans, but markets do not react on } \\
\text { the announcement of those changes. }\end{array}$ \\
\hline
\end{tabular}

Panel B. Proxy Voting Recommendations and Corporate Governance Ratings

\begin{tabular}{lll}
\hline $\begin{array}{l}\text { Choi et al. } \\
(2009)\end{array}$ & $\begin{array}{l}\text { U.S. sample of over } \\
12,000 \text { director } \\
\text { elections between } \\
2005 \text { and } 2006\end{array}$ & $\begin{array}{l}\text { ISS considers especially governance-related factors (i.e., board and } \\
\text { compensation issues), whereas Proxy Governance and Glass Lewis } \\
\text { focus rather on compensation-related factors and audit / disclosure- } \\
\text { related factors, respectively. }\end{array}$ \\
$\begin{array}{l}\text { Daines et al. } \\
(2010)\end{array}$ & $\begin{array}{l}\text { U.S. sample of } \\
\text { 34,761 ISS recom- } \\
\text { mendations for }\end{array}$ & $\begin{array}{l}\text { Weak evidence exists for a link between ISS recommendations and } \\
\text { ISS governance ratings. A one-standard-deviation increase in ISS } \\
\text { governance ratings (i.e., an increase of 28.5 points) only correlates } \\
\text { with a 6.3 percentage points higher probability in receiving } \\
\text { supportive ISS recommendations. Despite positive correlations } \\
\text { between ISS recommendations and voting outcomes (association of } \\
\text { around 16\%), CGQ ratings are negatively correlated with voting } \\
\text { outcomes. }\end{array}$ \\
& &
\end{tabular}




\section{Proxy Voting Recommendations and Voting Outcomes}

One of the first studies addressing determinants of AGM voting outcomes was conducted by Bethel and Gillan (2002). For a sample of 1,321 voting items (based on S\&P SuperComposite firms) for the proxy season 1998, they examine the influence of ISS recommendations on voting outcomes. Their results suggest that despite other significant determinants (e.g., broker vote, size, and ownership structure) ISS's recommendations to vote against management proposals are associated with a drop of $13 \%$ in votes casted for the management proposal. Two recent studies, Cai et al. (2009) and Choi et al. (2010), provide evidence on the influence of proxy advisors for large U.S. samples of director election voting items. In particular, for a U.S. sample of 13,384 director elections (and 2,483 shareholder meetings) between 2003 and 2005, Cai et al. (2009) show that a "vote against" recommendation by ISS correlates with on average 19\% fewer supportive shareholder votes. Based on a U.S. sample of over 12,000 director elections between 2005 and 2006, Choi et al. (2010) present evidence that ISS's recommendations shift on average $13 \%$ of the corresponding shareholder votes, whereas Glass Lewis (as the second most influential advisor) affects on average $3.6 \%$ of the shareholder votes. ${ }^{28}$ In addition, Choi et al. (2010) point out that the coverage rates of four different proxy advisors (ISS, Glass Lewis, Egan Jones, and Proxy Governance) as well as the frequency to issue withhold recommendations differ in a substantial way. ISS, for example, issued withhold recommendations for $6.8 \%$ of all covered director elections, whereas Glass Lewis recommended the same for $18.8 \%$ of all covered elections.

In the most recent study, Ertimur et al. (2013) examine the economic role of two proxy advisors (ISS and Glass, Lewis \& Co.) in the context of non-binding U.S. 'say on pay' votes. Based on recommendations of both proxy advisors for 1,275 U.S. firms in the S\&P 1500 during 2011, Ertimur et al. (2013) analyze the market reaction to the release of voting recommendations, the influence of these recommendations on shareholder votes, the firms' response to the vote, and subsequent effects on firm value. In particular, their results reveal small but significantly negative market reactions (negative mean abnormal returns between $-0.5 \%$ and $-0.7 \%$ ) only for negative ISS recommendations. With respect to voting outcomes, their results suggest that negative recommendations issued by ISS (Glass Lewis) correlate with a drop of $24.7 \%(12.9 \%)$ in votes casted in favor of the compensation plans. This is even more pronounced - with a drop of $38.3 \%$ - when both advisors recommend to vote against

\footnotetext{
${ }^{28}$ Choi et al. (2010) emphasize that their results on the proxy advisors' influence are sensitive to the applied econometric modeling (correlations varies between $6 \%$ and $13 \%$ depending on the model).
} 
the compensation plan at the same time. Finally, their results indicate that firms receiving low shareholder support and especially negative ISS recommendations on their compensation plans are more likely to change their compensation plans, but that markets do not react to the announcement of these changes. ${ }^{29}$

\section{Proxy Voting Recommendations and Corporate Governance Ratings}

Based on a U.S. sample with over 12,000 director elections between 2005 and 2006, Choi et al. (2009) provide first empirical evidence on governance-related determinants of four different proxy advisors (ISS, Glass Lewis, Egan Jones, and Proxy Governance). Specifically, they find that all four proxy advisors base their recommendations, among other things, on firm-level governance factors. However, the individual voting recommendations as well as the underlying governance criteria differ. ISS, for example, considers especially governancerelated factors (i.e., board and compensation issues), whereas Proxy Governance and Glass Lewis rather focus on compensation-related factors and audit / disclosure-related factors, respectively (Choi et al., 2009, pp. 649, 675).

In contrast to Choi et al. (2009), Daines et al. (2010) examine directly the relation between ISS voting recommendations, ISS governance ratings (Corporate Governance Quotient, CGQ), and voting results. Based on 34,761 voting recommendations released by ISS for the U.S. proxy seasons 2005, 2006, and 2007, they find only weak evidence for a link between ISS recommendations and ISS governance ratings. ${ }^{30}$ In addition, their results further suggest that despite positive correlations between ISS recommendations and voting outcomes (association of around 16\%), CGQ ratings are negatively correlated with voting outcomes. Overall, their findings provide only low correlations between ISS recommendations and ISS governance ratings suggesting a rather low degree of method consistency between both products with respect to the employed governance perception.

\footnotetext{
${ }^{29}$ Other studies, examining issues related to voting outcomes, present direct or indirect evidence on the influence of proxy advisors. For a U.S. sample of 1,332 shareholder initiatives (1,198 shareholder proposals and 134 voteno campaigns) related to compensation issues for the period between 1997 and 2007, Ertimur et al. (2009, p. 23) provide evidence that ISS recommendations to vote for the shareholder initiative are associated with an increase of up to $25 \%$ of votes casted for the shareholder initiative. Based on a U.S. sample of over 180 firms that announced an option backdating investigation between 2006 and 2007, and the corresponding ISS recommendations on director elections, Ertimur et al. (2011) show that negative ISS recommendations related to the option backdating investigation significantly affect shareholder voting. Specifically, shareholder support drops by $27 \%$ if directors receive a negative ISS recommendation which relates to the option backdating investigation.

${ }^{30}$ Their results suggest that a one-standard-deviation increase in ISS governance ratings correlates with a 6.3 percentage points higher probability in receiving supportive ISS recommendations.
} 


\subsection{Empirical Predictions}

\section{Proxy Voting Recommendations and Voting Outcomes}

Prior U.S. findings suggest that ISS voting recommendations affect voting outcomes at AGMs (e.g., up to $26 \%$ as documented by Ertimur et al., 2013). However, taking the distinct different institutional setup into account, it becomes less clear whether and to what extent ISS voting recommendations affect voting outcomes in Germany. In contrast to the U.S., the German market is characterized by a stakeholder model of corporate governance in which, among other things, codetermination, large shareholders, and banks play important roles (e.g., Goergen et al., 2008). Specifically, compared to the U.S., the German capital market exhibits a rather low degree of dispersed ownership and institutional (U.S.) holdings (e.g., Cziraki et al., 2010, p. 748), and lacks experience with proxy voting advisory.

ESMA (2012), for example, summarizes the differences between the European and the U.S. proxy advisory industry as follows. Although at different levels, proxy voting advisory in Europe is a relatively recent phenomenon and still developing. In contrast to the established U.S. market, the proxy advisory market in Europe is small in terms of coverage and turnover. Nevertheless, ESMA (2012, p. 16) expects that "proxy advisory is growing in prominence and investors are increasingly using proxy advisor services for the purposes of voting and carrying out their stewardship responsibilities in general”.

Although ESMA acknowledged the extent of prior U.S. evidence on the influence of proxy advisors, it invited - as outlined in section 2.2 - comments on the question whether and to what extent proxy advisors affect voting outcomes at a European level (ESMA, 2012, p. 17-19). Based on the results of the ESMA consultation process in 2012, anecdotal evidence suggests that proxy advisors are considered as influential and able to causally affect voting outcomes at European AGMs (ESMA, 2013, p. 13). However, some respondents (notably investors) argued that especially domestic shareholder concentration and the degree of the institutional shareholder's investment potential affect the influence of proxy advisors (ESMA, 2013, p. 12). As outlined in section 2.2, prior U.S. evidence supports this. On a more general level, Bethel and Gillan (2002), for example, predict and find evidence that firm and AGM characteristics, like size, performance, and ownership structure, affect voting results. More directly, Ertimur et al. (2013) provide evidence that especially ownership concentration and the rationale behind the recommendations moderate the relationship between proxy recommendations and voting outcomes. 
Thus, I expect to find a significant correlation between ISS recommendations and voting outcomes, yet on a potentially lower level as compared to the correlations documented for the U.S. market. Moreover, I expect significant variations in the cross-section. In particular, I expect that the correlation between ISS recommendations and voting outcomes is, among other things, moderated by ownership, client level (i.e., number of clients receiving / following ISS recommendations), and voting turnout (i.e. voting presence at the AGM). Specifically, I assume that high free float, high client level, and low voting presence increase the association between ISS recommendations and voting outcomes.

\section{Proxy Voting Recommendations and Governance Ratings}

To address the consistency of ISS voting recommendations, I follow Daines et al. (2010) and compare the ISS voting recommendations with another product marketed by ISS, namely ISS corporate governance ratings. Following Daines et al. (2010, p. 455), there are several reasons to expect a relation between ISS's recommendations and its governance ratings. In particular, ISS's selling strategy (both products are often sold as bundled products) implies that ISS governance ratings are relevant to voting decisions. In addition, inputs for both ISS products are to some extent similar (e.g., criteria for board structure and independence). ISS (2010, p. 7), for example, states that it ensures "alignment of its Ratings Criteria in CGQ with ISS's Voting Policy [...] to encourage companies to adopt best practices in Corporate Governance." Thus, if both products consistently provide useful information to shareholders with respect to governance issues, it is plausible to assume a certain degree of correlation between both.

Consequently, I expect that high (low) correlations between the two commercially available products indicate a rather high (low) consistency with respect to the governance standards employed by ISS. High method consistency might reflect accountability and transparency of the advisory services, which in turn serve the interests of clients / investors. In the course of the ESMA (2012, p. 17) consultation process, institutional investors have been highlighting that "the accuracy, independence and reliability of a proxy advisor's research and advice are the most important priorities when selecting proxy advisor services." As outlined in section 2.2, U.S. evidence on the link between proxy recommendations and governance ratings / provisions is rather mixed. While Choi et al. (2009) find significant correlations between ISS's recommendations and governance-related factors, Daines et al. (2010) show that ISS's recommendations are only weakly correlated with ISS's corporate governance 
ratings. For my European setting, I thus leave it as an empirical question whether and to what extent both products marketed by ISS are consistent in terms of the employed governance perceptions.

\subsection{Regression Models}

\section{Proxy Voting Recommendations and Voting Outcomes}

To address the question of whether and to what extent proxy recommendations correlate with voting outcomes, I use the following basic regression model:

$$
\begin{gathered}
\text { VOTING_RESULT }_{\mathrm{iv}}=\alpha+\gamma_{1} \text { ISS_AGAINST }_{\mathrm{iv}}+\gamma_{2} \text { MODERATOR }_{\mathrm{iv}} \\
+\gamma_{3} \text { ISS_AGAINST } \times \text { MODERATOR }_{\mathrm{iv}}+\varepsilon
\end{gathered}
$$

The dependent variable VOTING_RESULT ${ }_{\text {iv }}$ stands for the voting result (in \%) casted in favor of a specific voting item (management proposal) of firm i and AGM voting item v. ${ }^{31}$ ISS_AGAINST is a dummy variable indicating with 1 that ISS recommends to vote against a specific AGM voting item, and zero otherwise. ${ }^{32}$ MODERATOR stands for different variables which are expected to moderate the relationship between ISS "vote against" recommendations and voting results. Specifically, I consider the following dummy variables as moderators: FREE FLOAT (with 1 if the firm's free float is above average, and 0 otherwise), and invTURNOUT (with 1 if the firm's voting presence is below average, and 0 otherwise). To consider the potential moderating effect of the number of clients receiving ISS recommendations (ISS's CLIENT BASE), I use a dummy variable indicating whether ISS issues Long-Form (LF) reports or Short-Form (SF) reports (with 1 if the firm is covered by ISS LF-report, and 0 otherwise). Compared to SF- reports, LF-reports commonly contain a more comprehensive analysis of the individual AGM voting items and additional information

\footnotetext{
${ }^{31}$ To ease the interpretation of the regression results, I follow Ertimur et al. $(2009$, p. 20) and use voting results in percent as the dependent variable. However, as this dependent variable is a percentage with a fixed range between 0 and 100, I challenge my main findings. I re-estimate the regressions with a logit-transformed dependent variable. In line with Bethel and Gillan (2002, p. 48), I employ the following transformation: $\log [\%$ voting result / (100 - \%voting results)]. Untabulated results based on the logit transformed dependent variable are in line with my original findings.

${ }^{32}$ Alternatively, I follow Ertimur et al. (2009, p. 23) and use residuals of ISS's recommendations (obtained from regressing the variable 'ISS_AGAINST' on firm characteristics which are likely to explain the voting decision by ISS, like firm performance, size, ownership structure, analyst following, and blue chip index membership) to measure the influence of ISS recommendations on voting results. Untabulated results confirm my main findings. However, the drawback of using this approach is twofold: economic significance of regression results is hard to assess and firm-fixed effects are not applicable anymore in the main regression (unless one might find and include (firm) characteristics which vary at AGM voting item level). Especially due to the latter point, I do not use the residuals approach in the first place.
} 
about the governance and ownership structure of the respective firm. For example, the average page numbers of LF-reports and SF-reports are 13.5 and 5.3, respectively. The two different levels of proxy reports basically reflect the aggregated institutional investors' demand for the comprehensiveness of ISS reports. Thus, I expect that the differentiation between ISS LF- and SF-reports reflects to some extent the client base of ISS (i.e., LF-reports are followed by a larger client base than short form reports).

The interaction term, ISS_AGAINST $\times$ MODERATOR, measures the moderating effect of the different moderators on ISS "vote against" recommendations. For example, when using invTURNOUT as the moderating variable, ISS_AGAINST $\times$ invTURNOUT measures the cross-sectional variation in the ISS "vote against" recommendations and voting results relationship with respect to the voting presence. Consistent with section 2.3 , I expect in line with my first prediction that the coefficient estimates $\gamma_{1}$ and $\gamma_{2}$ become significant at conventional levels and obtain negative signs. To address heteroskedasticity and crosssectional dependence in the dataset, I use standard errors which are heteroskedasticity robust (White, 1980) and one-way clustered at AGM voting item level (Gow et al., 2010; Petersen, 2009). To control for (observed / unobserved) firm characteristics which are likely to affect both the voting recommendations and the shareholder's voting behavior, I employ firm-fixed effects in the regression model. ${ }^{33}$

\section{Proxy Voting Recommendations and Governance Ratings}

To address the second prediction, I use the following basic probit regression model based on a sample of all firms covered by ISS LF-reports and the corresponding 918 voting items (GRId data is not available for firms covered by ISS SF-reports):

$$
\begin{aligned}
\text { ISS_AGAINST }_{\text {iv }}= & \alpha+\gamma_{1} \operatorname{GRId}_{\text {iv }}\left(\sum \gamma_{1} \text { GRId_SUBSCORES }_{\text {iv }}\right)+\sum \gamma_{2} \text { FIRM_CONTROL }_{\text {iv }} \\
& +\sum \gamma_{3} \text { INDUSTRY }_{\text {iv }}+\varepsilon
\end{aligned}
$$

ISS_AGAINST is defined as for model (1). GRId (Governance Risk Indicator) stands for the commercial corporate governance rating marketed by ISS. Based on up to 80 single governance variables, ISS provides - since 2010 - GRId ratings for over 8,000 firms

\footnotetext{
${ }^{33}$ OLS regressions with firm-level clustered standard errors and different control variables (i.e., size, ownership concentration, blue chip index membership, analyst following, and industry dummies) produce similar results.
} 
worldwide (including 220 German firms). ${ }^{34}$ Besides the overall GRId rating, GRId sub-scores are further available for the following four dimensions: board structure, compensation issues, shareholder rights, and audit issues (RiskMetrics Group, 2010). Thus, GRId_SUBSCORES reflects the different sub-scores of the commercial corporate governance rating (i.e., subscores for board, compensation, shareholder rights, and audits). FIRM_CONTROL is a vector of different firm-level control variables. Specifically, I consider size as log of total assets, free float, and blue chip (HDAX) index membership to control for firm-level effects. To additionally control for industry differences, the regression model contains industry-fixed effects. To address heteroskedasticity and time-series dependence in the dataset, I use standard errors which are heteroskedasticity robust and one-way clustered at firm level.

\subsection{Results}

\subsubsection{Sample Selection}

Table 2 - 4 presents the sample selection process. To obtain the final sample, I merge - in a first step - the German Worldscope firm universe with corresponding firm-level data on ISS proxy voting reports provided by Thomson Reuters Advanced Analytics (TRAA). Since the coverage of ISS proxy voting reports in TRAA is limited, i.e., most recent proxy voting reports are only available for the proxy season 2010, and firm disclosure on the voting results of past AGMs is incomplete, I base my analyses on the proxy season 2010. Overall, ISS covers 377 German firms during the proxy season 2010. However, TRAA only provides ISS voting reports for firms with shareholder meetings in the period between May 2010 and December 2010. This in turn results in a sample of 279 ISS reports $(2,478$ voting items on management proposals) which are available in TRAA for the proxy season 2010 (with AGMs between May 2010 and December 2010). These reports are divided in 104 Long-Form (LF) and 175 Short-Form (SF) ISS reports. As reflected in Table 2 - 5, investors seek comprehensive reports (i.e., LF-reports) especially for large and visible firms in the market.

Worldscope provides relevant financial and accounting data for all 279 firms and ISS reports. However, final voting results are only available for 185 ISS reports (either on the company's website or by request). Consequently, the final sample consists of 185 ISS reports (1,664 voting items) with 92 firms (918 voting items) covered by ISS LF-reports and 93 firms

\footnotetext{
${ }^{34}$ ISS provided the Corporate Governance Quotient (CGQ) as the predecessor of the GRId rating until 2010. Following Larcker and Tayan (2011), both ratings are not materially different.
} 
(746 voting items) by ISS SF-reports. Potential sample selection problems due to restrictions in the TRAA coverage and in the availability of voting results are discussed in detail in section 2.5.4.

Table 2 - 4: Sample Selection

\begin{tabular}{|c|c|c|c|}
\hline Selection Criteria & & $\begin{array}{c}\text { Firm } \\
\text { Observations }\end{array}$ & $\begin{array}{l}\text { Voting } \\
\text { Items } \\
\end{array}$ \\
\hline Start (Worldscope GER Universe 2010, with ISIN available) & & 817 & \\
\hline ISS coverage ( 377 firms are covered by ISS) & -440 & 377 & \\
\hline ISS reports not available in TRAA database & -98 & 279 & 2,478 \\
\hline - Firms with Long-Form (LF) ISS Report Coverage: & & 104 & 1,061 \\
\hline - Firms with Short-Form (SF) ISS Report Coverage: & & 175 & 1,417 \\
\hline Voting results not available ${ }^{35}$ & -94 & 185 & 1,664 \\
\hline Final sample (German Proxy Season 2010) & & 185 & 1,664 \\
\hline - Firms with Long-Form (LF) ISS Report Coverage: & & 92 & 918 \\
\hline - Firms with Short-Form (SF) ISS Report Coverage: & & 93 & 746 \\
\hline
\end{tabular}

\subsubsection{Descriptive Analyses}

Table 2 - 5 presents descriptive statistics on AGM characteristics, ISS voting characteristics, and firm-level characteristics separately for firms covered by ISS LF-reports and SF-reports. To that end, the descriptive analysis provides insights into the two ISS's coverage levels which not only differ with respect to the client base but also with respect to the comprehensiveness of ISS reports (e.g., LF-reports contain a more comprehensive analysis of the individual AGM voting items and additional information about the governance and ownership structure of the respective firm). Panel A of Table 2 - 5 shows that - given the overall sample size of 918 (746) voting items in the LF-sample (SF-sample) - the covered AGM agendas contain on average 9.97 voting items (8.02 voting items) with a substantial variation between 4 and 33 ( 3 and 28) voting items. In addition, the corresponding ISS LFreports (SF-reports) have on average 13.54 (5.29) pages and contain 1.15 (0.79) ISS "vote against" recommendations (i.e., ISS recommendations to vote against a specific voting item / management proposal). The latter finding corresponds to an ISS's rejection rate of $11.54 \%$ (9.79\%). ${ }^{36}$ In comparison, Choi et al. (2010) and Ertimur et al. (2013) document for U.S. director elections and U.S. 'say on pay' votes a corresponding rate of $6.8 \%$ and $11.3 \%$, respectively. However, ISS's rejection rate appears to be higher in the German sample.

\footnotetext{
${ }^{35}$ In 108 cases, I wrote an E-Mail to the respective firm / head of investor relations and requested the voting results. In 49 cases, the firms responded and provided the relevant data. Although the general disclosure quality improved following the transposition of the European Directive 2007/36/EC on shareholder rights in Germany (Gesetz zur Umsetzung der Aktionärsrichtlinie, 2009), especially smaller firms only provide - in line with the requirements of the law - the most recent voting result for download at their websites.

${ }^{36}$ Based on Panel A and B of Table 2 - 5: 11.54 = 106 / 918; $9.79=73 / 746$.
} 
Specifically, when considering only director elections ('say on pay' votes) in the German sample, ISS's rejection rate goes up to $12.5 \%(43.1 \%) .{ }^{37}$ With respect to differences in the ISS coverage, Panel $\mathrm{C}$ of Table 2 - 5 shows that firms covered by LF-reports are on average larger, more profitable, more likely members of a German blue chip index, and have larger analyst following. However, both firm groups do not appear to differ with respect to free float.

Table 2 - 5: Descriptive Analyses

\begin{tabular}{|c|c|c|c|c|c|c|c|c|}
\hline & \multicolumn{4}{|c|}{$\begin{array}{l}\text { Long-Form (LF) Coverage } \\
\text { (based on } 92 \text { firms \& } 918 \text { voting items) }\end{array}$} & \multicolumn{4}{|c|}{$\begin{array}{c}\text { Short-Form (SF) Coverage } \\
\text { (based on } 93 \text { firms \& } 746 \text { voting items) }\end{array}$} \\
\hline & Sum & Mean & Min. & Max. & Sum & Mean & Min. & Max. \\
\hline \multicolumn{9}{|c|}{ Panel A. AGM - Characteristics } \\
\hline Agenda items (non-voting/voting) & 1046 & 11.37 & 5 & 34 & 865 & 9.30 & 4 & 29 \\
\hline Mgt. Rec. (all voting items) & 918 & 9.97 & 4 & 33 & 746 & 8.02 & 3 & 28 \\
\hline \multicolumn{9}{|c|}{ Panel B. ISS - Voting Characteristics } \\
\hline ISS Reports (Number of pages) & 1246 & 13.54 & 7 & 30 & 492 & 5.29 & 3 & 12 \\
\hline ISS “vote against” (Mgt. Rec.-level) & 106 & 1.15 & 0 & 6 & 73 & 0.79 & 0 & 4 \\
\hline
\end{tabular}

Panel C. Firm Characteristics

\begin{tabular}{lcccccccc}
\hline Size (log of TA) & - & 14.00 & 10.89 & 21.36 & - & 11.63 & 7.25 & 17.19 \\
BTM & - & 0.90 & .04 & 5.31 & - & 1.21 & -.65 & 41.14 \\
ROA & - & 0.07 & -.45 & .45 & - & -.04 & -4.12 & .95 \\
DAX & 6 & 0.06 & 0 & 1 & 0 & 0 & 0 & 0 \\
MDAX & 20 & 0.21 & 0 & 1 & 1 & .01 & 0 & 1 \\
TecDAX & 15 & 0.16 & 0 & 1 & 1 & .01 & 0 & 1 \\
SDAX & 22 & 0.23 & 0 & 1 & 2 & .02 & 0 & 1 \\
Prime Standard (FWB) & 87 & 0.90 & 0 & 1 & 50 & .54 & 0 & 1 \\
General Standard (FWB) & 5 & 0.05 & 0 & 1 & 21 & .23 & 0 & 1 \\
Entry Standard (FWB) & 0 & 0 & 0 & 0 & 9 & .10 & 0 & 1 \\
Open Market (FWB) & 0 & 0 & 0 & 0 & 3 & .03 & 0 & 1 \\
Listed at Regional Stock Exchanges & 0 & 0 & 0 & 0 & 10 & .11 & 0 & 1 \\
Analyst Coverage (AC) & 89 & 0.96 & 0 & 1 & 64 & .74 & 0 & 1 \\
Analyst Following (AF) & - & 10.45 & 0 & 35 & - & 1.91 & 0 & 18 \\
GRId (ISS CG Score) & - & 9.04 & 5 & 12 & - & - & - & - \\
Financial industry (SIC 60-69) & 17 & 0.18 & 0 & 1 & 19 & .22 & 0 & 1 \\
Free Float & - & 60.44 & 7 & 100 & - & 61.12 & 0 & 100 \\
Ownership of 3 largest shareholders & - & 45.76 & 3.68 & 93.46 & - & - & - & - \\
Ownership of 3 largest inst. investors & - & 12.79 & 0 & 91.6 & - & - & - & - \\
\hline Notes: This table displays descrivtive
\end{tabular}

Notes: This table displays descriptive statistics of all variables used in this study. The overall sample consists of 1,664 AGM voting items based on 185 individual firms (from the German proxy season 2010). For further information on the individual Mgt. Rec. items (routine vs. non-routine voting items), see Table 2 - 7.

Complementing the descriptive statistics, Table $2-6$ provides Spearman correlation coefficients between the main variables used in this study. In line with the paper's first prediction, the correlation coefficient between the variables 'Voting Results' and 'ISS Against' is significantly negative suggesting that negative ISS recommendations correlate

\footnotetext{
${ }^{37}$ For further details, see Table $2-7$.
} 
with less shareholder support. In addition, Table 2 - 6 further suggests that - pertaining to the paper's second prediction - ISS "vote against" recommendations significantly and negatively correlate with ISS commercially available governance ratings (GRId). This implies that firms with high GRId ratings, which reflect higher governance quality, receive on average less negative ISS recommendations.

Table 2 - 6: Correlation Analysis

\begin{tabular}{|c|c|c|c|c|c|c|c|c|c|c|c|}
\hline \multirow{2}{*}{$\begin{array}{c}\text { Sample } \\
(\mathrm{N}=1,664)\end{array}$} & \multicolumn{11}{|c|}{ Non-parametric Spearman Correlations } \\
\hline & & 1 & 2 & 3 & 4 & 5 & 6 & 7 & 8 & 9 & 10 \\
\hline VOTING RESULT & 1 & 1 & & & & & & & & & \\
\hline ISS AGAINST & 2 & $\begin{array}{l}-0.33 \\
(0.00)\end{array}$ & 1 & & & & & & & & \\
\hline invTURNOUT & 3 & $\begin{array}{l}-0.21 \\
(0.00)\end{array}$ & $\begin{array}{l}-0.02 \\
(0.29)\end{array}$ & 1 & & & & & & & \\
\hline FREE FLOAT & 4 & $\begin{array}{l}-0.16 \\
(0.00)\end{array}$ & $\begin{array}{l}-0.03 \\
(0.19)\end{array}$ & $\begin{array}{c}0.43 \\
(0.00)\end{array}$ & 1 & & & & & & \\
\hline CLIENT BASE & 5 & $\begin{array}{l}-0.21 \\
(0.00)\end{array}$ & $\begin{array}{c}0.02 \\
(0.24)\end{array}$ & $\begin{array}{c}-0.12 \\
(0.00)\end{array}$ & $\begin{array}{c}-0.02 \\
(0.40)\end{array}$ & 1 & & & & & \\
\hline SIZE & 6 & $\begin{array}{l}-0.11 \\
(0.00)\end{array}$ & $\begin{array}{l}-0.01 \\
(0.74)\end{array}$ & $\begin{array}{l}-0.21 \\
(0.00)\end{array}$ & $\begin{array}{l}-0.05 \\
(0.02)\end{array}$ & $\begin{array}{c}0.66 \\
(0.00)\end{array}$ & 1 & & & & \\
\hline HDAX & 7 & $\begin{array}{l}-0.20 \\
(0.00)\end{array}$ & $\begin{array}{l}-0.01 \\
(0.75)\end{array}$ & $\begin{array}{l}-0.02 \\
(0.33)\end{array}$ & $\begin{array}{c}0.16 \\
(0.00)\end{array}$ & $\begin{array}{c}0.52 \\
(0.00)\end{array}$ & $\begin{array}{c}0.55 \\
(0.00)\end{array}$ & 1 & & & \\
\hline $\mathbf{A C}$ & 8 & $\begin{array}{l}-0.09 \\
(0.00)\end{array}$ & $\begin{array}{c}0.05 \\
(0.02)\end{array}$ & $\begin{array}{c}0.01 \\
(0.51)\end{array}$ & $\begin{array}{c}0.04 \\
(0.06)\end{array}$ & $\begin{array}{c}0.31 \\
(0.00)\end{array}$ & $\begin{array}{c}0.06 \\
(0.01)\end{array}$ & $\begin{array}{c}0.21 \\
(0.00)\end{array}$ & 1 & & \\
\hline $\mathbf{A F}$ & 9 & $\begin{array}{l}-0.19 \\
(0.00)\end{array}$ & $\begin{array}{c}0.03 \\
(0.12)\end{array}$ & $\begin{array}{l}-0.04 \\
(0.04)\end{array}$ & $\begin{array}{c}0.08 \\
(0.00)\end{array}$ & $\begin{array}{c}0.67 \\
(0.00)\end{array}$ & $\begin{array}{c}0.55 \\
(0.00)\end{array}$ & $\begin{array}{c}0.68 \\
(0.00)\end{array}$ & $\begin{array}{c}0.63 \\
(0.00)\end{array}$ & 1 & \\
\hline GRId $^{a}$ & 10 & $\begin{array}{l}-0.02 \\
(0.58)\end{array}$ & $\begin{array}{l}-0.10 \\
(0.00)\end{array}$ & $\begin{array}{c}0.06 \\
(0.06)\end{array}$ & $\begin{array}{c}0.20 \\
(0.00)\end{array}$ & - & $\begin{array}{c}0.15 \\
(0.00)\end{array}$ & $\begin{array}{c}0.37 \\
(0.00)\end{array}$ & $\begin{array}{c}0.14 \\
(0.00)\end{array}$ & $\begin{array}{c}0.37 \\
(0.00)\end{array}$ & 1 \\
\hline
\end{tabular}

Notes: This table reports non-parametric Spearman correlation coefficients. For detailed information and definitions of the variables, see Appendix 2 - 1. Reported values: coefficients (p-values). ${ }^{\text {a }}$ GRId (ISS's CG rating) correlations are based on a subsample of 918 voting items (all LF-voting items). GRId ratings are only available for all firms covered by ISS LF-reports.

\section{AGM Voting Characteristics}

Table 2 - 7 provides detailed information on the sample's underlying voting items. It further introduces the distinction between routine and non-routine voting items. ${ }^{38}$ Routine items (e.g., the election of auditors or the discharge of the management or supervisory board) are often seen uncritical by investors and proxy advisors and receive on average lower shareholder dissent than non-routine items. For non-routine items (e.g., votes on significant business

\footnotetext{
${ }^{38}$ However, there is no clear-cut definition available on the distinction between routine and non-routine AGM items. ESMA (2012, p. 19), for example, describes routine and non-routine items in more general terms as follows: "the appointment of auditors may be seen of less importance or concern to investors than more substantive issues like major business decisions or significant corporate governance matters such as director remuneration". Consistent with this, ISS classifies especially the appointment of auditors as a routine item in the German context.
} 
decisions or remuneration packages), opinions about best practice might differ among shareholders and proxy advisors (ESMA, 2012, p. 19).

Table 2 - 7: AGM Voting Characteristics

\begin{tabular}{|c|c|c|c|c|c|}
\hline \multirow[b]{2}{*}{$\begin{array}{l}\text { AGM } \\
\text { Items }\end{array}$} & \multicolumn{2}{|c|}{ All Mgt. Rec } & \multicolumn{2}{|c|}{ ISS Against } & \multirow[b]{2}{*}{ Description of the AGM Items } \\
\hline & $\mathrm{N}$ & $\begin{array}{l}\text { Voting } \\
\text { Result }\end{array}$ & $\mathrm{N}$ & $\begin{array}{l}\text { Voting } \\
\text { Result }\end{array}$ & \\
\hline \multicolumn{6}{|c|}{ Panel A. Routine AGM Mgt. Rec. Items } \\
\hline M0101 & 185 & 98.83 & 1 & 82.88 & Ratify $x$ as Auditors for Fiscal \\
\hline M0105 & 3 & 99.70 & & & Accept Financial Statements and Statutory Reports for Fiscal \\
\hline M0106 & 1 & 99.99 & & & Amend Articles Re: Editorial Changes \\
\hline M0111 & 4 & 98.07 & & & Change Company Name to $x A G$ \\
\hline M0115 & 1 & 100 & & & Allow Electronic Distribution of Company Communications \\
\hline M0126 & 216 & 99.49 & & & $\begin{array}{l}\text { Amend Articles Re: [e.g., due to Law on Transposition of EU Shareholder's Rights } \\
\text { Directive] }\end{array}$ \\
\hline M0152 & 117 & 99.43 & 4 & 95.40 & Approve Allocation of Income and Dividends of EUR x per Share \\
\hline M0159 & 3 & 99.62 & & & Change Location of Registered Office to xy \\
\hline M0260 & 207 & 98.31 & & & Approve Discharge of Management Board for Fiscal \\
\hline M0261 & 224 & 98.19 & 3 & 89.24 & Approve Discharge of Supervisory Board for Fiscal \\
\hline M0267 & 2 & 99.98 & & & Approve Discharge of Personally Liable Partner for Fiscal \\
\hline M0417 & 1 & 98.65 & & & Approve Change of Corporate Form to Societas Europaea (SE) \\
\hline M0459 & 40 & 99.45 & & & Approve Affiliation Agreement with Subsidiary \\
\hline Total1 & 1004 & 98.8 & 8 & 91.5 & \\
\hline
\end{tabular}

Panel B. Non-Routine AGM Mgt. Rec. Items

\begin{tabular}{|c|c|c|c|c|c|}
\hline M0122 & 2 & 99.81 & & & Adopt New Articles of Association \\
\hline M0135 & 9 & 98.35 & 1 & 92.73 & Amend Corporate Purpose \\
\hline M0137 & 5 & 97.02 & 2 & 92.65 & Cancel Special Audit \\
\hline M0203 & 3 & 99.36 & & & Approve Increase in Size of Supervisory Board \\
\hline M0204 & 2 & 99.98 & & & Approve Decrease in Size of Supervisory Board \\
\hline M0212 & 2 & 98.45 & & & Approve Director/Officer Liability and Indemnification \\
\hline M0219 & 41 & 94.31 & & & Approve Remuneration of Supervisory Board \\
\hline M0227 & 23 & 97.98 & 4 & 94.41 & Amend articles re: $D \& O$ insurance for supervisory board members \\
\hline M0228 & 3 & 96.64 & & & Elect xy as Alternate Director to the Supervisory Board \\
\hline M0250 & 200 & 97.47 & 25 & 95.13 & Elect supervisory board member xy \\
\hline M0275 & 2 & 97.99 & 2 & 97.99 & Elect supervisory board members (Bundled) \\
\hline M0318 & 10 & 98.13 & 2 & 99.94 & $\begin{array}{l}\text { Authorize Share Repurchase via Other Channels than Stock Exchange or for trading } \\
\text { purposes }\end{array}$ \\
\hline M0326 & 1 & 99.96 & & & Approve Capitalization of Reserves \\
\hline M0329 & 7 & 97.86 & & & Approve Creation of Pool of Capital with Preemptive Rights \\
\hline M0330 & 4 & 99.23 & & & Approve Cancellation of Pool of Capital or Reduction of Conditional Capital \\
\hline M0331 & 48 & 90.92 & 32 & 88.91 & Approve Creation of Pool of Capital without Preemptive Rights \\
\hline M0333 & 15 & 99.46 & & & Approve Cancellation of Capital Authorization \\
\hline M0346 & 127 & 95.88 & 30 & 89.87 & $\begin{array}{l}\text { Authorize Share Repurchase Program and Reissuance or Cancellation of } \\
\text { Repurchased Shares }\end{array}$ \\
\hline M0358 & 37 & 90.87 & 19 & 86.97 & $\begin{array}{l}\text { Approve Issuance of Warrants/Bonds with Warrants Attached/Convertible Bonds } \\
\text { with Partial Exclusion of Preemptive Rights; Approve Creation of Pool of Capital to } \\
\text { Guarantee Conversion Rights }\end{array}$ \\
\hline M0374 & 3 & 98.87 & & & Approve Reduction in Share Capital via Reverse Stock Split to Cover Losses \\
\hline M0377 & 1 & 99.97 & & & Amend Articles Re: Profit Participation of New Shares \\
\hline M0379 & 14 & 92.78 & 6 & 91.86 & Approve Creation of Capital Pool with Partial Exclusion of Preemptive Rights \\
\hline M0389 & 10 & 94.99 & 7 & 95.49 & Authorize use of financial derivatives when repurchasing shares \\
\hline M0414 & 3 & 99.98 & & & $\begin{array}{l}\text { Approve Change of Personally Liable Partner / Approve Squeeze-Out of Minority } \\
\text { Shareholders by Majority Shareholder }\end{array}$ \\
\hline M0451 & 1 & 99.42 & & & Approve Merger by Absorption of $x A G$ \\
\hline M0454 & 1 & 85.76 & & & Approve Spin-Off Agreements \\
\hline M0501 & 12 & 92.16 & 1 & 98.67 & $\begin{array}{l}\text { Approve stock option plan for key employees; approve creation of capital pool of } \\
\text { conditional capital to guarantee conversion rights }\end{array}$ \\
\hline M0503 & 1 & 99.92 & & & Amend Stock Option Plan \\
\hline M0547 & 15 & 89.42 & 15 & 89.42 & $\begin{array}{l}\text { Authorize Management Board Not to Disclose Individualized Remuneration of its } \\
\text { Members }\end{array}$ \\
\hline M0550 & 58 & 92.13 & 25 & 86.28 & Approve Remuneration System for Management Board Members \\
\hline Total2 & 660 & 95.3 & 171 & 90.2 & \\
\hline $\mathrm{T} 1+\mathrm{T} 2$ & 1664 & 97.4 & 179 & 90.3 & \\
\hline
\end{tabular}

Notes: M0xx values, such as M0101 (ratify auditor), are taken from ISS's proxy voting reports and reflect ISS's way to code and structure AGM items. 
In line with the expectation that routine items are less controversial than non-routine items, Table 2 - 7 reveals a higher shareholder support for routine items than for non-routine items $(98.8 \%$ vs. $95.3 \%)$. Likewise, only 8 out of 179 ISS “vote against" recommendations address routine items. The majority of negative ISS recommendations addresses non-routine issues like board elections (M0250), capital authorizations (M0331, M0346, M0358), and management compensation (M0547, M0550). Consistent with the paper's first prediction, Table 2 - 7 presents further descriptive evidence on the potential influence of ISS recommendations. Specifically, the shareholder dissent for voting items with negative ISS recommendations is substantially higher compared to the overall voting dissent. For example, the average shareholder dissent for all non-routine items is $4.7 \%(100 \%-95.3 \%)$, whereas the dissent for non-routine items with negative ISS recommendations amounts to $9.8 \%(100 \%$ $90.2 \%)$.

\section{Mean Analyses: Voting Result}

Table 2 - 8 provides mean analyses along the dimension of whether ISS recommends to vote for or against specific voting items. Across all different sample compositions (all different panels), the mean voting result is - in line with the paper's first prediction - consistently lower for these voting items which receive negative ISS voting recommendations compared to these with positive recommendations. For example, the difference in the voting result - based on all voting items (1,664 voting items from 185 individual firms) - between voting items with positive and negative ISS recommendations amounts to $7.96 \%$ (Panel A, Table 2 - 8). In addition, voting turnout, free float, and client base appear to moderate the relationship between ISS recommendations and voting dissent. In all subsamples, the voting result for items with negative ISS recommendations decreases. Compared to $98.31 \%$ and $90.35 \%$ in the full sample (Panel A, Table 2 - 8), the mean voting result for voting items with above-average client base (i.e., voting items from LF-reports) and below-average voting turnout amounts to $97.5 \%$ and $81.94 \%$ for voting items with positive and negative ISS recommendations, respectively (Panel F, Table 2 - 8). Although voting turnout, free float, and client base appear to moderate the relationship between ISS recommendations and voting results, they do not vary systematically between positive and negative ISS recommendations. This suggests that ISS's decisions to issue "vote against" recommendations are not affected by voting turnout, free float, or client base. 
Table 2 - 8: Mean Analyses

\begin{tabular}{|c|c|c|c|c|c|c|c|c|}
\hline & \multicolumn{2}{|c|}{$\begin{array}{c}\text { Total Mgt. } \\
\text { Rec. }\end{array}$} & \multicolumn{2}{|c|}{$\begin{array}{c}\text { ISS FOR } \\
\text { Rec. }\end{array}$} & \multicolumn{2}{|c|}{$\begin{array}{c}\text { ISS AGAINST } \\
\text { Rec. } \\
\end{array}$} & \multicolumn{2}{|c|}{$\begin{array}{c}\text { Differences: } \\
\text { AGAINST/FOR }\end{array}$} \\
\hline & Mean & $\mathrm{N}$ & Mean & $\mathrm{N}$ & Mean & $\mathrm{N}$ & Coefficient & p-value \\
\hline \multicolumn{9}{|c|}{ Panel A. All AGM items } \\
\hline VOTING RESULTS & 97.45 & 1664 & 98.31 & 1485 & 90.35 & 179 & $-7.96 * * *$ & 0.000 \\
\hline Turnout & 59.29 & 1664 & 59.04 & 1485 & 61.35 & 179 & 2.30 & 0.193 \\
\hline Free Float & 62.57 & 1664 & 62.77 & 1485 & 60.87 & 179 & -1.90 & 0.396 \\
\hline CLIENT BASE & .5516 & 1664 & .5468 & 1485 & .5921 & 179 & .0453 & 0.249 \\
\hline \multicolumn{9}{|c|}{ Panel B. All non-routine AGM items } \\
\hline VOTING RESULTS & 95.37 & 660 & 97.15 & 489 & 90.29 & 171 & $-6.85 * * *$ & 0.000 \\
\hline Turnout & 60.08 & 660 & 59.58 & 489 & 61.51 & 171 & 1.92 & 0.298 \\
\hline Free Float & 63.77 & 660 & 64.60 & 489 & 61.40 & 171 & -3.19 & 0.185 \\
\hline CLIENT BASE & .5787 & 660 & .5746 & 489 & .5906 & 171 & .0160 & 0.715 \\
\hline \multicolumn{9}{|c|}{ Panel C. All AGM items with below-average TURNOUT } \\
\hline VOTING RESULTS & 96.56 & 796 & 97.67 & 717 & 86.48 & 79 & $-11.19 * * *$ & 0.000 \\
\hline Turnout & 39.78 & 796 & 39.65 & 717 & 40.98 & 79 & 1.33 & 0.418 \\
\hline Free Float & 76.17 & 796 & 76.53 & 717 & 72.88 & 79 & -3.65 & 0.166 \\
\hline CLIENT BASE & .4886 & 796 & .4853 & 717 & .5189 & 79 & .0336 & 0.570 \\
\hline
\end{tabular}

Panel D. All AGM items with above-average FREE FLOAT

\begin{tabular}{lllllllrr}
\hline VOTING RESULTS & $\mathbf{9 6 . 7 9}$ & $\mathbf{8 2 0}$ & $\mathbf{9 7 . 8 2}$ & $\mathbf{7 4 0}$ & $\mathbf{8 7 . 3 5}$ & $\mathbf{8 0}$ & $\mathbf{- 1 0 . 4 6 * * *}$ & $\mathbf{0 . 0 0 0}$ \\
Turnout & 49.03 & 820 & 48.81 & 740 & 51.09 & 80 & 2.28 & 0.367 \\
Free Float & 87.74 & 820 & 87.68 & 740 & 88.35 & 80 & .6675 & 0.657 \\
CLIENT BASE & .5414 & 820 & .5364 & 740 & .5875 & 80 & .0510 & 0.385 \\
\hline
\end{tabular}

Panel E. All AGM items with above-average CLIENT BASE (LF-reports)

\begin{tabular}{lccccccccc}
\hline VOTING RESULTS & $\mathbf{9 6 . 9 9}$ & $\mathbf{9 1 8}$ & $\mathbf{9 8 . 2 1}$ & $\mathbf{8 1 2}$ & $\mathbf{8 7 . 6 0}$ & $\mathbf{1 0 6}$ & $\mathbf{- 1 0 . 6 0 * * *}$ & $\mathbf{0 . 0 0 0}$ \\
Turnout & 60.50 & 918 & 60.24 & 812 & 62.43 & 106 & 2.18 & 0.319 \\
Free Float & 61.78 & 918 & 61.81 & 812 & 61.53 & 106 & -.2799 & 0.917 \\
CLIENT BASE & 1 & 918 & 1 & 812 & 1 & 106 & 0 \\
\hline GRId & $\mathbf{9 . 1 3}$ & $\mathbf{9 1 8}$ & $\mathbf{9 . 1 8}$ & $\mathbf{8 1 2}$ & $\mathbf{8 . 6 9}$ & $\mathbf{1 0 6}$ & $\mathbf{- . 4 8 9 0 * * *}$ & $\mathbf{0 . 0 0 0}$ \\
\hline
\end{tabular}

Panel F. All AGM items with above-average CLIENT BASE (LF-reports) \& below-average TURNOUT

\begin{tabular}{lcccccccc}
\hline VOTING RESULTS & $\mathbf{9 5 . 8 6}$ & $\mathbf{3 8 9}$ & $\mathbf{9 7 . 5 0}$ & $\mathbf{3 4 8}$ & $\mathbf{8 1 . 9 4}$ & $\mathbf{4 1}$ & $\mathbf{- 1 5 . 5 6 * * *}$ & $\mathbf{0 . 0 0 0}$ \\
Turnout & 39.62 & 389 & 39.37 & 348 & 41.69 & 41 & 2.32 & 0.271 \\
Free Float & 79.50 & 389 & 79.98 & 348 & 75.41 & 41 & -4.57 & 0.162 \\
CLIENT BASE & 1 & 389 & 1 & 348 & 1 & 41 & 0 & - \\
\hline GRId & $\mathbf{9 . 2 1}$ & $\mathbf{3 8 9}$ & $\mathbf{9 . 2 4}$ & $\mathbf{3 4 8}$ & $\mathbf{7 5 . 4 1}$ & $\mathbf{4 1}$ & $\mathbf{- . 2 4 4}$ & $\mathbf{0 . 1 8 4}$ \\
\hline
\end{tabular}

Panel G. All AGM items with above-average CLIENT BASE (LF-reports) \& above-average FREE FLOAT

\begin{tabular}{lcccccccc}
\hline VOTING RESULTS & $\mathbf{9 6 . 1 4}$ & $\mathbf{4 4 4}$ & $\mathbf{9 7 . 6 3}$ & $\mathbf{3 9 7}$ & $\mathbf{8 3 . 5 4}$ & $\mathbf{4 7}$ & $\mathbf{- 1 4 . 0 8 * * *}$ & $\mathbf{0 . 0 0 0}$ \\
Turnout & 48.15 & 444 & 47.53 & 397 & 53.41 & 47 & $5.88^{* *}$ & 0.040 \\
Free Float & 85.18 & 444 & 84.93 & 397 & 87.25 & 47 & 2.32 & 0.251 \\
CLIENT BASE & 1 & 444 & 1 & 397 & 1 & 47 & 0 \\
\hline GRId & $\mathbf{9 . 3 3}$ & $\mathbf{4 4 4}$ & $\mathbf{9 . 4 2}$ & $\mathbf{3 9 7}$ & $\mathbf{8 . 5 3}$ & $\mathbf{4 7}$ & $\mathbf{- . 8 9 6 2 * * *}$ & $\mathbf{0 . 0 0 0}$ \\
\hline
\end{tabular}

Panel H. All AGM items with below-average TURNOUT \& above-average FREE FLOAT

\begin{tabular}{llllllccc}
\hline VOTING RESULTS & $\mathbf{9 6 . 2 1}$ & $\mathbf{5 7 4}$ & $\mathbf{9 7 . 4 9}$ & $\mathbf{5 2 2}$ & $\mathbf{8 3 . 2 9}$ & $\mathbf{5 2}$ & $\mathbf{- 1 4 . 2 0 * * *}$ & $\mathbf{0 . 0 0 0}$ \\
Turnout & 37.72 & 574 & 37.77 & 522 & 37.22 & 52 & -.5506 & 0.773 \\
Free Float & 88.15 & 574 & 88.29 & 522 & 86.75 & 52 & -1.54 & 0.370 \\
CLIENT BASE & .5452 & 574 & .5440 & 522 & .5576 & 52 & .0136 & 0.851 \\
\hline
\end{tabular}

Panel I. All AGM items with below-average TURNOUT \& above-average FREE FLOAT \& above-average CLIENT BASE (LF-reports)

\begin{tabular}{lcccccccc}
\hline VOTING RESULTS & $\mathbf{9 5 . 6 1}$ & $\mathbf{3 1 3}$ & $\mathbf{9 7 . 4 5}$ & $\mathbf{2 8 4}$ & $\mathbf{7 7 . 5 8}$ & $\mathbf{2 9}$ & $\mathbf{- 1 9 . 8 6 * * *}$ & $\mathbf{0 . 0 0 0}$ \\
Turnout & 38.76 & 313 & 38.69 & 284 & 39.49 & 29 & .8058 & 0.733 \\
Free Float & 87.51 & 313 & 87.58 & 284 & 86.82 & 29 & -.7533 & 0.749 \\
CLIENT BASE & 1 & 313 & 1 & 284 & 1 & 29 & 0 & - \\
\hline GRId & $\mathbf{9 . 2 9}$ & $\mathbf{3 1 3}$ & $\mathbf{9 . 3 0}$ & $\mathbf{2 8 4}$ & $\mathbf{9 . 1 7}$ & $\mathbf{2 9}$ & $\mathbf{- . 1 3 7 4}$ & $\mathbf{0 . 5 0 8}$ \\
\hline
\end{tabular}

Notes: This table presents distribution characteristics (mean, N) of VOTING RESULTS, Turnout, Free Float, and CLIENT BASE (and GRId only for LF-report samples) based on different sample compositions and along the dimension of whether or not ISS recommends to vote in favor of management proposals or not. For detailed descriptions of the variables, see Appendix $2-1$. The significance tests are based on t-test statistics. $*^{* *}(* *)(*)$ indicates a significance level at 1\% (5\%) (10\%), two-tailed. 
With respect to the paper's second prediction, Table 2 - 8 provides further descriptive evidence on ISS method consistency (i.e., the relation between ISS voting recommendations and ISS governance rating). As ISS governance ratings (GRId) are only available for firms which are covered by ISS LF-reports, mean values of GRId are only examined for the LFsubsamples (Panel E, F, G, and I). In particular, ISS governance ratings (GRId) are consistently higher for voting items / firms with positive ISS recommendations across all analyzed subsamples. For example, based on the subsample of firms which are covered by ISS LF-reports (918 voting items from 92 individual firms), the GRId rating is on average higher - with 0.49 points - for voting items / firms with positive ISS recommendations compared to these with negative recommendations (Panel E, Table 2 - 8). However, the differences in the GRId rating are only significant in two out of four cases.

Figure 2 - 1: Mean Analyses

\section{Panel A. ISS Recommendations and Voting Dissent}

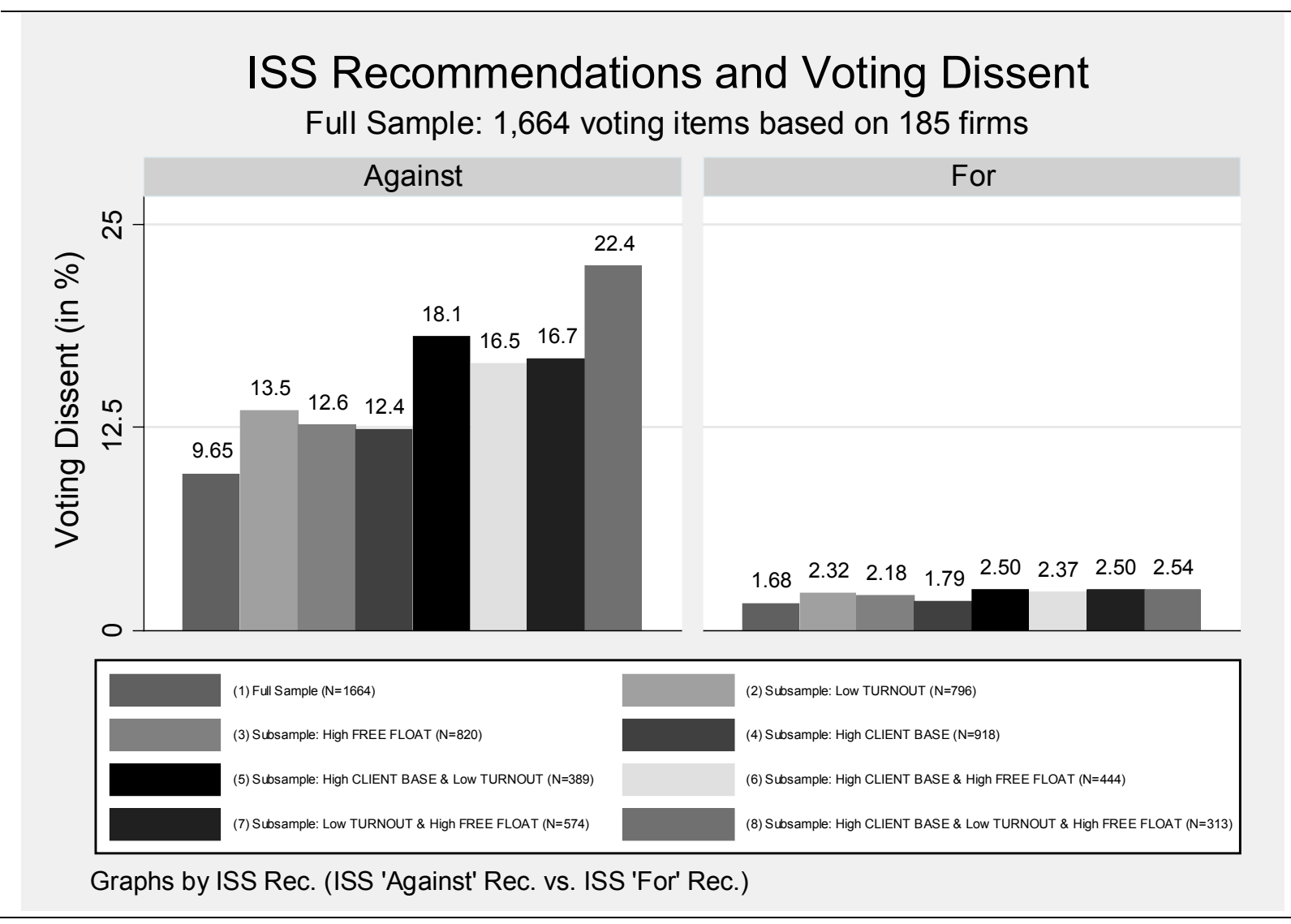


Figure 2 - 1: Mean Analyses (continued)

Panel B. ISS Recommendations and Firm Characteristics

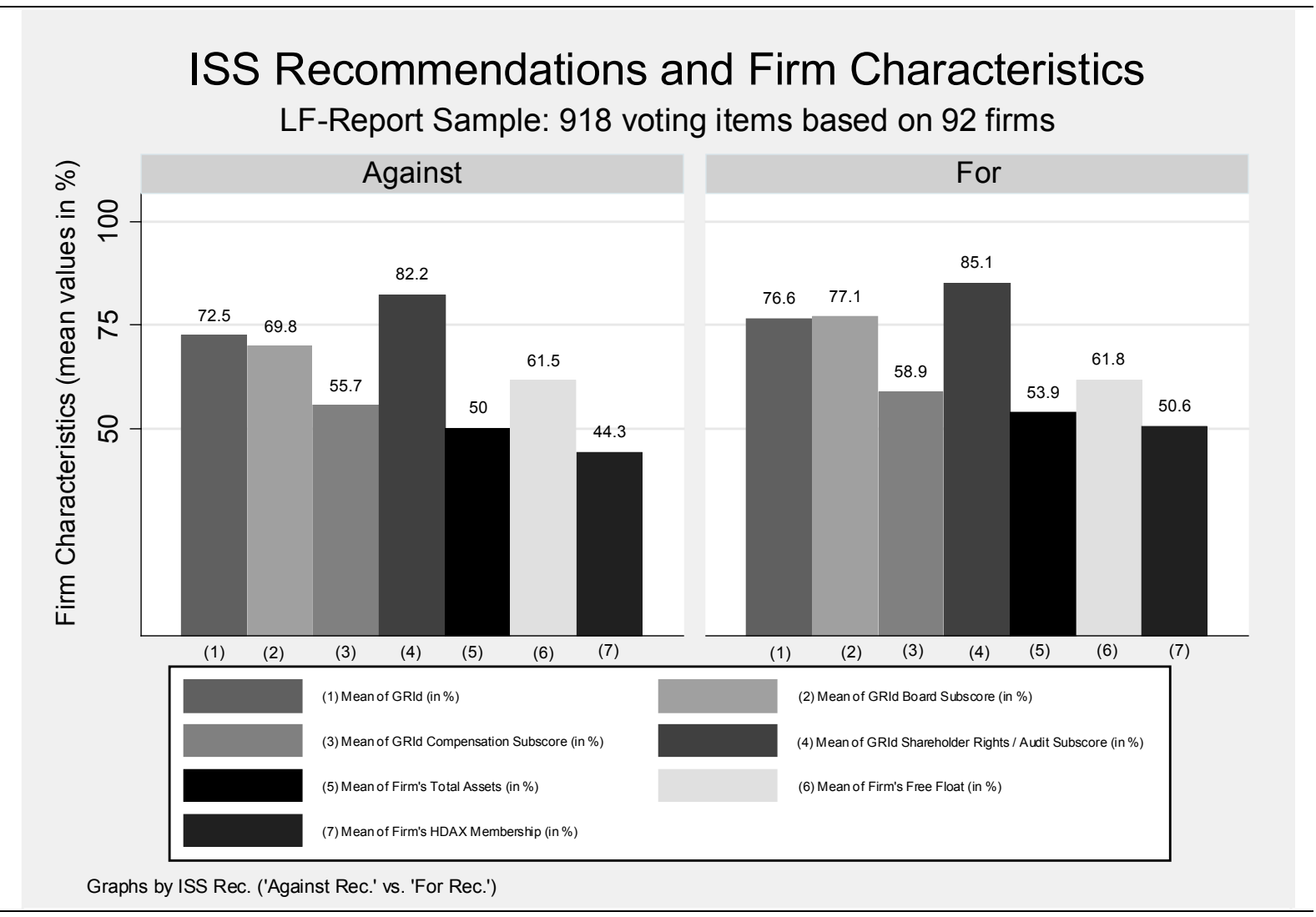

Figure 2 - 1 complements the mean analyses. It visualizes the increasing voting dissent for negative ISS recommendations along the different sample compositions (along the different subsamples with respect to voting turnout, free float, and client base). In contrast to this, the mean voting dissent for voting items with positive ISS recommendations remains rather constant at a level of around 2\%. In addition, Panel B of Figure 2 - 1 highlights that the overall governance rating (GRId) as well as the different subscores (with respect to board, compensation, shareholder rights, and audit issues) are higher for voting items / firms with positive ISS voting recommendations compared to these with negative recommendations.

\subsubsection{Regression Results}

\section{Proxy Voting Recommendations and Voting Outcomes}

Table 2 - 9 provides regression results. In line with the paper's first prediction and consistent with the descriptive results discussed above, Model 1 shows that negative ISS recommendations correlate with $8.5 \%$ less supportive shareholder votes. This drop is even 
more pronounced when considering voting items with high client base $(11.21 \%)$, low voting turnout $(11.59 \%)$, and high free float $(11.44 \%) .{ }^{39}$ In addition, when examining the subsample of firms which are covered by ISS LF-reports (i.e., firms with above-average client base), ISS recommendations correlate with $16.32 \%$ and $16.11 \%$ less supportive shareholder votes for voting items with below-average turnout and above average free float, respectively (Models 5 and 6, Panel A, Table 2 - 9). ${ }^{40}$ These results indicate that ISS voting recommendations significantly correlate with shareholder votes on a statistically as well as economically meaningful level. Overall, they suggest that - despite differences in the institutional arrangements between the U.S. and Germany - proxy voting advisors might play an influential role at German AGMs as well. In economic terms, however, ISS voting recommendations correlate with voting outcomes at a comparably lower level $(8.5 \%$ to $19 \%$ and 26\% as documented by Cai et al., 2009 and Ertimur et al., 2013, respectively).

Table 2 - 9: Regression Results: Prediction 1 - Firm-Fixed-Effects Regressions

\begin{tabular}{|c|c|c|c|c|c|c|c|}
\hline & \multirow{3}{*}{$\begin{array}{l}\text { Pred. } \\
\text { Sign }\end{array}$} & \multicolumn{6}{|c|}{ Dependent Variable: VOTING RESULT (in \%) } \\
\hline & & \multicolumn{4}{|c|}{$\begin{array}{c}\text { Full Sample } \\
\text { (LF- and SF- ISS reports) }\end{array}$} & \multicolumn{2}{|c|}{$\begin{array}{c}\text { LF-Sample } \\
\text { (N with high Client Base) }\end{array}$} \\
\hline & & Model 1 & Model 2 & Model 3 & Model 4 & Model 5 & Model 6 \\
\hline MODERATOR & & - & CLIENT BASE & INVTURNOUT & FREE FLOAT & INVTURNOUT & FREE FLOAT \\
\hline Intercept & & $\begin{array}{c}98.370 * * * \\
(344.36)\end{array}$ & $\begin{array}{c}98.376^{* * *} \\
(350.16)\end{array}$ & $\begin{array}{c}98.278^{* * *} \\
(260.71)\end{array}$ & $\begin{array}{c}98.373 * * * \\
(347.37)\end{array}$ & $\begin{array}{c}98.242^{* * *} \\
(214.20)\end{array}$ & $\begin{array}{c}98.302 * * * \\
(293.31)\end{array}$ \\
\hline ISS AGAINST & - & $\begin{array}{c}-8.471 * * * \\
(-9.35)\end{array}$ & $\begin{array}{c}-4.623 * * * \\
(-6.13)\end{array}$ & $\begin{array}{c}-5.830 * * * \\
(-9.84)\end{array}$ & $\begin{array}{c}-6.114 * * * \\
(-9.01)\end{array}$ & $\begin{array}{c}-7.943 * * * \\
(-6.88)\end{array}$ & $\begin{array}{c}-7.569 * * * \\
(-6.62)\end{array}$ \\
\hline MODERATOR & & & & $\begin{array}{l}0.189 \\
(0.55)\end{array}$ & & $\begin{array}{l}0.105 \\
(0.20)\end{array}$ & \\
\hline ISS $\times$ MODERATOR & - & & $\begin{array}{c}-6.590 * * * \\
(-3.19)\end{array}$ & $\begin{array}{l}-5.950 * * * \\
(-5.77)\end{array}$ & $\begin{array}{c}-5.33 * * * \\
(-3.39)\end{array}$ & $\begin{array}{c}-8.483 * * * \\
(-4.37)\end{array}$ & $\begin{array}{c}-8.542 * * * \\
(-2.96)\end{array}$ \\
\hline $\mathrm{N}$ & & 1664 & 1664 & 1664 & 1664 & 918 & 918 \\
\hline Adj. $R^{2}$ & & .3142 & .3354 & .3312 & .3281 & .4838 & .4860 \\
\hline $\begin{array}{l}\text { Linear Prediction of Voting } \\
\text { (a) ISS }=1 \& \text { Moderator }=0 \\
\text { (b) ISS }=1 \& \text { Moderator }=1\end{array}$ & sult (in & & $\begin{array}{l}93.75 \\
87.16\end{array}$ & $\begin{array}{l}92.44 \\
86.68\end{array}$ & $\begin{array}{l}92.25 \\
86.92\end{array}$ & $\begin{array}{l}90.29 \\
81.92\end{array}$ & $\begin{array}{l}90.73 \\
82.19\end{array}$ \\
\hline
\end{tabular}

Notes: Underlying regression model is:

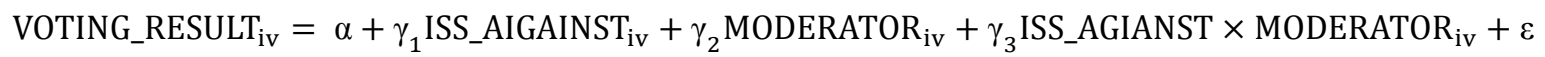

The dependent variable VOTING_RESULT ${ }_{\text {iv }}$ stands for the voting result (in \%) casted in favor of a specific voting item of firm i and AGM voting item v. ISS_AGAINST is a variable indicating with 1 if ISS recommends to vote against a specific AGM item, and zero otherwise. MODERATOR stands for different variables which are expected to moderate the relationship between ISS "vote against" recommendations and voting results, i.e., FREE FLOAT (with one if firm's free float is above average, and zero otherwise), invTURNOUT (with one if firm's voting presence is below average, and zero otherwise), and CLIENT BASE (with one if firm is covered by ISS LF-report, and zero otherwise). The regression models have robust standard errors which are one-way clustered at AGM voting item level. To control for (observed / unobserved) firm characteristics the regression models contain firm-fixed effects. For detailed descriptions of the variables, see Appendix 2 - 1 . Reported values: coefficient (t-value) $* * *(* *)(*)$ indicates a significance level at 1\%(5\%) (10\%), two-tailed.

\footnotetext{
${ }^{39}$ Except for invTURNOUT, firm fixed-effects capture the main effects of FREE FLOAT and CLIENT BASE.

${ }^{40}$ To shed further light on the potential moderating effects of client base, free float, and voting turnout, I extend the basic regression model with twofold interaction terms. Untabulated results reveal that ISS voting recommendations correlate with $18.56 \%$ less supportive shareholder votes for voting items with high client base, low voting turnout, and high free float.
} 


\section{Proxy Voting Recommendations and Governance Ratings}

Table 2 - 10 addresses the paper's second prediction and provides the results of the corresponding probit regressions. Across all different models, ISS governance ratings (GRId) significantly correlate with ISS decisions to issue negative voting recommendations. In contrast to this, two out of three control variables, i.e., ownership structure and blue chip index membership, remain insignificant across most models. Besides the statistical significance ( $p$-values are consistently below 1\%), the GRId correlations are economically meaningful. For example, an increase from the lowest to the highest rated firm (an increase from 5 to 12 in the GRId) reduces the probability of receiving a negative ISS recommendation by more than 20 percentage points (Model 1, Table $2-10) .{ }^{41}$ This is even more pronounced with a reduction of over 50 percentage points - when considering a subsample of only nonroutine voting items (Model 2, Table 2 - 10). In addition, Model 3 and 4 (Model 5 and 6) provide corresponding regression results on a subsample of voting items with respect to board elections (compensation issues). If ISS consistently evaluates the board quality as well as the quality of the remuneration system across its voting recommendations and its commercially available governance ratings, one might expect significant correlations especially for the respective subratings GRId_BOARD and GRId_COMP.

Consistent with this, Model 4 (Model 6) shows that ISS recommendations against the election of supervisory board members (against compensation issues) are significantly correlated with ISS's evaluations of the corresponding board quality (the remuneration system's quality). For example, the predicted probability of receiving a "vote against" recommendation by ISS on director election (compensation) proposals is $58.19 \%(66.98 \%)$ and $8.63 \%(1.29 \%)$ for firms with the lowest and the highest board (compensation) score, respectively. ${ }^{42}$ Overall, these findings contrast the U.S. results provided by Daines et al. (2010) and suggest that the employed governance perception of ISS is potentially consistent across its different commercially available products.

One reason for the divergent results might rest upon the different time frames and the different employed ISS governance ratings. In contrast to the U.S. findings provided by Daines et al. (2010) which are based on ISS CGQ ratings, this study employs ISS GRId governance ratings. From 2002 until 2009, ISS's governance ratings were marketed as

\footnotetext{
${ }^{41}$ The final rating score, GRId score, ranges theoretically (empirically for my sample) between 0 (5) and 12 (12). Higher GRId scores indicate better governance quality.

${ }^{42}$ Both scores have numbers between 1 and 3, with higher scores reflecting better governance.
} 
Corporate Governance Quotient (CGQ). In 2010, ISS re-launched the rating under the name Governance Risk Indicator (GRId). However, Larcker and Tayan (2011, p. 440) note that the GRId rating is not materially different to the CGQ rating. Nevertheless, the alignment between both, the methodology of ISS governance ratings and the underlying principles of ISS proxy voting policies, might have increased after 2010. Although ISS already attributes a general alignment between its governance ratings and its proxy voting guidelines prior to the re-launch in 2010 (ISS, 2007, p. 24), it explicitly highlights the alignment between both products afterwards. In particular, ISS / RiskMetrics Group (2010, p. 7) states that "GRId's methodology for assessing risk is closely aligned with the principles underlying RiskMetrics' benchmark proxy voting guidelines". ${ }^{43}$ In addition, it (2010, p. 7) further outlines that this alignment "will help [to] shape GRId, ensuing it is up-to-date, relevant, and tailored to address variations in governance practices across global capital markets".

Table 2 - 10: Regression Results: Prediction 2 - Probit Regressions

\begin{tabular}{|c|c|c|c|c|c|c|c|}
\hline & \multirow{3}{*}{$\begin{array}{l}\text { Pred. } \\
\text { Sign }\end{array}$} & \multicolumn{6}{|c|}{ Dependent Variable: $\boldsymbol{I S S} \boldsymbol{A G A I N S T}$} \\
\hline & & \multirow{2}{*}{$\begin{array}{c}\text { All } \\
\text { AGM items } \\
\text { Model } 1\end{array}$} & \multirow{2}{*}{$\begin{array}{c}\text { Non-routine } \\
\text { AGM items } \\
\text { Model } 2\end{array}$} & \multicolumn{2}{|c|}{$\begin{array}{c}\mathrm{M} 0228 / \mathrm{M} 0250 / \mathrm{M} 0275 \\
\text { (board elections) }\end{array}$} & \multicolumn{2}{|c|}{$\begin{array}{c}\text { M0219/M0547/M0550 } \\
\text { (compensation) }\end{array}$} \\
\hline & & & & Model 3 & Model 4 & Model 5 & Model 6 \\
\hline Intercept & & $\begin{array}{l}1.171^{*} \\
(1.65)\end{array}$ & $\begin{array}{c}3.300 * * * \\
(4.44)\end{array}$ & $\begin{array}{c}5.324 * * \\
(2.17)\end{array}$ & $\begin{array}{c}4.915 * * \\
(2.21)\end{array}$ & $\begin{array}{c}5.524 * * * \\
(3.01)\end{array}$ & $\begin{array}{c}4.349 * * \\
(2.47)\end{array}$ \\
\hline GRId & - & $\begin{array}{c}-0.157 * * * \\
(-3.24)\end{array}$ & $\begin{array}{c}-0.253 * * * \\
(-4.52)\end{array}$ & $\begin{array}{c}-0.355 * * * \\
(-3.84)\end{array}$ & & $\begin{array}{c}-0.966 * * * \\
(-4.48)\end{array}$ & \\
\hline GRId_BOARD & - & & & & $\begin{array}{c}-0.834 * * * \\
(-2.95)\end{array}$ & & $\begin{array}{c}-0.852 * * * \\
(-2.97)\end{array}$ \\
\hline GRId_COMP & - & & & & $\begin{array}{l}0.110 \\
(0.37)\end{array}$ & & $\begin{array}{c}-2.038 * * * \\
(-5.11)\end{array}$ \\
\hline GRId_SR\&AUDIT & & & & & $\begin{array}{l}-0.183 \\
(-0.69)\end{array}$ & & $\begin{array}{c}-0.666^{* *} \\
(-2.31)\end{array}$ \\
\hline SIZE $(\log$ of TA) & & $\begin{array}{l}-0.073^{*} \\
(-1.71)\end{array}$ & $\begin{array}{l}-0.113 * * \\
(-2.59)\end{array}$ & $\begin{array}{l}-0.191 \\
(-1.37)\end{array}$ & $\begin{array}{l}-0.215 \\
(-1.52)\end{array}$ & $\begin{array}{c}0.212^{*} \\
(1.86)\end{array}$ & $\begin{array}{l}0.298 * * \\
(2.47)\end{array}$ \\
\hline Free Float & & $\begin{array}{l}-0.000 \\
(-0.07)\end{array}$ & $\begin{array}{l}-0.001 \\
(-0.42)\end{array}$ & $\begin{array}{l}-0.005 \\
(-0.84)\end{array}$ & $\begin{array}{l}-0.005 \\
(-0.83)\end{array}$ & $\begin{array}{l}-0.017 * * \\
(-2.03)\end{array}$ & $\begin{array}{c}-0.023 * * \\
(-2.21)\end{array}$ \\
\hline HDAX & & $\begin{array}{l}0.111 \\
(0.78)\end{array}$ & $\begin{array}{l}0.124 \\
(0.66)\end{array}$ & $\begin{array}{l}0.422 \\
(1.25)\end{array}$ & $\begin{array}{l}0.546 \\
(1.60)\end{array}$ & $\begin{array}{l}0.994 * * \\
(2.27)\end{array}$ & $\begin{array}{l}1.386 * * * \\
(2.69)\end{array}$ \\
\hline IND fixed-effects & & Yes & No & No & No & No & No \\
\hline $\begin{array}{l}\mathrm{N} \\
\text { Pseudo } \mathrm{R}^{2}\end{array}$ & & $\begin{array}{c}918 \\
0.0275\end{array}$ & $\begin{array}{c}382 \\
0.0720\end{array}$ & $\begin{array}{c}117 \\
0.1517\end{array}$ & $\begin{array}{c}117 \\
0.2130\end{array}$ & $\begin{array}{c}75 \\
0.3466\end{array}$ & $\begin{array}{c}75 \\
0.4570\end{array}$ \\
\hline $\begin{array}{l}\text { Predictive Margins if } \\
\text { (a) GRId }=5 \\
\text { (b) GRId }=9.13 \\
\text { (c) GRId }=12 \\
\text { (d) GRId_Board }=1 \\
\text { (e) GRId_Board }=2 \\
\text { (f) GRId_Board }=3 \\
\text { (g) GRId_Comp }=1 \\
\text { (h) GRId_Comp }=2 \\
\text { (i) GRId_Comp }=3\end{array}$ & & $\begin{array}{l}.2824 \\
.1111 \\
.0476\end{array}$ & $\begin{array}{l}.6509 \\
.2617 \\
.0881\end{array}$ & $\begin{array}{l}.7489 \\
.2290 \\
.0422\end{array}$ & $\begin{array}{l}.5819 \\
.2818 \\
.0863\end{array}$ & $\begin{array}{l}.9940 \\
.3117 \\
.0026\end{array}$ & $\begin{array}{l}.6698 \\
.2099 \\
.0129\end{array}$ \\
\hline
\end{tabular}

Notes: Underlying regression is:

ISS_AGAINST $_{\text {iv }}=\alpha+\gamma_{1} \operatorname{GRId}_{\text {iv }}\left(\sum \gamma_{1}\right.$ GRId_SUBSCORES $\left._{\text {iv }}\right)+\sum \gamma_{2}$ FIRM_CONTROL $_{\text {iv }}+\sum \gamma_{3}$ IND $_{\text {iv }}+\varepsilon$

\footnotetext{
${ }^{43}$ Until the acquisition by MSCI in 2010, ISS was a subsidiary of RiskMetrics Group. In April 2014, ISS was acquired by Vestar Capital Partners.
} 
The dependent variable ISS AGAINST is a dummy variable indicating with 1 if ISS recommends to vote against a specific voting item, and 0 otherwise. GRId (Governance Risk Indicator) stands for ISS's commercial corporate governance rating. GRId_SUBSCORES reflects the different subscores of the commercial corporate governance rating (i.e., subscores for board, compensation, shareholder rights, and audits). FIRM_CONTROL is a vector of different firm-level control variables (log of total assets, free float, and blue chip (HDAX) index membership). IND stands for industry-fixed effects. The regression models have standard errors which are heteroskedasticity robust and one-way clustered at firm level. For detailed descriptions of the variables, see Appendix 2 - 1. Reported values: coefficient (t-value) *** $(* *)(*)$ indicates a significance level at $1 \%(5 \%)$ $(10 \%)$, two-tailed.

\subsubsection{Additional Analyses}

\section{Sample Selection Bias}

I perform several analyses to test the robustness of my findings. First, I address potential sample selection problems due to the limited availability of ISS reports. As outlined in section 2.5.1, the TRAA database only provides ISS voting reports for firms with shareholder meetings in the period between May and December 2010. Thus, my sample might be to some extent selected by smaller firms as these firms tend to have larger audit delays and consequently later shareholder meetings (e.g., Hitz et al., 2013). The descriptive results in Table 2 - 5 support this presumption. Specifically, they reveal that the final sample 'only' covers 6 out of 30 DAX firms, 21 out of 50 MDAX firms, and 16 out of 30 TecDAX firms. To shed light on this selection problem, I compare - in a first step and on a descriptive level the sample's voting characteristics with these of the largest German firms (with all DAX and MDAX firms). In a second step, I perform probit regressions to directly address the differences between my final selected sample and the corresponding ISS universe (i.e., the German firms which are covered by ISS during the proxy season 2010). ${ }^{44}$

Table 2 - 11 presents the results. Especially, firms covered by ISS LF-reports do not appear to differ from DAX and MDAX firms with respect to AGM voting characteristics (Panel A of Table 2 - 11). For example, the average shareholders' attendance rate $(60.5 \% \mathrm{vs}$. $60.5 \%)$ and the average voting dissent (3.2\% vs. 3.01\%) are fairly similar. Likewise, the average voting results are on a comparable level across the different voting items. With respect to firm-level characteristics, Panel B of Table 2 - 11 provides different probit regressions based on Worldscope and ISS firm universe. In particular, the first two models examine directly the selection of ISS reports in the TRAA database (N=279) with respect to the ISS (Model 1) and Worldscope (Model 2) firm universe.

\footnotetext{
${ }^{44}$ To identify the ISS proxy voting universe, I use detailed coverage data provided directly by ISS.
} 
Table 2 - 11: Sample Selection Bias

Panel A. Sample Selection - Comparison with ISS 2010 Voting Report

\begin{tabular}{|c|c|c|c|}
\hline German Proxy Season 2010 & $\begin{array}{c}\text { ISS } 2010 \\
\text { Voting Report: } \\
\text { Germany }^{45} \\
\end{array}$ & $\begin{array}{c}\text { LF-Sample } \\
\text { (92 firms and } 918 \\
\text { voting items) } \\
\end{array}$ & $\begin{array}{c}\text { SF-Sample } \\
\text { (93 firms and } 746 \\
\text { voting items) }\end{array}$ \\
\hline \multicolumn{4}{|l|}{ AGM Characteristics } \\
\hline Shareholders' attendance rate at AGMs & $60.5 \%$ & $60.5 \%$ & $57.8 \%$ \\
\hline Average dissent at AGMs & $3.2 \%$ & $3.01 \%$ & $1.96 \%$ \\
\hline \multicolumn{4}{|l|}{ Voting results for specific items } \\
\hline (1) Dividend and profit allocation & $99.6 \%$ & $99.35 \%$ & $99.55 \%$ \\
\hline (2) Discharge of the boards & $98.3 \%$ & $98.38 \%$ & $98.11 \%$ \\
\hline (3) Nomination of new board members & $97.2 \%$ & $97.46 \%$ & $97.47 \%$ \\
\hline (4) Auditor appointment & $99.0 \%$ & $99.08 \%$ & $98.57 \%$ \\
\hline (5) Capital authorization & $93.3 \%$ & $90.58 \%$ & $97.13 \%$ \\
\hline (6) Share repurchase programs & $95.0 \%$ & $95.29 \%$ & $97.12 \%$ \\
\hline (7) Amendments of articles of association & $99.0 \%$ & $99.13 \%$ & $99.65 \%$ \\
\hline (8) Remuneration proposals & $92.4 \%$ & $91.67 \%$ & $95.88 \%$ \\
\hline
\end{tabular}

Panel B. Sample Selection - Probit Regression

\begin{tabular}{|c|c|c|c|c|c|c|}
\hline & \multirow{2}{*}{\multicolumn{2}{|c|}{$\begin{array}{c}\text { DV: Indicator Variable } \\
\text { (ISS Reports available } \\
\text { in TRAA) }\end{array}$}} & \multirow{2}{*}{\multicolumn{2}{|c|}{$\begin{array}{c}\text { DV: Indicator Variable } \\
\text { (ISS Reports usable } \\
\text { in Sample) }\end{array}$}} & \multicolumn{2}{|c|}{ DV: Indicator Variable } \\
\hline & & & & & $\begin{array}{c}\text { (usable LF } \\
\text { Reports) }\end{array}$ & $\begin{array}{c}\text { (usable SF } \\
\text { Reports) }\end{array}$ \\
\hline & $\begin{array}{l}\text { Model } 1 \\
\text { (N based on } \\
\text { ISS Universe) }\end{array}$ & $\begin{array}{l}\text { Model } 2 \\
\text { (N based on } \\
\text { WS Universe) }\end{array}$ & $\begin{array}{l}\text { Model } 3 \\
\text { (N based on } \\
\text { ISS Universe) }\end{array}$ & $\begin{array}{l}\text { Model } 4 \\
\text { (N based on } \\
\text { WS Universe) }\end{array}$ & $\begin{array}{c}\text { Model } 5 \\
\text { (N based on } \\
\text { ISS Universe) }\end{array}$ & $\begin{array}{l}\text { Model } 6 \\
\text { (N based on } \\
\text { ISS Universe) }\end{array}$ \\
\hline Intercept & $\begin{array}{c}3.840 * * * \\
(4.85)\end{array}$ & $\begin{array}{c}-2.266 * * * \\
(-6.01)\end{array}$ & $\begin{array}{l}-0.148 \\
(-0.24)\end{array}$ & $\begin{array}{c}-3.002 * * * \\
(-7.34)\end{array}$ & $\begin{array}{c}-2.581 * * * \\
(-3.96)\end{array}$ & $\begin{array}{l}0.759 \\
(1.03)\end{array}$ \\
\hline SIZE (log of TA) & $\begin{array}{c}-0.172 * * * \\
(-3.00)\end{array}$ & $\begin{array}{c}0.181 * * * \\
(7.19)\end{array}$ & $\begin{array}{l}0.011 \\
(0.24)\end{array}$ & $\begin{array}{c}0.196 * * * \\
(7.16)\end{array}$ & $\begin{array}{c}0.115^{* *} \\
(2.33)\end{array}$ & $\begin{array}{l}-0.084 \\
(-1.45)\end{array}$ \\
\hline BTM & $\begin{array}{c}0.006 \\
(0.21)\end{array}$ & $\begin{array}{l}-0.003 \\
(-0.51)\end{array}$ & $\begin{array}{l}0.024 \\
(1.08)\end{array}$ & $\begin{array}{l}-0.001 \\
(-0.26)\end{array}$ & $\begin{array}{l}-0.021 \\
(-0.85)\end{array}$ & $\begin{array}{l}0.038 \\
(1.64)\end{array}$ \\
\hline ROA & $\begin{array}{l}-0.074 \\
(-0.28)\end{array}$ & $\begin{array}{l}-0.104 \\
(-1.48)\end{array}$ & $\begin{array}{l}0.111 \\
(0.62)\end{array}$ & $\begin{array}{l}-0.100 \\
(-1.29)\end{array}$ & $\begin{array}{l}0.516 \\
(1.53)\end{array}$ & $\begin{array}{l}-0.010 \\
(-0.06)\end{array}$ \\
\hline HDAX & $\begin{array}{l}0.360 \\
(1.30)\end{array}$ & $\begin{array}{l}-0.127 \\
(-0.47)\end{array}$ & $\begin{array}{l}0.268 \\
(0.98)\end{array}$ & $\begin{array}{l}0.017 \\
(0.06)\end{array}$ & $\begin{array}{c}0.588^{*} \\
(1.89)\end{array}$ & $\begin{array}{c}-0.698^{*} \\
(-1.70)\end{array}$ \\
\hline $\mathrm{AF}$ & $\begin{array}{c}-0.026^{*} \\
(-1.66)\end{array}$ & $\begin{array}{l}-0.018 \\
(-1.32)\end{array}$ & $\begin{array}{l}-0.022 \\
(-1.46)\end{array}$ & $\begin{array}{l}-0.010 \\
(-0.71)\end{array}$ & $\begin{array}{l}-0.020 \\
(-1.20)\end{array}$ & $\begin{array}{c}-0.052 * * \\
(-2.08)\end{array}$ \\
\hline MEETING_JanJun & $\begin{array}{c}-1.489 * * * \\
(-4.35)\end{array}$ & & $\begin{array}{l}-0.060 \\
(-0.35)\end{array}$ & & $\begin{array}{c}0.316 \\
(1.49)\end{array}$ & $\begin{array}{l}-0.186 \\
(-1.03)\end{array}$ \\
\hline IND2 & $\begin{array}{c}0.543 \\
(1.43)\end{array}$ & $\begin{array}{l}-0.050 \\
(-0.18)\end{array}$ & $\begin{array}{l}-0.183 \\
(-0.52)\end{array}$ & $\begin{array}{l}-0.134 \\
(-0.45)\end{array}$ & $\begin{array}{c}-0.048 \\
(-0.11)\end{array}$ & $\begin{array}{c}-0.292 \\
(-0.68)\end{array}$ \\
\hline IND3 & $\begin{array}{l}0.078 \\
(0.22)\end{array}$ & $\begin{array}{l}-0.072 \\
(-0.28)\end{array}$ & $\begin{array}{l}-0.216 \\
(-0.66)\end{array}$ & $\begin{array}{l}-0.020 \\
(-0.07)\end{array}$ & $\begin{array}{l}0.046 \\
(0.12)\end{array}$ & $\begin{array}{l}-0.380 \\
(-0.97)\end{array}$ \\
\hline IND4 & $\begin{array}{l}0.357 \\
(0.87)\end{array}$ & $\begin{array}{l}-0.363 \\
(-1.19)\end{array}$ & $\begin{array}{l}0.017 \\
(0.04)\end{array}$ & $\begin{array}{l}-0.199 \\
(-0.61)\end{array}$ & $\begin{array}{l}0.150 \\
(0.34)\end{array}$ & $\begin{array}{l}-0.228 \\
(-0.49)\end{array}$ \\
\hline IND5 & $\begin{array}{l}-0.120 \\
(-0.28)\end{array}$ & $\begin{array}{l}-0.307 \\
(-0.92)\end{array}$ & $\begin{array}{l}0.074 \\
(0.18)\end{array}$ & $\begin{array}{l}0.052 \\
(0.15)\end{array}$ & $\begin{array}{l}-0.001 \\
(-0.00)\end{array}$ & $\begin{array}{l}0.197 \\
(0.41)\end{array}$ \\
\hline IND6 & $\begin{array}{c}1.058 * * \\
(2.54)\end{array}$ & $\begin{array}{l}-0.400 \\
(-1.52)\end{array}$ & $\begin{array}{l}0.236 \\
(0.67)\end{array}$ & $\begin{array}{l}-0.204 \\
(-0.72)\end{array}$ & $\begin{array}{l}0.034 \\
(0.08)\end{array}$ & $\begin{array}{l}0.163 \\
(0.40)\end{array}$ \\
\hline IND7 & $\begin{array}{c}0.133 \\
(0.34)\end{array}$ & $\begin{array}{l}0.174 \\
(0.64)\end{array}$ & $\begin{array}{l}0.018 \\
(0.05)\end{array}$ & $\begin{array}{l}0.259 \\
(0.89)\end{array}$ & $\begin{array}{l}-0.090 \\
(-0.22)\end{array}$ & $\begin{array}{l}-0.026 \\
(-0.07)\end{array}$ \\
\hline IND8 & $\begin{array}{c}0.948^{*} \\
(1.73)\end{array}$ & $\begin{array}{l}0.193 \\
(0.62)\end{array}$ & $\begin{array}{c}\text { 0.888* } \\
(1.88)\end{array}$ & $\begin{array}{c}0.596^{*} \\
(1.82)\end{array}$ & $\begin{array}{l}0.454 \\
(0.94)\end{array}$ & $\begin{array}{c}0.624 \\
(1.28)\end{array}$ \\
\hline $\mathrm{N}$ & 371 & 776 & 371 & 776 & 371 & 371 \\
\hline Pseudo $\mathrm{R}^{2}$ & 0.2463 & 0.0697 & 0.0357 & 0.0964 & 0.0881 & 0.1880 \\
\hline
\end{tabular}

\footnotetext{
${ }^{45}$ These results are based on all DAX30 and all MDAX50 (ISS, 2010, pp. 30-31).
} 
Notes (Panel A): The voting items are described as follows: dividend and profit allocation (M0152), discharge of the boards (M0260, M0261), nomination of new board members (M0228, M0250, M0275), auditor appointment (M0101), capital authorization (M0326, M0329, M0330, M0331, M0333, M0379), share repurchase programs (M0318, M0346, M0389), amendments of articles of association (M0106, M0122, M0126, M0227, M0377), remuneration proposals (M0219, M0550). For information and definitions on the individual Mgt. Rec. items, see Table $2-7$.

Notes (Panel B): Underlying probit regression model is:

Probit(ISSreport) $)_{\mathrm{iv}}=\alpha_{1}+\sum \alpha_{2}$ FIRM_CONTROL $_{\mathrm{iv}}+\varepsilon$

Depending on the underlying model (Model 1 to Model 6), ISSreport as the dependent variable indicates (with one and zero) the availability of specific ISS reports. In particular, for Model 1 and Model 2, ISSreport reflects the availability of all ISS reports in TRAA database (independently of whether corresponding voting results are available or not). For Model 3 and Model 4, ISSreport stands for the availability of ISS reports in the final sample (the availability in the final sample is substantially lower as voting results of the 2010 proxy season is not available for all initial sample firms, see Table 2 - 4). Finally, for Model 5 (Model 6), ISSreport reflects the availability of all ISS LF-reports (SF-reports) in the final sample. FIRM_CONTROL is a vector of firm characteristics which are likely to reflect any sample selection problems. Specifically, I consider SIZE (as log of total assets), BTM (as book to market ratio), ROA (as return on assets), HDAX (as index membership in HDAX), AF (as the number of analyst following), MEETING_JanJun (as indicating whether the shareholder meeting takes place in the first six month of the 2010 proxy season), and IND (as different SIC industry segments). For detailed descriptions of the variables, see Appendix 2 - 1. As indicated for each of the models, the underlying sample varies. Models 1, 3, 5, and 6 (Models 2 and 4) are based on all firms covered by ISS proxy advisory (all firms available in the German Worldscope universe) in 2010. The regression models have standard errors which are heteroskedasticity robust and one-way clustered at firm level. Reported values: coefficient $(\mathrm{t}$ value) $* * *(* *)(*)$ indicates a significance level at $1 \%(5 \%)(10 \%)$, two-tailed.

Consistent with the restricted availability of ISS reports in TRAA (reports are only available for firms with meetings between May and December), the dummy variable MEETING_JanJun becomes significant with a negative sign suggesting that the TRAA sample contains less ISS reports for meetings in the first six months of the proxy season 2010 (Model 1, Panel B of Table 2 - 11). In addition, SIZE and AF (analyst followings) become significant as well and indicate that the TRAA sample is selected by smaller firms. However, when examining the selection issue for the paper's final sample $(\mathrm{N}=185)$, the selection problem seems to disappear. As outlined in section 2.5.1, the paper's final sample is selected by the availability of 2010 voting results as well. Thus, it potentially selects - in the second step - larger firms with higher transparency and disclosure standards. As reflected in the results of Model 3 (Panel B, Table 2 - 11), the final sample does not differ statistically to the ISS firm universe (i.e., to the sample of firms which are covered by ISS during the 2010 proxy season) with respect to size, analyst followings, blue chip index membership, or even with respect to the time dependent distribution of shareholder meetings. Consequently, the paper's final sample appears to resemble the 2010 ISS firm universe fairly well. 


\section{Correlation vs. Causation}

As outlined in prior studies, a potential problem when analyzing the effects of proxy recommendations on voting outcomes is the distinction between correlation and causation (Choi et al., 2010, p. 878; Cai et al., 2009, p. 2404). Correlation rather than causation (i.e., endogeneity concerns) occurs if proxy advisors simply anticipate shareholders' voting behavior due to a similar underlying information set (e.g., firm-level information on performance or governance deficiencies). To address this problem in a first step, I include firm-fixed effects in the basic regression models and thus control for (observed / unobserved) firm characteristics, like poor financial performance or poor governance arrangements, which are likely to affect both the voting recommendations and the shareholder's voting behavior. To complement this, I perform two additional tests. First, I examine non-routine voting items. Second, I use voting recommendations issued by a German association of shareholders as a benchmark of publicly available information. Table 2 - 12 provides the corresponding results of both tests.

For most issues at AGMs, i.e., routine items (like the election of auditors), proxy recommendations are uncritical and follow internationally accepted best practice. In those instances, it is plausible to assume that proxy recommendations do not cause direct shifts in voting results but merely correlate with the latter (ESMA, 2012, p. 19). However, for some issues at AGMs, i.e., non-routine items (like votes on significant business decisions or remuneration packages), opinions about best practice might differ among shareholders and proxy advisors (ESMA, 2012, p. 19). This is also reflected in the circumstance that most advisory firms offer customized voting policies (ESMA, 2012, p. 13). IVOX, for example, states that "it is not unusual that IVOX provides five different recommendations for the same meeting." ${ }^{46}$ In addition, ISS $(2011$, p. 8$)$ outlines that almost $40 \%$ of its clients do not follow ISS general voting policy but receive voting recommendations based on customized voting policies. Thus, regression results based on non-routine items should mitigate to some extent the anticipation concerns stated above. Panel A of Table 2 - 12 supports my original findings. Although the average and the moderating effects are slightly smaller compared to the original findings provided in Table 2 - 9 (Models 1 to 4), the results are still economically meaningful (e.g., $7.71 \%$ vs. $8.5 \%$ less supportive votes in case of negative ISS recommendations). The results based on the LF-sample (Models 5 and 6) even reveal a similar economic significance compared to the original findings (13.69\% vs. $16.32 \%$ and $16.38 \%$ vs. $16.11 \%)$.

\footnotetext{
${ }^{46}$ IVOX response on ESMA 2012 discussion paper (http://www.esma.europa.eu/consultation/Consultation-DPOverview-Proxy-Advisory-Industry-Considerations-Possible-Policy-Options, last accessed June 30, 2014).
} 
Table 2 - 12: Regression Results: Correlation vs. Causation

Panel A. Prediction 1: Firm-Fixed-Effects Regressions: Non-Routine Voting Items

\begin{tabular}{|c|c|c|c|c|c|c|c|}
\hline & \multirow{3}{*}{$\begin{array}{l}\text { Pred. } \\
\text { Sign }\end{array}$} & \multicolumn{6}{|c|}{ Dependent Variable: VOTING RESULT (in \%) } \\
\hline & & \multicolumn{4}{|c|}{$\begin{array}{c}\text { Full Sample } \\
\text { (LF- and SF- ISS reports) }\end{array}$} & \multicolumn{2}{|c|}{$\begin{array}{c}\text { LF-Sample } \\
\text { (N with high Client Base) }\end{array}$} \\
\hline & & Model 1 & Model 2 & Model 3 & Model 4 & Model 5 & Model 6 \\
\hline & MODERATOR & - & CLIENT BASE & INVTURNOUT & FREE FLOAT & INVTURNOUT & FREE FLOAT \\
\hline Intercept & & $\begin{array}{c}97.374 * * * \\
(379.47)\end{array}$ & $\begin{array}{c}97.318^{* * *} \\
(415.31)\end{array}$ & $\begin{array}{c}96.289^{* * *} \\
(88.52)\end{array}$ & $\begin{array}{c}97.365^{* * *} \\
(318.17)\end{array}$ & $\begin{array}{c}95.965^{* * *} \\
(91.52)\end{array}$ & $\begin{array}{c}97.102 * * * \\
(254.81)\end{array}$ \\
\hline $\begin{array}{l}\text { ISS AGAINST } \\
\text { MODERATOR }\end{array}$ & - & $\begin{array}{c}-7.706^{* * *} \\
(-6.73)\end{array}$ & $\begin{array}{c}-2.958^{* * * *} \\
(-3.10)\end{array}$ & $\begin{array}{c}-4.996^{* * *} \\
(-6.71) \\
2.278 \\
(1.09)\end{array}$ & $\begin{array}{l}-4.786 * * * \\
(-5.76)\end{array}$ & $\begin{array}{c}-6.651^{* * *} \\
(-8.04) \\
2.764 \\
(1.19)\end{array}$ & $\begin{array}{l}-5.914 * * * \\
(-6.31)\end{array}$ \\
\hline ISS $\times$ MODERATOR & - & & $\begin{array}{c}-7.672 * * * \\
(-3.38) \\
\end{array}$ & $\begin{array}{c}-5.864 * * * \\
(-4.86)\end{array}$ & $\begin{array}{c}-6.325 * * * \\
(-3.34)\end{array}$ & $\begin{array}{c}-9.803 * * * \\
(-4.79)\end{array}$ & $\begin{array}{c}-10.463 * * * \\
(-3.48) \\
\end{array}$ \\
\hline $\begin{array}{l}\mathrm{N} \\
\text { Adj. } \mathrm{R}^{2}\end{array}$ & & $\begin{array}{c}660 \\
.5829\end{array}$ & $\begin{array}{c}660 \\
.6117 \\
\end{array}$ & $\begin{array}{c}660 \\
.5998 \\
\end{array}$ & $\begin{array}{c}660 \\
.6033 \\
\end{array}$ & $\begin{array}{c}382 \\
0.704 \\
\end{array}$ & $\begin{array}{c}382 \\
0.711 \\
\end{array}$ \\
\hline $\begin{array}{l}\text { Linear Prediction of } \\
\text { (a) ISS }=1 \& \text { Modera } \\
\text { (b) ISS }=1 \& \text { Modera }\end{array}$ & ing Result (in & & $\begin{array}{l}94.35 \\
86.68\end{array}$ & $\begin{array}{l}91.29 \\
87.70\end{array}$ & $\begin{array}{l}92.57 \\
86.25\end{array}$ & $\begin{array}{l}89.31 \\
82.27\end{array}$ & $\begin{array}{l}91.18 \\
80.72\end{array}$ \\
\hline
\end{tabular}

Panel B. Descriptive Analysis: SdK recommendations

\begin{tabular}{ll}
\hline SdK-ISS Sample: & SdK and ISS recommendations are available for $\mathbf{6 8 4}$ voting items \\
SdK rejection rate: & $\begin{array}{l}\text { SdK recommends to vote against items with a rejection rate of } \mathbf{2 2 . 8 1 \%}(156 \text { negative } \\
\text { recommendations out of } 684) \text {; the corresponding ISS rejection rate is } 12.13 \%(83 \\
\text { negative recommendations out of } 684)\end{array}$ \\
SdK-ISS overlap: & SdK and ISS issue negative recommendations in $\mathbf{4 2}$ cases simultaneously
\end{tabular}

Panel C. Prediction 1: Firm-Fixed-Effects Regressions: SdK Recommendations

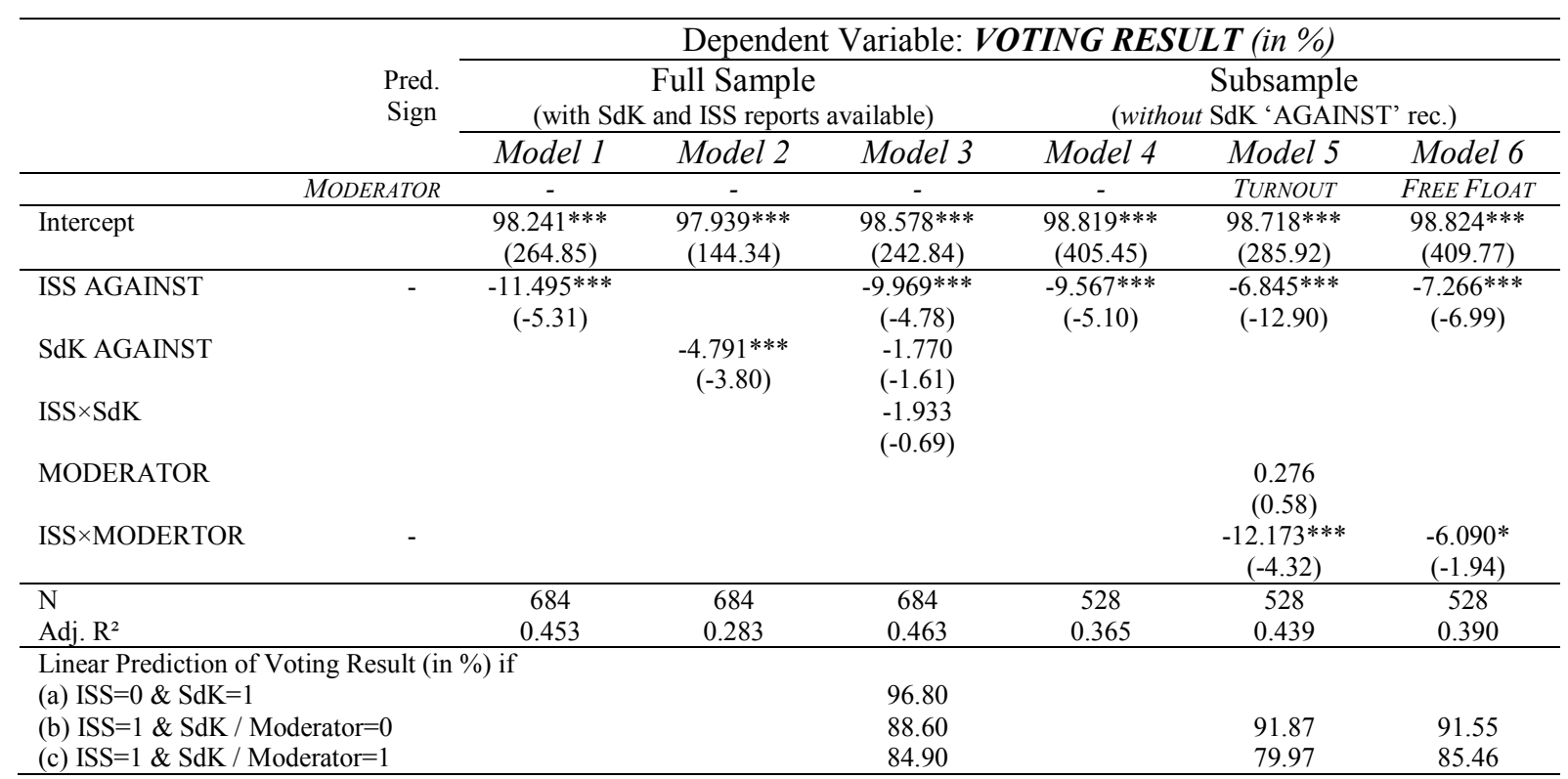

Notes: Underlying basic regression model is:

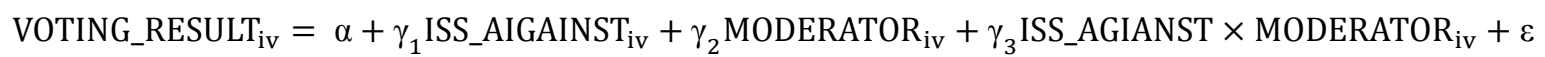

The dependent variable VOTING_RESULT ${ }_{\text {iv }}$ stands for the voting result (in \%) casted in favor of a specific voting item (management proposal) of firm i and AGM voting item v. ISS_AGAINST is a dummy variable indicating with 1 if ISS recommends to vote against a specific AGM voting item, and zero otherwise. MODERATOR stands for different dummy variables which are expected to moderate the relationship between ISS “vote against" recommendations and voting results, i.e., FREE FLOAT (with one if firm's free float is above average, and zero otherwise), and invTURNOUT (with one if firm's voting presence is below average, and zero otherwise), and CLIENT BASE (with one if firm is covered by ISS LF-report, and zero otherwise). The 
regression models have standard errors which are heteroskedasticity robust and one-way clustered at AGM voting item level. To control for (observed / unobserved) firm characteristics the regression models contain firmfixed effects. For detailed descriptions of the variables, see Appendix 2 - 1. Reported values: coefficient (t-value) $* * *(* *)(*)$ indicates a significance level at 1\%(5\%) $(10 \%)$, two-tailed.

To address the endogeneity issue from a different perspective, I use voting recommendations issued by the second largest German association of shareholders ( $\mathrm{SdK}$ ) as a benchmark of publicly available information. Again, the purpose is to control for 'a similar underlying information set' (like firm-level information on performance or governance deficiencies) which is likely to affect both the voting recommendations and the shareholder's voting behavior. SdK (Schutzgemeinschaft der Kapitalanleger e.V.) is a registered association and represents especially the interests of small and non-professional investors. Besides legal consultation and related legal services, SdK provides voting recommendations at no charge for a broad range of German AGMs (which are readily accessible on their website). Thus, SdK recommendations as benchmark information allow to identify a sample of voting items which are controversial from the shareholders' perspective (this is presumably the case if ISS and SdK differ in their voting recommendations). Thus, if ISS voting recommendations simply anticipate shareholders' voting behavior due to a similar underlying information set, they should not differ substantially from the recommendations issued by SdK. More importantly, if negative ISS recommendations only correlate with shareholder votes, they should have less impact on shareholder votes in situations which are controversial from the shareholders' perspective. This might especially be the case in situations where no consensus exists among the recommendations issued by ISS and SdK.

Based on a subsample of voting items for which both SdK and ISS recommendations are available ( $\mathrm{N}=684$ voting items), Panel $\mathrm{B}$ and Panel $\mathrm{C}$ of Table 2 - 12 provide the corresponding results. In particular, the descriptive results reveal substantial differences in the frequency of ISS and SdK to issue negative recommendations. SdK issues negative recommendations for $22.81 \%$ of all considered voting items in the sample, whereas ISS recommends the same for only $12.13 \%$. Most interesting, the final overlap of agreement, i.e., the agreement rate between SdK and ISS in situations where at least one of them issues a negative recommendation, only amounts to $21.3 \%{ }^{47}$ In addition, the subsequent regression results confirm my original findings (Panel C, Table 2 - 12). Specifically, the association

\footnotetext{
${ }^{47}$ In 114 (41) cases, SdK (ISS) recommends to vote against a specific voting item, whereas ISS (SdK) provides the opposite recommendations. Only in 42 out of 197 controversial cases (cases with negative recommendations from at least one of both advisors), SdK and ISS agree in their advisory decision.
} 
between ISS recommendations and shareholder votes is unaffected by the inclusion of SdK voting recommendations as an additional control variable (Model 3, Panel C, Table 2 - 12). Likewise, when considering a subsample of voting items which are controversial from the shareholders' perspective (Model 4 to Model 6, Panel C, Table 2 - 12), negative ISS recommendations correlate with shareholder votes on a similar level as documented in Table $2-9 .^{48}$ Overall, these findings suggest that ISS recommendations appear to affect voting outcomes beyond pure correlation.

\subsection{Conclusion}

Based on a German sample of 1,664 AGM voting items (185 individual firms) and the corresponding ISS voting recommendations for the proxy season 2010, my results suggest that proxy advisors potentially play an influential role at German AGMs. Specifically, negative ISS voting recommendations significantly correlate with $8.5 \%$ less supportive shareholder votes. This association is even more pronounced for firms with high free float (11.64\%), low voting turnout (11.59\%), and high ISS client base (11.21\%). However, ISS recommendations correlate with voting outcomes at a lower level compared to results documented in prior U.S. studies. In addition, my results contrast prior U.S. findings provided by Daines et al. (2010) and reveal significant correlations between two different ISS products, i.e., ISS proxy voting recommendations and ISS corporate governance ratings (GRId). Specifically, ISS's recommendations against the election of supervisory board members (against the remuneration system) are significantly correlated with ISS's evaluations of the corresponding board quality (of the remuneration system's quality). These findings highlight a potential method consistency with respect to ISS's employed governance perceptions.

Overall, this paper extends the growing but U.S. dominated literature on proxy voting advisory (e.g., Ertimur et al., 2013) and contributes to the current European debate on the regulation of proxy advisors. ESMA (2012, p. 33), for example, outlined that evidence on the influence of proxy advisors on voting outcomes is an important prerequisite before discussing potential market failures within the proxy advisory industry and evaluating potential policy options. Thus, the paper's findings might be relevant and informative for European regulators

\footnotetext{
${ }^{48}$ Based on the selected sample ( $\mathrm{N}=684$ with only LF-ISS reports), the results are comparable to the original ISS LF-results (Model 5 to 6, Table 2 - 9).
} 
as they provide first descriptive evidence on the influence and method consistency of proxy advisors for a major European market.

However, the findings are subject to several limitations. Most importantly, the paper's results do not allow for causal inferences. As outlined in prior studies, a potential problem when analyzing the effects of proxy voting recommendations on voting outcomes is the distinction between correlation and causation (Choi et al., 2010, p. 878; Cai et al., 2009, p. 2404). Correlation rather than causation occurs if proxy advisors simply anticipate shareholders' voting behavior due to a similar underlying information set. Although this paper employs a variety of tests (e.g., fixed-effect regressions or non-routine item regressions), it cannot ultimately rule out that the results are driven by a mere correlation between proxy recommendations and shareholder's voting behavior. In addition, this paper only analyzes the role and influence of one specific proxy advisor, namely ISS. Thus, future research may investigate, for example, the comparative differences in how proxy advisors correlate with voting outcomes at European shareholder meetings. Another path would be to challenge the robustness of my findings by conducting the analyses for alternative time frames and different European settings. Specifically, it is plausible to assume that institutional features, like the ownership structure in general, and the degree of foreign institutional holdings in particular, moderate the influence of proxy advisors across different jurisdictions. 


\subsection{Appendix}

Appendix 2 - 1: Definition of Variables

\begin{tabular}{|c|c|c|}
\hline SHORT CUT & VARIABLE & DEFINITION \\
\hline \multicolumn{3}{|c|}{ Panel A. Additional Firm-level Control Variables } \\
\hline SIZE & Log of total assets & $\begin{array}{l}\text { SIZE if the natural logarithm of total assets (EURO) } \\
(x w c 02999 e)\end{array}$ \\
\hline ROA & Return on assets & $\begin{array}{l}\text { ROA is calculated as net income available to common } \\
\text { shareholders }(w c 01751) \text { divided by total assets }(w c 02999)\end{array}$ \\
\hline BTM & $\begin{array}{l}\text { Book-to-market of } \\
\text { equity ratio }\end{array}$ & $\begin{array}{l}\text { BTM = common equity }(w c 03501) \text { deflated by market } \\
\text { capitalization }\left(w c 05001^{*} \text { nosh }\right)\end{array}$ \\
\hline HDAX & $\begin{array}{l}\text { Blue chip index } \\
\text { membership }\end{array}$ & $\begin{array}{l}\text { HDAX is a dummy variable indicating blue chip index } \\
\text { membership (i.e., HDAX: DAX30, MDAX50, TecDAX30) }\end{array}$ \\
\hline $\mathrm{AC}$ & Analyst coverage & $\begin{array}{l}\mathrm{AC} \text { is a dummy variable indicating the coverage by financial } \\
\text { analysts (based on flne) }\end{array}$ \\
\hline $\mathrm{AF}$ & Analyst following & AF is the number of analyst following (f1ne) \\
\hline
\end{tabular}

Panel B. Moderating Variables

\begin{tabular}{lll}
\hline CLIENT BASE & Client base of ISS & $\begin{array}{l}\text { CLIENT BASE is a dummy variable with one if the firm is } \\
\text { covered by ISS Long-Form reports, and zero otherwise (hand } \\
\text { collected and based on ISS reports provided by TRAA } \\
\text { database) } \\
\text { invTURNOUT is a dummy variable with one if the firm's } \\
\text { voting presence is below average, and zero otherwise } \\
\text { (individual voting turnout is hand collected) }\end{array}$ \\
FREE FLOAT* & $\begin{array}{l}\text { Foting turnout } / \\
\text { Fresence }\end{array}$ & $\begin{array}{l}\text { FRE FLOAT is a dummy variable with one if the firm's free } \\
\text { float is above average, and zero otherwise (free float is based on } \\
\text { wscope item noshf) }\end{array}$
\end{tabular}

Panel C. Main Interest Variables

\begin{tabular}{lll}
\hline ISS AGAINST & $\begin{array}{l}\text { ISS against } \\
\text { recommendations }\end{array}$ & $\begin{array}{l}\text { ISS AGAINST is a dummy variable indicating with one if ISS } \\
\text { recommends to vote against a specific AGM voting item, and } \\
\text { zero otherwise (ISS reports provided by TRAA database) }\end{array}$ \\
& $\begin{array}{l}\text { GRId is a corporate governance score provided by TRAA } \\
\text { GRId }\end{array}$ & $\begin{array}{l}\text { Gatabase (GRId subscores are provided by TRAA as well). } \\
\text { Indicator }\end{array}$ \\
& $\begin{array}{l}\text { GRId ranges (theoretically) between 0 and 12, whereas higher } \\
\text { GRId scores indicate better governance quality. }\end{array}$ \\
\hline
\end{tabular}

Panel D. Main Dependent Variable

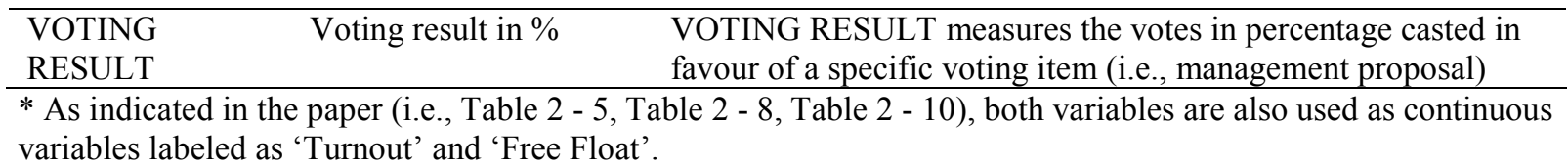




\section{Appendix 2 - 2: The German Business Press and ISS}

Panel A. Coverage of ISS in Handelsblatt / Wirtschaftswoche (1986 - 2013)

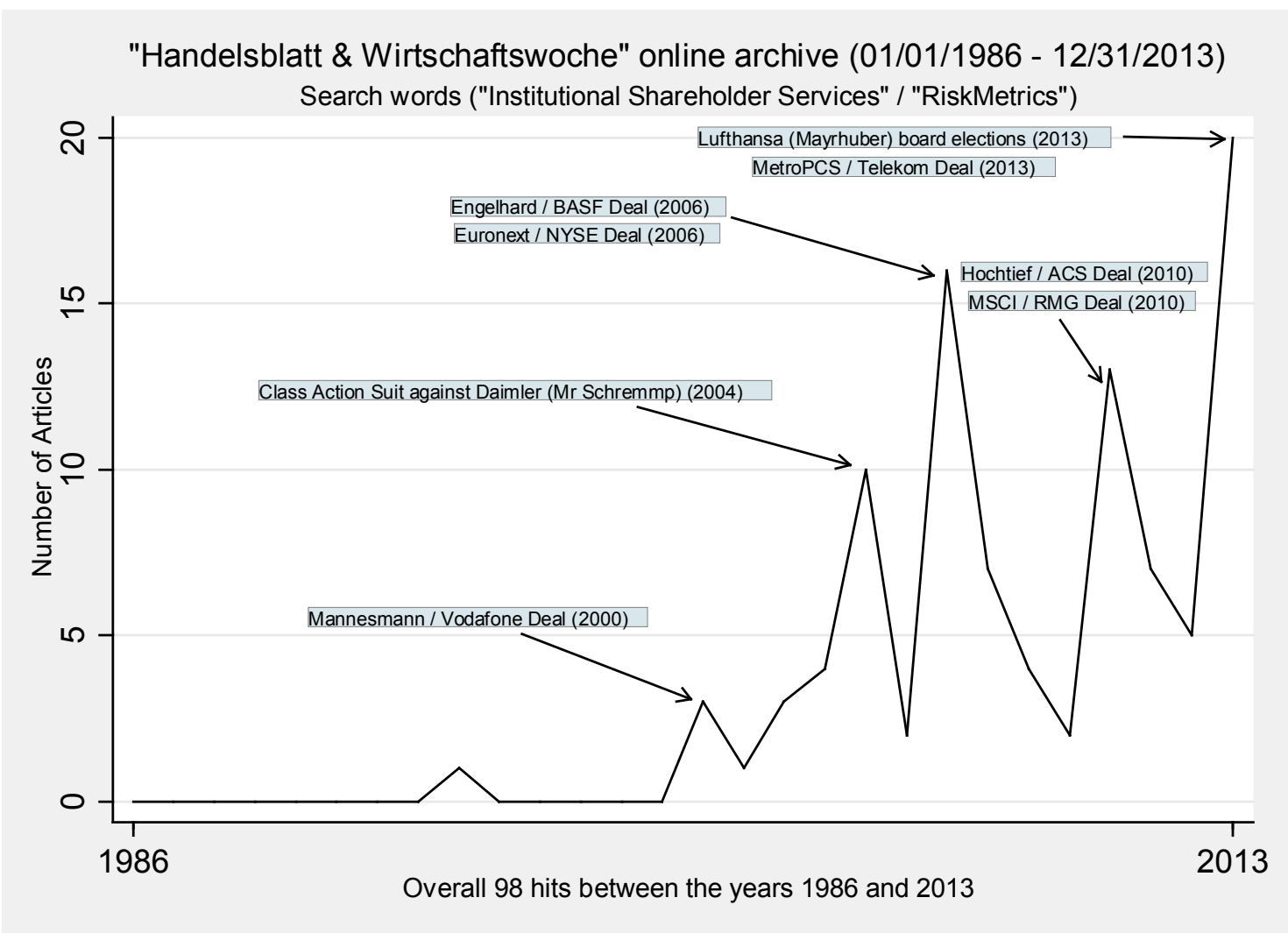

Panel B. Selected Synonyms of ISS in German Business Press

\begin{tabular}{|c|c|}
\hline $\begin{array}{l}\text { Manager Magazin, } \\
(19.07 .2013)\end{array}$ & $\begin{array}{l}\text { "Supernanny" (super nanny), "mächtiger Corporate-Governance-Wächter" (powerful } \\
\text { corporate governance guard), "die stille Macht" (the silent power) }\end{array}$ \\
\hline $\begin{array}{l}\text { Spiegel Online } \\
(07 / 05 / 2013)\end{array}$ & $\begin{array}{l}\text { "einflussreichste Schattenmacht der deutschen Konzerne" (the most influential 'state } \\
\text { within a state' among German firms) }\end{array}$ \\
\hline $\begin{array}{l}\text { Handelsblatt } \\
(06 / 05 / 2013)\end{array}$ & “einflussreiche Aktionärsberater” (influential shareholder adviser) \\
\hline $\begin{array}{l}\text { Handelsblatt } \\
(06 / 05 / 2013)\end{array}$ & $\begin{array}{l}\text { "Übernahmen, die Gehälter der Vorstände, die Besetzung von Aufsichtsratsposten- } \\
\text { wenn irgendwo auf der Welt bei einem Großkonzern eine wichtige Entscheidung } \\
\text { ansteht, hat oft auch eine Firma aus Washington ein wichtiges Wort mitzureden: Die } \\
\text { Aktionärsberater von Institutional Shareholder Services (ISS)."” }\end{array}$ \\
\hline $\begin{array}{l}\text { Wirtschaftswoche } \\
(25 / 01 / 2012)\end{array}$ & "Mächtige Aktionärsflüsterer” (powerful shareholder whisperer) \\
\hline $\begin{array}{l}\text { Wirtschaftswoche } \\
(25 / 01 / 2012)\end{array}$ & $\begin{array}{l}\text { „Viele Freunde hat Thomas von Oehsen nicht in den Top-Etagen der deutschen } \\
\text { Wirtschaft. Wo der Deutschland-Chef des US-Aktionärsberaters Institutional } \\
\text { Shareholder Services (ISS) auftaucht, gerät das Gebälk der Deutschland AG ins } \\
\text { Wanken-denn der unauffällige, 39-jährige Jurist kann Vorstandskarrieren bremsen, } \\
\text { Aufsichtsräte aus dem Amt kegeln und Kapitalerhöhungen blockieren. “ }\end{array}$ \\
\hline $\begin{array}{l}\text { Wirtschaftswoche } \\
(29 / 07 / 2010)\end{array}$ & "Rebellenführer auf Hauptversammlungen” (rebel leader on shareholder meetings) \\
\hline $\begin{array}{l}\text { Börsenzeitung Nr. } \\
\text { 49, S. } 8 \text { (10.03.2007) }\end{array}$ & "ISS einer neuer 'Guru”" (ISS as a new guru) \\
\hline $\begin{array}{l}\text { Die Welt, Heft } 121 . \\
\text { S. } 13(26 / 05 / 2006)\end{array}$ & “einflußreiche US-Aktionärsvertetung” (influential U.S. proxy advisor) \\
\hline
\end{tabular}




\title{
3. THE USEFULNESS OF CORPORATE GOVERNANCE RATINGS - INSIGHTS FROM EUROPEAN SETTINGS
}

\author{
Jörg-Markus Hitz and Nico Lehmann ${ }^{49}$
}

Working Paper ${ }^{50}$, Georg-August-Universität Göttingen

\begin{abstract}
This paper investigates the incremental usefulness of commercial corporate governance ratings to investors. For a European setting, we find a positive, significant association of ISS ratings with firm value. However, our measure of value generated through the rating process, i.e., ISS's rating technology, which includes weighting expertise and access to private information, does not turn out significant in the firm value regressions. As these findings prevail for two different governance systems, the UK and Germany, we rule out measurement error due to a 'one size fits all' governance rating approach. Our results are robust to several specification tests and suggest that the economic vindication of governance rating agencies may not stem from their expertise in converting public data into aggregated ratings.
\end{abstract}

JEL Classification: G24, G30

Keywords: corporate governance, commercial corporate governance ratings

Acknowledgments: For valuable comments, we are grateful to Igor Goncharov, Thorsten Sellhorn, Michael Stich (discussant), Walter Zucchini, participants at the Seminar in Applied Statistics and Econometrics, Goettingen University (December 2010), the Annual Meeting of the European Accounting Association in Ljubljana, Slovenia (May 2012), the WHU Accounting Research Seminar, WHU Otto Beisheim School of Management in Vallendar, Germany (May 2012), the Annual Meeting of the American Accounting Association in Anaheim, USA (August 2013), and two anonymous reviewers. We also thank Paul Wanner and Kristof Ho Tiu (both, ISS Governance Services, formerly RiskMetrics Group) for providing the CGQ data.

\footnotetext{
${ }^{49}$ Georg-August-Universität Göttingen, Faculty of Economic Sciences, Chair of Accounting and Auditing, Platz der Göttinger Sieben 3, 37073 Göttingen, Germany.

${ }_{50}$ The working paper is currently in a review process with European Financial Management ('revise \& resubmit' in August 2013). A current version of the working paper is also available at SSRN (http://papers.ssrn.com/sol3/papers.cfm?abstract_id=2042019, last accessed June 30, 2014). First version of the working paper: November 2011. This version: July 2014.
} 


\subsection{Introduction}

This paper sheds light on the usefulness of corporate governance (CG) ratings. CG ratings are marketed by professional CG rating agencies. These information intermediaries collect and process publicly available information, which they translate into governance ratings based on a proprietary weighting technology and their available information sets. Therefore, while the inputs to the rating process are publicly observable and made explicit by rating agencies, the transformation process (rating technology) represents an undisclosed source of individual competitive advantage. Given the increased popularity of commercial CG ratings, especially in the wake of corporate scandals like Enron, WorldCom, or Parmalat, the literature so far has been surprisingly silent on whether these ratings are valuable to investors. For instance, Ertugrul and Hegde (2009, p. 139) note that "there is little systematic study of the value of these third-party governance ratings in assessing firm value". Rather, prior studies in their majority investigate the association of commercial ratings and firm value, finding mixed evidence. Similarly, Daines et al. (2010) investigate the predictive ability of commercial governance ratings with respect to firm value and stock returns, accounting restatements, probability of litigation, and operating performance, finding only inconclusive or weak evidence of a positive role for governance rating vendors. Our study complements and augments prior work by directly addressing the economic vindication of commercial ratings and their vendors.

Our paper complements prior literature by directly shedding light on the incremental usefulness of commercial governance ratings. We investigate the potential value created by rating agencies in constructing their ratings (rating technology) and therefore directly address the claim of rating vendors that their ratings represent "a reliable tool for 1) identifying portfolio risk related to governance and 2) leveraging governance to drive increased shareholder value" (RiskMetrics Group, 2009, p.1). To that end, we exploit a unique dataset that includes both the observable input to the rating process, publicly available governance information, and the output of this process, the ratings. This enables us to isolate the incremental intermediation contribution of the governance rating agencies' rating technology, which we relate to firm value.

Using governance panel data provided by Institutional Shareholder Services (ISS) for its two major European markets, the United Kingdom (UK) and Germany, from 2003 to 2007, we perform two sets of tests. First, in line with prior literature, we relate the commercial CG 
rating to a measure of firm value, Tobin's Q. In a second step, we investigate the incremental usefulness of the commercial rating technology compared to the underlying publicly available governance data. To that end, we construct an equally weighted naïve rating based on the publicly available data that ISS reportedly uses in constructing its ratings. Because investors can access publicly available governance information without relying on the commercial rating vendor's services, we conjecture that the incremental value of ISS's proprietary technology is reflected in the incremental explanatory power of the commercial rating over the naïve rating. Therefore, we isolate the value generated by the firm's proprietary rating technology by regressing the commercial rating on the naïve rating. The residuals of this regression reflect our proxy variable for ISS's rating technology (TECHNOLOGY), which encompasses the rating firm's weighting methodology, and its access to private information. Assuming a positive economic role of the rating process, we conjecture that the coefficient estimate on TECHNOLOGY is positively associated with firm value. This is consistent with the commercial CG rating outperforming the naïve CG rating in terms of statistical and economic significance.

With respect to our first set of analyses, our results document a significantly positive relationship between the commercial CG rating and firm value. However, in our second set of analysis, our variable that captures the incremental contribution of the rating technology (TECHNOLOGY), does not turn out significant in the firm value regressions. Consistent with this, the commercial CGQ rating is not able to outperform our naïve equally-weighted rating in terms of statistical as well as economic significance. These results suggest that the rating agency's processing and information enhancement activities do not result in more accurate assessments of governance quality. We then exploit the institutional diversity of the two European jurisdictions in our analyses, the UK and Germany. While the UK is conventionally regarded as a common-law country with a shareholder model of corporate governance, which is similar to the U.S. and focuses on resolving shareholder-manager conflicts (Bebchuk and Hamadani, 2009), Germany represents a code-law country with a stakeholder model of corporate governance geared at resolving conflicts between majority and minority shareholders. We repeat our initial analyses separately for both jurisdictions, and are able to confirm our initial findings for both the UK and Germany. This demonstrates that the failure of professional ratings to incrementally explain firm value persists over different governance environments. Accordingly, we are able to rule out that our results are due to the rating vendor applying a ‘one-size-fits-all approach' of US (UK) governance standards. 
This paper contributes to the extant literature by shedding light on the incremental usefulness of professional CG ratings and, ultimately, the economic role of governance rating firms. Our findings have at least two implications. First, we confirm the findings of Renders et al. (2010) by providing positive rating-valuation results for two major European capital markets. More importantly, while governance quality appears to matter in terms of firm value, we do not find support for the notion that the data processing and refining activities performed by one major governance rating vendor, ISS, provide incremental value, neither in a continental European setting, nor in the UK. This finding raises questions as to the economic vindication of rating vendors' intermediation activities.

The findings of this paper are important for investors and corporate managers as they suggest that high governance ratings to some extent may indicate higher corporate valuation. However, findings also suggest that the competitive edge of rating agencies may not lie in their information processing and enhancement activities, but rather in the services they provide via cost-efficient collection of publicly available governance data, and other activities. On a more general level, our findings are important for policy makers and corporate managers who implement and rely on national governance codes with 'comply-or-explain' principles, as results suggest that companies can improve their performance by complying with codes of good corporate governance.

The remainder of the paper is organized as follows: Section 3.2 provides background information on commercial CG ratings and reviews the related empirical literature. Sections 3.3 and 3.4 develop our empirical predictions and outline the model structure. Section 3.5 presents the results and discusses the implications of our findings. Section 3.6 concludes.

\subsection{Background and Related Literature}

\subsubsection{Commercial Corporate Governance Ratings}

Governance business has been vastly growing throughout the last decade, and commercial governance ratings have become increasingly popular and influential among investors and regulators (Ertugrul and Hegde, 2009; Epps and Cereola, 2008). Rose (2007, p. 887) notes for the U.S. market that "the corporate governance industry influences [...] the votes of trillions of dollars of equity, and affects the governance policies and fortunes of thousands of companies through proxy voting recommendations and governance ratings." Four firms 
dominate the U.S. market, Governance Metrics International (GMI), Institutional Shareholder Services (ISS), The Corporate Library (TCL), and Standard \& Poor's (S\&P) (Koehn and Ueng, 2007). ${ }^{51}$ Their business consists of (unsolicited) assessments of firms' governance quality, proxy advisory to investors, i.e, recommendations on how to vote on annual general meetings, consulting companies how to improve their governance systems, and acting as think tanks especially in U.S. public discussions (Daines et al., 2010). Although still small in comparison, the governance business is growing in Europe as well. ISS, for example, acquired the Belgium firm Deminor Rating (a subsidiary of Deminor, which offers CG ratings) in 2005. Also, new market players evolve, such as IVOX in Germany (IVOX, 2012).

The "most visible governance rating" (Daines et al., 2010, p. 440) is ISS's CGQ, which was introduced in 2002 and, using underlying data points for up to 67 individual corporate governance variables, covers more than 8,000 companies across 31 countries (RiskMetrics, 2007). In 2010, ISS revised its governance rating and launched a new Governance Risk Indicator (GRId), which is not materially different to the CGQ rating (Larcker and Tayan, 2011). Similar ratings are marketed by the other four rating vendors, with differences in taxonomy and scope. ${ }^{52}$

From an economic point of view, proxy advisory and governance rating firms represent information intermediaries, i.e., institutions that "reduce transaction costs in the capital market by providing specialized services and gathering and disseminating information" (Healy and Palepu, 2002, p. 4). Rating firms collect publicly available information, process and enhance this information, and disseminate it to capital market participants. To the extent that this process creates more accurate or less expensive assessments of governance quality, it

\footnotetext{
${ }^{51}$ ISS (as a subdivision of MSCI, and formerly of RiskMetrics Group) represents the dominant firm in the governance market (Rose, 2007). The majority of ISS turnover (around 65\%) is generated in the proxy advisory business. ISS reportedly provides proxy services for over 1,700 institutional investors managing \$26 trillion in assets, including 24 of the top 25 mutual funds, 25 of the top 25 assets managers, and 17 of the top 25 public pension funds (Belinfanti, 2009, p. 397 ff). ISS's governance rating (GRId / CGQ) is available for institutional investors and corporations through a larger subscription package (Coffin and Collinson, 2005). Prior literature raises concerns with the vendors' independence and their conflict of interests in assessing governance quality and providing proxy voting advisory (e.g., Koeng and Ueng, 2007, p. 61; Rose, 2007, pp. 891, 906; Vo, 2008 , p. 17).

${ }^{52}$ Since 2000, S\&P has been assessing firms' corporate governance quality. Its former governance rating provided a score with a range from one to ten, including four overall governance categories. In 2007, S\&P revised its governance rating and launched the Standard \& Poor's Governance, Accountability, Management Metrics \& Analysis' (GAMMA) score, which also picks up - besides governance issues - risk and strategy issues (S\&P, 2008). The GMI governance rating with a scoring scheme from one to ten covers almost 3,400 U.S. and international companies, and uses 600 underlying governance provisions based on seven categories (Derwall and Verwijmeren, 2007). The TCL rating covers over 2,000 U.S. companies and provides letter scoring ranging from A to F by using 120 variables based on six categories. In 2010, GMI and TCL announced their merger, and have since combined their products and services (Marketwire, 2010).
} 
is potentially valuable to investors in economic terms.

Figure 3 - 1: Rating Process of Commercial CG Ratings

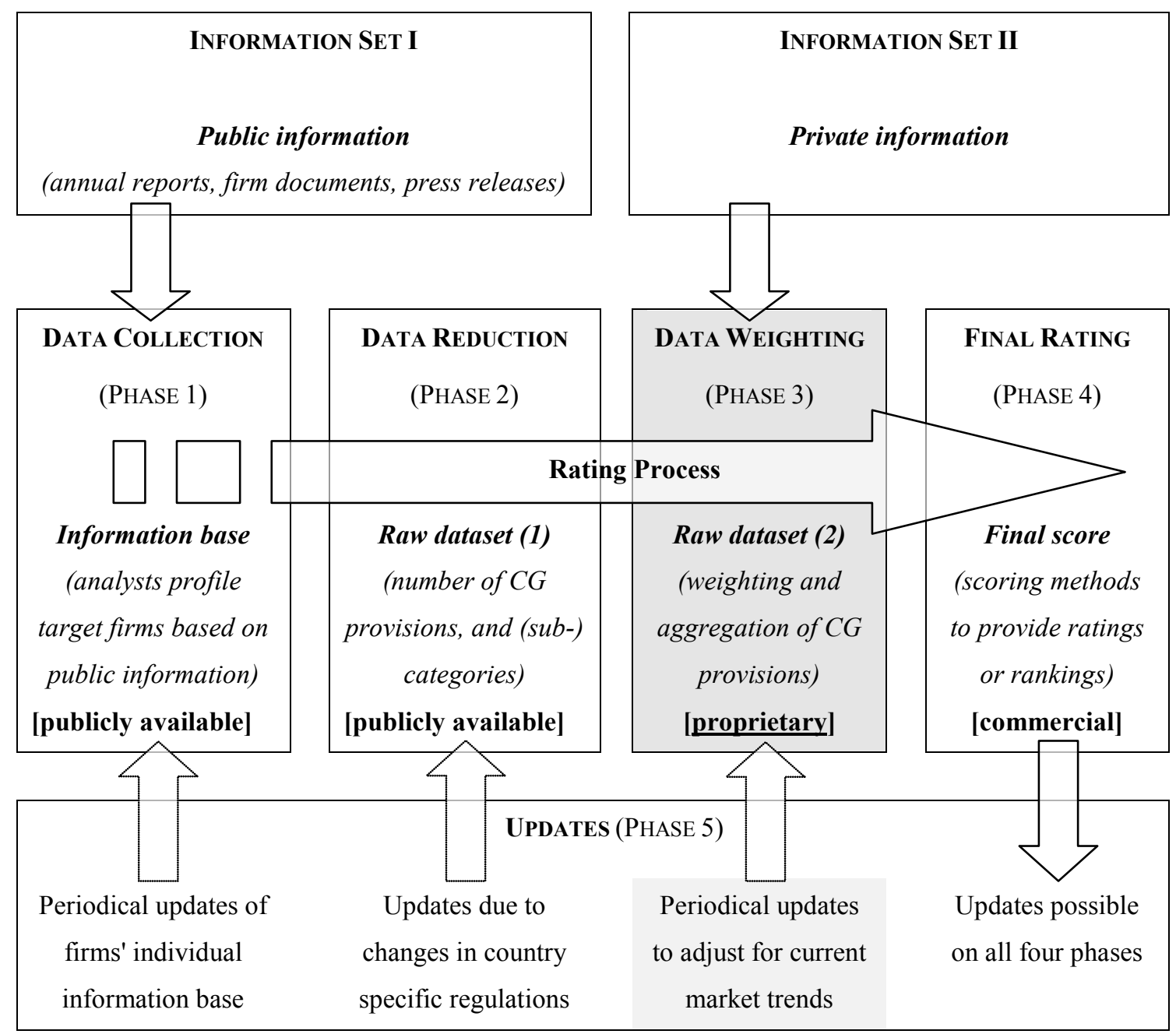

Figure 3 - 1 visualizes the process of commercial $\mathrm{CG}$ ratings. We distinguish five phases, which are associated with different sources of potential value generation. In phases one and two, respectively, governance rating vendors collect and aggregate publicly available data. These services are potentially valuable as they spare transaction costs on the investor level, creating cost savings. In phase three, the data is processed and translated into ratings. This process is based on the rating agency's proprietary technology and draws from two sources, which both potentially constitute competitive advantages. For one thing, the rating firm uses a unique method to process and weigh governance information. ISS, for example, reportedly runs more than 4,000 statistical tests based on 16 variables of firm valuation / 
performance and risk to assess the optimal weighting of the underlying governance criteria used in these analyses (Daines et al., 2010). Also, the rating methodology and weighting are adjusted periodically to capture current market trends (RiskMetrics, 2007). If this technology is superior or more accurate compared to investors' assessments, it provides potentially valuable ratings. Second, in addition to processing publicly available information, rating firms may in this phase also factor into their ratings private information, which they gather, e.g., from informal ties and communication with the firms. Because only the output of the process, the rating, is observable (phase four), any incrementally valuable information contained therein may be attributed to the rating firm's superior weighting technology, its private information, or both. Phase five involves regular updates of the rating, which pertain to all four prior phases. Throughout this whole process, rating agencies need to trade off protection of their proprietary technology or superior information sources against disclosing their processes and techniques to convey their expertise to market participants (Balling et al., 2005).

In this paper, we investigate in detail the incremental value generated by the rating agency's proprietary rating technology, to glean insights into the sources of competitive advantage and the potential information value of commercial governance ratings.

\subsubsection{Related Literature}

Our paper speaks to two related streams of literature, the governance-performance and the governance rating literature. With respect to the former, early results for the U.S. market support the general notion that corporate governance is positively related to firm value (e.g., Gompers et al., 2003). Comparative corporate governance studies extend these results to cross-country settings, indicating that country-level institutional arrangements are related to corporate valuation (e.g., Klapper and Love, 2004). Various other studies examine the relation between specific governance features and firm performance, obtaining mixed results (e.g., Dalton et al., 2003 for shareholder structure; Kang and Stulz, 2000 for capital structure; De Andres et al., 2005 for boards; Core and Larcker, 2002 for incentive systems; Burkart and Panunzi, 2006 for the market for corporate control). More recent studies find no consistent evidence of a positive relation between governance quality and firm performance, which the authors attribute to biases in prior papers owing to time-specific irregularity, absence of learning effects, endogeneity, or specification errors in the model structure (e.g., Lehn et al., 
2006; Bebchuk et al., 2013; Gow et al., 2010).

The second literature stream, papers on governance ratings, responds to the growing importance of CG rating services and proxy voting advisory. These papers address issues like the growth and influence of rating vendors (Rose, 2007; Vo, 2008), the necessity of governance rating and consulting services (Koehn and Ueng, 2007), the role and regulation of proxy advisors (Larcker et al., 2011), or the methodology of the rating process (Balling et al., 2005). Table 3 - 1 provides an overview of those papers that directly address the question whether commercial CG ratings are indicative of firm-level governance quality. While two earlier U.S. studies present evidence in favor of commercial ratings using governance measures based on the vendor's underlying database (Brown and Caylor, 2006/2009), recent U.S. and European papers directly investigate the rating scores, finding mixed evidence. For instance, Epps and Cereola (2008), using ISS ratings, do not reveal significant associations with operating firm performance for U.S. firms. In comparative studies, Daines et al. (2010) and Ertugrul and Hegde (2009) examine three ratings for the U.S. market, ISS, GMI, and TCL, and find that these summary scores have either a limited or no success at all in predicting firm performance / valuation. Bauer et al. (2004) find for a sample of European firms that high Deminor ratings are not associated with high firm performance, but are negatively correlated with operating performance.

In contrast, Derwall and Verwijmeren (2007) and Spellman and Watson (2009) find significant evidence that GMI ratings for U.S. firms are valuable for investors by indicating among others lower implied cost of equity capital as well as higher shareholder and accounting returns. Vander Bauwhede (2009) relates a subset of the Deminor rating, criteria regarding the board structure, to operating firm performance, establishing an overall positive and significant relationship for a European sample. Renders et al. (2010) find that, after controlling for sample selection and endogeneity, Deminor ratings of European firms are positively and significantly associated with various proxies for firm performance (Tobin's Q, return on equity, and return on assets). The authors maintain that the lack of consistent results of prior studies is due to the absence of simultaneous control for sample selection and endogeneity.

Taken together, research on the relation between governance quality, governance ratings, and firm performance is plentiful, yet still at a rather early stage, with little robust evidence. This owes to the complex relation between governance and firm performance, but 
also to methodological issues. Also, it remains an open empirical question whether and how governance rating agencies provide value to their customers and therefore play an economically meaningful role. We shed light on this very issue by investigating the incremental value of the information processing and enhancing activities of corporate governance rating vendors.

Table 3 - 1: Prior Literature on Corporate Governance Ratings and Firm Value

\begin{tabular}{|c|c|c|c|}
\hline Authors & Period [Sample] & Rating Type & Main Findings \\
\hline Brown \& Caylor (2006) & 2002 [U.S.] & Adj. ISS & $\begin{array}{l}\text { Positive association between CG rating } \\
\text { and firm value }\end{array}$ \\
\hline Brown \& Caylor (2009) & 2002 [U.S.] & Adj. ISS & $\begin{array}{l}\text { Positive association between CG rating } \\
\text { and firm operating performance }\end{array}$ \\
\hline Epps \& Cereola (2008) & '02-’04 [U.S.] & ISS & $\begin{array}{l}\text { No sign. association between } \mathrm{CG} \text { ratings } \\
\text { and firm operating performance }\end{array}$ \\
\hline Daines et al. (2010) & 2005 [U.S.] & ISS/GMI/TCL & $\begin{array}{l}\text { No sign. association between CG ratings } \\
\text { and future firm performance / value }\end{array}$ \\
\hline Ertugrul \& Hedge (2009) & ‘03-’06 [U.S.] & ISS/GMI/TCL & $\begin{array}{l}\text { No sign. association between CG ratings } \\
\text { and firm performance }\end{array}$ \\
\hline Bauer et al. (2004) & ‘98-’02 [EU] & Deminor & $\begin{array}{l}\text { No sign. association between CG ratings } \\
\text { and future firm performance }\end{array}$ \\
\hline $\begin{array}{l}\text { Derwall \& Verwijmeren } \\
\text { (2007) }\end{array}$ & ‘03-’05 [U.S.] & GMI & $\begin{array}{l}\text { Negative association between CG rating } \\
\text { and implied cost of equity capital }\end{array}$ \\
\hline Spellman \& Watson (2009) & ‘03-’08 [U.S.] & GMI & $\begin{array}{l}\text { Positive association between CG rating } \\
\text { and shareholder / accounting returns }\end{array}$ \\
\hline Vander Bauwhede (2009) & ‘01-’02 [EU] & Deminor & $\begin{array}{l}\text { Positive association between CG rating } \\
\text { and firm operating performance }\end{array}$ \\
\hline Renders et al. (2010) & '99-’03 [EU] & Deminor & $\begin{array}{l}\text { Positive association between CG rating } \\
\text { and firm value / operating performance }\end{array}$ \\
\hline \multicolumn{4}{|c|}{$\begin{array}{l}\text { Notes: The table summarizes } 10 \text { corporate governance studies which examine the performance impact of } \\
\text { commercial corporate governance ratings. Rating types include ISS (Institutional Shareholder Services) rating; } \\
\text { Adj. ISS (auxiliary rating based on the ISS single provisions); GMI (Governance Metrics International) rating; } \\
\text { TCL (The Corporate Library) rating; Deminor rating. }\end{array}$} \\
\hline
\end{tabular}

\subsection{Empirical Predictions}

\section{Corporate governance quality and firm value}

Our first prediction pertains to the relation between the quality of corporate governance, measured by the commercial CG rating, and firm value. A comprehensive theoretical and empirical literature, starting with Jensen and Meckling (1976), shows that the quality of a firm's internal and external governance mechanisms is positively related to firm value. Accordingly, Drobetz (2002, p. 432) observes that "good corporate governance reduces the agency costs brought about by the separation of ownership and control, e.g., it allows investors to spend less time and resources on monitoring management teams". If rating agencies are successful in collecting and aggregating information which is indicative of governance quality, we expect their ratings to show a positive association with firm value. 


\section{Incremental value of corporate governance ratings}

As laid out in section 3.2.1, the existence of rating agencies and their ability to market commercial corporate governance ratings receives economic vindication if they create and sustain competitive advantage (1) by collecting information, and / or (2) by processing and refining this information, and / or (3) by accessing non-public information. The first source of competitive advantage creates savings of transaction costs for investors, who delegate costly collection of publicly available information about governance characteristics. The second source of competitive advantage is reflected by the agency's technology for aggregating and weighting the information collected. Finally, the third source stems from superior informational channels and access to sources of private information.

As noted, the weighting activities and the use of private information cannot be directly observed because the process of generating ratings is proprietary. However, as we have access to both the input to the rating process, the set of publicly available data the rating vendor uses, and to the output of the process, the governance ratings, we are able to isolate the rating vendors technology, which combines its aggregation skills and/or the potential access to and use of private information. If rating agencies create value by performing these activities, we expect their ratings to have explanatory power for firm value incremental to the underlying raw dataset of governance data, which is taken from public sources. Therefore, our second prediction is that the commercial corporate governance ratings vendor's proprietary rating technology is incrementally positively associated with firm value, relative to the underlying publicly available data.

\section{Role of the underlying governance model}

As noted, the major governance rating firms are domiciled in the U.S. Therefore, despite adjustments performed in developing ratings for non-U.S. firms, commercial rating firms are likely to adopt a U.S. perspective on the factors that shape governance quality. ${ }^{53}$ For example, Bebchuk and Hamdani (2009) conduct a detailed analysis of the factors that ISS analyses and find that these are consistent with the U.S. model of dispersed ownership, while they do not fit well to firms with controlling shareholders, where the principal issue is to protect minority shareholder from expropriation by the controlling parties. On a broader level, U.S. domiciled

\footnotetext{
${ }^{53}$ For example, the majority of firms covered by ISS are U.S. domiciled (5,200 U.S firms compared to 2,800 international firms) (e.g., Koehn and Ueng, 2005).
} 
rating vendors are likely to adopt a shareholder perspective of corporate governance, while in many jurisdictions, especially in continental Europe, governance issues relate to resolving conflicts and balancing demands from diverse stakeholders, including investors, creditors, and employees. Therefore, as a third prediction, we expect the incremental value of governance ratings to be sensitive to this institutional setting, and to turn out lower for settings that are substantially different from the U.S. In particular, we expect the incremental association between rating technology and firm value (prediction 2) to be lower in statistical terms for firms domiciled in a continental European, stakeholder oriented setting, compared to firms from a U.S. style shareholder environment.

We address or third prediction by conducting our analyses for two institutional backgrounds, one with a shareholder value based model aimed at resolving problems in firms with dispersed ownership, and one with a stakeholder model with an emphasis on protecting minority shareholders. We use the UK and Germany, respectively, to proxy for these environments. The Anglo-Saxon UK and U.S. settings have many market and institutional features in common, whereas they differ in various aspects to continental European environments such as Germany, e.g., with respect to the legal tradition, firms' access to external financing, or the importance of organized capital markets. ${ }^{54}$ In particular, AngloSaxon and continental European countries differ in the legal and factual governance mechanisms in place, and with respect to the prevailing perception of what governance mechanisms ought to achieve and what constitutes good governance. These differences are conventionally subsumed under the dichotomy of shareholder-oriented and stakeholderoriented governance perspectives. Goergen et al. (2008, pp. 37), for example, contrast the German governance system to the Anglo-Saxon system "by the important role that large shareholders and banks play, a two-tier board structure with labor participation on the supervisory board of large companies, the absence of hostile takeovers", and the explicit focus on "stakeholder value maximization", which is also reflected in the mandate for managers to promote the interest of the firm rather than shareholders' interest (Baums and Scott, 2005).

\footnotetext{
${ }^{54}$ A large body of research examines the differences in institutional settings and capital markets. In their seminal paper, La Porta et al. (1998, p. 1113), for example, find evidence that "common-law countries [like the U.S. or the UK] have the strongest, and French-civil-law countries the weakest, legal protection of investors, with German- and Scandinavian-civil-law countries located in the middle".
} 


\subsection{Research Design}

\subsubsection{Basic Regression Models}

We address our first prediction using the following regression model:

$V A L_{i t}=\alpha+\beta C G Q_{i t}+\sum_{q=1}^{Q} \gamma_{q} \operatorname{CONTROL}_{q i t}+\sum_{r=1}^{R} \delta_{r} Y E A R_{r i t}+\sum_{s=1}^{S} \varphi_{S} I N D U S T R Y_{s i t}+\varepsilon$

The dependent variable $V A L$ reflects firm value, which we measure in line with prior finance and governance studies by using Tobin's Q (e.g., Bebchuk et al., 2009). CGQ is our main test variable, the value of the commercial corporate governance rating. In line with our first prediction, we expect that the coefficient $\beta$ obtains a positive sign. CONTROL represents a vector of variables that capture firm characteristics which prior literature has demonstrated to affect firm value, including size, leverage, growth, free float, capital-intensity, and index membership (e.g., Gompers et al., 2003; Drobetz et al., 2004; Beiner et al., 2006; Brown and Caylor, 2006; Aggarwal et al., 2009; Bebchuk et al., 2009; Renders et al., 2010). We also control for year- and industry-fixed effects (e.g., Bebchuk et al., 2009; Bauer et al., 2004; Renders et al., 2010). To address time-series dependence in our panel dataset, we use standard errors which are heteroskedasticity robust (White, 1980) and one-way clustered ${ }^{55}$ at the firm level (Gow et al., 2010; Petersen, 2009). In our robustness tests, we conduct several specification tests.

We address our second prediction using the following regression model:

$$
\begin{gathered}
V A L_{i t}=\alpha+\beta_{1} \text { CGI }_{i t}+\beta_{2} \text { TECHNOLOGY }_{i t}+\sum_{q=1}^{Q} \gamma_{q} \text { CONTROL }_{q i t}+\sum_{r=1}^{R} \delta_{r} \text { YEAR }_{r i t} \\
+\sum_{s=1}^{S} \varphi_{s} \text { INDUSTRY }_{\text {sit }}+\varepsilon
\end{gathered}
$$

The dependent variable $V A L$, the vector of control variables CONTROL, and the year and industry fixed effects are defined as for model (1). Again, we use standard errors which are heteroskedasticity robust and one-way clustered at the firm level. $C G I$ and TECHNOLOGY are the main test variables. CGI is a naïve, self-constructed governance rating based on the CGQ raw dataset. TECHNOLOGY captures the incremental portion of the CGQ

\footnotetext{
${ }^{55}$ Newey-West, Fama-MacBeth, and one-way clustered standard errors are common approaches in the literature. Following Gow et al. (2010), two-way clustered standard errors achieve on average more robust inferences than the other three methods. However, in cases where the sample contains many firm but only few time observations, two-way- and one-way- clustered standard errors are similarly efficient.
} 
rating that is generated by the rating agencies' technology, i.e. its weighting technology and the use of non-public information. In line with our second prediction, we assume that the coefficient $\beta_{2}$ obtains a positive sign. Consistent with this, we expect that the coefficient estimate of the commercial rating ( $\beta$ of model 1 ) yields higher statistical and economic significance levels than the coefficient estimate of our naïve CG rating ( $\beta_{1}$ of model 2 ).

Our third prediction that institutional factors or country of origin matters for the incremental value of the TECHNOLOGY variable is addressed by sampling UK and German firms, and then conducting our statistical tests (i) for the UK and (ii) the German sample separately, as well as (iii) for a joint sample with interaction terms between our governance variables and a UK indicator variable. As noted, we expect to observe higher statistical and economic significance levels of our governance variables in the UK sample compared to the German sample. For the joint sample, we expect positive and significant coefficient estimates on our interaction terms. These expectations, however, are conditional on the empirical content of our prior predictions one and two.

\subsubsection{Corporate Governance Variables}

We use all available ISS CGQ 'Country Ranking' scores for the UK and Germany from 2003 through 2007 as our measure of the commercial CG rating (CGQ). As a relative measure, the CGQ variable indicates the governance quality of firms relative to other firms in their industry, in their index, or in their country. For example, a company's 'Country Ranking' of 69.5 expresses that the company's total governance quality score was higher than $69.5 \%$ of the scores of all other rated companies in that country (RiskMetrics Group, 2007).

To construct our naïve corporate governance (CGI) rating, we use the underlying raw dataset of the CGQ rating provided by ISS and the latest 'Corporate Governance Quotient Indicator definition' published by ISS in 2007 (RiskMetrics Group, 2007). ISS states that CGQ ratings for non-US companies are based on a maximum of 55 rating criteria. However, because some of those criteria are not applicable under the respective national law, the CGQ rating for UK and German firms is based on only 47 and 41 criteria, respectively. These rating criteria fall into eight categories: board issues, audit, charter \& bylaws, anti-takeover, executive and director compensation, progressive practice, stock ownership, and education. For each criterion, compliance is established (and the variable takes a value of one) if the firm's governance standards are minimally acceptable according to the benchmark laid down 
in ISS's 'Corporate Governance Indicator definition'.

Table 3 - 2: CGQ Rating Criteria, ISS Dimensions, and Compliance

Panel A. CGQ Provisions and corresponding Compliance Rates: UK [GER]

\begin{tabular}{|c|c|c|c|c|c|c|c|}
\hline No & Minimum governance standard & ISS dimension & 2003 & 2004 & 2005 & 2006 & 2007 \\
\hline 1 & Board composition: $66.67 \%$ [50\%] independent & Board (1) & $5[0]$ & $5[2]$ & $5[45]$ & $6[65]$ & $7[70]$ \\
\hline 2 & Nominating committee: $100 \%$ independent & Board (2) & $17[0]$ & $26[0]$ & $25[1]$ & $23[2]$ & $27[4]$ \\
\hline 3 & Compensation committee: $100 \%$ independent & Board (3) & $58[0]$ & $70[0]$ & $68[3]$ & $70[2]$ & $71[2]$ \\
\hline 4 & Board structure: not classified & Board (4) & $3[0]$ & $3[1]$ & $7[0]$ & $77[0]$ & $12[5]$ \\
\hline 5 & Governance committee in place & Board (5) & $1[1]$ & $1[16]$ & $3[15]$ & $2[23]$ & $2[13]$ \\
\hline 6 & Board attendance of all directors: $>=75 \%$ & Board (6) & $9[1]$ & $50[1]$ & $73[11]$ & $85[19]$ & $93[14]$ \\
\hline 7 & Governance guidelines are publicly disclosed & Board (7) & $99[2]$ & $70[6]$ & $63[66]$ & $95[71]$ & 99 [87] \\
\hline 8 & Boards by directors other than $\mathrm{CEO}<=5$ & Board (8) & $10[3]$ & $21[95]$ & $16[100]$ & $17[100]$ & $2[100]$ \\
\hline 9 & CEO served on boards of public companies: $<=2$ & Board (9) & $96[46]$ & $98[49]$ & $96[56]$ & $90[77]$ & $98[78]$ \\
\hline 10 & No related-party transaction of the CEO & Board (10) & $97[71]$ & $96[30]$ & $93[85]$ & 87 [93] & $94[89]$ \\
\hline 11 & Board size is $>=9[6]$ and $<=15$ & Board (11) & $50[90]$ & $51[89]$ & $40[85]$ & $40[83]$ & $37[86]$ \\
\hline 12 & No former CEO on the board & Board (12) & 80 [92] & $80[49]$ & $87[68]$ & $88[70]$ & $87[66]$ \\
\hline 13 & Chairman \& CEO separated / lead director & Board (13) & $97[-]$ & $99[-]$ & $97[-]$ & $98[-]$ & $97[-]$ \\
\hline 14 & Right to vote on changes on board size & Board (15) & $5[-]$ & $0[-]$ & $0[-]$ & $1[-]$ & $1[-]$ \\
\hline 15 & Response to shareholder proposal & Board (17) & $100[-]$ & $100[-]$ & $100[-]$ & $100[-]$ & $100[-]$ \\
\hline 16 & Audit committee: $100 \%$ independent & Audit (1) & $55[0]$ & $70[0]$ & $68[4]$ & $70[4]$ & $75[2]$ \\
\hline 17 & Policy disclosed regarding auditor rotation & Audit (2) & $0[4]$ & $0[0]$ & $18[100]$ & $16[100]$ & $24[98]$ \\
\hline 18 & Consulting fees are less than audit fees & Audit (3) & $1[82]$ & $0[80]$ & $61[25]$ & $63[87]$ & $62[95]$ \\
\hline 19 & Majority vote requirement to approve mergers & Charter (1) & $-[1]$ & $-[1]$ & $-[0]$ & $-[0]$ & $-[0]$ \\
\hline 20 & Majority vote requirement to amend bylaws & Charter (2) & $-[1]$ & $-[1]$ & $-[13]$ & $-[1]$ & $-[1]$ \\
\hline 21 & Shareholder may act by written consent & Charter (3) & $0[1]$ & $1[1]$ & $0[0]$ & $0[0]$ & $1[0]$ \\
\hline 22 & Single class, common, no blank check & Charter (4) & $97[100]$ & $100[100]$ & $99[100]$ & $99[100]$ & $100[99]$ \\
\hline 23 & Opting out of any anti-takeover provisions & Anti-take. (1) & $0[1]$ & $99[1]$ & $98[0]$ & $96[0]$ & $99[0]$ \\
\hline 24 & Control-share acquisition & Anti-take. (2) & $0[-]$ & $0[-]$ & $0[-]$ & $0[-]$ & $0[-]$ \\
\hline 25 & Cash out statue & Anti-take. (3) & $0[-]$ & $0[-]$ & $0[-]$ & $0[-]$ & $0[-]$ \\
\hline 26 & Freeze out statue & Anti-take. (4) & $0[-]$ & $0[-]$ & $0[-]$ & $0[-]$ & $0[-]$ \\
\hline 27 & Fair Price provisions & Anti-take. (5) & $0[-]$ & $0[-]$ & $0[-]$ & $0[-]$ & $0[-]$ \\
\hline 28 & Stakeholders laws & Anti-take. (6) & $0[-]$ & $0[-]$ & $0[-]$ & $0[-]$ & $0[-]$ \\
\hline 29 & Poison pill endorsement & Anti-take. (7) & $0[-]$ & $0[-]$ & $0[-]$ & $0[-]$ & $0[-]$ \\
\hline 30 & Option repricing prohibited & Comp. (1) & $2[0]$ & $2[61]$ & $2[98]$ & $89[100]$ & $12[88]$ \\
\hline 31 & No firm loan to executives for exercising option & Comp. (2) & $-[1]$ & $-[1]$ & $-[44]$ & $-[90]$ & $-[48]$ \\
\hline 32 & Company expenses options & Comp. (3) & $5[2]$ & 7 [25] & $78[73]$ & $95[98]$ & $98[92]$ \\
\hline 33 & No interlocks among comp. committee members & Comp. (4) & $6[6]$ & $2[21]$ & $91[53]$ & $12[63]$ & $1[99]$ \\
\hline 34 & Option grant align with performance & Comp. (5) & $42[12]$ & $46[29]$ & $39[44]$ & $41[43]$ & $54[39]$ \\
\hline 35 & Directors receive all / portion of fees in stock & Comp. (6) & $40[33]$ & $36[13]$ & $4[3]$ & $31[1]$ & $3[1]$ \\
\hline 36 & ISS deemed option plan costs as reasonable & Comp. (7) & $72[36]$ & $87[55]$ & $85[50]$ & $83[52]$ & $98[51]$ \\
\hline 37 & Stock incentive plan adopt with shareh. approval & Comp. (8) & $100[83]$ & $99[63]$ & $100[61]$ & $99[63]$ & $95[49]$ \\
\hline 38 & No non-empl. directors with pension plan & Comp. (9) & $96[83]$ & $96[34]$ & $98[99]$ & 98 [99] & $100[100]$ \\
\hline 39 & No option repricing within the last three years & Comp. (10) & $10[95]$ & $98[73]$ & $100[98]$ & 99 [99] & $100[53]$ \\
\hline 40 & Outside directors meet without CEO and disclose & Progressive (1) & $1[0]$ & $12[5]$ & $28[4]$ & $17[7]$ & $22[2]$ \\
\hline 41 & Outside advisor available to the board & Progressive (2) & $86[0]$ & $91[9]$ & $96[4]$ & $98[4]$ & $81[6]$ \\
\hline 42 & Directors resign upon a job change & Progressive (3) & $0[0]$ & $0[1]$ & $0[0]$ & $0[0]$ & $0[1]$ \\
\hline 43 & Board approved CEO succession plan & Progressive (4) & $1[1]$ & $38[23]$ & $33[34]$ & $40[73]$ & $67[12]$ \\
\hline 44 & Performance of the board is reviewed regularly & Progressive (5) & $6[4]$ & $61[36]$ & $81[99]$ & $90[99]$ & $92[17]$ \\
\hline 45 & Retirement age / term limit for directors & Progressive (6) & $9[5]$ & $26[15]$ & $41[79]$ & $23[47]$ & $2[24]$ \\
\hline 46 & Stock ownership guidelines for Directors & Ownership (1) & $3[0]$ & $7[0]$ & $3[0]$ & $2[0]$ & $4[0]$ \\
\hline 47 & Stock ownership guidelines for Executives & Ownership (2) & $15[0]$ & $30[1]$ & $29[1]$ & $44[1]$ & $40[1]$ \\
\hline 48 & Directors with $>1$ year of service own stock & Ownership (3) & $60[78]$ & $64[33]$ & $61[19]$ & $58[16]$ & $54[19]$ \\
\hline 49 & Officers \& directors stock ownership & Ownership (4) & $20[7]$ & $19[8]$ & $39[24]$ & $42[28]$ & $37[66]$ \\
\hline 50 & Directors participate in director educat. program & Education (1) & $0[0]$ & $0[0]$ & $0[1]$ & $0[1]$ & $0[1]$ \\
\hline
\end{tabular}

Panel B. CGQ Provisions and Descriptive Data: UK [GER]

\begin{tabular}{|c|c|c|c|c|c|c|c|c|c|c|c|c|}
\hline \multicolumn{2}{|c|}{$\mathbf{N}$} & \multirow{2}{*}{$\begin{array}{c}\text { Year: Sample } \\
2003-2007\end{array}$} & \multicolumn{2}{|c|}{ Mean } & \multicolumn{2}{|c|}{ Median } & \multicolumn{2}{|c|}{ StD } & \multicolumn{2}{|c|}{ Min } & \multicolumn{2}{|c|}{ Max } \\
\hline 1677 & [409] & & 44.2 & [35.5] & 44.7 & {$[36.6]$} & 8.1 & {$[11.4]$} & 19.1 & {$[12.2]$} & 61.7 & {$[63.4]$} \\
\hline 174 & {$[83]$} & 2003 & 30.9 & {$[23.0]$} & 31.9 & {$[22.0]$} & 4.8 & [4.3] & 19.1 & [14.6] & 46.8 & {$[41.5]$} \\
\hline 179 & [80] & 2004 & 39.8 & [26.8] & 38.3 & [24.4] & 7.0 & {$[9.0]$} & 21.3 & [12.2] & 59.6 & {$[46.3]$} \\
\hline 459 & [80] & 2005 & 45.3 & [40.5] & 44.7 & [39.0] & 6.9 & [7.2] & 23.4 & [22.0] & 61.7 & {$[61.0]$} \\
\hline 450 & [83] & 2006 & 48.7 & [45.9] & 48.9 & [46.3] & 6.2 & {$[7.2]$} & 23.4 & [29.3] & 61.7 & {$[63.4]$} \\
\hline 415 & [83] & 2007 & 45.7 & [41.0] & 46.8 & [41.5] & 5.5 & [7.3] & 25.5 & [26.8] & 61.7 & {$[63.4]$} \\
\hline
\end{tabular}

Notes: Compliance rates for the years 2003 to 2007 represent the percentage of firms with minimum governance standards. The minimum governance standards are based on RiskMetrics' Corporate Governance Quotient Indicator Definition for non-US companies (version 3.4.1) last updated December 2007. 
Table 3 - 2 reports the individual ISS rating criteria for the UK and Germany, and the corresponding benchmark values required as minimum governance standards, the resulting compliance rates over the five years panel and additional descriptive data for the sample compliance rates. Our data reveals a corresponding compliance rate of around $30.9 \%$ for UK firms and $23 \%$ for German firms in 2003, which underlines that the compliance levels in both countries are lower than in the U.S., for which Brown and Caylor (2009), using 2003 data, report an average compliance rate over all single ISS provisions of $44 \%$. Although the compliance rate with ISS governance standards shows an upwards trend for our sample years 2003-2007, with an increase in the average compliance rate of almost 15 percentage points for UK firms and 20 percentage points for German firms over five years (Table 3 - 2, Panel B, mean values), the overall compliance rates remain on a relatively low level. The highest rated UK firm (German firm) in 2003 exhibits a compliance rate of $46.8 \%$ (41.5\%), whereas the highest rated firm in 2007 complies with $61.7 \%$ (63.4\%) of all 47 CGQ criteria (41 CGQ criteria).

Table 3 - 3: Isolation of the Incremental Contribution of CG Rating Agencies

\begin{tabular}{ccc}
\hline Panel A: Conceptual Level: Two-way decomposition of the CGQ rating & \\
\hline CGQ & Public Information (PI) & TECHNOLOGY (TECH) \\
$\begin{array}{c}\text { Commercial } \\
\text { corporate } \\
\text { governance } \\
\text { rating }\end{array}$ & $\begin{array}{c}\text { Publicly available information } \\
\text { underlying the CGQ rating (ISS } \\
\text { rating criteria, see Table 3 - 2) }\end{array}$ & $\begin{array}{c}\text { All non-public information } \\
\text { factors underlying the CGQ } \\
\text { rating including weighting } \\
\text { expertise and access to private } \\
\text { information }\end{array}$
\end{tabular}

Panel B: Regression Level: Two-way decomposition of the CGQ rating

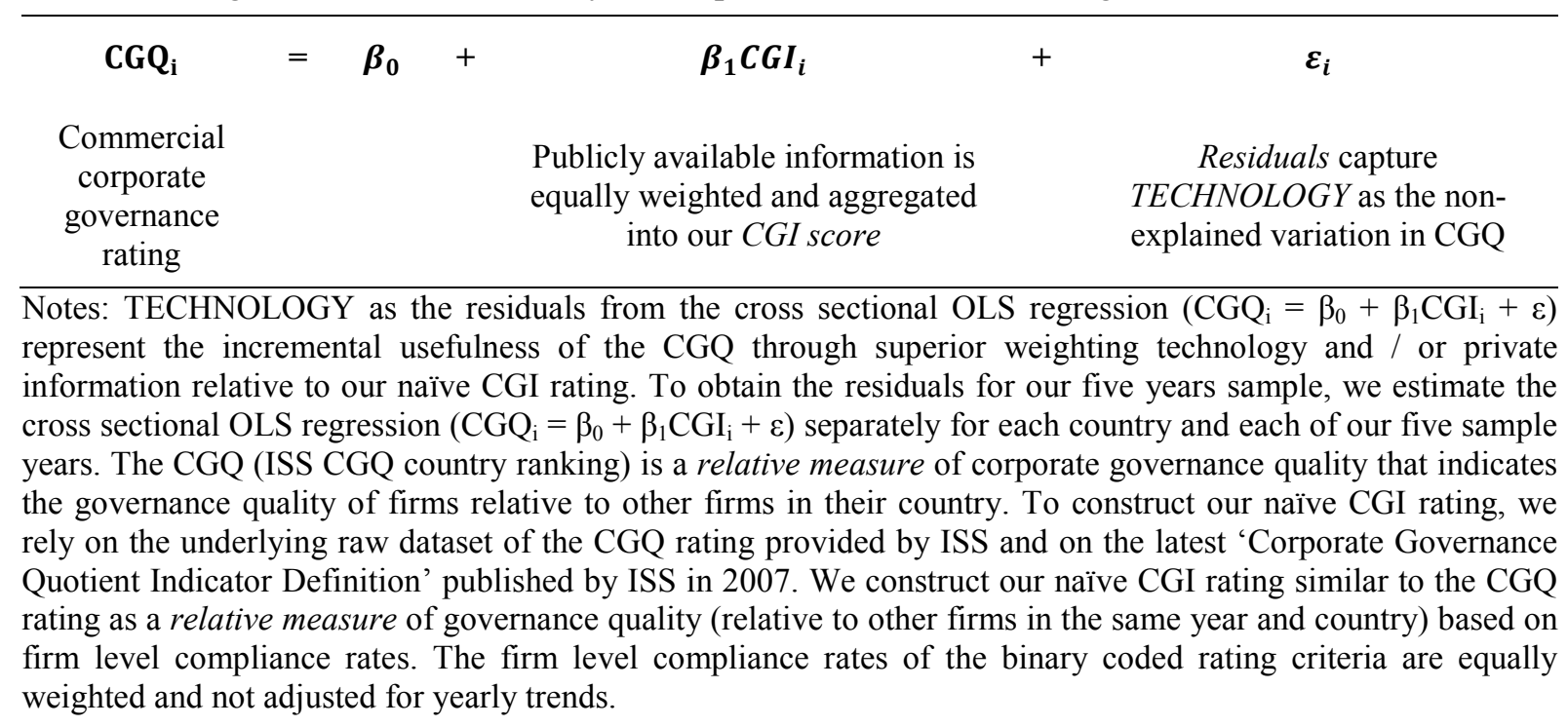


For each firm, we construct the naïve CGI score as an equally weighted score of all compliance rates for each firm with ISS's governance criteria. The CGI variable is an indicator of the fraction of the CGQ rating which is based on processing publicly available information on firm's governance structures. Consistent with the CGQ rating, a firm's CGI score of $66 \%$, for example, indicates that the firm's compliance with ISS minimum requirements was higher than the compliance in $66 \%$ of all other rated firms in the same year and country. ${ }^{56}$ The potential additional explanatory power of the commercial rating over the naïve CGI score is captured by our measure of ISS's rating technology, TECHNOLOGY. This measure indicates the incremental value added by the rating agency's weighting technology, including potential private information. TECHNOLOGY is measured as the residuals from regressing the CGQ rating on the naive CGI score. Table 3 - 3 illustrates our approach to decomposing the CGQ rating.

\subsubsection{Firm Value and Control Variables}

We build on a literature of finance and governance studies that employ Tobin's Q as a key measure of firm value that reflects growth opportunities and investment possibilities from a capital market perspective (e.g., Morck et al., 1988; McConnell and Servaes, 1990; Lang and Stulz, 1994; Daines, 2001; Gompers et al., 2003; Drobetz et al., 2004; Beiner et al., 2006; Brown and Caylor, 2006; Aggarwal et al., 2009; Bebchuk et al., 2009; Renders et al., 2010; Ammann et al., 2011). This literature frames Tobin's Q as a comparably robust measure of firm value (Adam and Goyal, 2008). While we note that there are concerns with this measure, we follow prior literature and rely on Tobin's $Q$ as our main measure of firm value. ${ }^{57}$ Tobin's $\mathrm{Q}$ is computed as the market value of assets divided by book value of total assets, where the market value of assets is book value of assets plus the market value of common stock less the sum of book value of common stock. We winsorize ${ }^{58}$ Tobin's $\mathrm{Q}$ by extreme percentiles to control for outliers (e.g., Brown and Caylor, 2006/2009), and use it in log form (e.g., Bebchuk

\footnotetext{
${ }^{56}$ For computational details on our relative CGI score, see Appendix 3 - 1.

${ }^{57}$ For example, Daines et al. (2010, p. 451) note that "Tobin's Q, typically measured using some variant of the market-to-book ratio, is commonly used as an indicator of firm value in accounting and finance research." Although they state some concerns about the practicability of such ratios to comprehensively measure firm value, they also examine Tobin's Q due to "its continued popularity in academic corporate finance research".

${ }^{58}$ Values less (greater) than the $1^{\text {th }}\left(99^{\text {th }}\right)$ percentile are set equal to the value of the $1^{\text {th }}\left(99^{\text {th }}\right)$ percentile.
} 
et al., 2009). ${ }^{59}$

For our control variables, we follow prior literature and use (1) (the natural logarithm of) book value of total assets to measure size (e.g., Gompers et al., 2003; Brown and Caylor, 2006; Drobetz et al., 2004), (2) three-year's average growth in net sales to control for growth (e.g., Aggarwal et al., 2009; Beiner et al., 2006; Renders et al., 2010), (3) total debt to total assets to control for leverage (e.g., Aggarwal et al., 2009; Bebchuk et al., 2009; Drobetz et al., 2004), (4) number of shares in free float divided by total shares outstanding to control for ownership (e.g., Aggarwal et al., 2009; Renders et al., 2010; Ammann et al., 2011), (5) ratio of property, plant \& equipment (PPE) divided by total assets to control for capital-intensity (e.g., Aggarwal et al., 2009; Renders et al., 2010; Klapper and Love, 2004), and finally (6) membership in the FTSE100 or DAX index for UK and German firms, respectively, to identify blue chip firms (e.g., Gompers et al., 2003; Drobetz et al., 2004). In the robustness section we show that our results are unaffected by the inclusion of additional (frequently used) control variables and by applying stepwise regression technique to statistically select the set of control variables. Data for our firm value measure as well as our control variables is obtained from Datastream / Worldscope.

\subsection{Results}

\subsubsection{Sample Selection and Descriptive Statistics}

Table 3 - 4 reports descriptive statistics for all test and control variables used in our analyses for the three samples we use in our respective analyses, the full sample comprised of both UK and German firms, the UK firms sample, and the German firms sample. The full sample includes 1,677 UK firm-year (UK sample) and 409 German firm-year observations (German sample) over the time period 2003 - 2007. This sample choice reflects coverage of around $84 \%$ of all UK CGQ country scores and of around 92\% of all German CGQ country scores, and reflects one third (34\%) of all non-U.S. CGQ 'Country Scores' marketed by ISS during the 2003-2007 period under investigation. Because both the CGQ and the CGI rating represent relative measures of governance quality, we do not expect and do not find substantial differences in the distribution characteristics of the ratings between the UK and

\footnotetext{
${ }^{59}$ The $\log$ form of Tobin's Q is frequently used in the literature to proxy firm value (e.g., Daines, 2001; Bebchuk et al., 2009). We use the log form of Tobin's Q as well to statistically correct for a highly left-skewed distribution of our firm value proxy. However, as documented in the robustness section, our main results are unaffected by both measurement transformations (winsorizing and using logarithms).
} 
Germany. The control variables, however, reflect the different institutional settings, as we document higher Tobin's Q ratios, higher growth ratios, and higher capital intensity for UK firms compared to German firms.

Table 3 - 4: Descriptive Data

Panel A. Governance (CGQ \& CGI) Variables (values pooled for 2003 to 2007)

\begin{tabular}{lccccccc}
\hline & Sample & N & Mean & Median & StD & Min & Max \\
\hline CGQ & UK \& GER & 2086 & 50.6 & 50.7 & 29.07 & 0 & 100 \\
& UK & 1677 & 50.6 & 50.9 & 29.0 & 0 & 100 \\
& GER & 409 & 50.8 & 50.6 & 29.4 & 1.1 & 100 \\
\hline CGI & UK \& GER & 2086 & 44.7 & 41.2 & 29.0 & 0 & 100 \\
& UK & 1677 & 44.9 & 41.2 & 28.7 & 0 & 100 \\
& GER & 409 & 44.0 & 39.0 & 29.9 & 0 & 100 \\
\hline
\end{tabular}

Panel B. Valuation and Control Variables (values pooled for 2003 to 2007)

\begin{tabular}{|c|c|c|c|c|c|c|c|}
\hline & Sample & $\mathbf{N}$ & Mean & Median & StD & Min & Max \\
\hline \multirow{3}{*}{ Tobin's Q } & UK \& GER & 2086 & 1.77 & 1.42 & 1.19 & .44 & 16.14 \\
\hline & UK & 1677 & 1.84 & 1.50 & 1.24 & .44 & 16.14 \\
\hline & GER & 409 & 1.47 & 1.14 & .92 & .46 & 7.25 \\
\hline \multirow{3}{*}{$\begin{array}{l}\text { Total Assets } \\
(\text { in Billion } € \text { ) }\end{array}$} & UK \& GER & 2086 & 27.8 & 1.34 & 120 & 0.003 & 1,480 \\
\hline & UK & 1677 & 20 & 1.04 & 106 & 0.003 & 1,480 \\
\hline & GER & 409 & 59.7 & 5.6 & 162 & 0.012 & 1,120 \\
\hline \multirow{3}{*}{$\begin{array}{l}\text { Leverage } \\
(\text { in } \%)\end{array}$} & UK \& GER & 2086 & 23.4 & 21.7 & 19.5 & 0 & 167 \\
\hline & UK & 1677 & 23.8 & 22.1 & 19.9 & 0 & 167 \\
\hline & GER & 409 & 21.6 & 19.3 & 17.9 & 0 & 87.8 \\
\hline \multirow{3}{*}{$\begin{array}{l}\text { Growth } \\
\text { (in \%) }\end{array}$} & UK \& GER & 2086 & 13.1 & 6.8 & 74.3 & -52.9 & 2,979 \\
\hline & UK & 1677 & 14.4 & 7.7 & 81.7 & -45.0 & 2,979 \\
\hline & GER & 409 & 7.6 & 4.4 & 28.0 & -52.9 & 319 \\
\hline \multirow{3}{*}{$\begin{array}{l}\text { Freefloat } \\
(\text { in } \%)\end{array}$} & UK \& GER & 2086 & 63.1 & 64 & 23.0 & 2 & 100 \\
\hline & UK & 1677 & 62.8 & 63 & 22.2 & 10 & 100 \\
\hline & GER & 409 & 64.1 & 67 & 26.0 & 2 & 100 \\
\hline \multirow{3}{*}{$\begin{array}{l}\text { Capital- } \\
\text { Intensity } \\
(\text { in } \%) \\
\end{array}$} & UK \& GER & 2086 & 26.8 & 18.6 & 25.8 & 0 & 99 \\
\hline & UK & 1677 & 28.6 & 19.7 & 27.3 & 0 & 99 \\
\hline & GER & 409 & 19.7 & 16.2 & 16.3 & 0 & 72.6 \\
\hline \multirow{3}{*}{$\begin{array}{l}\text { Index } \\
\text { Membership }\end{array}$} & UK \& GER & 2086 & .247 & 0 & .431 & 0 & 1 \\
\hline & UK & 1677 & .224 & 0 & .417 & 0 & 1 \\
\hline & GER & 409 & .344 & 0 & .475 & 0 & 1 \\
\hline
\end{tabular}

Panel C. Exclusion Restrictions (values pooled for 2003 to 2007)

\begin{tabular}{lccccccc}
\hline & Sample & N & Mean & Median & StD & Min & Max \\
\hline Pension & UK \& GER & 2086 & 1.04 & 0 & 2.75 & 0 & 71 \\
Funds & UK & 1677 & 1.26 & 0 & 2.97 & 0 & 71 \\
Holding & GER & 409 & 0.15 & 0 & 1.32 & 0 & 13 \\
\hline DPS & UK \& GER & 2075 & .325 & .097 & 1.65 & 0 & 41.5 \\
& UK & 1667 & .209 & .082 & 1.57 & 0 & 41.5 \\
& GER & 408 & .799 & .500 & 1.89 & 0 & 34.8 \\
\hline
\end{tabular}

Notes: The table presents the descriptive statistics of all variables used in this study. CGQ stands for ISS's Corporate Governance Quotient; CGI is our naïve corporate governance rating based on the CGQ raw dataset; Tobin's $\mathrm{Q}$ is a measure of firm value; total assets is measured in EUR billion; leverage is total debt to total assets; growth is 3 years average growth in net sales; free float is number of shares as free float to total shares outstanding; capital-intensity is PPE to total assets; index membership indicates blue chip firms based on FTSE100 for UK firms and DAX30 for GER firms; pension funds holding is shares held by pension funds to total shares outstanding; DPS are dividend per share. 
Table 3 - 5: Correlation Matrix

Panel A. Correlations between Governance Ratings and Valuation / Control Variables: UK \& GER

\begin{tabular}{|c|c|c|c|c|c|c|c|c|c|c|}
\hline $\mathrm{N}=2086$ & & 1 & 2 & 3 & 4 & 5 & 6 & 7 & 8 & 9 \\
\hline CGQ & 1 & 1 & & & & & & & & \\
\hline CGI & 2 & $0.78^{* * * *}$ & 1 & & & & & & & \\
\hline Tobin's Q & 3 & 0.03 & $0.06^{* * *}$ & 1 & & & & & & \\
\hline Size & 4 & $0.28 * * *$ & $0.28 * * *$ & $-0.42 * * *$ & 1 & & & & & \\
\hline Leverage & 5 & $0.14^{* * *}$ & $0.14^{* * *}$ & $-0.20 * * *$ & $0.35^{* * *}$ & 1 & & & & \\
\hline Growth & 6 & $-0.07 * * *$ & -0.03 & $0.14 * * *$ & $-0.08 * * *$ & $-0.08 * * *$ & 1 & & & \\
\hline Freefloat & 7 & $0.13 * * *$ & $0.13^{* * *}$ & 0.03 & $0.14 * * *$ & $0.06^{* * *}$ & 0.03 & 1 & & \\
\hline Capital-Int. & 8 & $0.09^{* * *}$ & $0.09^{* * *}$ & $-0.04 *$ & 0.02 & $0.30^{* * *}$ & $-0.11 * * *$ & $-0.05 * *$ & 1 & \\
\hline Index Memb. & 9 & $0.18^{* * *}$ & $0.18^{* * *}$ & $-0.09 * * *$ & $0.58^{* * *}$ & $0.10^{* * *}$ & -0.01 & $0.14^{* * *}$ & $0.07 * * *$ & 1 \\
\hline
\end{tabular}

Panel B. Correlations between Governance Ratings and Valuation / Control Variables: UK

\begin{tabular}{|c|c|c|c|c|c|c|c|c|c|c|}
\hline $\mathrm{N}=1677$ & & 1 & 2 & 3 & 4 & 5 & 6 & 7 & 8 & 9 \\
\hline CGQ & 1 & 1 & & & & & & & & \\
\hline CGI & 2 & $0.79 * * *$ & 1 & & & & & & & \\
\hline Tobin's Q & 3 & 0.03 & 0.04 & 1 & & & & & & \\
\hline Size & 4 & $0.28 * * *$ & $0.35 * * *$ & $-0.39 * * *$ & 1 & & & & & \\
\hline Leverage & 5 & $0.14 * * *$ & $0.16^{* * *}$ & $-0.17 * * *$ & $0.37^{* * *}$ & 1 & & & & \\
\hline Growth & 6 & $-0.10^{* * *}$ & $-0.05 * *$ & $0.09 * * *$ & -0.03 & $-0.08 * * *$ & 1 & & & \\
\hline Freefloat & 7 & $0.12 * * *$ & $0.12 * * *$ & $0.09^{* * *}$ & $0.13^{* * *}$ & 0.04 & $0.05 * *$ & 1 & & \\
\hline Capital-Int. & 8 & $0.08 * * *$ & $0.09^{* * *}$ & $-0.07 * * *$ & $0.05 * *$ & $0.33^{* * *}$ & $-0.13 * * *$ & $-0.07 * * *$ & 1 & \\
\hline Index Memb. & 9 & $0.14 * * *$ & $0.18^{* * *}$ & $-0.04 *$ & $0.57 * * *$ & $0.09^{* * *}$ & 0.04 & $0.08 * * *$ & $0.06^{* * *}$ & 1 \\
\hline
\end{tabular}

Panel C. Correlations between Governance Ratings and Valuation / Control Variables: GER

\begin{tabular}{|c|c|c|c|c|c|c|c|c|c|c|}
\hline $\mathrm{N}=409$ & & 1 & 2 & 3 & 4 & 5 & 6 & 7 & 8 & 9 \\
\hline CGQ & 1 & 1 & & & & & & & & \\
\hline CGI & 2 & $0.75 * * *$ & 1 & & & & & & & \\
\hline Tobin's Q & 3 & 0.03 & $0.11^{* *}$ & 1 & & & & & & \\
\hline Size & 4 & $0.29 * * *$ & $0.12 * * *$ & $-0.37 * * *$ & 1 & & & & & \\
\hline Leverage & 5 & $0.15^{* * *}$ & 0.07 & $-0.41 * * *$ & $0.46^{* * *}$ & 1 & & & & \\
\hline Growth & 6 & 0.03 & 0.06 & $0.17 * * *$ & $-0.15^{* * *}$ & $-0.09 *$ & 1 & & & \\
\hline Freefloat & 7 & $0.16^{* * *}$ & $0.15^{* * *}$ & $-0.11 * *$ & $0.17 * * *$ & $0.15^{* * *}$ & -0.03 & 1 & & \\
\hline Capital-Int. & 8 & $0.15^{* * *}$ & 0.07 & -0.04 & -0.03 & $0.15^{* * *}$ & -0.08 & 0.06 & 1 & \\
\hline Index Memb. & 9 & $0.32 * * *$ & $0.18^{* * *}$ & $-0.11 * *$ & $0.60 * * *$ & $0.17 * * *$ & $-0.10 * *$ & $0.34 * * *$ & $0.18^{* * * *}$ & 1 \\
\hline
\end{tabular}

Panel D. Correlations between CGQ and CGI Ratings per Year

\begin{tabular}{|c|c|c|c|c|c|c|c|}
\hline & Sample & CGI '03 & CGI'04 & CGI'05 & CGI '06 & CGI'07 & CGI '03-'07 \\
\hline \multirow[t]{3}{*}{ CGQ } & UK \& GER & $0.77 * * *$ & $0.82 * * *$ & $0.82 * * *$ & $0.76^{* * *}$ & $0.75^{* * * *}$ & $0.78^{* * *}$ \\
\hline & UK & $0.77 * * *$ & $0.79 * * *$ & $0.84 * * *$ & $0.76^{* * *}$ & $0.77^{* * *}$ & $0.79^{* * *}$ \\
\hline & GER & $0.76^{* * *}$ & $0.89^{* * *}$ & $0.72 * * *$ & $0.71 * * *$ & $0.66^{* * *}$ & $0.75^{* * *}$ \\
\hline
\end{tabular}

Panel E. Time-Series Correlations between two consecutive Ratings

\begin{tabular}{lccccc}
\hline & Sample & $\mathbf{2 0 0 3 / 2 0 0 4}$ & $\mathbf{2 0 0 4 / 2 0 0 5}$ & $\mathbf{2 0 0 5 / 2 0 0 6}$ & $\mathbf{2 0 0 6 / 2 0 0 7}$ \\
\hline CGQ & UK \& GER & $0.37^{* * *}$ & $0.42^{* * *}$ & $0.57^{* * *}$ & $0.47^{* * *}$ \\
& UK & $0.40^{* * *}$ & $0.49^{* * *}$ & $0.58^{* * *}$ & $0.46^{* * *}$ \\
& GER & $0.29^{* * *}$ & $0.30^{* * *}$ & $0.47^{* * *}$ & $0.49^{* * *}$ \\
\hline CGI & UK \& GER & $0.39^{* * *}$ & $0.37^{* * *}$ & $0.59^{* * *}$ & $0.54^{* * *}$ \\
& UK & $0.49^{* * *}$ & $0.43^{* * *}$ & $0.60^{* * *}$ & $0.56^{* * *}$ \\
& GER & $0.23^{* *}$ & $0.29^{* *}$ & $0.57^{* * *}$ & $0.46^{* * *}$ \\
\hline
\end{tabular}

Notes: This table reports non-parametric Spearman correlation coefficients. CGQ stands for ISS's Corporate Governance Quotient; CGI is our naïve corporate governance rating based on the CGQ raw dataset; Tobin's Q is a measure of firm value (Q is winsorized at $1 \%$ level and is used in $\log$ form); total assets is measured in EUR billion (used in $\log$ form); leverage is total debt to total assets; growth is 3 years average growth in net sales; free float is number of shares as free float to total shares outstanding; capital-intensity is PPE to total assets; index membership indicates blue chip firms based on FTSE100 for UK firms and DAX30 for GER firms. The underlying samples is as indicated. $* * *(* *)(*)$ indicates significance at $1 \%(5 \%)(10 \%)$, two-tailed level. 
For each of our three samples, panels A, B, and C of Table 3 - 5 respectively report Spearman correlations between the governance ratings, the main test variable (firm value), and the control variables. While no significant correlation between the CGQ rating and our measure of firm value can be observed, the CGI rating, in contrast, is significantly positively correlated with Tobin's Q for the full sample and for the German sample. Also, most correlations between both governance ratings and the control variables are significant. . Panel D of Table 3 - 5 reports correlations between the CGQ rating and our naïve CGI rating over time, which range from 0.75 to 0.82 for the full sample. The variation of this correlation over time suggests that ISS most likely adjusts its CGQ rating methodology and weighting periodically.

Panel E of Table 3 - 5 reports time-series correlations for both governance ratings across the respective samples. For our five years observation period, these correlations range from 0.40 to 0.58 (from 0.29 to 0.49 ) for the CGQ rating, and from 0.43 to 0.60 (from 0.23 to 0.57) for the naïve CGI rating in the UK sample (German sample). This suggests a substantial degree of variation of governance quality over time, which is particularly pronounced for the German sample and stands in contrast to the maintained assumption in prior work that firmlevel governance characteristics are sticky (e.g., Brown et al., 2011; Bauer et al., 2004, 2008). For instance, Daines et al. (2010) report a relatively high time-series correlation of 0.85 between two consecutive CGQ ratings in 2005 and 2006 for the U.S. One explanation for the low time-series correlation of both governance ratings is the increasing soft law and hard low regulation of governance practices, in particular in Germany. During our sample period, various legislative acts were passed in Germany (for an overview, see, e.g., Hopt, 2011; Cromme, 2005). A second, related explanation is that these developments were paralleled by increased disclosure of governance-related information, thus providing an improved informational basis for firms such as ISS. For example, since 2006 only, German listed firms have been mandated to report executive compensation individually for each member of the management board (Hitz and Werner, 2012).

\subsubsection{Regression Results}

Table 3 - 6 (Panel A and B) presents the results of estimating our two basic regression models for the three samples under investigation. The signs and significance levels for the control variables are broadly in line with prior findings (e.g., Brown and Caylor, 2006). The 
explanatory power of the regression models is also comparable to prior governance studies, with adjusted $\mathrm{R}^{2} \mathrm{~s}$ ranging from 0.3162 to 0.3773 (e.g., Drobetz et al., 2004). As predicted, the coefficient estimate of the commercial CGQ rating obtains a positive sign but turns out significant only for the full sample and the UK sample (Model 1, Panel A, and Model 1 and 4, Panel B; Table 3 - 6). Therefore, we find evidence in support of our first prediction that governance quality, as reflected in the commercial CGQ rating, is positively associated with firm value, at least for the UK.

The regression models based on the decomposed commercial rating yield positive and significant coefficients only for the naïve CGI rating, but not for the TECHNOLOGY variable (Model 3, Panel A, and Model 3 and 6, Panel B; Table 3 - 6). The coefficients for the naïve CGI rating are positive and significant for all three samples (at the $1 \%$ and $5 \%$ level), whereas the coefficients of TECHNOLOGY obtain the predicted significant positive coefficient in none of different specifications. Other than expected, the rating agency's proprietary technology (TECHNOLOGY), reflecting its weighting skill methodology and its access to private information does not appear to provide incremental positive explanatory power for firm value beyond the raw publicly available data captured by the naïve CGI rating. We therefore find no evidence in support of our second prediction.

Finally, we find no evidence in support of our third prediction that the CGQ rating is comparatively more suited for capturing governance quality for the UK with its shareholder model of corporate governance. Panel A of Table 3 - 6 (Model 5 and 6) reports results from rerunning the initial regression for the full sample, augmented by interactions of the governance variables CGI and TECHNOLOGY with an indicator variable for UK firms. Although both interaction terms based on TECHNOLOGY and UK firms obtain positive signs, none of them is statistically (and economically) significant at conventional levels. This suggests that irrespective of the institutional background, CGQ ratings do not provide incremental power for explaining firm value. This in turn indicates that our findings that refute our second prediction cannot be attributed to a 'one-size-fits-all' applied by ISS in assessing governance quality. ${ }^{60}$ Rather, these results hint at a systematic deficiency of the rating process in capturing value-relevant information.

\footnotetext{
${ }^{60}$ Regressions of the CGQ (CGI) on an all six CGQ subcategories reveal that (i) board and audit (compensation) characteristics play a more (a less) important role in the UK CGQ compared to the German CGQ rating. Moreover, (ii) progressive practice and ownership characteristics play a less important role in the CGQ rating compared to our naïve CGI rating in both country settings (Appendix 3 - 8).
} 
Table 3 - 6: Regression Results - Basic Model

Panel A. Basic model for a combined UK \& GER sample

\begin{tabular}{|c|c|c|c|c|c|c|c|}
\hline \multirow{2}{*}{ Independent Variables } & \multirow{2}{*}{$\begin{array}{l}\text { Pred. } \\
\text { Sign }\end{array}$} & \multicolumn{6}{|c|}{ Firm Value Measure: Tobin's Q (dependent variable) } \\
\hline & & Model 1 & Model 2 & Model 3 & Model 4 & Model 5 & Model 6 \\
\hline Intercept & & $\begin{array}{c}2.2525 * * * \\
(7.98)\end{array}$ & $\begin{array}{c}2.2973 * * * \\
(8.14)\end{array}$ & $\begin{array}{c}2.2948 * * * \\
(8.12)\end{array}$ & $\begin{array}{c}2.3009^{* * *} \\
(8.00)\end{array}$ & $\begin{array}{c}2.2939 * * * \\
(8.12)\end{array}$ & $\begin{array}{c}2.3000^{* * * *} \\
(8.00)\end{array}$ \\
\hline CGQ & + & $\begin{array}{c}.0012 * * * \\
(3.08)\end{array}$ & & & & & \\
\hline CGI & + & & $\begin{array}{c}.0016 * * * \\
(4.27)\end{array}$ & $\begin{array}{c}.0016 * * * \\
(4.26)\end{array}$ & $\begin{array}{c}.0015^{*} \\
(1.88)\end{array}$ & $\begin{array}{c}.0016 * * * \\
(4.27)\end{array}$ & $\begin{array}{c}.0015 * \\
(1.88)\end{array}$ \\
\hline TECHNOLOGY & + & & & $\begin{array}{l}-.0001 \\
(-0.16)\end{array}$ & $\begin{array}{r}-.0001 \\
(-0.16)\end{array}$ & $\begin{array}{l}-.0002 \\
(-0.16)\end{array}$ & $\begin{array}{r}-.0002 \\
(-0.15)\end{array}$ \\
\hline UK $\times$ CGI & + & & & & $\begin{array}{l}.0001 \\
(0.13)\end{array}$ & & $\begin{array}{l}.0001 \\
(0.13)\end{array}$ \\
\hline UK $\times$ TECHNOLOGY & + & & & & & $\begin{array}{l}.0001 \\
(0.08) \\
\end{array}$ & $\begin{array}{l}.0001 \\
(0.08) \\
\end{array}$ \\
\hline UK & & $\begin{array}{c}.1023 * * \\
(2.38)\end{array}$ & $\begin{array}{c}.0986^{* *} \\
(2.30)\end{array}$ & $\begin{array}{c}.0988^{* *} \\
(2.31)\end{array}$ & $\begin{array}{l}.0930 \\
(1.51)\end{array}$ & $\begin{array}{c}.0988 * * \\
(2.32)\end{array}$ & $\begin{array}{l}.0931 \\
(1.51)\end{array}$ \\
\hline SIZE & & $\begin{array}{c}-.0992 * * * \\
(-7.74)\end{array}$ & $\begin{array}{c}-.1016^{* * * *} \\
(-7.95)\end{array}$ & $\begin{array}{c}-.1015^{* * *} \\
(-7.92)\end{array}$ & $\begin{array}{c}-.1016^{* * * *} \\
(-7.90)\end{array}$ & $\begin{array}{c}-.1015 * * * \\
(-7.92)\end{array}$ & $\begin{array}{c}-.1016 * * * \\
(-7.90)\end{array}$ \\
\hline LEVERAGE & & $\begin{array}{l}.0975 \\
(1.11)\end{array}$ & $\begin{array}{l}.0984 \\
(1.12)\end{array}$ & $\begin{array}{l}.0986 \\
(1.12)\end{array}$ & $\begin{array}{l}.0986 \\
(1.12)\end{array}$ & $\begin{array}{l}.0987 \\
(1.12)\end{array}$ & $\begin{array}{l}.0986 \\
(1.12)\end{array}$ \\
\hline GROWTH & & $\begin{array}{l}.0156 \\
(1.46)\end{array}$ & $\begin{array}{l}.0154 \\
(1.49)\end{array}$ & $\begin{array}{l}.0154 \\
(1.49)\end{array}$ & $\begin{array}{l}.0155 \\
(1.50)\end{array}$ & $\begin{array}{l}.0154 \\
(1.49)\end{array}$ & $\begin{array}{l}.0155 \\
(1.50)\end{array}$ \\
\hline FREEFLOAT & & $\begin{array}{l}-.0003 \\
(-0.44)\end{array}$ & $\begin{array}{l}-.0004 \\
(-0.56)\end{array}$ & $\begin{array}{l}-.0004 \\
(-0.56)\end{array}$ & $\begin{array}{l}-.0004 \\
(-0.56)\end{array}$ & $\begin{array}{l}-.0004 \\
(-0.56)\end{array}$ & $\begin{array}{l}-.0004 \\
(-0.56)\end{array}$ \\
\hline CAPITAL_INTENSITY & & $\begin{array}{c}-.3218 * * * \\
(-6.01)\end{array}$ & $\begin{array}{c}-.3254 * * * \\
(-6.12)\end{array}$ & $\begin{array}{c}-.3255^{* * * *} \\
(-6.12)\end{array}$ & $\begin{array}{c}-.3255 * * * \\
(-6.12)\end{array}$ & $\begin{array}{c}-.3255^{* * * *} \\
(-6.11)\end{array}$ & $\begin{array}{c}-.3255 * * * \\
(-6.11)\end{array}$ \\
\hline INDEX_MEMBER & & $\begin{array}{c}2628 * * * \\
(5.65)\end{array}$ & $\begin{array}{c}.2638 * * * \\
(5.68)\end{array}$ & $\begin{array}{c}.2637 * * * \\
(5.68)\end{array}$ & $\begin{array}{c}2640 * * * \\
(5.70)\end{array}$ & $\begin{array}{c}2639 * * * \\
(5.68)\end{array}$ & $\begin{array}{c}.2641 * * * \\
(5.69)\end{array}$ \\
\hline Year fixed effects & & Yes & Yes & Yes & Yes & Yes & Yes \\
\hline Industry fixed effects & & Yes & Yes & Yes & Yes & Yes & Yes \\
\hline Clustered (firm) & & Yes & Yes & Yes & Yes & Yes & Yes \\
\hline Adj. $\mathrm{R}^{2}$ & & 0.3162 & 0.3207 & 0.3204 & 0.3201 & 0.3201 & 0.3197 \\
\hline Sample Size & & 2086 & 2086 & 2086 & 2086 & 2086 & 2086 \\
\hline
\end{tabular}

Panel B. Basic model separately for a UK \& GER sample

\begin{tabular}{|c|c|c|c|c|c|c|c|}
\hline \multirow{3}{*}{ Independent Variables } & \multirow{3}{*}{$\begin{array}{l}\text { Pred. } \\
\text { Sign }\end{array}$} & \multicolumn{6}{|c|}{$\begin{array}{c}\text { Firm Value Measure: Tobin's Q (dependent variable) } \\
\end{array}$} \\
\hline & & \multicolumn{3}{|c|}{ UK Sample (M1-M3) } & \multicolumn{3}{|c|}{ GER Sample (M4-M6) } \\
\hline & & Model 1 & Model 2 & Model 3 & Model 4 & Model 5 & Model 6 \\
\hline Intercept & & $\begin{array}{c}2.7872 * * * \\
(9.07)\end{array}$ & $\begin{array}{c}2.8682^{* * * *} \\
(9.34)\end{array}$ & $\begin{array}{c}2.8666^{* * *} \\
(9.33)\end{array}$ & $\begin{array}{l}.4911 \\
(1.13) \\
\end{array}$ & $\begin{array}{l}.5025 \\
(1.18) \\
\end{array}$ & $\begin{array}{l}.4761 \\
(1.10) \\
\end{array}$ \\
\hline CGQ & + & $\begin{array}{c}.0013 * * * \\
(2.97)\end{array}$ & & & $\begin{array}{l}.0009 \\
(1.41)\end{array}$ & & \\
\hline CGI & + & & $\begin{array}{c}.0019 * * * \\
(4.20)\end{array}$ & $\begin{array}{c}.0019 * * * * \\
(4.19)\end{array}$ & & $\begin{array}{l}.0015^{* *} \\
(2.35)\end{array}$ & $\begin{array}{l}.0015^{* * *} \\
(2.30)\end{array}$ \\
\hline TECHNOLOGY & + & & & $\begin{array}{l}-.0001 \\
(-0.17)\end{array}$ & & & $\begin{array}{l}-.0006 \\
(-0.69) \\
\end{array}$ \\
\hline SIZE & & $\begin{array}{c}-.1247 * * * \\
(-8.31)\end{array}$ & $\begin{array}{c}-.1291 * * * \\
(-8.59)\end{array}$ & $\begin{array}{c}-.1290 * * * \\
(-8.58)\end{array}$ & $\begin{array}{l}-.0186 \\
(-0.95)\end{array}$ & $\begin{array}{l}-.0197 \\
(-1.03)\end{array}$ & $\begin{array}{l}-.0186 \\
(-0.97)\end{array}$ \\
\hline LEVERAGE & & $\begin{array}{c}.1925 * * \\
(2.03)\end{array}$ & $\begin{array}{c}.1913^{* *} \\
(2.02)\end{array}$ & $\begin{array}{c}.1914 * * \\
(2.02)\end{array}$ & $\begin{array}{c}-.5266 * * * \\
(-2.77)\end{array}$ & $\begin{array}{c}-.5156 * * * \\
(-2.76)\end{array}$ & $\begin{array}{c}-.5119 * * * \\
(-2.75)\end{array}$ \\
\hline GROWTH & & $\begin{array}{l}.0104 \\
(1.22)\end{array}$ & $\begin{array}{l}.0102 \\
(1.25)\end{array}$ & $\begin{array}{l}.0102 \\
(1.25)\end{array}$ & $\begin{array}{l}.1824^{*} \\
(1.91)\end{array}$ & $\begin{array}{l}.1750^{*} \\
(1.87)\end{array}$ & $\begin{array}{l}.1800^{*} \\
(1.90)\end{array}$ \\
\hline FREEFLOAT & & $\begin{array}{l}.0020^{*} \\
(1.86)\end{array}$ & $\begin{array}{l}.0018^{*} \\
(1.75)\end{array}$ & $\begin{array}{l}.0018^{*} \\
(1.75)\end{array}$ & $\begin{array}{c}-.0024 * * \\
(-2.27)\end{array}$ & $\begin{array}{c}-.0025 * * \\
(-2.37)\end{array}$ & $\begin{array}{c}-.0025 * * \\
(-2.37)\end{array}$ \\
\hline CAPITAL_INTENSITY & & $\begin{array}{c}-.3125^{* * *} \\
(-5.55)\end{array}$ & $\begin{array}{c}-.3154 * * * \\
(-5.64)\end{array}$ & $\begin{array}{c}-.3155^{* * *} \\
(-5.64)\end{array}$ & $\begin{array}{l}-.3205^{*} \\
(-1.71)\end{array}$ & $\begin{array}{l}-.3304^{*} \\
(-1.81)\end{array}$ & $\begin{array}{l}-.3322^{*} \\
(-1.82)\end{array}$ \\
\hline INDEX_MEMBER & & $\begin{array}{c}.3192 * * * \\
(6.24)\end{array}$ & $\begin{array}{c}.3203 * * * \\
(6.28)\end{array}$ & $\begin{array}{c}.3201 * * * \\
(6.28)\end{array}$ & $\begin{array}{l}.0719 \\
(0.79) \\
\end{array}$ & $\begin{array}{l}.0740 \\
(0.81) \\
\end{array}$ & $\begin{array}{l}.0783 \\
(0.86)\end{array}$ \\
\hline Year fixed effects & & Yes & Yes & Yes & Yes & Yes & Yes \\
\hline Industry fixed effects & & Yes & Yes & Yes & Yes & Yes & Yes \\
\hline Clustered (firm) & & Yes & Yes & Yes & Yes & Yes & Yes \\
\hline Adj. $\mathrm{R}^{2}$ & & 0.3180 & 0.3235 & 0.3231 & 0.3699 & 0.3773 & 0.3765 \\
\hline Sample Size & & 1677 & 1677 & 1677 & 409 & 409 & 409 \\
\hline
\end{tabular}


level and is used in log form), CGQ / CGI stands for the employed governance rating, and CONTROL is a set of control variables (Size is log of total assets, Leverage is total debt to total assets, Growth is 3 years average growth in net sales, free float is number of shares as free float to total shares outstanding, Capital-Intensity is PPE to total assets, Index Membership indicates blue chip firms based on FTSE100 for UK firms and DAX30 for GER firms, UK dummy indicates UK firms). TECHNOLOGY as the residuals from cross sectional OLS regressions with the following format: $\mathrm{CGQ}_{\mathrm{i}}=\alpha+\beta \mathrm{CGI}_{\mathrm{i}}+\varepsilon$ represents the incremental usefulness of the CGQ (through superior weighting technology and / or private information) relative to our naïve CGI rating. UK $\times$ CGI and UK $\times$ TECHNOLOGY are interaction terms between the UK dummy variable and the CGI score, as well as the UK dummy variable and the TECHNOLOGY score, respectively. The regression models contain year- and industry-fixed effects (based on first-digit SIC industry codes), and have standard errors which are heteroskedasticity robust (White, 1980) and one-way clustered at firm level (Gow et al., 2010; Petersen, 2009). Reported values: coefficient (t-stat). ${ }^{* *}(* *)(*)$ indicates significance at 1\% (5\%) (10\%), two-tailed level.

\subsubsection{Discussion}

\section{Commercial governance ratings and firm value}

Consistent with our first prediction, our results document that high (commercial) CG ratings on average imply higher corporate valuations. This is consistent with recent findings for Europe (e.g., Renders et al., 2010) and for the U.S. (Spellman and Watson, 2009). However, as outlined in section 3.2.2, some prior studies for Europe (Bauer et al., 2004) and the U.S. (e.g., Daines et al., 2010) present mixed or even insignificant results on this relationship.

One explanation for these mixed results rests on the comparatively higher compliance rates for U.S. as opposed to UK and German firms with respect to the underlying governance criteria. Renders et al. (2010) note that stricter governance regulation increases compliance levels for all sample firms, and mechanically reduces sample variation for governance quality. Because our descriptive analysis reveals a rather low compliance rate of 30.9\% (23\%) in 2003 for the UK sample (German sample), we can rule out that such an effect affects our regression results. In addition, stickiness of firm-level governance ratings, especially in panel data settings, weakens the robustness of the U.S. findings, because again, variation in the explanatory variable is lost, and with it, statistical power (Brown et al., 2011). Our findings, however, are not subject to this concern, given the low serial correlation of our governance ratings across both samples, documented in Panel E of Table 3 - 5.

Another potential explanation for the contrasting results of prior studies is the respective time frame chosen. The three most recent U.S. studies, for example, which find mixed or even insignificant results (Epps and Cereola, 2008; Daines et al., 2010; Ertugrul and Hegde, 2009), examine commercially available CG ratings for different time frames between 2002 and 2006, a period of rising stock markets. Mitton (2002) provides empirical evidence that governance quality may play a stronger role for investment decisions of investors in times of economic 
downturn, because investors are inclined to ignore weaknesses in the governance structure of firms during times of prosperity. Our results do not support the notion of such an asymmetry in the underlying governance-valuation relationship, as we find positive associations for a period of on average rising stock markets, 2003 to $2007 .^{61}$

\section{Incremental usefulness of commercial rating technology}

With respect to our second prediction, our results shed light on the question whether or how commercially available CG ratings are potentially valuable for investors. Despite the overall positive relationship between the commercial $\mathrm{CG}$ rating and firm valuation, our findings suggest that in our setting, rating vendors do not create incremental value in the process of weighting and constructing their ratings and/or due to the vendor's access to non-public information. In all specifications of our analyses, the CGQ rating was not able to provide additional explanatory power relative to our naïve CGI rating as the coefficient estimate on TECHNOLOGY remained insignificant. Consistent with this, over all specifications, our naïve rating outperforms the commercial rating in terms of statistical significance. Thus, contrary to our second prediction, our naïve CGI rating, which is based on the same publicly available governance data as the CGQ rating, does not appear to be less accurate in picturing the governance structure of firms. Our results are robust, as our research design uses each firm as its own control and therefore controls for sample characteristics like the exceptional time frame, sample composition, or data quality. Moreover, and contrary to our third prediction, the fact that our findings hold for both the UK and the German sample leads us to rule out the possibility that our results are driven by a shareholder-based approach to governance quality adopted by the rating agency.

Given the economic role of commercial governance ratings outlined in section 3.3.2, our findings lend themselves to at least three, non-exclusive explanations. First, assuming that the existence of rating agencies signifies their economic importance, our finding that no incremental value is created in the process of constructing and incrementally enhancing the rating suggests that the agency's main competitive advantage may rather lie in its activities of

\footnotetext{
${ }^{61}$ However, we cannot ultimately rule out such an effect. We re-run our analyses with a restricted sample that excludes all firm observations for the year 2003, which witnessed the most vigorous stock market surge, and find similar results. However, the significance levels for the CGQ and the CGI rating improve considerably, as coefficients now show t-values around 3 (in case of CGQ) and around 4 (in case of CGI) in the models across all three different sample compositions.
} 
efficiently collecting publicly available information on firms' governance characteristics. Accordingly, the value created by rating agencies would be reflected by their competitive cost advantage in identifying and collecting information from financial reports and other publicly available sources. This would result in transaction cost savings for institutions that purchase the rating vendors' products. Such an explanation receives support from interviews with institutional investors that Daines et al. (2010) report. Their interpretation with respect to the question why investors buy commercial CG ratings is that "purchasing the ratings is a costeffective way to obtain the underlying data." (Daines et al., 2010, p. 461, footnote 34).

Our second explanation, in contrast, defies the economic vindication of governance ratings as commercial products, as they do not create value for investors. This would be a rather troublesome result, questioning both investor rationality as well as the expertise of rating agencies. Therefore, a third explanation is that our economic model does not fully capture the potential usefulness of investor ratings. For instance, investors may not only use the rating for purposes of firm valuation, but also in their proxy voting activities. Also, these ratings may play a role in investment managers' vindication of their investment decisions, or may even be required for that purpose as they are deemed to reflect objective outside expertise. In any event, our findings suggest that these other potential factors deserve increased attention.

Finally, we need to caution that our findings are subject to several limitations, which are inherent in our dataset. For instance, the results we document using the CGQ rating do not necessarily translate to other commercially available CG ratings. The findings of Daines et al. (2010) emphasize this point, as they reveal relatively low correlations among three commercial CG ratings (GMI, CGQ, TCL ratings) for the U.S. market. It may well be that different players in that market create value in different ways. Put differently, while ISS may mainly create value through its process of information gathering, other firms may be more adept at aggregating and weighting publicly available information, or infusing private knowledge into the ratings. Concerns relating to the statistical robustness of our results are addressed in the following sections, where we re-run our analyses by controlling simultaneously for endogeneity as well as sample selection and assess the robustness of our main regression findings in more detail. 


\subsubsection{Endogeneity and Sample Selectivity}

Prior literature emphasizes the need to control for endogeneity of firm level governance quality (e.g., Bhagat and Bolton, 2008). In addition, in European or German settings with on average smaller samples compared to U.S. studies, the results are potentially prone to sample selectivity (e.g., Boersch-Supan and Koeke, 2002). To address both problems, we follow Renders et al. (2010), who apply a three-stage model that controls simultaneously for sample selectivity and endogeneity (Mroz, 1987). The first level of the model (Heckman regression) addresses the sample selection bias. The selection regression models the rating vendors' selection process and adjusts the third-stage and the IV regression for the selection effect, including the inverse Mills ratio. We use pension funds holding and dividend per shares as exclusion restrictions of the selection model. ${ }^{62}$ The second level of the model (IV regression) controls for endogeneity by regressing the endogenous governance variable on the instrument variable (IV) and on all control variables (including the inverse Mills ratio). This yields predicted variables for the governance variables, which replace the original endogenous ones in the third-stage regression. Following prior literature, we use one-year lagged governance ratings (Renders et al., 2010) and industry-median governance ratings (Aggarwal et al., 2009; Jiraporn et al., 2011/2012) as our instruments. ${ }^{63}$ Finally, the third-stage regression includes

\footnotetext{
${ }^{62}$ Although the choice of exclusion restrictions is crucial for the validity of selection, Lennox et al. (2010, p. $590,592)$ note that a "surprising number of studies fail to have any exclusions, and other studies do not report the first stage model, making it impossible to determine if they imposed exclusion restrictions." In the absence of prior research providing exclusion restrictions for the selection process of rating vendors, we use pension funds holding and dividends per share as our criteria. We conjecture that firms with high dividends and a high degree of pension funds holding are more likely covered by ISS. For one reason, institutional investors hire and pay governance analysts to provide governance ratings. Nevertheless, from a theoretical perspective, we are not able to rule out that our exclusion restrictions are unrelated to both the firm's governance quality and its valuation. It is plausible to assume that governance choices might affect shareholders' investment behavior and that dividends might reflect value relevant cash flow streams. Auxiliary regressions (Tobin's Q / governance quality on both instruments and additional controls), however, support the choice of our exclusion restrictions. They suggest that dividends and pension funds holdings are uncorrelated to firm value and governance choices. In addition, splitting the three-stage model (Heckman and IV regressions separately, see Appendix 3 - 2) or following the approach proposed by Aggarwal et al. (2009, pp. 3164-3165) and using a probit regression (CGQ selection on total asset and number of employees) as an alternative first stage regression do not alter our inferences.

${ }^{63}$ The standard text book solution is to include instruments into the estimation equation. This method is appropriate as long as the instrument variables are correlated with the endogenous regressor, but uncorrelated with the error term in the estimation model. However, in most empirical setups it is difficult to find appropriate instruments (e.g., Larcker and Rusticus, 2010). In the absence of a 'perfect' instrument, we use two different instruments which are motivated by prior literature: one-year lagged governance ratings (e.g., Renders et al., 2010) as well as industry-median governance ratings (e.g., Jiraporn et al., 2011). The former instrument is a socalled semi-endogenous instrument correlating with both the endogenous variable and the error term. As our semi-endogenous instrument meets both criteria proposed by Larcker and Rusticus (2010, p. 191), i.e., (i) a reasonably high correlation with the endogenous variable (Table 3 - 7) and (ii) a potentially lower degree of endogeneity as the original endogenous variable, the corresponding 2SLS regression is preferable to OLS. In contrast to lagged governance ratings, the industry-median governance ratings are a so-called weak instrument. It is most likely exogenous (uncorrelated to the error term) but only weakly correlated with the endogenous
} 
the inverse Mills ratio from the selection regression and the predicted governance rating from the IV regression as additional explanatory variables.

Table 3 - 7: First Stages (Selection) \& Second Stages (Endogeneity)

\begin{tabular}{|c|c|c|c|c|c|c|}
\hline \multirow{3}{*}{ Variables } & \multicolumn{2}{|c|}{ First Stages (M1-M2) } & \multicolumn{4}{|c|}{ Second Stages (M3-M6) ${ }^{64}$} \\
\hline & Model 1 & Model 2 & Model 3 & Model 4 & Model 5 & Model 6 \\
\hline & $\operatorname{Probit}\left(C G Q_{U K}\right)$ & $\operatorname{Probit}\left(C G Q_{G E R}\right)$ & $C G Q_{U K}$ & $C G I_{U K}$ & $C G Q_{G E R}$ & $C G I_{G E R}$ \\
\hline \multirow[t]{2}{*}{ Intercept } & $-17.20 * * *$ & $-12.50 * * *$ & 11.132 & -15.10 & -56.37 & $-124.84 * *$ \\
\hline & $(-16.35)$ & $(-8.35)$ & $(0.59)$ & $(-0.78)$ & $(-1.04)$ & $(-2.35)$ \\
\hline \multirow[t]{2}{*}{ SIZE } & $.7791 * * *$ & $.5591 * * *$ & -.0593 & 1.0903 & 3.1437 & $5.6102 * * *$ \\
\hline & $(14.54)$ & $(8.42)$ & $(-0.07)$ & $(1.28)$ & $(1.47)$ & $(2.62)$ \\
\hline \multirow[t]{2}{*}{ LEVERAGE } & $-.4373 *$ & $-.9184 * *$ & 3.296 & -.0595 & 8.3485 & -3.0949 \\
\hline & $(-1.83)$ & $(-2.43)$ & $(0.95)$ & $(-0.02)$ & $(0.81)$ & $(-0.30)$ \\
\hline \multirow[t]{2}{*}{ GROWTH } & -.0414 & $-.1890 * *$ & -.3077 & -.1353 & $8.1470 * * *$ & $5.3146^{*}$ \\
\hline & $(-1.18)$ & $(-2.11)$ & $(-1.29)$ & $(-0.29)$ & $(2.81)$ & $(1.74)$ \\
\hline \multirow[t]{2}{*}{ FREEFLOAT } & $.0040 * *$ & $.0056^{* *}$ & $.1476 * * *$ & $.1478 * * *$ & -.02052 & .0276 \\
\hline & $(2.07)$ & $(2.57)$ & $(3.15)$ & $(3.33)$ & $(-0.33)$ & $(0.44)$ \\
\hline CAPITAL_ & $-.2344 *$ & $-1.1941 * *$ & 1.6197 & 1.5858 & 6.4305 & 3.8395 \\
\hline INTENSITY & $(-1.65)$ & $(-2.29)$ & $(0.59)$ & $(0.61)$ & $(0.65)$ & $(0.31)$ \\
\hline INDEX_ & -.2815 & $1.3498 * *$ & .7708 & -.1325 & 6.2110 & 1.3690 \\
\hline MEMBĒR & $(-1.23)$ & $(2.00)$ & $(0.34)$ & $(-0.06)$ & $(1.24)$ & $(0.29)$ \\
\hline \multirow[t]{2}{*}{ TECHNOLOGY } & & & & $-.1124 * * *$ & & $-.1866^{* *}$ \\
\hline & & & & $(-3.18)$ & & $(-2.50)$ \\
\hline \multirow[t]{2}{*}{ Pension Funds } & $.0249 * *$ & $.0918 * * *$ & & & & \\
\hline & $(2.34)$ & $(3.07)$ & & & & \\
\hline \multirow[t]{2}{*}{ DPS } & $.0261 * *$ & $-.0757 * *$ & & & & \\
\hline & $(2.56)$ & $(-2.06)$ & & & & \\
\hline Inverse Mills & & & $-8.5504 * * *$ & $-6.1881 * *$ & -2.8128 & 2.1272 \\
\hline Ratio & & & $(-3.36)$ & $(-2.47)$ & $(-0.51)$ & $(0.39)$ \\
\hline \multirow[t]{2}{*}{ Lag_CGQ } & & & $.3978 * * *$ & & $.1952 * * *$ & \\
\hline & & & $(12.85)$ & & $(4.00)$ & \\
\hline \multirow[t]{2}{*}{ Ind-Median_CGQ } & & & $.3345 * * *$ & & $.5729 * * *$ & \\
\hline & & & $(4.87)$ & & $(4.32)$ & \\
\hline \multirow[t]{2}{*}{ Lag_CGI } & & & & $.4335 * * *$ & & $.2485 * * *$ \\
\hline & & & & $(14.95)$ & & $(4.39)$ \\
\hline \multirow[t]{2}{*}{ Ind-Median_CGI } & & & & $.3029 * * *$ & & $.6713 * * *$ \\
\hline & & & & $(4.34)$ & & $(5.35)$ \\
\hline Year fe & Yes & Yes & Yes & Yes & Yes & Yes \\
\hline Industry fe & Yes & Yes & Yes & Yes & Yes & Yes \\
\hline Cluster (firm) & Yes & Yes & Yes & Yes & Yes & Yes \\
\hline Pseudo $\mathrm{R}^{2}$ & .5691 & .5204 & & & & \\
\hline Centered $\mathrm{R}^{2}$ & & & .3217 & 3719 & .3394 & 2957 \\
\hline Sample Size & 5919 & 2858 & 1182 & 1182 & 314 & 314 \\
\hline F-Test & - & - & 38.26 & 45.43 & 16.76 & 13.64 \\
\hline \multicolumn{7}{|c|}{ Stock-Yogo weak ID test $(10 \%=19.93 / 15 \%=11.59)$} \\
\hline - Kleiber & n-Paap rk Wal & F statistic & 130.78 & 140.32 & 26.77 & 45.44 \\
\hline Sargan-Han & n test ( $p$-value & & 0.2571 & 0.1000 & 0.7357 & 0.7282 \\
\hline
\end{tabular}

Notes: The underlying regression model for the selection process is: Probit(Sample $)_{i t}=\alpha+\sum \beta$ CONTROL $_{i t}+$ $\sum \gamma E X C L U_{i t}+\sum \delta Y E A R_{i t}+\sum \varphi I N D_{i t}+\varepsilon$, where $\alpha$ represents the constant term, $\beta, \gamma, \delta$, and $\varphi$ are the coefficients

variable (e.g., Renders et al., 2010, p. 92; Jiraporn et al., 2011, p. 266). Nevertheless, the choice of both instruments is supported by F-stats of the IV regressions, the Stock and Yogo (2005) test statistic for weak instruments, the Durbin-Wu-Hausman test for endogeneity, and the Hansen's J statistic for over-identification (see Table 3 - 8).

${ }^{64}$ With respect to all specifications of the Third-Stage regressions provided in Table 3 - 8, we report - for the sake of brevity - only four second stage regressions in Table 3 - 7. 
of the explanatory variables, $\varepsilon$ is the error term. The selected sample consists of all UK and/or GER firms which received a governance rating by ISS (sample of the study). The UK and / or GER Worldscope Universe serves as the basic population for the selection process. Thus, the Probit(Sample) variable is one if the company received a rating score or zero otherwise. CONTROL is a set of control variables (size is log of total assets, leverage is total debt to total assets, growth is 3 years average growth in net sales, free float is number of shares as free float to total shares outstanding, capital-intensity is PPE to total assets, index membership indicates blue chip firms based on FTSE100 for UK firms and DAX30 for GER firms). EXCLU is a set of exclusion restrictions (Pension Funds is shares held by pension funds to total shares outstanding; DPS as dividend per share). The underlying regression model for the IV regression is: $G O V_{i t}=\alpha+\beta I V_{i t}+\sum \gamma C O N T R O L_{i t}+$ $\delta M_{L L L S}+\sum \varphi Y E A R_{i t}+\sum \omega I N D_{i t}+\varepsilon$, where $\alpha$ represents the constant term, $\beta, \gamma, \delta, \varphi$, and $\omega$ are the coefficients of the explanatory variables, $\varepsilon$ is the error term. GOV is the employed governance rating (either CGQ or CGI). IV is either one-year lag of CGQ and industry-median CGQ or one-year lag of CGI and industrymedian CGI as the instrument variables. The IV choice is supported by fairly high Stock and Yogo (2005) test statistics and the F-test of the reduced form regression. MILLS is the inverse mills ratio from the selection regression. The regression models contain year- and industry-fixed effects (based on first-digit SIC industry codes), and have standard errors which are heteroskedasticity robust (White, 1980) and one-way clustered at firm level (Gow et al., 2010; Petersen, 2009). Stock-Yogo test based on the Kleibergen-Paap rk Wald F statistic (instead of Cragg-Donald Wald F statistic due to clustered standard errors; see Baum et al., 2007) rejects the null hypothesis of weak instruments for both ratings in both country samples. The Sargan-Hansen test statistic (respectively the Hansen's J statistic due to clustered se) is an over-identification test of all instruments (p-values reported). Test Reported values: coefficient (t-statistics). *** $(* *)(*)$ indicates significance at 1\% $(5 \%)(10 \%)$, two-tailed level.

Table 3 - 7 reports the results of the first (selection) and the second (endogeneity) stages of the three-stage model separately for the UK and German sample. Compared to Renders et al. (2010), who report a pseudo $\mathrm{R}^{2}$ of $75 \%$, the pseudo $\mathrm{R}^{2}$ for our first stages reveal that our selection equation models the selection process on a rather moderate level, with a pseudo $\mathrm{R}^{2}$ ranging between 52 and $57 \%$. This possibly indicates that our sample is already diversified to some extent. Nevertheless, we observe that firms with higher total assets, lower leverage, higher free float, lower capital-intensity, higher dividend per shares, and higher pension funds holdings are more likely to be included into our final samples. The IV regressions model the endogeneity problem. Our instrument variables are highly significant for all four models. The F-test statistics across the models are fairly high (in all cases above the threshold of 10) and the instrument variables pass the Stock and Yogo (2005) test for weak instruments (at a 10\% level) and the Sargan-Hansen test for over-identification. This suggests that the instruments are effective.

Table 3 - 8 reports the results of the third stage regressions across the three different sample compositions. The signs and the significance levels of our control variables do not differ qualitatively from the basic OLS models. The Durbin-Wu-Hausman (DWH) augmented regression test suggested by Davidson and MacKinnon (1993) reveals that both governance 
ratings are endogenous across the three samples. ${ }^{65}$ Our variable capturing the value generated through the rating process (TECHNOLOGY), however, appears to be exogenous. Complementing the DWH test, the significant coefficients of the inverse Mills ratio (Mills) in the combined sample and the UK sample (Table 3 - 8, Panels A and B) indicate that the respective OLS regressions possibly suffer from a sample selection bias.

Table 3 - 8: Regression Results - Third Stage of the Three Stage Model

\begin{tabular}{|c|c|c|c|c|c|c|c|c|c|c|}
\hline \multirow{3}{*}{$\begin{array}{l}\text { Independ. } \\
\text { Variables }\end{array}$} & \multirow{3}{*}{$\begin{array}{l}\text { Pred. } \\
\text { Sign }\end{array}$} & \multicolumn{9}{|c|}{$\begin{array}{c}\text { Firm Value Measure: Tobin's Q (dependent variable) } \\
\end{array}$} \\
\hline & & \multicolumn{3}{|c|}{ UK \& GER Sample (M1-M3) } & \multicolumn{3}{|c|}{ UK Sample (M4-M6) } & \multicolumn{3}{|c|}{ GER Sample (M7-M9) } \\
\hline & & Model 1 & Model 2 & Model 3 & Model 4 & Model 5 & Model 6 & Model 7 & Model 8 & Model 9 \\
\hline Intercept & & $\begin{array}{c}1.398 * * * \\
(3.18)\end{array}$ & $\begin{array}{c}1.502^{* * * *} \\
(3.33)\end{array}$ & $\begin{array}{c}1.429 * * * \\
(3.23)\end{array}$ & $\begin{array}{c}1.258^{* * * *} \\
(3.04)\end{array}$ & $\begin{array}{c}1.368^{* * * *} \\
(3.26)\end{array}$ & $\begin{array}{c}1.295 * * * \\
(3.13)\end{array}$ & $\begin{array}{l}1.210^{*} \\
(1.66)\end{array}$ & $\begin{array}{l}1.451^{*} \\
(1.78)\end{array}$ & $\begin{array}{l}1.345^{*} \\
(1.69)\end{array}$ \\
\hline $\mathbf{C G Q}_{\text {pred }}$ & + & $\begin{array}{c}.003 * * * \\
(3.27)\end{array}$ & & & $\begin{array}{c}.003 * * * \\
(2.68)\end{array}$ & & & $\begin{array}{c}.005 * * * \\
(2.73)\end{array}$ & & \\
\hline CGI $_{\text {pred }}$ & + & & $\begin{array}{c}.004 * * * * \\
(4.24)\end{array}$ & & & $\begin{array}{c}.004 * * * \\
(3.88)\end{array}$ & & & $\begin{array}{c}.006^{* * * *} \\
(3.67)\end{array}$ & \\
\hline $\mathbf{R S}_{\text {pred }}$ & + & & & $\begin{array}{c}.002 \\
(0.95)\end{array}$ & & & $\begin{array}{c}.001 \\
(\mathbf{0 . 6 1 )}\end{array}$ & & & $\begin{array}{c}-.000 \\
(-0.07)\end{array}$ \\
\hline CGI & + & & & $\begin{array}{c}.002 * * * * \\
(5.15)\end{array}$ & & & $\begin{array}{c}.002^{* * * *} \\
(4.20)\end{array}$ & & & $\begin{array}{c}.003 * * * \\
(3.90)\end{array}$ \\
\hline RS & + & & $\begin{array}{c}.001 \\
(1.19)\end{array}$ & & & $\begin{array}{c}.001 \\
(\mathbf{0 . 8 0}) \\
\end{array}$ & & & $\begin{array}{c}.001 \\
(1.09) \\
\end{array}$ & \\
\hline UK & & $\begin{array}{c}.192^{* * * *} \\
(2.94)\end{array}$ & $\begin{array}{c}.185^{* * *} \\
(2.80)\end{array}$ & $\begin{array}{c}.194^{* * * *} \\
(2.95)\end{array}$ & & & & & & \\
\hline SIZE & & $\begin{array}{c}-.067 * * * * \\
(-4.05)\end{array}$ & $\begin{array}{c}-.072 * * * * \\
(-4.28)\end{array}$ & $\begin{array}{c}-.065 * * * \\
(-4.03)\end{array}$ & $\begin{array}{c}-.061 * * * \\
(-3.60)\end{array}$ & $\begin{array}{c}-.068^{* * *} \\
(-3.97)\end{array}$ & $\begin{array}{c}-.060 * * * \\
(-3.63)\end{array}$ & $\begin{array}{c}-.046 \\
(-1.53)\end{array}$ & $\begin{array}{l}-.056^{*} \\
(-1.69)\end{array}$ & $\begin{array}{c}-.045 \\
(-1.39)\end{array}$ \\
\hline LEVERAGE & & $\begin{array}{c}.098 \\
(1.04)\end{array}$ & $\begin{array}{c}.101 \\
(1.06)\end{array}$ & $\begin{array}{c}.102 \\
(1.09)\end{array}$ & $\begin{array}{l}.226^{* *} \\
(2.34)\end{array}$ & $\begin{array}{l}.222 * * \\
(2.28)\end{array}$ & $\begin{array}{l}.227 * * \\
(2.34)\end{array}$ & $\begin{array}{c}-.584 * * * \\
(-3.00)\end{array}$ & $\begin{array}{c}-.511 * * * \\
(-2.78)\end{array}$ & $\begin{array}{c}-.519^{* *} \\
(-2.59)\end{array}$ \\
\hline GROWTH & & $\begin{array}{c}.007 \\
(0.78)\end{array}$ & $\begin{array}{c}.007 \\
(0.78)\end{array}$ & $\begin{array}{c}.007 \\
(0.77)\end{array}$ & $\begin{array}{l}-.003 \\
(-0.39)\end{array}$ & $\begin{array}{l}-.003 \\
(-0.42)\end{array}$ & $\begin{array}{l}-.003 \\
(-0.46)\end{array}$ & $\begin{array}{l}.167 \\
(1.34)\end{array}$ & $\begin{array}{c}.152 \\
(1.34)\end{array}$ & $\begin{array}{l}.215^{*} \\
(1.78)\end{array}$ \\
\hline FREEFLOAT & & $\begin{array}{l}-.000 \\
(-0.44)\end{array}$ & $\begin{array}{l}-.001 \\
(-0.67)\end{array}$ & $\begin{array}{l}-.000 \\
(-0.32)\end{array}$ & $\begin{array}{l}.002^{*} \\
(1.71)\end{array}$ & $\begin{array}{c}.002 \\
(1.38)\end{array}$ & $\begin{array}{l}.002^{*} \\
(1.82)\end{array}$ & $\begin{array}{c}-.003 * * * \\
(-3.12)\end{array}$ & $\begin{array}{c}-.004 * * * \\
(-3.18)\end{array}$ & $\begin{array}{c}-.003 * * * \\
(-3.06)\end{array}$ \\
\hline $\begin{array}{l}\text { CAPITAL } \\
\text { INTENSITY }\end{array}$ & & $\begin{array}{c}-317 * * * \\
(-5.78)\end{array}$ & $\begin{array}{c}-.324 * * * \\
(-5.93)\end{array}$ & $\begin{array}{c}-317 * * * \\
(-5.81)\end{array}$ & $\begin{array}{c}-.321 * * * \\
(-5.57)\end{array}$ & $\begin{array}{c}-.319 * * * \\
(-5.68)\end{array}$ & $\begin{array}{c}-314 * * * \\
(-5.61)\end{array}$ & $\begin{array}{c}-.318 \\
(-1.58)\end{array}$ & $\begin{array}{l}-.304^{*} \\
(-1.70)\end{array}$ & $\begin{array}{c}-.294 \\
(-1.53)\end{array}$ \\
\hline INDEX_ & & $.229^{* * *}$ & $.233^{* * *}$ & $229^{* * *}$ & $240^{* * *}$ & $242 * * *$ & .239 & .005 & .021 & .045 \\
\hline MEMBER & & $(4.97)$ & $(5.07)$ & $(5.03)$ & $(5.14)$ & $(5.21)$ & $(5.15)$ & $(0.06)$ & $(0.26)$ & $(0.56)$ \\
\hline INVERSE_ & & $.177 * *$ & $.175^{* *}$ & $.169^{* *}$ & $.294 * * *$ & $.303^{* * *}$ & $.289^{* * *}$ & -.047 & -.070 & -.082 \\
\hline MILLS & & $(2.43)$ & $(2.40)$ & $(2.29)$ & $(3.59)$ & $(3.67)$ & $(3.52)$ & $(-0.52)$ & $(-0.73)$ & $(-0.84)$ \\
\hline Year fe & & Yes & Yes & Yes & Yes & Yes & Yes & Yes & Yes & Yes \\
\hline Industry fe & & Yes & Yes & Yes & Yes & Yes & Yes & Yes & Yes & Yes \\
\hline Cluster (firm) & & Yes & Yes & Yes & Yes & Yes & Yes & Yes & Yes & Yes \\
\hline Centered $\mathrm{R}^{2}$ & & .3339 & .3340 & .3437 & .3544 & .3508 & .3623 & .4327 & .4188 & .4707 \\
\hline Sample Size & & 1496 & 1496 & 1496 & 1182 & 1182 & 1182 & 314 & 314 & 314 \\
\hline DWH test & & $(-2.03)^{* *}$ & $(-2.9)^{* * *}$ & $(0.35)$ & $(-1.81)^{*}$ & $(-2.8)^{* * *}$ & $(0.17)$ & $(-1.67)^{*}$ & $(-2.8)^{* * *}$ & $(0.58)$ \\
\hline F test (second sta & tage) & 37.17 & 42.63 & 9.71 & 38.26 & 45.43 & 9.98 & 16.76 & 13.64 & 9.00 \\
\hline Kleibergen-Paap & $\mathrm{pF}$ & 134.84 & 171.85 & 71.26 & 130.78 & 140.32 & 74.19 & 26.77 & 45.44 & 11.24 \\
\hline Sargan-Hansen te & test & 0.4402 & 0.1123 & 0.0962 & 0.2571 & 0.1000 & 0.2149 & 0.7357 & 0.7282 & 0.7157 \\
\hline
\end{tabular}

Notes: The underlying regression models for the third stage regressions are: $Q_{i t}=\alpha+\beta_{1} G O V p r e d_{i t}+\beta_{2} M_{L I L L S}$ $+\sum \gamma$ CONTROL $_{i t}+\sum \delta$ YEAR $_{i t}+\sum \varphi I_{N} D_{i t}+\varepsilon, Q_{i t}=\alpha+\beta_{1}$ CGIpred $_{i t}+\beta_{2}$ TECHNOLOGY $i t+\beta_{3}$ MILLS $_{i t}$ $+\sum \gamma$ CONTROL $_{i t}+\sum \delta Y E A R_{i t}+\sum \varphi I_{i t}+\varepsilon$, and $Q_{i t}=\alpha+\beta_{1}$ CGI $_{i t}+\beta_{2}$ TECHNOLOGYpred ${ }_{i t}+\beta_{3}$ MILLS $_{i t}$ $+\sum \gamma$ CONTROL $_{i t}+\sum \delta Y E A R_{i t}+\sum \varphi I N D_{i t}+\varepsilon$, , where $\alpha$ represents the constant term, $\beta, \gamma, \delta, \varphi$, and $\omega$ are the

${ }^{65}$ The Durbin-Wu-Hausman augmented regression test suggested by Davidson and MacKinnon (1993) is performed by obtaining the residuals from the model of the endogenous (governance rating) right-hand side variable as a function of all exogenous variables, and including these residuals in a regression of the original model. If the coefficient of the included residuals is different from zero, the OLS estimates are not consistent due to endogeneity of the assumed endogenous (governance rating) variable (De Fraja et al., 2010, pp. 581, 582). This test-statistic underlines the necessity of applying the three-stage model because the coefficient estimates of the governance ratings in the OLS regressions are likely to be inconsistent (Beiner et al., 2006; Boersch-Supan and Koeke, 2002). Drobetz et al. (2004), for example, argue that differences in growth opportunities might be the primary source of endogeneity (the need for fresh capital and access to capital markets). This is particularly relevant for Tobin's Q, which is regarded as a measure firm value via the perception of growth opportunities. 
coefficients of the explanatory variables, $\varepsilon$ is the error term. The sample contains both UK and GER firms. Q stands for the valuation measure Tobin's Q ( $Q$ is winsorized at $1 \%$ level and is used in log form), and CONTROL is a set of control variables (size is log of total assets, leverage is total debt to total assets, growth is 3 years average growth in net sales, free float is number of shares as free float to total shares outstanding, capital-intensity is PPE to total assets, index membership indicates blue chip firms based on FTSE100 for UK firms and DAX30 for GER firms, UK dummy indicates UK firms). GOVpred is the predicted governance variable from the second stage regressions (either for CGQ or CGI). MILLS is the inverse mills ratio from the first stage regression. TECHNOLOGYpred is the predicted variable TECHNOLOGY, which measures the incremental usefulness of the CGQ (through superior weighting technology and/or private information) relative to our naïve CGI rating. TECHNOLOGY is based on the residuals from cross sectional OLS regressions with the following format: $\mathrm{CGQ}_{i}=\alpha+\beta \mathrm{CGI}_{\mathrm{i}}+\varepsilon$. The regression models contain year- and industry-fixed effects (based on first-digit SIC industry codes), and have standard errors which are heteroskedasticity robust (White, 1980) and one-way clustered at firm level (Gow et al., 2010; Petersen, 2009). The DWH test reports t-statistics of the Durbin-Wu-Hausman (DWH) augmented regression test suggested by Davidson and MacKinnon (1993). The null hypothesis of DWH is that CGQ / CGI / TECHNOLOGY is exogenous. F test provides the F-statistic of the second stage regression of our three stage model (which is consistent with the F-stat of the first stage of the common 2SLS IV model). For the employed instrument variables (one-year lagged CGQ ratings / CGI scores / TECHNOLOGY, and industry-median CGQ ratings / CGI scores / TECHNOLOGY) the Stock-Yogo test statistic - based on the Kleibergen-Paap rk Wald F statistic (instead of Cragg-Donald Wald F statistic due to clustered standard errors; see Baum et al., 2007) - tests the null hypothesis of weak instruments (with $10 \%=19.93$, and $15 \%=11.59$ ). The Sargan-Hansen test statistic (respectively the Hansen's J statistic due to clustered se) is an over-identification test of all instruments (p-values reported). Reported values: coefficient ( $\mathrm{z}$ statistics). $* * *(* *)(*)$ indicates significance at $1 \%(5 \%)(10 \%)$, two-tailed level.

The third stage results show that, after controlling simultaneously for endogeneity and sample selectivity, the coefficient on the CGQ rating now takes the predicted positive sign and becomes significant across all three different sample compositions (Models 1, 4, 7; Table 3 - 8). Thus, in line with the OLS results (Table 3 - 6), we now find strong support for our first prediction that governance quality, as measured by the commercial rating, is positively associated with firm value. With respect to our second prediction, the three-stage results corroborate our original OLS findings. The coefficient estimates of the variable TECHNOLOGY remain insignificant over all three different sample compositions, whereas the naïve CGI score still outperforms the CGQ rating in terms of statistical and economic significance (Models 2 - 3, 5 - 6, 8 - 9; Table 3 - 8).

\subsubsection{Robustness Tests}

\section{Methodology}

We perform several tests to establish the robustness of our main findings. First, we control separately (instead of simultaneously) for endogeneity and sample selection and vary the sample size to assess the sensitivity of our methodology choice. As an alternative to our three-stage approach (Table 3 - 8), we split the model and perform separately Two-StageLeast-Squares (2SLS) and Heckman (Selection) regressions. Untabulated results of both 
specifications are in line with our original findings. ${ }^{66}$

To assess whether our results are affected by a specific time frame during our observation period (2003-2007), we apply a 'stripping out' procedure (e.g., Goncharov and Jacob, 2012). We rerun our basic regression models using samples that each excludes observations for one of our sample years. To that end, we run 45 individual regressions based on all three different sample specifications with a restricted sample size. Untabulated results support the original findings as presented in Table 3 - 6. Specifically, in all cases the coefficient estimates on the variable TECHNOLOGY remain insignificant and the naïve CGI score outperforms the CGQ rating in terms of statistical significance. The magnitude of the governance coefficient's significance, however, varies over the different time specifications, suggesting heterogeneity in the governance-firm value relationship. ${ }^{67}$

In our original setup, we base our analyses on an unbalanced panel of UK and German firms over the years 2003 and 2007. This approach avoids a survivorship bias in our sample composition. A balanced panel sample including only firms which received ratings for the whole period, from 2003 to 2007, would systematically neglect governance ratings of firms which went bankrupt, merged or simply went dark during our sample period. Therefore, we rerun our main regressions using balanced panel samples. Because the coverage by ISS increases over the years in our sample period - especially in the UK with 179 firms rated by ISS in 2003 compared to 415 firms rated by ISS in 2007 - the balanced panel samples are much smaller than our original samples. ${ }^{68}$ Untabulated results of our main regressions with (restricted) balanced panel samples are in line with our findings depicted in Table $3-6 .{ }^{69}$

\section{Measurement of firm value}

We use alternative proxies for our firm value measure to assess the sensitivity of our left-hand side variable choice. First, we repeat all regressions with an unadjusted (pure) Tobin's Q. Untabulated results of our main regressions (Table 3 - 6) confirm our initial findings. ${ }^{70}$

Second, we employ two alternative proxies of firm value which are frequently used in empirical finance and governance literature: market-to-book ratio of equity (e.g., Drobetz et

\footnotetext{
${ }^{66}$ See Appendix $3-2$.

${ }^{67}$ See Appendix 3 - 3.

${ }^{68}$ Combined UK and GER sample with $\mathrm{N}=1,000$; UK sample with $\mathrm{N}=650$; GER sample with $\mathrm{N}=350$.

${ }^{69}$ See Appendix 3 - 3.

${ }^{70}$ See Appendix $3-4$.
} 
al., 2004; Beiner et al., 2006) and market-to-sales ratio (Renders et al., 2010). ${ }^{71}$ Untabulated results support our original findings. Based on the MTB specification, we obtain positive and significant coefficients on CGQ and CGI and insignificant coefficients on TECHNOLOGY. Based on the MTS specification, we obtain a positive and significant coefficient on CGQ in only one out of three possible cases (for the GER sample). The coefficient estimate on CGI, however, becomes significant with positive signs in all three cases (combined and separately for UK \& GER firms), whereas the coefficient estimates on TECHNOLOGY remain either insignificant or become significant but with a negative signs. ${ }^{72}$

\section{Measurement of the naïve governance rating}

Third, we use alternative coding and weighting methods for the CGI rating to assess the sensitivity of our right-hand side CGI variable choice. We repeat our auxiliary regression to estimate TECHNOLGY and our main regressions using a) relative CGI ratings which measure on a yearly base the firm's governance quality with respect to the firm's compliance with the underlying rating criteria, b) governance ratings based on six CGI sub-ratings (board, audit, charter, compensation, progressive practice, and director ownership) via Principal Component Analysis to proxy our initial CGI rating, and c) governance ratings estimated directly on all 47 / 41 ISS CGQ rating criteria via Principal Component Analysis to proxy our initial CGI rating. Untabulated results show that in support of our initial findings, all corresponding TECHNOLOGY variables remain insignificant. Moreover, each of the three alternative CGI ratings clearly outperforms the CGQ rating in terms of statistical significance. $^{73}$

\section{Control variables}

To assess the sensitivity of our control variable choice, we use alternative as well as additional control variables which are frequently used in the empirical finance literature.

\footnotetext{
${ }^{71}$ Since no consensus exists as to which measure best captures firm performance (Dalton et al., 1998) and prior governance literature questions the applicability of accounting-based performance measures in the performancegovernance context (e.g., Bauer et al., 2004), we rely solely on direct measures of firm value. Bauer et al. (2004), for example, argue that firms with low governance standards might be prone to earnings management and therefore report less conservative earnings. Recent empirical results on the relation between governance quality and earnings management support this (e.g., Renders and Vandenbogaerde, 2008).

${ }^{72}$ See Appendix 3 - 4.

${ }^{73}$ See Appendix 3 - 5.
} 
Moreover, we apply a statistical procedure (stepwise regressions) to select our independent variables based on the extended set of control variables. We additionally consider the following control variables: (1) R\&D expenditures to total assets (e.g., Daines, 2001; Bebchuk et al., 2009), (2) current and past return on assets (e.g., Beiner et al., 2006; Bauer et al., 2004; Daines, 2001), (3) capital expenditures to total assets (e.g., Aggarwal et al., 2009; Bebchuk et al., 2009), (4) cash to total assets (e.g., Aggarwal et al., 2009), (5) firm age (e.g., Gompers et al., 2003; Drobetz et al., 2004), (6) risk as the yearly average standard deviation based on monthly stock returns (e.g., Beiner et al., 2006), and (7) indicator variables for negative earnings (loss) in the preceding fiscal period, for IFRS and US-GAAP accounting (e.g., Renders et al., 2010). After testing for multicollinearity, we first extend our main regression models (Table 3 - 6) by all above listed control variables and then perform stepwise regressions in four different versions (forward selection, forward stepwise, backward selection, and backward stepwise regression) to select the independent variables pursuant prespecified significance levels for removal $(\mathrm{pr}=0.2)$ and / or for addition ( $\mathrm{pe}=0.10$ ). Untabulated results of the extended main regression models are in line with our original findings as we obtain positive and significant coefficients on CGQ and CGI in almost all regression specifications, and insignificant coefficients on TECHNOLOGY in all specifications. $^{74}$

\section{Economic Significance}

To shed light on the economic significance of our findings, we calculate for our main regression models (Table 3 - 6) the valuation effect of a one-percent-change, a one-sigmachange, and a min-max-change in the governance ratings (Renders et al., 2010). As an alternative measure of economic significance, we also compute additional variance explained. Untabulated results indicate a substantially higher economic significance of the naïve CGI score as opposed to the commercial CGQ rating over all different measures and over all three samples. For example, for our full sample, an increase of one sigma in the CGI (CGQ) variable results in an average increase of $4.72 \%$ (3.39\%) in Tobin's Q. Using additional variance explained as an alternative indicator of economic significance yields equivalent results. Because we compare both ratings within identical settings, the increase or decrease of explained sum of squares to total sum of squares is a valid indicator of economic significance.

\footnotetext{
${ }^{74}$ See Appendix $3-6$.
} 
Therefore, we examine whether the adjusted $R^{2} s$ of our firm value regressions increase or decrease when using the CGI instead of the CGQ rating. Untabulated results for our basic regression models underline the higher economic significance of the CGI score compared to the commercial CGQ rating over all three different sample compositions. In particular, our naïve CGI score explains $1.43 \%$ (1.71\%) [2.00\%] additional variance in the Tobin's Q specification for the combined sample of UK and German firms (for the sample of UK firms) [for the sample of German firms]. ${ }^{75}$

\subsection{Conclusion}

This paper asks whether and how commercial governance ratings are potentially useful to investors. We investigate the power of those ratings in explaining firm value, and augment prior work by examining in detail the incremental value created by the rating agency's activities of translating public and private information into commercial ratings. To our knowledge, this is the first paper to shed light on the incremental usefulness of a governance agency's proprietary technology. Using data provided by ISS for the UK and the German market, our analyses indicate that, in line with prior work, commercial ratings are positively associated with firm value. However, isolating the incremental contribution of the rating agency's technology, we find no additional explanatory power relative to a naïve rating that we construct from the observable, publicly available inputs which ISS uses. This suggests that the rating agency does not create value by assembling a rating from observable data using its proprietary weighting scheme, and supplementing private information.

These results are robust to various different specifications, endogeneity and sample selectivity. In particular, they hold both for the UK and for the German setting, which rules out the explanation that U.S. domiciled rating agencies are more adept at rating firms located in shareholder-oriented governance systems. Our findings cast doubt on the incremental usefulness of the rating agencies' information processing activities, and suggest that the core competitive advantage of these institutions may rather lay in the activity of collecting publicly available governance data, creating transaction cost savings for investors, or other, hitherto unexplored factors.

The implications of our findings are manifold. We confirm prior findings from Europe

\footnotetext{
${ }^{75}$ See Appendix 3 - 7.
} 
of a positive association of governance quality and firm value. These findings are important for corporate management and investors in Europe as they suggest that high governance scores imply to some extent higher firm valuation. Our analysis of the incremental usefulness of rating agencies intermediation activities provides novel insights into the economics of commercial CG rating agencies. These findings are important for investment managers and practitioners, as they indicate that CG rating vendors may at least not create value in the way that is widely assumed.

Our results are subject to the limitation that we only analyze the rating of one particular firm, ISS, and that we are unable to incorporate into our models other potential sources of value creation by commercial rating vendors. This creates various research opportunities. Future research may investigate the comparative differences in how rating agencies create value. Another path would be to challenge the robustness of our findings by conducting our analyses for alternative time frames. Finally, future work should investigate more comprehensively the economic explanation of commercial rating agencies, to enable us to better comprehend the role of these information intermediaries in capital markets. 


\subsection{Appendix}

Appendix 3 - 1: Definition of Variables

\begin{tabular}{|c|c|c|c|}
\hline SHORT CUT & \multicolumn{2}{|l|}{ VARIABLE } & DEFINITION \\
\hline \multicolumn{4}{|c|}{ Corporate Governance Measures } \\
\hline CGQ & $\begin{array}{l}\text { Corporate } \\
\text { Quotient }\end{array}$ & Governance & $\begin{array}{l}\text { CGQ is a commercial corporate governance rating from ISS. We } \\
\text { employ for our study CGQ "Country Ranking" scores (final rating } \\
\text { scores are provided by ISS). }\end{array}$ \\
\hline \multirow[t]{2}{*}{ CGI } & \multirow{2}{*}{\multicolumn{2}{|c|}{$\begin{array}{l}\text { Corporate } \\
\text { Indicator }\end{array}$}} & $\begin{array}{l}\text { CGI is a naïve corporate governance score based on the same publicly } \\
\text { available governance data as the CGQ rating. It is equally weighted, } \\
\text { not adjusted for yearly trends, and reflects as a relative measure - } \\
\text { similar to the CGQ "Country Ranking" scores - the governance } \\
\text { quality relative to other firms in the same year and same country (raw } \\
\text { data of the ISS CGQ provisions are provided by ISS). }\end{array}$ \\
\hline & & & $\begin{array}{l}\text { The CGI is defined as } C G I_{i t c}=\frac{\left(p_{i t c}-1\right)}{\left(m_{t c}-1\right)} \times 100 \text {, whereas } p_{i t c} \text { equals } \\
\text { the rank of firm i in year } \mathrm{t} \text { from country c and } m_{t c} \text { the sum of all } \\
\text { ranked firms in year } \mathrm{t} \text { and country c. The rank is based on equally } \\
\text { weighted scores of all compliance rates with ISS's governance criteria } \\
\text { for each firm i in year } t \text { and country c ( } 47 \text { CGQ criteria for the UK } \\
\text { setting and } 41 \text { CGQ criteria for the German setting). For example, a } \\
\text { German firm which complied with } 17 \text { ISS's governance criteria in } \\
2007 \text { (out of } 41) \text { received a rank of } 43 \text { (out of } 86) \text { and a corresponding } \\
\text { CGI score of } 49.41((43-1) /(86-1)) * 100) \text {. The CGI score of } 49.41 \\
\text { indicates that the firm's compliance with ISS rating criteria was } \\
\text { higher than the compliance of } 49.41 \% \text { of all other rated firms in the } \\
\text { same year and country. }\end{array}$ \\
\hline \multicolumn{3}{|c|}{ TECHNOLOGY } & $\begin{array}{l}\text { TECHNOLOGY measures the incremental contribution of the rating } \\
\text { vendor's weighting technology as well as the vendor's ability to } \\
\text { incorporate private information into the commercial rating. For } \\
\text { computational issues, see Table } 3-3 \text {. }\end{array}$ \\
\hline
\end{tabular}

\section{Firm Value Measures}

\begin{tabular}{|c|c|c|}
\hline Q & Tobin’s Q & $\begin{array}{l}\text { Tobin's } Q \text { measures firm valuation by average fiscal year's market } \\
\text { value (dwta }+ \text { mv - dwse) deflated by average fiscal year's total assets } \\
\text { (dwta) }\end{array}$ \\
\hline \multicolumn{3}{|c|}{ Control Variables } \\
\hline Size & Log of total assets & Size is log of average fiscal year's total assets (dwta). \\
\hline Growth & Growth in net sales & Growth is three years average growth in net sales (wc01001). \\
\hline Leverage & Total debt to total assets & Leverage is total debt (wc03255) to total assets (wc02999). \\
\hline Ownership & Free float & $\begin{array}{l}\text { Ownership is number of shares in free float to number of total shares } \\
\text { outstanding (noshff). }\end{array}$ \\
\hline $\begin{array}{l}\text { Capital- } \\
\text { Intensity }\end{array}$ & PPE to total assets & $\begin{array}{l}\text { Capital-Intensity is property, plant \& equipment (wc02501) to total } \\
\text { assets (wc02999). }\end{array}$ \\
\hline $\begin{array}{l}\text { Index } \\
\text { Membership }\end{array}$ & $\begin{array}{l}\text { Blue chip index } \\
\text { membership }\end{array}$ & $\begin{array}{l}\text { Index Membership is blue chip index membership based on FTSE100 } \\
\text { for UK firms and based on DAX30 for German firms (wc05661). }\end{array}$ \\
\hline $\begin{array}{l}\text { Year } \\
\text { dummies }\end{array}$ & Year indicators & Year dummies are based on date of fiscal year end (wc05350). \\
\hline $\begin{array}{l}\text { Industry } \\
\text { dummies }\end{array}$ & Industry indicators & $\begin{array}{l}\text { Industry dummies are based on first-digit SIC industry segments } \\
\text { (wc07021). }\end{array}$ \\
\hline \multicolumn{3}{|c|}{ Selection Criteria } \\
\hline DPS & Dividends per share & DPS is dividend per share (wc05101). \\
\hline $\begin{array}{l}\text { Pension } \\
\text { Funds }\end{array}$ & Pension funds holding & $\begin{array}{l}\text { Pension Funds is number of share in pension funds holding to total } \\
\text { shares outstanding (noshpf). }\end{array}$ \\
\hline
\end{tabular}


Appendix 3 - 1: Definition of Variables (continued)

\begin{tabular}{|c|c|c|}
\hline SHORT CUT & VARIABLE & DEFINITION \\
\hline \multicolumn{3}{|c|}{ Corporate Governance Measures (Robustness Section) } \\
\hline $\mathrm{CGI}_{1}$ & $\begin{array}{l}\text { Corporate Governance } \\
\text { Indicator }_{1}\end{array}$ & $\begin{array}{l}\mathrm{CGI}_{1} \text { is a relative CG rating which measures on a yearly base the } \\
\text { firm's governance quality with respect to the firm's compliance with } \\
\text { the underlying ISS CGQ rating criteria. }\end{array}$ \\
\hline $\mathrm{CGI}_{2}$ & $\begin{array}{l}\text { Corporate Governance } \\
\text { Indicator }_{2}\end{array}$ & $\begin{array}{l}\mathrm{CGI}_{2} \text { is a } \mathrm{CG} \text { rating which is estimated on six CGI sub-ratings } \\
\text { (similar to the CGI rating, the sub-scores are naïve and additive } \\
\text { constructed) - board, audit, charter, compensation, progressive } \\
\text { practice, and director ownership - via Principal Component Analysis. }\end{array}$ \\
\hline $\mathrm{CGI}_{3}$ & $\begin{array}{l}\text { Corporate } \\
\text { Indicator }_{3}\end{array}$ & $\begin{array}{l}\mathrm{CGI}_{3} \text { is a } \mathrm{CG} \text { rating which is estimated directly on all } 47 \text { ISS rating } \\
\text { criteria in case of the UK sample and on all } 41 \text { ISS rating criteria in } \\
\text { case of the German sample via Principal Component Analysis. }\end{array}$ \\
\hline \multicolumn{3}{|c|}{ Firm Value Measures (Robustness Section) } \\
\hline MTB & $\begin{array}{l}\text { Market-to-Book ratio of } \\
\text { equity }\end{array}$ & $\begin{array}{l}\text { MTB measures firm value and equals market value of equity (mv) } \\
\text { divided by book value of equity (dwse). }\end{array}$ \\
\hline MTS & Market-to-Sales ratio & $\begin{array}{l}\text { MTS measures firm value and equals market value of equity (mv) } \\
\text { divided by net sales (dwsl). }\end{array}$ \\
\hline \multicolumn{3}{|c|}{ Control Variables (Robustness Section) } \\
\hline Firm Age & Log of firm age & $\begin{array}{l}\text { Firm Age is based on data of incorporation (wc18273) for UK firms } \\
\text { and company founded data (wc18272) for German firms. }\end{array}$ \\
\hline Risk & $\begin{array}{l}\text { Standard deviation of } \\
\text { stock returns }\end{array}$ & $\begin{array}{l}\text { Risk is measured as the yearly average standard deviation based on } \\
\text { monthly stock returns (wc05015 - wc } 05070) \text {. }\end{array}$ \\
\hline R\&D_TA & $\begin{array}{l}\mathrm{R} \& \mathrm{D} \text { expenditures to } \\
\text { total assets }\end{array}$ & $\begin{array}{l}\text { R\&D_TA is measured as research \& development expenses / } \\
\text { expenditures ( } \mathrm{wc} 01201) \text { to total assets ( } \mathrm{wc} 02999) \text {. }\end{array}$ \\
\hline $\mathrm{ROA}_{t}$ & Current period ROA & $\begin{array}{l}\mathrm{ROA}_{t} \text { is measured as net income before extraordinary items } \\
(\mathrm{wc} 04001) \text { to total assets (wc02999). }\end{array}$ \\
\hline $\mathrm{ROA}_{\mathrm{t}-1}$ & Past period ROA & $\begin{array}{l}\mathrm{ROA}_{\mathrm{t}-1} \text { is measured as net income before extraordinary items } \\
(\mathrm{wc} 04001) \text { to total assets ( } \mathrm{wc} 02999) \text { for the preceding period. }\end{array}$ \\
\hline CAPEX & $\begin{array}{l}\text { Capital expenditures to } \\
\text { total assets }\end{array}$ & $\begin{array}{l}\text { CAPEX is measured as capital expenditures (wc04601) to total assets } \\
\text { (wc02999). }\end{array}$ \\
\hline CASH_TA & Cash to total assets & $\begin{array}{l}\text { CASH_TA is measured as net cash flow from operations (wc04860) } \\
\text { to total assets (wc02999). }\end{array}$ \\
\hline Loss & Negative net income & $\begin{array}{l}\text { Loss is a dummy variable indicating negative net income (wc01751< } \\
0 \text { ). }\end{array}$ \\
\hline IFRS & IFRS accounting & $\begin{array}{l}\text { IFRS is a dummy variable indicating IFRS accounting } \\
\text { (wc07536 ="IFRS"). }\end{array}$ \\
\hline USGAAP & US-GAAP accounting & $\begin{array}{l}\text { USGAAP is a dummy variable indicating US-GAAP accounting } \\
\text { (wc07536 = "US standards"). }\end{array}$ \\
\hline
\end{tabular}


Appendix 3 - 2: Two-Stage-Least-Squares (2SLS) \& Heckman Selection

Panel A. Two-Stage-Least-Squares (2SLS) Regressions

\begin{tabular}{|c|c|c|c|c|c|c|c|c|c|c|}
\hline \multirow{3}{*}{ Independent Variables } & \multirow{3}{*}{$\begin{array}{c}\text { Pred. } \\
\text { Sign }\end{array}$} & \multicolumn{9}{|c|}{ Firm Value Measure: Tobin's Q (dependent variable) } \\
\hline & & \multicolumn{3}{|c|}{ UK \& GER Sample (M1-M3) } & \multicolumn{3}{|c|}{ UK Sample (M4-M6) } & \multicolumn{3}{|c|}{ GER Sample (M7-M9) } \\
\hline & & Model 1 & Model 2 & Model 3 & Model 4 & Model 5 & Model 6 & Model 7 & Model 8 & Model 9 \\
\hline CGQpred & + & $\begin{array}{c}.003^{* * *} \\
(3.03)\end{array}$ & & & $\begin{array}{c}.003^{* * * *} \\
(2.62)\end{array}$ & & & $\begin{array}{c}.005^{* * * *} \\
(2.80)\end{array}$ & & \\
\hline $\mathbf{C G I}_{\text {pred }}$ & + & & $\begin{array}{c}.004 * * * \\
(4.01)\end{array}$ & & & $\begin{array}{c}.004 * * * \\
(3.63)\end{array}$ & & & $\begin{array}{c}.006^{* * *} \\
(3.71)\end{array}$ & \\
\hline TECH $_{\text {pred }}$ & + & & & $\begin{array}{c}.002 \\
(0.84) \\
\end{array}$ & & & $\begin{array}{c}.002 \\
(0.80) \\
\end{array}$ & & & $\begin{array}{c}.000 \\
(0.15) \\
\end{array}$ \\
\hline CGI & + & & & $\begin{array}{c}.002 * * * \\
(4.70)\end{array}$ & & & $\begin{array}{c}.002^{* * *} \\
(3.68)\end{array}$ & & & $\begin{array}{c}003 \\
(3.88)\end{array}$ \\
\hline TECH & + & & $\begin{array}{c}.001 \\
(0.85) \\
\end{array}$ & & & $\begin{array}{c}.000 \\
(0.57) \\
\end{array}$ & & & $\begin{array}{c}.001 \\
(1.06) \\
\end{array}$ & \\
\hline Firm controls & & Yes & Yes & Yes & Yes & Yes & Yes & Yes & Yes & Yes \\
\hline Year fixed effects & & Yes & Yes & Yes & Yes & Yes & Yes & Yes & Yes & Yes \\
\hline Industry fixed effects & & Yes & Yes & Yes & Yes & Yes & Yes & Yes & Yes & Yes \\
\hline Clustered (firm) & & Yes & Yes & Yes & Yes & Yes & Yes & Yes & Yes & Yes \\
\hline Adj. $R^{2}$ & & .3100 & .3094 & .3191 & .3125 & .3094 & .3178 & .3871 & .3678 & .4334 \\
\hline Sample Size & & 1506 & 1506 & 1506 & 1191 & 1191 & 1191 & 315 & 315 & 315 \\
\hline
\end{tabular}

Panel B. Heckman (Selection) Regressions

\begin{tabular}{|c|c|c|c|c|c|c|c|c|c|c|}
\hline \multirow{3}{*}{ Independent Variables } & \multirow{3}{*}{$\begin{array}{c}\text { Pred. } \\
\text { Sign }\end{array}$} & \multicolumn{9}{|c|}{ Firm Value Measure: Tobin's Q (dependent variable) } \\
\hline & & \multicolumn{3}{|c|}{ UK \& GER Sample (M1-M3) } & \multicolumn{3}{|c|}{ UK Sample (M4-M6) } & \multicolumn{3}{|c|}{ GER Sample (M7-M9) } \\
\hline & & Model 1 & Model 2 & Model 3 & Model 4 & Model 5 & Model 6 & Model 7 & Model 8 & Model 9 \\
\hline \multirow[t]{2}{*}{ CGQ } & + & $.001 * * *$ & & & $.001 * * *$ & & & .001 & & \\
\hline & & $(3.50)$ & & & $(3.23)$ & & & $(1.44)$ & & \\
\hline \multirow[t]{2}{*}{ CGI } & + & & $.002 * * *$ & $.002 * * *$ & & $.002 * * *$ & $.002 * * *$ & & $.001 * *$ & $.001 * *$ \\
\hline & & & $(4.73)$ & $(4.72)$ & & $(4.60)$ & $(4.59)$ & & $(2.35)$ & $(2.31)$ \\
\hline \multirow[t]{2}{*}{ ТЕСН } & + & & & -.000 & & & -.000 & & & -.001 \\
\hline & & & & $(-0.01)$ & & & $(-0.17)$ & & & $(-0.60)$ \\
\hline \multirow[t]{2}{*}{ INVERSE_MILLS } & & $.152 * *$ & $.154 * *$ & $.154 * *$ & $.243 * * *$ & $.248 * * *$ & $.248 * * *$ & -.082 & -.080 & -.082 \\
\hline & & $(2.27)$ & $(2.29)$ & $(2.29)$ & $(3.09)$ & $(3.16)$ & $(3.16)$ & $(-0.84)$ & $(-0.83)$ & $(-0.85)$ \\
\hline Firm controls & & Yes & Yes & Yes & Yes & Yes & Yes & Yes & Yes & Yes \\
\hline Year fixed effects & & Yes & Yes & Yes & Yes & Yes & Yes & Yes & Yes & Yes \\
\hline Industry fixed effects & & Yes & Yes & Yes & Yes & Yes & Yes & Yes & Yes & Yes \\
\hline Clustered (firm) & & Yes & Yes & Yes & Yes & Yes & Yes & Yes & Yes & Yes \\
\hline Adj. $\mathrm{R}^{2}$ & & .3289 & .3337 & .3334 & .3392 & .3454 & .3451 & .3748 & .3818 & .3808 \\
\hline Sample Size & & 2075 & 2075 & 2075 & 1667 & 1667 & 1667 & 408 & 408 & 408 \\
\hline
\end{tabular}

Notes: The underlying regression models for Panel A are: $Q_{i t}=\alpha+\beta_{1}$ GOVpred ${ }_{i t}+\sum \gamma$ CONTROL $_{i t}+$ $\sum \delta Y E A R_{i t}+\sum \varphi I_{i t}+\varepsilon, Q_{i t}=\alpha+\beta_{1}$ CGIpred $_{i t}+\beta_{2}$ TECHNOLOGY $_{i t}+\sum \gamma$ CONTROL $_{i t}+\sum \delta Y E A R_{i t}$ $+\sum \varphi I N D_{i t}+\varepsilon$, and $Q_{i t}=\alpha+\beta_{1} C G I_{i t}+\beta_{2}$ TECHNOLOGYpred ${ }_{i t}+\sum \gamma$ CONTROL $_{i t}+\sum \delta Y E A R_{i t}+\sum \varphi I N D_{i t}+\varepsilon$, where $\alpha$ represents the constant term, $\beta, \gamma, \delta, \varphi$, and $\omega$ are the coefficients of the explanatory variables, $\varepsilon$ is the error term. The underlying regression models for Panel B are: $Q_{i t}=\alpha+\beta_{1} G O V_{i t}+\beta_{2} M I L L S_{i t}+\sum \gamma C O N T R O L_{i t}$ $+\sum \delta Y E A R_{i t}+\sum \varphi I N D_{i t}+\varepsilon$, and $Q_{i t}=\alpha+\beta_{1} C_{i t}+\beta_{2}$ TECHNOLOGY $i t+\beta_{3}$ MILLS $_{i t}+\sum \gamma C O N T R O L_{i t}+$ $\sum \delta Y E A R_{i t}+\sum \varphi I N D_{i t}+\varepsilon$, where $\alpha$ represents the constant term, $\beta, \gamma, \delta, \varphi$, and $\omega$ are the coefficients of the explanatory variables, $\varepsilon$ is the error term. The sample contains both UK and GER firms. Q stands for the valuation measure Tobin's Q ( $Q$ is winsorized at $1 \%$ level and is used in log form), and CONTROL is a set of control variables (Size is log of total assets, Leverage is total debt to total assets, Growth is 3 years average growth in net sales, free float is number of shares as free float to total shares outstanding, Capital-Intensity is PPE to total assets, Index Membership indicates blue chip firms based on FTSE100 for UK firms and DAX30 for GER firms, UK dummy indicates UK firms). GOVpred is the predicted governance variable from the second stage regressions (either for CGQ or CGI). MILLS is the inverse mills ratio from the first stage regression. TECHNOLOGYpred (TECHpred) is the predicted measure of TECHNOLOGY (TECH), a measure of the incremental usefulness of the CGQ (through superior weighting technology and / or private information) relative to our naïve CGI rating. TECHNOLOGY is based on the residuals from cross sectional OLS regressions with the following format: $\mathrm{CGQ}_{\mathrm{i}}=\alpha+\beta \mathrm{CGI}_{\mathrm{i}}+\varepsilon$. The regression models contain year- and industry-fixed effects (based on first-digit SIC industry codes), and have standard errors which are heteroskedasticity robust (White, 1980) and one-way clustered at firm level (Gow et al., 2010; Petersen, 2009). Reported values: coefficient (z-statistics). $* * *(* *)(*)$ indicates significance at $1 \%(5 \%)(10 \%)$, two-tailed level. 
Appendix 3 - 3: Basic OLS Model with restricted Sample Size

Panel A. Basic OLS Model without Observations from Year 2003

\begin{tabular}{|c|c|c|c|c|c|c|c|c|c|c|}
\hline \multirow{3}{*}{ Independent VAR } & \multirow{3}{*}{$\begin{array}{l}\text { Pred. } \\
\text { Sign }\end{array}$} & \multicolumn{9}{|c|}{ Firm Value Measure: Tobin's Q (dependent variable) } \\
\hline & & \multicolumn{3}{|c|}{ UK \& GER Sample (M1-M3) } & \multicolumn{3}{|c|}{ UK Sample (M4-M6) } & \multicolumn{3}{|c|}{ GER Sample (M7-M9) } \\
\hline & & Model 1 & Model 2 & Model 3 & Model 4 & Model 5 & Model 6 & Model 7 & Model 8 & Model 9 \\
\hline CGQ & + & $\begin{array}{c}.001^{* * *} \\
(3.46)\end{array}$ & & & $\begin{array}{c}.001^{* * * *} \\
(2.80)\end{array}$ & & & $\begin{array}{c}.002^{* * *} \\
(2.71)\end{array}$ & & \\
\hline CGI & + & & $\begin{array}{c}.002 * * * \\
(4.44)\end{array}$ & $\begin{array}{c}.002 * * * \\
(4.45)\end{array}$ & & $\begin{array}{c}.002 * * * \\
(3.79)\end{array}$ & $\begin{array}{c}.002 * * * \\
(3.78)\end{array}$ & & $\begin{array}{c}.002 * * * \\
(3.28)\end{array}$ & $\begin{array}{c}.002 * * * \\
(3.30)\end{array}$ \\
\hline ТЕCH & + & & & $\begin{array}{c}.000 \\
(0.33)\end{array}$ & & & $\begin{array}{c}.000 \\
(0.06)\end{array}$ & & & $\begin{array}{c}.000 \\
(0.31)\end{array}$ \\
\hline Firm controls & & Yes & Yes & Yes & Yes & Yes & Yes & Yes & Yes & Yes \\
\hline Year fixed effects & & Yes & Yes & Yes & Yes & Yes & Yes & Yes & Yes & Yes \\
\hline Industry fixed effects & & Yes & Yes & Yes & Yes & Yes & Yes & Yes & Yes & Yes \\
\hline Clustered (firm) & & Yes & Yes & Yes & Yes & Yes & Yes & Yes & Yes & Yes \\
\hline Adj. $R^{2}$ & & .3091 & .3137 & .3133 & .3111 & .3156 & .3151 & .4177 & .4280 & .4264 \\
\hline Sample Size & & 1829 & 1829 & 1829 & 1503 & 1503 & 1503 & 326 & 326 & 326 \\
\hline
\end{tabular}

Panel B. Basic OLS Model without Observations from Year 2004

\begin{tabular}{|c|c|c|c|c|c|c|c|c|c|c|}
\hline \multirow{3}{*}{ Independent VAR } & \multirow{3}{*}{$\begin{array}{l}\text { Pred. } \\
\text { Sign }\end{array}$} & \multicolumn{9}{|c|}{ Firm Value Measure: Tobin's Q (dependent variable) } \\
\hline & & \multicolumn{3}{|c|}{ UK \& GER Sample (M1-M3) } & \multicolumn{3}{|c|}{ UK Sample (M4-M6) } & \multicolumn{3}{|c|}{ GER Sample (M7-M9) } \\
\hline & & Model 1 & Model 2 & Model 3 & Model 4 & Model 5 & Model 6 & Model 7 & Model 8 & Model 9 \\
\hline CGQ & + & $\begin{array}{c}.001^{* * *} \\
(2.72)\end{array}$ & & & $\begin{array}{c}.001^{* * * *} \\
(2.91)\end{array}$ & & & $\begin{array}{c}.000 \\
(0.54)\end{array}$ & & \\
\hline CGI & + & & $\begin{array}{c}.002^{* * *} \\
(4.11)\end{array}$ & $\begin{array}{c}.002 * * * \\
(4.08)\end{array}$ & & $\begin{array}{c}.002 * * * \\
(4.27)\end{array}$ & $\begin{array}{c}.002 * * * \\
(4.25)\end{array}$ & & $\begin{array}{c}.001 \\
(1.57)\end{array}$ & $\begin{array}{c}.001 \\
(1.53)\end{array}$ \\
\hline TECH & + & & & $\begin{array}{c}-.000 \\
(-0.40)\end{array}$ & & & $\begin{array}{l}-.000 \\
(-0.26)\end{array}$ & & & $\begin{array}{l}-.001 \\
(-0.83)\end{array}$ \\
\hline Firm controls & & Yes & Yes & Yes & Yes & Yes & Yes & Yes & Yes & Yes \\
\hline Year fixed effects & & Yes & Yes & Yes & Yes & Yes & Yes & Yes & Yes & Yes \\
\hline Industry fixed effects & & Yes & Yes & Yes & Yes & Yes & Yes & Yes & Yes & Yes \\
\hline Clustered (firm) & & Yes & Yes & Yes & Yes & Yes & Yes & Yes & Yes & Yes \\
\hline Adj. $R^{2}$ & & .3084 & .3135 & .3132 & .3115 & .3177 & .3173 & .3480 & .3538 & .3534 \\
\hline Sample Size & & 1827 & 1827 & 1827 & 1498 & 1498 & 1498 & 329 & 329 & 329 \\
\hline
\end{tabular}

Panel C. Basic OLS Model without Observations from Year 2005

\begin{tabular}{|c|c|c|c|c|c|c|c|c|c|c|}
\hline \multirow{3}{*}{ Independent VAR } & \multirow{3}{*}{$\begin{array}{l}\text { Pred. } \\
\text { Sign }\end{array}$} & \multicolumn{9}{|c|}{ Firm Value Measure: Tobin's Q (dependent variable) } \\
\hline & & \multicolumn{3}{|c|}{ UK \& GER Sample (M1-M3) } & \multicolumn{3}{|c|}{ UK Sample (M1-M3) } & \multicolumn{3}{|c|}{ GER Sample (M1-M3) } \\
\hline & & Model 1 & Model 2 & Model 3 & Model 4 & Model 5 & Model 6 & Model 7 & Model 8 & Model 9 \\
\hline CGQ & + & $\begin{array}{c}.001 * * * \\
(3.28)\end{array}$ & & & $\begin{array}{c}.001 * * * \\
(3.05)\end{array}$ & & & $\begin{array}{c}.001 \\
(1.43)\end{array}$ & & \\
\hline CGI & + & & $\begin{array}{c}.002 * * * \\
(4.36)\end{array}$ & $\begin{array}{c}.002 * * * \\
(4.36)\end{array}$ & & $\begin{array}{c}.002 * * * \\
(4.18)\end{array}$ & $\begin{array}{c}.002 * * * \\
(4.18)\end{array}$ & & $\begin{array}{l}.001 * * \\
(2.08)\end{array}$ & $\begin{array}{l}.001 * * \\
(2.06)\end{array}$ \\
\hline ТЕСН & + & & & $\begin{array}{c}-.000 \\
(-0.01)\end{array}$ & & & $\begin{array}{c}-.000 \\
(-0.05)\end{array}$ & & & $\begin{array}{c}-.000 \\
(-0.38)\end{array}$ \\
\hline Firm controls & & Yes & Yes & Yes & Yes & Yes & Yes & Yes & Yes & Yes \\
\hline Year fixed effects & & Yes & Yes & Yes & Yes & Yes & Yes & Yes & Yes & Yes \\
\hline Industry fixed effects & & Yes & Yes & Yes & Yes & Yes & Yes & Yes & Yes & Yes \\
\hline Clustered (firm) & & Yes & Yes & Yes & Yes & Yes & Yes & Yes & Yes & Yes \\
\hline Adj. $\mathrm{R}^{2}$ & & .3213 & .3262 & .3257 & .3227 & .3287 & .3281 & .3615 & .3675 & .3657 \\
\hline Sample Size & & 1547 & 1547 & 1547 & 1218 & 1218 & 1218 & 329 & 329 & 329 \\
\hline
\end{tabular}




\section{THE USEFULNESS OF CORPORATE GOVERNANCE RATINGS - INSIGHTS FROM EUROPEAN SETTINGS}

\section{Appendix 3 - 3: Basic OLS Model with restricted Sample Size (continued)}

Panel D. Basic OLS Model without Observations from Year 2006

\begin{tabular}{|c|c|c|c|c|c|c|c|c|c|c|}
\hline \multirow{3}{*}{ Independent VAR } & \multirow{3}{*}{$\begin{array}{l}\text { Pred. } \\
\text { Sign }\end{array}$} & \multicolumn{9}{|c|}{ Firm Value Measure: Tobin's Q (dependent variable) } \\
\hline & & \multicolumn{3}{|c|}{ UK \& GER Sample (M1-M3) } & \multicolumn{3}{|c|}{ UK Sample (M4-M6) } & \multicolumn{3}{|c|}{ GER Sample (M7-M9) } \\
\hline & & Model 1 & Model 2 & Model 3 & Model 4 & Model 5 & Model 6 & Model 7 & Model 8 & Model 9 \\
\hline CGQ & + & $\begin{array}{l}.001^{* *} \\
(2.32)\end{array}$ & & & $\begin{array}{l}.001 * * \\
(2.58)\end{array}$ & & & $\begin{array}{c}.000 \\
(0.76)\end{array}$ & & \\
\hline CGI & + & & $\begin{array}{c}.001^{* * *} \\
(3.64)\end{array}$ & $\begin{array}{c}.001 * * * \\
(3.60)\end{array}$ & & $\begin{array}{c}.002 * * * \\
(4.03)\end{array}$ & $\begin{array}{c}.002 * * * \\
(4.00)\end{array}$ & & $\begin{array}{l}.001 * \\
(1.74)\end{array}$ & $\begin{array}{l}.001^{*} \\
(1.69)\end{array}$ \\
\hline TECH & + & & & $\begin{array}{c}-.000 \\
(-0.65) \\
\end{array}$ & & & $\begin{array}{c}-.000 \\
(-0.56) \\
\end{array}$ & & & $\begin{array}{c}-.001 \\
(-1.06) \\
\end{array}$ \\
\hline Firm controls & & Yes & Yes & Yes & Yes & Yes & Yes & Yes & Yes & Yes \\
\hline Year fixed effects & & Yes & Yes & Yes & Yes & Yes & Yes & Yes & Yes & Yes \\
\hline Industry fixed effects & & Yes & Yes & Yes & Yes & Yes & Yes & Yes & Yes & Yes \\
\hline Clustered (firm) & & Yes & Yes & Yes & Yes & Yes & Yes & Yes & Yes & Yes \\
\hline Adj. $R^{2}$ & & 3149 & .3192 & .3190 & .3216 & .3279 & 3276 & .3342 & .3396 & .3396 \\
\hline Sample Size & & 1553 & 1553 & 1553 & 1227 & 1227 & 1227 & 326 & 326 & 326 \\
\hline
\end{tabular}

Panel E. Basic OLS Model without Observations from Year 2007

\begin{tabular}{|c|c|c|c|c|c|c|c|c|c|c|}
\hline \multirow{3}{*}{ Independent VAR } & \multirow{3}{*}{$\begin{array}{l}\text { Pred. } \\
\text { Sign }\end{array}$} & \multicolumn{9}{|c|}{ Firm Value Measure: Tobin's Q (dependent variable) } \\
\hline & & \multicolumn{3}{|c|}{ UK \& GER Sample (M1-M3) } & \multicolumn{3}{|c|}{ UK Sample (M4-M6) } & \multicolumn{3}{|c|}{ GER Sample (M7-M9) } \\
\hline & & Model 1 & Model 2 & Model 3 & Model 4 & Model 5 & Model 6 & Model 7 & Model 8 & Model 9 \\
\hline CGQ & + & $\begin{array}{c}.001^{* * *} \\
(2.68)\end{array}$ & & & $\begin{array}{c}.001^{* * *} \\
(2.69)\end{array}$ & & & $\begin{array}{c}.001 \\
(1.29)\end{array}$ & & \\
\hline CGI & + & & $\begin{array}{c}.002 * * * \\
(3.66)\end{array}$ & $\begin{array}{c}.002 * * * \\
(3.65)\end{array}$ & & $\begin{array}{c}.002 * * * \\
(3.72)\end{array}$ & $\begin{array}{c}.002 * * * \\
(3.71)\end{array}$ & & $\begin{array}{l}.001 * * \\
(2.48)\end{array}$ & $\begin{array}{l}.001 * * \\
(2.42)\end{array}$ \\
\hline TECH & + & & & $\begin{array}{c}-.000 \\
(-0.11)\end{array}$ & & & $\begin{array}{c}-.000 \\
(-0.05)\end{array}$ & & & $\begin{array}{l}-.001 \\
(-1.09)\end{array}$ \\
\hline Firm controls & & Yes & Yes & Yes & Yes & Yes & Yes & Yes & Yes & Yes \\
\hline Year fixed effects & & Yes & Yes & Yes & Yes & Yes & Yes & Yes & Yes & Yes \\
\hline Ind fixed effects & & Yes & Yes & Yes & Yes & Yes & Yes & Yes & Yes & Yes \\
\hline Clustered (firm) & & Yes & Yes & Yes & Yes & Yes & Yes & Yes & Yes & Yes \\
\hline Adj. $R^{2}$ & & .3228 & .3266 & .3262 & .3190 & .3236 & .3231 & .3803 & .3888 & .3889 \\
\hline Sample Size & & 1588 & 1588 & 1588 & 1262 & 1262 & 1262 & 326 & 326 & 326 \\
\hline
\end{tabular}

Panel F. Basic OLS Model with Balanced Sample

\begin{tabular}{|c|c|c|c|c|c|c|c|c|c|c|}
\hline \multirow{3}{*}{ Independent VAR } & \multirow{3}{*}{$\begin{array}{l}\text { Pred. } \\
\text { Sign }\end{array}$} & \multicolumn{9}{|c|}{ Firm Value Measure: Tobin's Q (dependent variable) } \\
\hline & & \multicolumn{3}{|c|}{ UK \& GER Sample (M1-M3) } & \multicolumn{3}{|c|}{ UK Sample (M4-M6) } & \multicolumn{3}{|c|}{ GER Sample (M7-M9) } \\
\hline & & Model 1 & Model 2 & Model 3 & Model 4 & Model 5 & Model 6 & Model 7 & Model 8 & Model 9 \\
\hline CGQ & + & $\begin{array}{c}0.001 * * \\
(2.44)\end{array}$ & & & $\begin{array}{c}0.001 * * \\
(2.39)\end{array}$ & & & $\begin{array}{c}0.001 * * \\
(2.32)\end{array}$ & & \\
\hline CGI & + & & $\begin{array}{c}0.002 * * * \\
(2.99)\end{array}$ & $\begin{array}{c}0.002 * * * \\
(3.00)\end{array}$ & & $\begin{array}{c}0.002 * * \\
(2.53)\end{array}$ & $\begin{array}{c}0.002 * * \\
(2.58)\end{array}$ & & $\begin{array}{c}0.002 * * * \\
(2.85)\end{array}$ & $\begin{array}{c}0.002 * * * \\
(2.86)\end{array}$ \\
\hline ТЕСН & + & & & $\begin{array}{l}0.000 \\
(0.21)\end{array}$ & & & $\begin{array}{l}0.001 \\
(0.79)\end{array}$ & & & $\begin{array}{r}0.000 \\
(0.07)\end{array}$ \\
\hline Firm controls & & Yes & Yes & Yes & Yes & Yes & Yes & Yes & Yes & Yes \\
\hline Year fixed effects & & Yes & Yes & Yes & Yes & Yes & Yes & Yes & Yes & Yes \\
\hline Ind fixed effects & & Yes & Yes & Yes & Yes & Yes & Yes & Yes & Yes & Yes \\
\hline Clustered (firm) & & Yes & Yes & Yes & Yes & Yes & Yes & Yes & Yes & Yes \\
\hline Adj. $\mathrm{R}^{2}$ & & .3504 & .3544 & .3538 & .3935 & .3949 & .3947 & .3979 & .4046 & .4028 \\
\hline Sample Size & & 1000 & 1000 & 1000 & 650 & 650 & 650 & 350 & 350 & 350 \\
\hline
\end{tabular}

Notes: The underlying regression models are: $Q_{i t}=\alpha+\beta_{1} C G Q_{i t}+\sum \gamma C O N T R O L_{i t}+\sum \delta Y E A R_{i t}+\sum \varphi I N D_{i t}+\varepsilon$, and $Q_{i t}=\alpha+\beta_{1} C_{i t}+\beta_{2}$ TECHNOLOGY $i t+\sum \gamma C O N T R O L_{i t}+\sum \delta Y E A R_{i t}+\sum \varphi I N D_{i t}+\varepsilon$, where $\alpha$ represents the constant term, $\beta_{1}, \beta_{2}, \gamma, \delta$, and $\varphi$ are the coefficients of the explanatory variables, $\varepsilon$ is the error term. The sample contains both UK and GER firms. Q stands for the valuation measure Tobin's Q (Q is winsorized at $1 \%$ level and is used in log form), CGQ / CGI stands for the employed governance rating, and CONTROL is a set of control variables (Size is log of total assets, Leverage is total debt to total assets, Growth is 3 years average growth in net sales, free float is number of shares as free float to total shares outstanding, Capital-Intensity is PPE to total assets, Index Membership indicates blue chip firms based on FTSE100 for UK firms and DAX30 for GER firms, UK dummy indicates UK firms). TECHNOLOGY (TECH) is the residuals from cross sectional OLS regressions with the following format: $\mathrm{CGQ}_{i}=\alpha+\beta \mathrm{CGI}_{\mathrm{i}}+\varepsilon$, and represents the incremental usefulness of the CGQ (through superior weighting technology and / or private information) relative to our naïve CGI rating. The regression models contain year- and industry-fixed effects (based on first-digit SIC industry codes), and have standard errors which are heteroskedasticity robust (White, 1980) and one-way clustered at firm level (Gow et al., 2010; Petersen, 2009). Reported values: coefficient (t-stat). *** (**) $(*)$ indicates significance at $1 \%(5 \%)$ $(10 \%)$, two-tailed level. 
Appendix 3 - 4: Basic OLS Model with alternative Firm Value Measure

Panel A. Basic OLS Model with “unadjusted” Tobin's Q

\begin{tabular}{|c|c|c|c|c|c|c|c|c|c|c|}
\hline \multirow{3}{*}{ Independent VAR } & \multirow{3}{*}{$\begin{array}{l}\text { Pred. } \\
\text { Sign }\end{array}$} & \multicolumn{9}{|c|}{ Firm Value Measure: unadjusted Tobin's $\mathbf{O}$ (dependent variable) } \\
\hline & & \multicolumn{3}{|c|}{ UK \& GER Sample (M1-M3) } & \multicolumn{3}{|c|}{ UK Sample (M4-M6) } & \multicolumn{3}{|c|}{ GER Sample (M7-M9) } \\
\hline & & Model 1 & Model 2 & Model 3 & Model 4 & Model 5 & Model 6 & Model 7 & Model 8 & Model 9 \\
\hline CGQ & + & $\begin{array}{l}.002^{*} \\
(1.67)\end{array}$ & & & $\begin{array}{c}.002^{*} \\
(1.71)\end{array}$ & & & $\begin{array}{c}.001 \\
(0.82)\end{array}$ & & \\
\hline CGI & + & & $\begin{array}{l}.002 * * \\
(2.37)\end{array}$ & $\begin{array}{l}.002 * * \\
(2.36)\end{array}$ & & $\begin{array}{l}.003 * * \\
(2.56)\end{array}$ & $\begin{array}{l}.003 * * \\
(2.55)\end{array}$ & & $\begin{array}{l}.003^{*} \\
(1.84)\end{array}$ & $\begin{array}{l}.003 * \\
(1.77)\end{array}$ \\
\hline TECH & + & & & $\begin{array}{l}-.000 \\
(-0.09)\end{array}$ & & & $\begin{array}{l}-.000 \\
(-0.17)\end{array}$ & & & $\begin{array}{l}-.002 \\
(-0.96)\end{array}$ \\
\hline Firm controls & & Yes & Yes & Yes & Yes & Yes & Yes & Yes & Yes & Yes \\
\hline Year fixed effects & & Yes & Yes & Yes & Yes & Yes & Yes & Yes & Yes & Yes \\
\hline Industry fixed effects & & Yes & Yes & Yes & Yes & Yes & Yes & Yes & Yes & Yes \\
\hline Clustered (firm) & & Yes & Yes & Yes & Yes & Yes & Yes & Yes & Yes & Yes \\
\hline Adj. $\mathrm{R}^{2}$ & & .2112 & .2128 & .2124 & .2262 & .2283 & .2278 & .3309 & .3365 & .3362 \\
\hline Sample Size & & 2086 & 2086 & 2086 & 1677 & 1677 & 1677 & 409 & 409 & 409 \\
\hline
\end{tabular}

Panel B. Basic OLS Model with Market-to-Book Ratio

\begin{tabular}{|c|c|c|c|c|c|c|c|c|c|c|}
\hline \multirow{3}{*}{ Independent VAR } & \multirow{3}{*}{$\begin{array}{l}\text { Pred. } \\
\text { Sign }\end{array}$} & \multicolumn{9}{|c|}{ Firm Value Measure: MTB (dependent variable) } \\
\hline & & \multicolumn{3}{|c|}{ UK \& GER Sample (M1-M3) } & \multicolumn{3}{|c|}{ UK Sample (M4-M6) } & \multicolumn{3}{|c|}{ GER Sample (M7-M9) } \\
\hline & & Model 1 & Model 2 & Model 3 & Model 4 & Model 5 & Model 6 & Model 7 & Model 8 & Model 9 \\
\hline CGQ & + & $\begin{array}{c}.003 * * * \\
(3.61)\end{array}$ & & & $\begin{array}{c}.003 * * * \\
(3.19)\end{array}$ & & & $\begin{array}{l}.002^{*} \\
(1.72)\end{array}$ & & \\
\hline CGI & + & & $\begin{array}{c}.003 * * * \\
(5.02)\end{array}$ & $\begin{array}{c}.003 * * * \\
(5.00)\end{array}$ & & $\begin{array}{c}.004 * * * \\
(4.57)\end{array}$ & $\begin{array}{c}.004 * * * \\
(4.56)\end{array}$ & & $\begin{array}{l}.002 * * \\
(2.04)\end{array}$ & $\begin{array}{l}.002 * * \\
(2.04)\end{array}$ \\
\hline TECH & + & & & $\begin{array}{c}-.000 \\
(-0.16)\end{array}$ & & & $\begin{array}{c}-.000 \\
(-0.18)\end{array}$ & & & $\begin{array}{c}.000 \\
(0.12)\end{array}$ \\
\hline Firm controls & & Yes & Yes & Yes & Yes & Yes & Yes & Yes & Yes & Yes \\
\hline Year fixed effects & & Yes & Yes & Yes & Yes & Yes & Yes & Yes & Yes & Yes \\
\hline Industry fixed effects & & Yes & Yes & Yes & Yes & Yes & Yes & Yes & Yes & Yes \\
\hline Clustered (firm) & & Yes & Yes & Yes & Yes & Yes & Yes & Yes & Yes & Yes \\
\hline Adj. $R^{2}$ & & .1797 & .1870 & .1866 & .1486 & .1565 & .1560 & .2850 & .2886 & .2868 \\
\hline Sample Size & & 2086 & 2086 & 2086 & 1677 & 1677 & 1677 & 409 & 409 & 409 \\
\hline
\end{tabular}

Panel C. Basic OLS Model with Market-to-Sales Ratio

\begin{tabular}{|c|c|c|c|c|c|c|c|c|c|c|}
\hline \multirow{3}{*}{ Independent VAR } & \multirow{3}{*}{$\begin{array}{l}\text { Pred. } \\
\text { Sign }\end{array}$} & \multicolumn{9}{|c|}{ Firm Value Measure: MTS (dependent variable) } \\
\hline & & \multicolumn{3}{|c|}{ UK \& GER Sample (M1-M3) } & \multicolumn{3}{|c|}{ UK Sample (M4-M6) } & \multicolumn{3}{|c|}{ GER Sample (M7-M9) } \\
\hline & & Model 1 & Model 2 & Model 3 & Model 4 & Model 5 & Model 6 & Model 7 & Model 8 & Model 9 \\
\hline CGQ & + & $\begin{array}{c}.001 \\
(0.84)\end{array}$ & & & $\begin{array}{c}-.000 \\
(-0.06)\end{array}$ & & & $\begin{array}{c}.004 * * * \\
(2.73)\end{array}$ & & \\
\hline CGI & + & & $\begin{array}{c}.003 * * * \\
(3.03)\end{array}$ & $\begin{array}{c}.003 * * * \\
(2.94)\end{array}$ & & $\begin{array}{l}.002 * \\
(1.66)\end{array}$ & $\begin{array}{c}.002 \\
(1.61)\end{array}$ & & $\begin{array}{c}.006 * * * \\
(3.89)\end{array}$ & $\begin{array}{c}.006 * * * \\
(3.86)\end{array}$ \\
\hline ТЕСН & + & & & $\begin{array}{c}-.003 * * \\
(-2.42)\end{array}$ & & & $\begin{array}{c}-.003 * * \\
(-1.98)\end{array}$ & & & $\begin{array}{c}-.002 \\
(-0.91)\end{array}$ \\
\hline Firm controls & & Yes & Yes & Yes & Yes & Yes & Yes & Yes & Yes & Yes \\
\hline Year fixed effects & & Yes & Yes & Yes & Yes & Yes & Yes & Yes & Yes & Yes \\
\hline Industry fixed effects & & Yes & Yes & Yes & Yes & Yes & Yes & Yes & Yes & Yes \\
\hline Clustered (firm) & & Yes & Yes & Yes & Yes & Yes & Yes & Yes & Yes & Yes \\
\hline Adj. $\mathrm{R}^{2}$ & & .2806 & .2856 & .2879 & .2557 & .2575 & .2597 & .4148 & .4342 & .4341 \\
\hline Sample Size & & 2086 & 2086 & 2086 & 1677 & 1677 & 1677 & 409 & 409 & 409 \\
\hline
\end{tabular}

Notes: The underlying regression models are: $P E R F_{i t}=\alpha+\beta_{1} C G Q_{i t}+\sum \gamma C O N T R O L_{i t}+\sum \delta Y E A R_{i t}$ $+\sum \varphi I N D_{i t}+\varepsilon$, and $Q_{i t}=\alpha+\beta_{1} C G I_{i t}+\beta_{2}$ TECHNOLOGY $i t+\sum \gamma C O N T R O L_{i t}+\sum \delta Y E A R_{i t}+\sum \varphi I N D_{i t}+\varepsilon$, where $\alpha$ represents the constant term, $\beta_{1}, \beta_{2}, \gamma, \delta$, and $\varphi$ are the coefficients of the explanatory variables, $\varepsilon$ is the error term. The sample contains both UK and GER firms. PERF represents different firm value measures. $Q^{*}$, MTB, and MTS. Q* stands for the valuation measure Tobin's Q (unadjusted, i.e., without log transformation and winsorized extreme percentiles), MTB stands for the valuation measure Market-to-Book ratio of equity (MTB is winsorized at $1 \%$ level and is used in $\log$ form), and MTS stands for the valuation measure Market-to-Sales Ratio (MTS is winsorized at 1\% level and is used in log form). CGQ / CGI stands for the employed governance rating, and CONTROL is a set of control variables (Size is log of total assets, Leverage is total debt to total assets, Growth is 3 years average growth in net sales, free float is number of shares as free float to total shares outstanding, Capital-Intensity is PPE to total assets, Index Membership indicates blue chip firms based on FTSE100 for UK firms and DAX30 for GER firms, UK dummy indicates UK firms). TECHNOLOGY (TECH) is the residuals from cross sectional OLS regressions with the following format: $\mathrm{CGQ}_{\mathrm{i}}=\alpha+\beta \mathrm{CGI}_{\mathrm{i}}+\varepsilon$, and represents the incremental usefulness of the CGQ (through superior weighting technology and / or private information) relative to our naïve CGI rating. The regression models contain year- and industry-fixed effects 
(based on first-digit SIC industry codes), and have standard errors which are heteroskedasticity robust (White, 1980) and one-way clustered at firm level (Gow et al., 2010; Petersen, 2009). Reported values: coefficient (tstat). $* * *(* *)(*)$ indicates significance at $1 \%(5 \%)(10 \%)$, two-tailed level. 
Appendix 3 - 5: Basic OLS Model with alternative CGI Score

Panel A. Basic OLS Model with $\mathrm{CGI}_{1}$

\begin{tabular}{|c|c|c|c|c|c|c|c|c|c|c|}
\hline \multirow{3}{*}{ Independent VAR } & \multirow{3}{*}{$\begin{array}{c}\text { Pred. } \\
\text { Sign }\end{array}$} & \multicolumn{9}{|c|}{ Firm Value Measure: Tobin's Q (dependent variable) } \\
\hline & & \multicolumn{3}{|c|}{ UK \& GER Sample (M1-M3) } & \multicolumn{3}{|c|}{ UK Sample (M4-M6) } & \multicolumn{3}{|c|}{ GER Sample (M7-M9) } \\
\hline & & Model 1 & Model 2 & Model 3 & Model 4 & Model 5 & Model 6 & Model 7 & Model 8 & Model 9 \\
\hline CGQ & + & $\begin{array}{c}.001 * * * \\
(3.08)\end{array}$ & & & $\begin{array}{c}.001 * * * \\
(2.97)\end{array}$ & & & $\begin{array}{c}.001 \\
(1.41)\end{array}$ & & \\
\hline $\mathbf{C G I}_{1}$ & + & & $\begin{array}{c}.008 * * * \\
(4.53)\end{array}$ & $\begin{array}{c}.008 * * * \\
(4.52)\end{array}$ & & $\begin{array}{c}.008 * * * \\
(3.85)\end{array}$ & $\begin{array}{c}.008 * * * \\
(3.84)\end{array}$ & & $\begin{array}{c}.009 * * * \\
(3.33)\end{array}$ & $\begin{array}{c}.009 * * * \\
(3.23)\end{array}$ \\
\hline $\mathrm{TECH}_{1}$ & + & & & $\begin{array}{c}-.000 \\
(-0.31)\end{array}$ & & & $\begin{array}{c}-.000 \\
(-0.08)\end{array}$ & & & $\begin{array}{c}-.001 \\
(-1.16)\end{array}$ \\
\hline Firm controls & & Yes & Yes & Yes & Yes & Yes & Yes & Yes & Yes & Yes \\
\hline Year fixed effects & & Yes & Yes & Yes & Yes & Yes & Yes & Yes & Yes & Yes \\
\hline Industry fixed effects & & Yes & Yes & Yes & Yes & Yes & Yes & Yes & Yes & Yes \\
\hline Clustered (firm) & & Yes & Yes & Yes & Yes & Yes & Yes & Yes & Yes & Yes \\
\hline Adj. $\mathrm{R}^{2}$ & & .3162 & .3215 & .3212 & .3180 & .3220 & .3216 & .3699 & .3878 & .3884 \\
\hline Sample Size & & 2086 & 2086 & 2086 & 1677 & 1677 & 1677 & 409 & 409 & 409 \\
\hline
\end{tabular}

Panel B. Basic OLS Model with $\mathrm{CGI}_{2}$

\begin{tabular}{|c|c|c|c|c|c|c|c|c|c|c|}
\hline \multirow{3}{*}{ Independent VAR } & \multirow{3}{*}{$\begin{array}{c}\text { Pred. } \\
\text { Sign }\end{array}$} & \multicolumn{9}{|c|}{ Firm Value Measure: Tobin's Q (dependent variable) } \\
\hline & & \multicolumn{3}{|c|}{ UK \& GER Sample (M1-M3) } & \multicolumn{3}{|c|}{ UK Sample (M4-M6) } & \multicolumn{3}{|c|}{ GER Sample (M7-M9) } \\
\hline & & Model 1 & Model 2 & Model 3 & Model 4 & Model 5 & Model 6 & Model 7 & Model 8 & Model 9 \\
\hline CGQ & + & $\begin{array}{c}.001^{* * * *} \\
(3.08)\end{array}$ & & & $\begin{array}{c}.001 * * * \\
(2.97)\end{array}$ & & & $\begin{array}{c}.001 \\
(1.41)\end{array}$ & & \\
\hline $\mathrm{CGI}_{2}$ & + & & $\begin{array}{c}.036 * * * \\
(4.06)\end{array}$ & $\begin{array}{c}.036 * * * \\
(4.07)\end{array}$ & & $\begin{array}{c}.032 * * * \\
(3.17)\end{array}$ & $\begin{array}{c}.032 * * * \\
(3.19)\end{array}$ & & $\begin{array}{c}.056 * * * \\
(3.48)\end{array}$ & $\begin{array}{c}.055 * * * \\
(3.42)\end{array}$ \\
\hline $\mathrm{TECH}_{2}$ & + & & & $\begin{array}{c}.000 \\
(0.22)\end{array}$ & & & $\begin{array}{c}.001 \\
(0.86)\end{array}$ & & & $\begin{array}{l}-.001 \\
(-1.23)\end{array}$ \\
\hline Firm controls & & Yes & Yes & Yes & Yes & Yes & Yes & Yes & Yes & Yes \\
\hline Year fixed effects & & Yes & Yes & Yes & Yes & Yes & Yes & Yes & Yes & Yes \\
\hline Industry fixed effects & & Yes & Yes & Yes & Yes & Yes & Yes & Yes & Yes & Yes \\
\hline Clustered (firm) & & Yes & Yes & Yes & Yes & Yes & Yes & Yes & Yes & Yes \\
\hline Adj. $\mathrm{R}^{2}$ & & .3162 & .3211 & .3208 & .3180 & .3194 & .3194 & .3699 & .4008 & .4024 \\
\hline Sample Size & & 2086 & 2086 & 2086 & 1677 & 1677 & 1677 & 409 & 409 & 409 \\
\hline
\end{tabular}

Panel C. Basic OLS Model with $\mathrm{CGI}_{3}$

\begin{tabular}{|c|c|c|c|c|c|c|c|c|c|c|}
\hline \multirow{3}{*}{ Independent VAR } & \multirow{3}{*}{$\begin{array}{l}\text { Pred. } \\
\text { Sign }\end{array}$} & \multicolumn{9}{|c|}{ Firm Value Measure: Tobin's Q (dependent variable) } \\
\hline & & \multicolumn{3}{|c|}{ UK \& GER Sample (M1-M3) } & \multicolumn{3}{|c|}{ UK Sample (M4-M6) } & \multicolumn{3}{|c|}{ GER Sample (M7-M9) } \\
\hline & & Model 1 & Model 2 & Model 3 & Model 4 & Model 5 & Model 6 & Model 7 & Model 8 & Model 9 \\
\hline CGQ & + & $\begin{array}{c}.001 * * * \\
(3.08)\end{array}$ & & & $\begin{array}{c}.001 * * * \\
(2.97)\end{array}$ & & & $\begin{array}{c}.001 \\
(1.41)\end{array}$ & & \\
\hline $\mathrm{CGI}_{3}$ & + & & $\begin{array}{c}.028^{* * * *} \\
(4.19)\end{array}$ & $\begin{array}{c}.028 * * * \\
(4.20)\end{array}$ & & $\begin{array}{c}.027 * * * \\
(3.84)\end{array}$ & $\begin{array}{c}.027 * * * \\
(3.86)\end{array}$ & & $\begin{array}{l}.036^{* *} \\
(2.57)\end{array}$ & $\begin{array}{l}.035 * * \\
(2.57)\end{array}$ \\
\hline $\mathrm{TECH}_{3}$ & + & & & $\begin{array}{c}.000 \\
(0.74) \\
\end{array}$ & & & $\begin{array}{c}.001 \\
(1.16) \\
\end{array}$ & & & $\begin{array}{c}-.001 \\
(-0.74)\end{array}$ \\
\hline Firm controls & & Yes & Yes & Yes & Yes & Yes & Yes & Yes & Yes & Yes \\
\hline Year fixed effects & & Yes & Yes & Yes & Yes & Yes & Yes & Yes & Yes & Yes \\
\hline Industry fixed effects & & Yes & Yes & Yes & Yes & Yes & Yes & Yes & Yes & Yes \\
\hline Clustered (firm) & & Yes & Yes & Yes & Yes & Yes & Yes & Yes & Yes & Yes \\
\hline Adj. $\mathrm{R}^{2}$ & & .3162 & .3220 & .3219 & .3180 & .3209 & .3213 & .3699 & .3966 & .3962 \\
\hline Sample Size & & 2086 & 2086 & 2086 & 1677 & 1677 & 1677 & 409 & 409 & 409 \\
\hline
\end{tabular}

Notes: The underlying regression models are: $Q_{i t}=\alpha+\beta_{1} C G Q_{i t}+\sum \gamma C O N T R O L_{i t}+\sum \delta Y E A R_{i t}+\sum \varphi I N D_{i t}+\varepsilon$, and $Q_{i t}=\alpha+\beta_{1} C G I_{i t}+\beta_{2}$ TECHNOLOGY $_{i t}+\sum \gamma$ CONTROL $_{i t}+\sum \delta Y E A R_{i t}+\sum \varphi I N D_{i t}+\varepsilon$, where $\alpha$ represents the constant term, $\beta_{1}, \beta_{2}, \gamma, \delta$, and $\varphi$ are the coefficients of the explanatory variables, $\varepsilon$ is the error term. The sample contains both UK and GER firms. Q stands for the valuation measure Tobin's Q (Q is winsorized at $1 \%$ level and is used in log form).CGQ / CGI (as $\mathrm{CGI}_{1} / \mathrm{CGI}_{1} / \mathrm{CGI}_{1}$ ) stands for the employed governance rating. CGI is a relative $\mathrm{CG}$ rating which measures on a yearly base the firm's governance quality with respect to the firm's compliance with the underlying ISS CGQ rating criteria. $\mathrm{CGI}_{2}$ is a $\mathrm{CG}$ rating which is estimated on six CGI subratings (board, audit, charter, compensation, progressive practice, and director ownership) via Principal Component Analysis. $\mathrm{CGI}_{3}$ is a CG rating which is estimated directly on all 47 / 41 ISS CGQ rating criteria via Principal Component Analysis. CONTROL is a set of control variables (Size is log of total assets, Leverage is total debt to total assets, Growth is 3 years average growth in net sales, free float is number of shares as free float to total shares outstanding, Capital-Intensity is PPE to total assets, Index Membership indicates blue chip firms based on FTSE100 for UK firms and DAX30 for GER firms, UK dummy indicates UK firms). TECHNOLOGY $(\mathrm{TECH})$ is the residuals from cross sectional OLS regressions with the following format: $\mathrm{CGQ}_{i}=\alpha+\beta C G \mathrm{I}_{i}+\varepsilon$, and represents the incremental usefulness of the CGQ (through superior weighting technology and / or private 
information) relative to our naïve CGI rating. The regression models contain year- and industry-fixed effects (based on first-digit SIC industry codes), and have standard errors which are heteroskedasticity robust (White, 1980) and one-way clustered at firm level (Gow et al., 2010; Petersen, 2009). Reported values: coefficient (tstat). $* * *(* *)(*)$ indicates significance at $1 \%(5 \%)(10 \%)$, two-tailed level. 
Appendix 3 - 6: Basic OLS Model with additional Control Variables

Panel A. Basic OLS Model with an extended set of control variables

\begin{tabular}{|c|c|c|c|c|c|c|c|c|c|c|}
\hline \multirow{3}{*}{ Independent VAR } & \multirow{3}{*}{$\begin{array}{l}\text { Pred. } \\
\text { Sign }\end{array}$} & \multicolumn{9}{|c|}{ Firm Value Measure: Tobin's Q (dependent variable) } \\
\hline & & \multicolumn{3}{|c|}{ UK \& GER Sample (M1-M3) } & \multicolumn{3}{|c|}{ UK Sample (M4-M6) } & \multicolumn{3}{|c|}{ GER Sample (M7-M9) } \\
\hline & & Model 1 & Model 2 & Model 3 & Model 4 & Model 5 & Model 6 & Model 7 & Model 8 & Model 9 \\
\hline CGQ & + & $\begin{array}{l}.001^{* *} \\
(2.58)\end{array}$ & & & $\begin{array}{l}.001^{* *} \\
(2.15)\end{array}$ & & & $\begin{array}{c}.001 \\
(1.63)\end{array}$ & & \\
\hline CGI & + & & $\begin{array}{c}.002^{* * *} \\
(4.34)\end{array}$ & $\begin{array}{c}.002 * * * \\
(4.26)\end{array}$ & & $\begin{array}{c}.003 * * * * \\
(3.60)\end{array}$ & $\begin{array}{c}.003^{* * *} \\
(3.54)\end{array}$ & & $\begin{array}{l}.001^{*} \\
(1.69)\end{array}$ & $\begin{array}{l}.001^{*} \\
(1.74)\end{array}$ \\
\hline ТЕCH & + & & & $\begin{array}{c}-.000 \\
(-0.55)\end{array}$ & & & $\begin{array}{c}-.001 \\
(-0.67)\end{array}$ & & & $\begin{array}{c}.000 \\
(0.18)\end{array}$ \\
\hline Firm controls (extended s & & Yes & Yes & Yes & Yes & Yes & Yes & Yes & Yes & Yes \\
\hline Year fixed effects & & Yes & Yes & Yes & Yes & Yes & Yes & Yes & Yes & Yes \\
\hline Industry fixed effects & & Yes & Yes & Yes & Yes & Yes & Yes & Yes & Yes & Yes \\
\hline Clustered (firm) & & Yes & Yes & Yes & Yes & Yes & Yes & Yes & Yes & Yes \\
\hline Adj. $R^{2}$ & & .4468 & .4571 & .4567 & .4101 & .4239 & .4235 & .5590 & .5615 & .5594 \\
\hline Sample Size & & 832 & 832 & 832 & 597 & 597 & 597 & 235 & 235 & 235 \\
\hline
\end{tabular}

Panel B. Basic OLS Model with selected (stepwise) control variables

\begin{tabular}{|c|c|c|c|c|c|c|c|c|c|c|}
\hline \multirow{3}{*}{ Independent VAR } & \multirow{3}{*}{$\begin{array}{c}\text { Pred. } \\
\text { Sign }\end{array}$} & \multicolumn{9}{|c|}{ Firm Value Measure: Tobin's Q (dependent variable) } \\
\hline & & \multicolumn{3}{|c|}{ UK \& GER Sample (M1-M3) } & \multicolumn{3}{|c|}{ UK Sample (M4-M6) } & \multicolumn{3}{|c|}{ GER Sample (M7-M9) } \\
\hline & & Model 1 & Model 2 & Model 3 & Model 4 & Model 5 & Model 6 & Model 7 & Model 8 & Model 9 \\
\hline CGQ & + & $\begin{array}{l}.001^{* *} \\
(2.54)\end{array}$ & & & $\begin{array}{l}.002 * * \\
(2.36)\end{array}$ & & & $\begin{array}{c}.001 \\
(1.22)\end{array}$ & & \\
\hline CGI & + & & $\begin{array}{c}.002 * * * \\
(4.19)\end{array}$ & $\begin{array}{c}.002 * * * \\
(4.09)\end{array}$ & & $\begin{array}{c}.003 * * * \\
(3.87)\end{array}$ & $\begin{array}{c}.003 * * * \\
(3.79)\end{array}$ & & $\begin{array}{l}.001 * * \\
(2.02)\end{array}$ & $\begin{array}{l}.001 * * \\
(2.00)\end{array}$ \\
\hline ТЕСН & + & & & $\begin{array}{l}-.000 \\
(-0.64)\end{array}$ & & & $\begin{array}{c}-.001 \\
(-0.59)\end{array}$ & & & $\begin{array}{l}-.000 \\
(-0.43)\end{array}$ \\
\hline Firm controls (selected sc & & Yes & Yes & Yes & Yes & Yes & Yes & Yes & Yes & Yes \\
\hline Year fixed effects & & Yes & Yes & Yes & Yes & Yes & Yes & Yes & Yes & Yes \\
\hline Industry fixed effects & & Yes & Yes & Yes & Yes & Yes & Yes & Yes & Yes & Yes \\
\hline Clustered (firm) & & Yes & Yes & Yes & Yes & Yes & Yes & Yes & Yes & Yes \\
\hline Adj. $R^{2}$ & & .4481 & .4579 & .4576 & .4082 & .4237 & .4232 & .4640 & .4697 & .4685 \\
\hline Sample Size & & 888 & 888 & 888 & 618 & 618 & 618 & 354 & 354 & 354 \\
\hline
\end{tabular}

Notes: The underlying regression models are: $Q_{i t}=\alpha+\beta_{1} C G Q_{i t}+\sum \gamma C O N T R O L_{i t}+\sum \delta Y E A R_{i t}+\sum \varphi I N D_{i t}+\varepsilon$, and $Q_{i t}=\alpha+\beta_{1} C G I_{i t}+\beta_{2}$ TECHNOLOGY $_{i t}+\sum \gamma$ CONTROL $_{i t}+\sum \delta Y E A R_{i t}+\sum \varphi I N D_{i t}+\varepsilon$, where $\alpha$ represents the constant term, $\beta_{1}, \beta_{2}, \gamma, \delta$, and $\varphi$ are the coefficients of the explanatory variables, $\varepsilon$ is the error term. The sample contains both UK and GER firms. Q stands for the valuation measure Tobin's Q (Q is winsorized at 1\% level and is used in log form).CGQ / CGI stands for the employed governance rating. For Panel A, CONTROL is an extended set of control variables (Size is log of total assets, Leverage is total debt to total assets, Growth is 3 years average growth in net sales, Freefloat is number of shares as free float to total shares outstanding, CapitalIntensity is PPE to total assets, Index Membership indicates blue chip firms based on FTSE100 for UK firms and DAX30 for GER firms, UK dummy indicates UK firms - if applicable, log of firm age based on date of incorporation for UK firms and company founded date for GER firms, risk as yearly average standard deviation based on monthly stock returns, R\&D expenditures to total assets, capital expenditures to total assets, cash from operations to total assets, current and past ROA, loss as indicator variable of negative net income, IFRS / USGAAP as indicator variables of respective accounting standard application). For Panel B, CONTROL is a selective set of control variables which are selected by four versions of stepwise regression technique separately for each of the three sample compositions. (1) Combined UK and GER sample controls: size is log of total assets, Growth is 3 years average growth in net sales, Capital-Intensity is PPE to total assets, Index Membership indicates blue chip firms based on FTSE100 for UK firms and DAX30 for GER firms, UK dummy indicates UK firms, R\&D expenditures to total assets, cash to total assets, current and past ROA. (2) UK sample controls: size is $\log$ of total assets, Growth is 3 years average growth in net sales, Freefloat is number of shares as free float to total shares outstanding, Capital-Intensity is PPE to total assets, Index Membership indicates blue chip firms based on FTSE100 for UK firms and DAX30 for GER firms, R\&D expenditures to total assets, cash to total assets, current and past ROA. (3) German sample controls: Capital-Intensity is PPE to total assets, current and past ROA, Leverage is total debt to total assets, Growth is 3 years average growth in net sales, Freefloat is number of shares as free float to total shares outstanding, and cash from operations to total assets. TECHNOLOGY (TECH) is the residuals from cross sectional OLS regressions with the following format: CGQ $=\alpha+\beta \mathrm{CGI}_{\mathrm{i}}+\varepsilon$, and represents the incremental usefulness of the CGQ (through superior weighting technology and/or private information) relative to our naïve CGI rating. The regression models contain year and industryfixed effects (based on first-digit SIC industry codes), and have standard errors which are heteroskedasticity 
robust (White, 1980) and one-way clustered at firm level (Gow et al., 2010; Petersen, 2009). Reported values: coefficient (t-stat). ${ }^{* * *}(* *)(*)$ indicates significance at $1 \%(5 \%)(10 \%)$, two-tailed level. 
Appendix 3 - 7: Economic Significance

Panel A. Economic significance for combined UK \& GER sample

\begin{tabular}{lcccc}
\hline Variables & $\begin{array}{c}\text { Effect of one- } \\
\text { percent change on } \\
Q\end{array}$ & $\begin{array}{c}\text { Effect of one-sigma } \\
\text { change on } Q\end{array}$ & $\begin{array}{c}\text { Effect of min-max } \\
\text { change on } Q\end{array}$ & $\begin{array}{c}\text { Additional variance } \\
\text { explained }\end{array}$ \\
\hline CGQ & $0.12 \%$ & $3.39 \%$ & $11.67 \%$ & - \\
CGI & $0.16 \%$ & $4.72 \%$ & $16.27 \%$ & $1.43 \%$ \\
\hline
\end{tabular}

Panel B. Economic significance for UK sample

\begin{tabular}{lcccc}
\hline Variables & $\begin{array}{c}\text { Effect of one- } \\
\text { percent change on } \\
Q\end{array}$ & $\begin{array}{c}\text { Effect of one-sigma } \\
\text { change on } Q\end{array}$ & $\begin{array}{c}\text { Effect of min-max } \\
\text { change on } Q\end{array}$ & $\begin{array}{c}\text { Additional variance } \\
\text { explained }\end{array}$ \\
\hline CGQ & $0.13 \%$ & $3.76 \%$ & $12.97 \%$ & - \\
CGI & $0.19 \%$ & $5.34 \%$ & $18.54 \%$ & $1.71 \%$ \\
\hline
\end{tabular}

Panel C. Economic significance for GER sample

\begin{tabular}{lcccc}
\hline Variables & $\begin{array}{c}\text { Effect of one- } \\
\text { percent change on } \\
Q\end{array}$ & $\begin{array}{c}\text { Effect of one-sigma } \\
\text { change on } Q\end{array}$ & $\begin{array}{c}\text { Effect of min-max } \\
\text { change on } Q\end{array}$ & $\begin{array}{c}\text { Additional variance } \\
\text { explained }\end{array}$ \\
\hline CGQ & $0.09 \%$ & $2.64 \%$ & $8.87 \%$ & - \\
CGI & $0.15 \%$ & $4.45 \%$ & $14.86 \%$ & $2.00 \%$ \\
\hline
\end{tabular}

Notes: Q is Tobin's Q. CGQ stands for ISS's Corporate Governance Quotient and CGI stands for our naïve corporate governance rating based on the raw dataset of the CGQ rating. Effect of one-percent-change, for example, stands for the valuation effect which results from one percent change of the governance variable in the valuation variable. The additional variance explained equals the decrease or increase of explained sum of squares to total sum of squares when installing the CGI instead of the CGQ rating. 
Appendix 3 - 8: GOV Ratings and CGQ Subcategories

Panel A. UK sample (CGQ rating)

\begin{tabular}{lcccccc}
\hline \multicolumn{7}{c}{ Dependent Variable: CGQ Rating } \\
\hline Board & $\mathbf{2 0 0 3}$ & $\mathbf{2 0 0 4}$ & $\mathbf{2 0 0 5}$ & $\mathbf{2 0 0 6}$ & $\mathbf{2 0 0 7}$ & Panel \\
Audit & $.5248^{* * *}$ & $.4917^{* * *}$ & $.4927^{* * *}$ & $.4300^{* * *}$ & $.4049^{* * *}$ & $.4708^{* * *}$ \\
Charter & $.3554^{* * *}$ & $.2963^{* * *}$ & $.2036^{* * *}$ & $.2501^{* * *}$ & $.2494^{* * *}$ & $.2585^{* * *}$ \\
Compensation & $.1910^{* * *}$ & $-.0380^{* * *}$ & $.1286^{* * *}$ & $.2599^{* * *}$ & $-.0167^{* *}$ & .0056 \\
Prog. Practice & $.1255^{* * *}$ & $.2213^{* * *}$ & $.2934^{* * *}$ & $.2733^{* * *}$ & $.2617^{* * *}$ & $.2562^{* * *}$ \\
Ownership & $.1041^{* * *}$ & $.0824^{*}$ & $.1772^{* * *}$ & $.1102^{* * *}$ & $.1777^{* * *}$ & $.1346^{* * *}$ \\
\hline Year fe & $.1887^{* * *}$ & $.1553^{* * *}$ & $.2154^{* * *}$ & $.1931^{* * *}$ & $.2463^{* * *}$ & $.2030^{* * *}$ \\
$\mathrm{R}^{2}$ & No & No & No & No & No & Yes \\
Sample Size & .7455 & .6909 & .7087 & .6178 & .5629 & .6098 \\
\hline
\end{tabular}

Panel B. UK sample (CGI rating)

\begin{tabular}{|c|c|c|c|c|c|c|}
\hline & \multicolumn{6}{|c|}{ Dependent Variable: CGI Rating } \\
\hline & 2003 & 2004 & 2005 & 2006 & 2007 & Panel \\
\hline Board & $.5537 * * *$ & $.4785 * * *$ & $.4712 * * *$ & $.5190 * * *$ & $.4907 * * *$ & $.5002 * * *$ \\
\hline Audit & $.2262 * * *$ & $.1392 * * *$ & $.2559 * * *$ & $.2815 * * *$ & $.3243 * * *$ & $.2737 * * *$ \\
\hline Charter & $.0638 * * *$ & $-.0212 * * *$ & $.0292 * * *$ & $.0707 * * *$ & $.0434 * * *$ & $.0179^{*}$ \\
\hline Compensation & $.4167 * * *$ & $.2763 * * *$ & $.2543 * * *$ & $.3274 * * *$ & $.2677 * * *$ & $.2983 * * *$ \\
\hline Prog. Practice & $.2067 * * *$ & $.3877 * * *$ & $.4059 * * *$ & $.3220 * * *$ & $.3413 * * *$ & $.3442 * * *$ \\
\hline Ownership & $.3196 * * *$ & $.2540 * * *$ & $.2697 * * *$ & $.3079 * * *$ & $.3283 * * *$ & $.2979 * * *$ \\
\hline Year fe & No & No & No & No & No & Yes \\
\hline $\mathrm{R}^{2}$ & .9290 & .9649 & .9644 & .9438 & .9423 & .9419 \\
\hline Sample Size & 190 & 195 & 499 & 482 & 432 & 1798 \\
\hline
\end{tabular}

Panel C. GER sample (CGQ rating)

\begin{tabular}{lcccccc}
\hline \multicolumn{7}{c}{ Dependent Variable: CGQ Rating } \\
\hline Board & $\mathbf{2 0 0 3}$ & $\mathbf{2 0 0 4}$ & $\mathbf{2 0 0 5}$ & $\mathbf{2 0 0 6}$ & $\mathbf{2 0 0 7}$ & Panel \\
Audit & $.2698^{* * *}$ & $.3951^{* * *}$ & $.5717^{* * *}$ & $.4852^{* * *}$ & $.2580^{* * *}$ & $.3927^{* * *}$ \\
Charter & -.0191 & -.0755 & $.1634^{* *}$ & $.1429^{* * *}$ & $.1028^{* *}$ & $.0828^{* * *}$ \\
Compensation & $.2102^{* * *}$ & .0663 & -.1078 & $.0817^{* * *}$ & .0395 & .0419 \\
Prog. Practice & $.6374 * * *$ & $.5759^{* * *}$ & $.4648^{* * *}$ & $.5218^{* * *}$ & $.4028^{* * *}$ & $.5150^{* * *}$ \\
Ownership & $.1339^{*}$ & .1299 & -.0610 & .0862 & $.2021^{* *}$ & $.1326^{* * *}$ \\
\hline Year fe & $.2408^{* * *}$ & -.0117 & -.0448 & .0110 & $.1644^{*}$ & $.0603^{*}$ \\
$\mathrm{R}^{2}$ & No & No & No & No & No & Yes \\
Sample Size & .6788 & .7860 & .6201 & .6287 & .4226 & .5793 \\
\hline
\end{tabular}

Panel D. GER sample (CGI rating)

\begin{tabular}{lcccccc}
\hline \multicolumn{7}{c}{ Dependent Variable: CGI Rating } \\
\hline Board & $\mathbf{2 0 0 3}$ & $\mathbf{2 0 0 4}$ & $\mathbf{2 0 0 5}$ & $\mathbf{2 0 0 6}$ & $\mathbf{2 0 0 7}$ & Panel \\
Audit & $.3622^{* * *}$ & $.4330^{* * *}$ & $.4498^{* * *}$ & $.5456^{* * *}$ & $.4059^{* * *}$ & $.4298^{* * *}$ \\
Charter & $.2619^{* * *}$ & $.1024 * * *$ & $.1796^{* * *}$ & $.1322^{* * *}$ & $.0730^{*}$ & $.1639^{* * *}$ \\
Compensation & $.1633^{* * *}$ & $.0562^{*}$ & $.0770^{* *}$ & $.0133^{* * *}$ & -.0071 & $.0609^{* * *}$ \\
Prog. Practice & $.7060^{* * *}$ & $.5873^{* * *}$ & $.4564^{* * *}$ & $.3418^{* * *}$ & $.6247^{* * *}$ & $.5417^{* * *}$ \\
Ownership & $.1188^{*}$ & $.2505^{* * *}$ & $.2328^{* * *}$ & $.3143^{* * *}$ & $.2115^{* * *}$ & $.2229^{* * *}$ \\
\hline Year fe & $.2393^{* * *}$ & $.1468^{* * *}$ & $.2410^{* * *}$ & $.2408^{* * *}$ & $.3045^{* * *}$ & $.2426^{* * *}$ \\
$\mathrm{R}^{2}$ & No & No & No & No & No & Yes \\
Sample Size & .8707 & .9700 & .9228 & .9597 & .9356 & .8949 \\
\hline
\end{tabular}

Notes: The underlying regression model is: $G_{O} O V_{i t}=\alpha+\sum \gamma C G Q$ subcategories $_{i t}+\varepsilon$, where $\alpha$ represents the constant term, $\sum \gamma$ are the coefficients of the explanatory variables, $\varepsilon$ is the error term. The sample contains either UK (Panel A and B) or GER firms (Panel C and D). GOV stands for the employed governance rating (either CGQ or CGI). CGQsubcategories are equally weighted measures of board, audit, charter, compensation, progressive practice, and ownership based on the respective CGQ provisions depicted in Table $3-2$. The regression models contain year-fixed effects (as indicated with 'year fe'), and have standard errors which are 
heteroskedasticity robust (White, 1980). Reported values: standardized (beta) coefficient (t-stat). *** $(* *)(*)$ indicates significance at $1 \%(5 \%)(10 \%)$, two-tailed level. 


\title{
4. DO CORPORATE GOVERNANCE ANALYSTS MATTER? EVIDENCE FROM A QUASI-NATURAL EXPERIMENT
}

\author{
Nico Lehmann ${ }^{76}$
}

Working Paper ${ }^{77}$, Georg-August-Universität Göttingen

\begin{abstract}
This paper sheds light on the economic consequences of governance analyst coverage. Specifically, it focuses on two different groups (financial analysts and investors) as well as on two firm-level mechanisms (corporate governance quality and earnings management) which might be affected by the presence of governance analysts. Using an exogenous shock in governance analyst coverage in the UK, I find that an increase in governance analyst coverage results (1) in increasing financial analyst following, (2) weakly in increasing free float, (3) in improvements of firm-level corporate governance, and (4) weakly in decreasing accruals manipulations. In line with the paper's predictions, these findings suggest that financial analysts, investors, and managers respond to changes in governance analyst coverage. Specifically, they imply that financial analysts and investors potentially consider governance information provided by governance analysts when preparing analyst reports or setting investment strategies, respectively. They further indicate that managers and directors feel potentially pressured by the presence of governance analysts to improve governance quality, if necessary. Overall, my findings are consistent with the notion that governance analysts represent economically meaningful information intermediaries who enhance the firm's information environment and promote external monitoring to managers.
\end{abstract}

JEL Classification: G24, G30, M41

Keywords: Information intermediaries, corporate governance analysts, earnings management

Acknowledgments: For valuable comments, I am grateful to Jörg-Markus Hitz (dissertation adviser), Tim Adam, Ulf Brüggemann, Hans B. Christensen, Joachim Gassen, Liang Hao (discussant), Urska Kosi, William P. Rees, Hollis Skaife, David Veenman, and participants at the Humboldt Summer School of 'Empirical Financial Accounting Research' in Berlin, Germany (August 2013), the 10th Workshop on 'Corporate Governance' in Brussels, Belgium (October 2013), the accounting research workshop at HU Berlin, Germany (May 2014), the Annual Meeting of the European Accounting Association in Tallinn, Estonia (May 2014), and the Annual Meeting of the European Financial Management Association in Rome, Italy (June 2014). I also thank Paul Wanner and Kristof Ho Tiu (both, ISS Governance Services, formerly RiskMetrics Group) for providing the CGQ data.

\footnotetext{
${ }^{76}$ Georg-August-Universität Göttingen, Faculty of Economic Sciences, Chair of Accounting and Auditing, Platz der Göttinger Sieben 3, 37073 Göttingen, Germany.

77 The working paper is available at SSRN (http://papers.ssrn.com/sol3/papers.cfm?abstract_id=2437321, last accessed June 30, 2014). First version of the working paper: July 2013. This version: July 2014.
} 


\subsection{Introduction}

Using a quasi-natural experiment, this paper investigates potential economic consequences of governance analyst coverage. Similar to financial analysts or the business press, governance analysts represent information intermediaries on capital markets. From an economic perspective, information intermediaries process, enhance, and disseminate information to capital market participants in order to alleviate transaction costs (Healy and Palepu, 2002). The core business of governance analysts consists of governance consultancy and risk assessments via, e.g., commercial corporate governance ratings or proxy voting recommendations to institutional shareholders or other capital market participants. To the extent that governance analysts are able to reduce the capital market participants' costs of making informed decisions (i.e., transaction costs), e.g., by providing more accurate or less expensive evaluations of governance quality, information provided by these analysts is valuable for capital market participants (Ertimur et al., 2013; Hitz and Lehmann, 2013).

Prior literature on analysts has primarily focused on the role of sell-side equity analysts examining, among other things, the determinants and consequences of financial analyst coverage (e.g., Yu, 2008; Jiraporn et al., 2012a; Degeorge et al., 2013a; Irani and Oesch, 2013; Chen et al., 2013). Although this has contributed much to our understanding of financial analysts, so far only little attention has been paid to the role of 'other' types of analysts and their interactions with, for example, sell-side equity analysts. In a recent related literature survey, Beyer et al. (2010, p. 336) pose that "other information intermediaries [like, e.g., rating agencies and debt analysts] are important in understanding the development of the overall corporate information environment" and that "more research in this area is warranted".

Besides having first empirical evidence on buy-side analysts and bond analysts (Cheng et al., 2006; De Franco et al., 2009), as well as on the (non-financial) information processing of financial analysts (Orens and Lybaert, 2010; Bhat et al., 2006; Byard et al., 2006; Asare et al., 2011), previous literature has been silent on the actual role of governance analysts as information intermediaries and their potential interactions with financial analysts, investors, or managers. This is surprising given the increasing importance and popularity of proxy voting advisory and commercial corporate governance ratings among capital market participants (Larcker et al., 2013; Daines et al., 2010). Accordingly, the main purpose of this study is to fill this research gap and to shed light on the role and relevance of non-financial corporate governance analysts. To that end, this paper examines potential economic 
consequences of governance analyst coverage. To glean first empirical insights into the coverage effects of governance analysts, I focus on two different groups as well as on two firm-level mechanisms which are potentially affected by the presence of governance analysts: (1) financial analysts, (2) investors, (3) corporate governance quality, and (4) earnings management.

Based on data from Institutional Shareholder Services (ISS), I measure governance analysts' coverage on the dimension of whether or not ISS provides governance reports and commercial corporate governance ratings (CGQ ratings). Similar to financial analysts, the decision of ISS analysts to cover a firm depends on firm characteristics, i.e., index membership and institutional ownership, and is thus endogenous in nature (e.g., Irani and Oesch, 2013, p. 399). As these firm characteristics are in turn most likely related to my outcome variables, i.e., analyst following, free float, governance quality, and accounting quality, ordinary OLS results will be potentially biased.

To address these concerns, I exploit an exogenous shock to the coverage by ISS corporate governance analysts. From 2004 to 2005, ISS coverage in the UK exhibited an unusual and strong increase of almost $154 \%$. A similar shock is not observable in any of the other countries ISS operated in at that time. In 2005, ISS together with FTSE developed different governance-related stock indices, with one of them explicitly focusing on UK firms. To construct the UK specific stock index with a sufficient firm base, ISS decided to enlarge the UK coverage in 2005 from 209 to 530 firms. From an econometrician's perspective, the observed increase in UK ISS coverage is exogenously caused by the joint stock indices project, and not endogenously determined by a change of certain firm characteristics like institutional ownership structure or index membership. Thus, by exploiting the exogenous shock setting as a quasi-natural experiment, the UK sample provides a useful setting to investigate the effects of ISS governance analyst coverage as well as to draw causal inferences.

Employing a twofold difference-in-difference research design with one treatment and two natural control groups, I find evidence that the exogenous increase in ISS analyst coverage results (1) in increasing analyst following, (2) weakly in increasing free float, (3) in improvements of firm-level corporate governance, and (4) weakly in decreasing accruals manipulations. These findings are robust to endogeneity concerns. Consistent with the paper's predictions, they suggest that financial analysts, investors, and managers respond to changes 
in governance analyst coverage. Specifically, the findings imply that financial analysts and investors potentially consider governance information provided by governance analysts when preparing analyst reports or setting investment strategies, respectively. Moreover, they further indicate that both, financial analysts and investors, are potentially able to reduce their costs of making informed decisions when relying on information provided by governance analysts. In addition, the findings also suggest that managers and directors feel potentially pressured by the presence of governance analysts to improve governance quality, if necessary. Overall, the paper's findings are consistent with the notion that governance analysts represent economically important information intermediaries who enhance the firm's information environment and promote external monitoring to managers.

Taken together, the findings of this paper contribute to the extant literature in several ways. First, this is to my knowledge the first paper to provide evidence on the coverage effects of corporate governance analysts. In doing so, it extends research on analysts by introducing 'another' type of analysts, i.e., non-financial corporate governance analysts, and by providing evidence on the interrelations of governance analysts and financial analysts.

By investigating the role of governance analysts as information intermediaries, my paper additionally contributes to at least two related streams of literature; the literature on commercial corporate governance ratings and proxy voting advisory, and the literature on the governance role of institutional investors. The former stream of literature addresses issues like the growth and impact of commercial corporate governance rating vendors (e.g., Rose, 2007), the role and regulation as well as the usefulness of proxy advisors (e.g., Ertimur et al., 2013; Larcker et al., 2013), or the usefulness of commercial corporate governance ratings to investors (e.g., Daines et al., 2010; Hitz and Lehmann, 2013). The majority of prior findings on the question of whether proxy advisors or governance rating vendors are valuable for investors, however, does not provide evidence in favor of the governance industry (e.g., Daines et al., 2010). Thus, the economic vindication of these information intermediaries is still a question of debate. Extending this stream of literature, evidence on the coverage effects of governance analysts provides additional insights into the usefulness of governance advisory on capital markets.

Prior research on the governance role of institutional investors, for example, investigates whether these investors shape the firm's reporting behavior (e.g., Chung et al., 2002) or whether they enhance the firm's overall corporate governance structure (e.g., 
Aggarwal et al., 2011). Since governance agencies are primarily paid by institutional investors, e.g., mutual funds or public pension funds, in order to enhance the firm's informational environment with respect to governance issues, my paper adds to this research by providing evidence on a potential channel in which the presence of such investors might affect the firm's information environment.

The remainder of the paper is organized as follows. In section 4.2, I provide background information pertaining to the corporate governance business. Section 4.3 presents the paper's empirical predictions. Section 4.4 introduces the identification strategy and describes the empirical setup. In Section 4.5, I present empirical findings and discuss potential implications and additional tests. The last section concludes.

\subsection{Background}

Similar to financial analysts or the business press, governance rating vendors and proxy advisors represent information intermediaries on capital markets. From an economic perspective, information intermediaries "reduce transaction costs in the capital market by providing specialized services and gathering and disseminating information" (Healy and Palepu, 2002, p. 4). To the extent that governance advisors are able to reduce transaction costs, e.g., by providing more accurate or less expensive evaluations of governance quality, information provided by these advisors is valuable for capital market participants (Hitz and Lehmann, 2013). In a similar vein but based on a specific setting of 'say on pay' proxy voting recommendations, Ertimur et al. (2013, p. 5) describe the economic role of proxy advisors as information intermediaries which process and organize "a substantial amount of executive pay information for institutional investors, reducing their cost of making informed decisions".

Three prominent governance rating agencies exist internationally: Institutional Shareholder Services (ISS), Governance Metrics International (GMI), and The Corporate Library (TCL) (e.g., Larcker and Tayan, 2011, p. 437). ${ }^{78}$ In terms of worldwide coverage, ISS is "the most visible governance rating" vendor (Daines et al., 2010, p. 440). It markets

\footnotetext{
${ }^{78}$ Based on 600 underlying governance provisions (and seven overall governance categories), GMI provides a scoring between one to ten and covers almost 3,400 U.S. and wide range of international firms (Derwall and Verwijmeren, 2007). The TCL rating covers over 2,000 U.S. companies and provides letter scoring ranging from A to F by using 120 variables based on six categories. In 2010, GMI and TCL announced their merger, and have since then combined their products and services (Marketwire, 2010). Audit Integrity, who provided Accounting and Governance Risk ratings, is also a part of GMI Ratings. In addition to ISS, GMI, TCL, S\&P provides - since 2007 - the Standard \& Poor's Governance, Accountability, Management Metrics \& Analysis' (GAMMA) score, which also picks up - besides governance issues - risk and strategy issues (S\&P, 2008).
} 
commercial corporate governance ratings for more than 8,000 firms across 31 countries since $2002 .{ }^{79}$ These commercial corporate governance ratings - based on over 60 single governance provisions - are commonly available to institutional shareholders or other capital market participants via subscription packages which can result in fees of up to $\$ 100,000$ per year (Coffin and Collinson, 2005, p. 3). In addition, ISS provides proxy advisory services, i.e., governance-related advisory on how to vote on annual general meetings, for over 1,700 institutional investors managing \$26 trillion in assets, including 24 of the top 25 mutual funds, 25 of the top 25 assets managers, and 17 of the top 25 public pension funds (Daines et al., 2010, p. 439). However, the fact that governance advisors like ISS also provide governance advisory directly to firms raises concerns about their independence (e.g., Koeng and Ueng, 2007, p. 61; Rose, 2007, pp. 891, 906; Vo, 2008, p. 17). In two recent initiatives, the European Securities and Markets Authority (2012) and the European Commission (2011, p. 15) have shared these concerns outlining potential conflicts of interest in situations "when proxy advisors also act as corporate governance consultants to investee companies".

In comparison to the most visible and researched analyst group, namely sell-side equity analysts, governance analysts working for governance rating vendors and proxy voting advisors are different on several dimensions. They sell different products, deal with a different market structure (only few global governance rating vendors operating on an effectively unregulated playing field), have different conflicts of interest (e.g., institutional investors or other capital market participants hire and pay these analysts but firms are directly consulted by them as well), and are rather less involved in direct dealing with firms' management (e.g., at analyst conferences or during conference calls). Nevertheless, executives and directors perceive both analyst groups as influential. A recent survey based on more than 1,000 directors serving on U.S. boards, for example, suggests that survey participants perceive governance advisors like ISS as the third most important group influencing their boards, after (1) institutional investors and (2) financial analysts, and followed by (4) plaintiff's bar, (5) the media, and (6) activist hedge funds (CBM PwC, 2008).

\subsection{Empirical Predictions}

To shed light on the role of governance analysts and their relevance to the capital market, I

\footnotetext{
${ }^{79}$ ISS revised its rating (CGQ) in 2010 and introduced the Governance Risk Indicator (GRId). However, in most points the CGQ is not materially different to its successor the GRId rating (Larcker and Tayan, 2011, p. 440).
} 
investigate potential economic consequences of governance analyst coverage. In particular, I focus on two different groups, i.e., (1) financial analysts, (2) investors, as well as on two firmlevel mechanisms, i.e., (3) corporate governance quality, and (4) earnings management, which are potentially affected by the presence of governance analysts.

\section{Governance Analysts and Financial Analysts}

Prior literature documents that the number of financial analysts following a firm is increasing with the quality of the firm's information environment (e.g., Bushman et al., 2004, p. 244; Lang et al., 2004, p. 589; Baik et al., 2010, p. 170). Jiraporn et al. (2012a, p. 3091-3092), for example, predict and find evidence that a "more transparent information environment facilitates the analyst's job" and in turn attracts larger analyst following. ${ }^{80}$ Thus, to the extent that governance analysts are able to enhance the firm's information environment, the number of financial analysts following a firm should increase.

In particular, transaction cost savings for financial analysts due to governance analyst coverage might explain the expected positive relationship between financial analyst following and the coverage by governance analysts. As outlined in section 4.2, transaction cost savings for financial analysts might appear in the process of gathering governance information and / or in the process of enhancing governance information (Healy and Palepu, 2002). This, however, implies two points: (1) financial analysts consider governance information when preparing analyst reports, and (2) financial analysts are able to reduce their costs of making informed decisions (i.e., coverage costs) when relying on governance information produced by governance analysts.

With respect to the former point, prior literature indeed suggests that financial analysts consider governance information when preparing analyst reports or forecasts. Bhat et al. (2006, p. 719) predict and find evidence that "analysts who are aware of the effects of the weak governance on reporting quality might rely less on the reported financial figures and instead use other sources of information" to generate analyst reports and forecasts for weakly

\footnotetext{
${ }^{80}$ However, the relation between analyst following and transparency depends substantially upon the role of financial analysts: information intermediary vs. information provider (Lobo et al., 2012, p. 498, 499). The former role is consistent with a positive relationship between analyst following and the quality of firms' information environment whereas the latter role implies the opposite. Based on different settings, prior finance and accounting literature provides evidence for both (e.g., Lobo et al., 2012, p. 499; Barth et al., 2001, p. 4; Lang et al., 2004, p. 589). As my setting is characterized by an exogenous shock in the information environment (i.e., an exogenous increase in governance information), I rather expect a positive relationship between financial analyst following and firms' transparency.
} 
governed firms. Evidence from a recent experiment based on 19 buy-side analysts from the U.S. and 17 from the UK underscores the potential effect of governance information on financial analysts. Asare et al. (2011, p. 1) show, among other things, that "analysts exhibit more certainty in their range forecast when the corporate governance rating is above average, relative to below average". However, it is still unclear whether financial analysts produce such governance information 'in-house' or whether they actually rely on other information intermediaries like, e.g., governance analysts. To the extent that governance analysts provide more accurate (in the process of enhancing governance information) and / or less expensive (in the process of gathering governance information) evaluations of governance quality, it would be rational for financial analysts to rely on governance analysts. Thus, assuming that financial analysts directly process information produced by governance analysts, the increase in governance analyst coverage potentially affects the financial analysts' costs to cover a firm, holding everything else constant (e.g., market size, firm disclosure, etc.). In particular, it is plausible to assume that the marginal costs to cover a firm are decreasing with the financial analysts' ability to efficiently allocate monitoring resources based on information which is indicative of firms' governance deficiencies. ${ }^{81}$ Decreasing marginal coverage costs might in turn increase the number of firms covered by financial analysts. This would be consistent again with the aforementioned argument that improvements in the quality of firm's (governance related) information environment attract larger financial analyst followings.

Consequently, evidence on whether or not governance analysts contribute to the quality of firms' information environment is reflected in changes of financial analyst following due to the increase in governance analyst coverage. I thus predict that governance analyst coverage is positively associated with the number of financial analysts following a firm (Prediction I).

\section{Governance Analysts and Investors}

Assuming that institutional investors base (at least partly) investment decisions on third-party governance evaluations (e.g., Rose, 2007, p. 898), an increase in governance analyst coverage should affect the ownership structure of the respective firms. For one reason, institutional

\footnotetext{
${ }^{81}$ This is consistent with Mohanram and Sunder (2006), who predict and find evidence that the introduction of Regulation FD in the U.S. results in decreasing financial analyst coverage (i.e., declining number of financial analysts following a firm) due to detrimental effects on the financial analysts' information processing costs. Specifically, Mohanram and Sunder (2006, p. 498) argue that Regulation FD leads to a higher workload of analysts per covered firm and thus promotes declining analyst coverage.
} 
investors are potentially more willing to invest in these firms due to an increase in the firm's information environment. In terms of monitoring, investors might find it less costly to monitor firms due to a more efficient allocation of monitoring resources based on information which is indicative of firms' governance deficiencies.

Consequently, holding smaller investments and owning less control rights might become less expensive due to decreasing marginal monitoring costs which in turn potentially promote investments by institutional shareholders and other investors. Therefore, more favorable investment opportunities together with an increasing coverage by financial analysts should result in increasing free float (respectively in decreasing shares of block holders). Alternatively, increasing coverage by governance analysts might simply attract the attention of institutional investors which subsequently invest in these newly covered firms. Rose (2007, p. 130), for example, notes that governance advisory services potentially play a role in the investment managers' diligence process when setting investment strategies. In any event, both rationales lead to the conclusion that governance analyst coverage potentially promotes investment opportunities and thus increases free float. Consequently, I conjecture that governance analyst coverage is positively associated with a firm's free float (Prediction II).

\section{Governance Analysts and Governance Quality}

In the course of governance analyst coverage, firms are most likely aware of the presence of such analysts. Within the data collection process ISS, for example, provides all covered firms with a unique account number and password to check and review the collected ISS governance data. This in turn allows these firms to comment on the coding of the single governance provisions. ISS "will [then] review the comments, fact check each requested data point change [and] correct/update the profile as necessary" (RiskMetrics, 2007, p. 3). In addition, ISS offers all covered firms access to a fee-based governance service (e.g., Rose, 2007, p. 902). This service provides tools to illustrate how changes in the firm's governance structure affect the respective CGQ rating. Moreover, it enables firms to perform benchmark and peer-group analyses.

Furthermore, board members are potentially responsive to third-party governance evaluations. Evidence from a recent survey based on more than 1,000 directors serving on U.S. boards conducted by Corporate Board Member and PricewaterhouseCoopers in 2008 underscores this. As outlined in section 4.2, the survey participants perceive governance 
advisors like ISS as the third most important group influencing their boards, after (1) institutional investors and (2) financial analysts, and followed by (4) plaintiff's bar, (5) the media, and (6) activist hedge funds (CBM PwC, 2008, p. 11). In a supplement study conducted in $2009,62 \%$ of the interviewed directors state that "published governance ratings will increase a board member's focus and $45 \%$ say [that] positive governance ratings help [to] attract investors" (CBM PwC, 2009, p. 7). In a similar vein, Larcker and Tayan (2011, p. 433) note that "interviews with firms suggest that both executives and board members feel pressured to change their policies to increase their governance ratings". Even though these findings are based on U.S. executives and directors, it is plausible to assume that the coverage by governance analysts might induce pressure on UK executives to improve the firm's governance quality, if necessary. Moreover, increasing investments by institutional investors - as predicted above (Prediction II) - might put pressure on the firm's management as well to improve governance quality, if necessary. Based on an international sample of firms from 23 countries between the years 2003 and 2008, Aggarwal et al. (2011), for example, show that institutional shareholders actively promote firm-level corporate governance quality. I thus conjecture that governance analyst coverage is positively associated with the quality of a firm's governance structures (Prediction III).

\section{Governance Analysts and Earnings Management}

Finally, I investigate whether improvements in outside monitoring (as potentially reflected in increasing financial analyst following and increasing institutional holdings) and firm-level corporate governance structures due to the coverage by governance analysts are reflected in increasing accounting quality (respectively decreasing earnings management).

Prior literature on corporate governance and earnings management assumes almost unanimously a constraining role of corporate governance. Following Dechow et al. (1996, p. 4), the rationale behind this is that "[i]nternal governance processes are established to maintain the credibility of firms' financial statements and safeguard against such behavior as earnings manipulation". However, the empirical findings are rather mixed (e.g., Klein, 2002; Brown et al., 2011, p. 151; Dechow et al., 2010, p. 382; Larcker et al., 2007). In contrast, prior studies on financial analysts suggest that external monitors - like financial analysts - are potentially more effective in constraining earnings management than internal governance mechanisms (Yu, 2008, p. 248; Bolton et al., 2005, p. 7). These studies argue that in most 
cases earnings management is rather driven by an agency conflict between current and future shareholders and not between managers and shareholders. ${ }^{82}$ Empirical evidence appears to be consistent with that. Prior literature documents a negative relationship between the number of financial analysts following a firm as well as the coverage by these analysts and earnings management (e.g., Yu, 2008; Degeorge et al., 2013a). Recent studies employing natural experiments based on brokerage house mergers and closures provide evidence for a causal relationship between financial analyst coverage and the firm's extent of earnings management (e.g., Irani and Oesch, 2013; Chen et al., 2013). In addition, research on the role of institutional investors suggests that these investors are potentially able to shape the firm's reporting behavior. Chung et al. (2002), for example, predict and find evidence that the presence of large institutional shareholdings constrains managers to engage in opportunistically driven earnings management. Since governance analysts presumably affect financial analysts, investors, and governance quality (Predictions I, II, and III), I finally expect that governance analyst coverage is negatively associated with the extent of a firm's earnings management (Prediction IV).

\subsection{Research Design}

\subsubsection{Identification Strategy}

Based on ISS's UK data, I measure the coverage by governance analysts on the dimension of whether or not ISS provides governance reports and commercial corporate governance ratings (CGQ ratings) to UK firms. It is plausible to assume, however, that ISS's decision to cover a firm, i.e., to provide the CGQ rating, depends on firm characteristics like institutional ownership or index membership and is thus endogenous in nature. ISS states that, in particular, index membership - MSCI EAFE for non-US companies as well as FTSE All Share Index for UK firms - is an important criterion of coverage (RiskMetrics, 2007, p. 4; RiskMetrics, 2009, p. 1; Aggarwal et al., 2009, pp. 3140-3141). As these firm characteristics are in turn most likely related to my outcome variables, i.e., analyst following, free float, governance quality, and accounting quality, ordinary OLS results are potentially biased.

\footnotetext{
${ }^{82} \mathrm{Yu}(2008$, p. 248) notes that "current shareholders could choose to incentivize management for short-term stock performance, even with the understanding that this creates incentives $[\ldots]$ to manipulate earnings".
} 
To address this problem and to provide inferences beyond mere descriptions ${ }^{83}$, I exploit the unique data structure of ISS coverage in the UK. From 2004 to 2005, ISS coverage in the UK exhibits an unusual and strong increase of almost 154\%. In comparison, the average absolute change of the remaining top five "ISS coverage countries" was around $20 \%$ between these two years whereas the average absolute change of all remaining 15 European "ISS coverage countries" was even lower with around 13\%. At the end of 2004, ISS together with FTSE developed different governance-related stock indices, with one of them explicitly focusing on the UK market (besides indices for the Japanese and the U.S. markets ${ }^{84}$ ). ${ }^{85}$ However, in order to construct the UK specific stock index with a sufficient firm base, ISS decided to enlarge the UK ISS coverage in 2005 from 209 to 530 firms (FTSE ISS CGI, 2005, pp. 4, 21; Beckley et al., 2005, p. 15). ${ }^{86}$

From an econometrician's perspective, this in turn implies that the increase of ISS coverage in the UK between the years 2004 and 2005 is exogenously caused by the joint stock indices project between ISS and FTSE, and not endogenously determined by a change in certain firm characteristics such as index membership or institutional holdings. Thus, by exploiting the exogenous shock setting, the UK sample provides a useful setting to investigate the effects of ISS governance analyst coverage. Table $4-1$ provides an overview of the ISS coverage rates across the top five countries ISS is covering (Panel A and B) as well as detailed information on the paper's identification strategy (Panel C and D).

To exploit the exogenous shock setting, I employ a twofold difference-in-difference (DiD) design based on one treatment and two natural control groups. First, I use all sample firms which are not followed by ISS analysts as my first control sample (this control group contains on average the smallest firms in the market). Additionally, I use all firm-year

\footnotetext{
${ }^{83}$ In a recent survey paper on "Causal Inference in Empirical Archival Financial Accounting Research", Gassen (2013, p. 3) states that "positivistic empirical studies that aim beyond description should allow the reader to conclude whether the observed effect is likely to be caused by the mechanism proposed by the study, or, in short: they should allow for causal inference $[\ldots] "$ ".

${ }^{84}$ On the aggregated level, the joint project considered the FTSE ISS Developed CGI, the FTSE ISS Europe CGI, and the FTSE ISS Euro CGI (FTSE ISS CGI, 2005, p. 21). In addition, the joint project explicitly focused on the UK market, the US market, and the Japanese market to release single market indices.

${ }^{85}$ In May 2005, ISS acquired the European governance advisory firm Deminor Ratings. However, the coverage of Deminor ratings was even smaller or in some instances identical to the coverage of ISS before 2005. Thus, the increase of ISS coverage after 2005 in the UK is not an outcome of a mere addition of both coverage levels.

${ }^{86}$ I am grateful to Paul Wanner (former Director of Corporate Governance Ratings at RiskMetrics / ISS) and Mark Brockway (Director of ISS Corporate Services at MSCI / ISS) for comments on the ISS coverage and the final clarification of the respective increase in UK coverage between 2004 and 2005. According to both of them, ISS's engagement in a "joint global corporate governance ratings and index project" with the explicit focus on the UK market was the primary catalyst for the unusual and strong increase in ISS coverage in the UK between 2004 and 2005.
} 
observations which were constantly covered after the exogenous shock event in 2005, but not in the period before as my treatment sample. My indicator variable measuring ISS coverage (POST $\times$ TREATED) takes the value of one if the firm belongs to the treatment group in the period after 2005, and zero otherwise. Empirically implemented in a regression model, the DiD design underlying my indicator variable (POST $\times$ TREATED) combined with a comprehensive set of fixed-effects and firm control variables assures a proper identification.

Second, corresponding to the approach described above, I use the identical treatment sample. In contrast to the previous approach, my indicator variable measuring ISS coverage (ANTE $\times$ TREATED) takes the value of one if the firm belongs to the treatment group prior to the year 2005, and zero otherwise. Consequently, my control group differs from the previous approach as well. I use all sample firms which were constantly covered by ISS analysts as my second control sample (this control group contains on average the largest firms in the market). Therefore, ANTEXTREATED indicates - in contrast to the previously defined indicator variable - the non-coverage by governance analysts. Similar to the first approach, the DiD design underlying my second indicator variable (ANTE×TREATED) efficiently addresses endogeneity concerns in a regression framework as well.

In terms of treatment assignments, this setting, however, constitutes a quasi-natural experiment rather than a pure natural experiment. Specifically, it is most likely that the treatment assignments are not random. Similar to other natural experimental settings, like, for example, brokerage house mergers or closures exploited by recent studies on sell-side equity analysts (Irani and Oesch, 2013; Chen et al., 2013; Degeorge et al., 2013b), it is plausible to assume that the treatment assignments are to some extent size related. In the current research design as outlined below, I mitigate a potential size effect by using two different control groups (a first control group with smaller firms and a second control group with larger firms), treatment and firm-fixed effects, as well as size related firm control variables within the DiD regressions. As the UK specific governance-related stock index was maintained until January 2008, regressions based on the second control group further rule out that my findings are driven by the exogenous event (i.e., joint index project) itself. As the firms of the second control group (i.e., the largest firms in the market) become also eligible to the UK joint stock index project, results based on this second control group are robust to potential effects of the joint index project on my outcome variables and thus assure the exogeneity of my quasinatural experimental setting. 
Table 4 - 1: Identification Strategy and Regression Samples

\begin{tabular}{|c|c|c|c|c|c|c|c|c|c|}
\hline \multicolumn{10}{|c|}{ Panel A. ISS Coverage } \\
\hline $\begin{array}{l}\text { ISS Firm coverage } \\
\text { per year }\end{array}$ & Rank & 2004 & 2005 & 2006 & 2007 & 2008 & $\begin{array}{l}\text { Sum } \\
\text { (p.c.) }\end{array}$ & $\begin{array}{l}\text { wscope } \\
\text { sample }\end{array}$ & $\begin{array}{c}2008 / \\
\text { wscope }\end{array}$ \\
\hline U.S. ${ }^{87}$ & 1 & 4,776 & 5,202 & 5,152 & 4,853 & 4,624 & 24,607 & 9,175 & $50.40 \%$ \\
\hline$\frac{\text { Abs. change }(|\%|)}{\text { ISS Firm coverage }}$ & & & $8.92 \%$ & $0.96 \%$ & $5.80 \%$ & $4.72 \%$ & $\frac{20.40 \%}{\text { Sum }}$ & wscope & $2007 /$ \\
\hline per year & Rank & 2003 & 2004 & 2005 & 2006 & 2007 & (p.c.) & sample & wscope \\
\hline $\begin{array}{l}\text { Japan } \\
\text { Abs. change }(|\%|)\end{array}$ & 2 & 501 & $\begin{array}{c}510 \\
1.80 \%\end{array}$ & $\begin{array}{c}589 \\
1549 \%\end{array}$ & $\begin{array}{c}600 \\
1.87 \%\end{array}$ & 600 & $\begin{array}{c}2,800 \\
1915 \%\end{array}$ & 3,668 & $16.36 \%$ \\
\hline UK & 3 & 205 & $\begin{array}{c}1.80 \% \\
209\end{array}$ & $\begin{array}{c}15.49 \% \\
\mathbf{5 3 0}\end{array}$ & $\begin{array}{l}1.8 \% \\
525\end{array}$ & $\begin{array}{c}0.00 \% \\
526\end{array}$ & $\begin{array}{l}19.15 \% \\
1,995\end{array}$ & 1,890 & $27.83 \%$ \\
\hline Abs. change $(|\%|)$ & & & $1.95 \%$ & $153.59 \%$ & $0.94 \%$ & $0.19 \%$ & $156.67 \%$ & & \\
\hline Canada & 4 & 199 & 186 & 168 & 194 & 196 & 943 & 3,364 & $5.83 \%$ \\
\hline Abs. change $(|\%|)$ & & & $6.53 \%$ & $9.68 \%$ & $15.48 \%$ & $1.03 \%$ & $32.72 \%$ & & \\
\hline Australia & 5 & 86 & 83 & 119 & 120 & 119 & 527 & 1,957 & $6.08 \%$ \\
\hline Abs. change $(|\%|)$ & & & $3.49 \%$ & $43.37 \%$ & $0.84 \%$ & $0.83 \%$ & $48.54 \%$ & & \\
\hline
\end{tabular}

Panel B. Sample Distribution \& ISS Coverage (based on sample as outlined in Table 4 - 2)

\begin{tabular}{lcccccc}
\hline & $\mathbf{2 0 0 3}$ & $\mathbf{2 0 0 4}$ & $\mathbf{2 0 0 5}$ & $\mathbf{2 0 0 6}$ & $\mathbf{2 0 0 7}$ & $\sum$ ('04-'06) \\
\hline Sample & 418 & 441 & 470 & 486 & 488 & 1,397 \\
ISS Coverage (abs) & 93 & 90 & 251 & 237 & 220 & 578 \\
ISS Coverage (\%) & 22.25 & 20.41 & 53.40 & 48.77 & 45.08 & 41.37 \\
Delta in ISS Coverage (|\%|) & & $\mathbf{3 . 2 2}$ & $\mathbf{1 7 8 . 8 9}$ & $\mathbf{5 . 5 8}$ & $\mathbf{7 . 1 7}$ & \\
\hline
\end{tabular}

Panel C. Sample Partitioning to Separate the ISS Coverage Effect: DiD-Model (1)

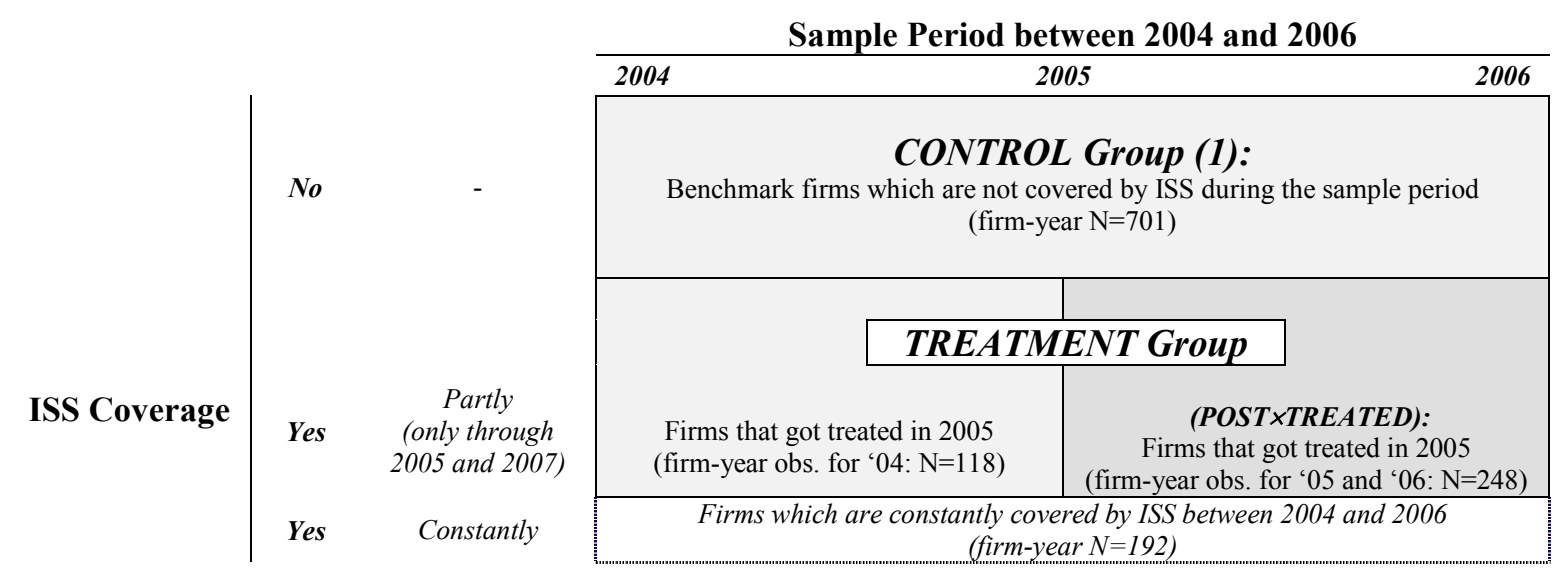

Panel D. Sample Partitioning to Separate the ISS Coverage Effect: DiD-Model (2)

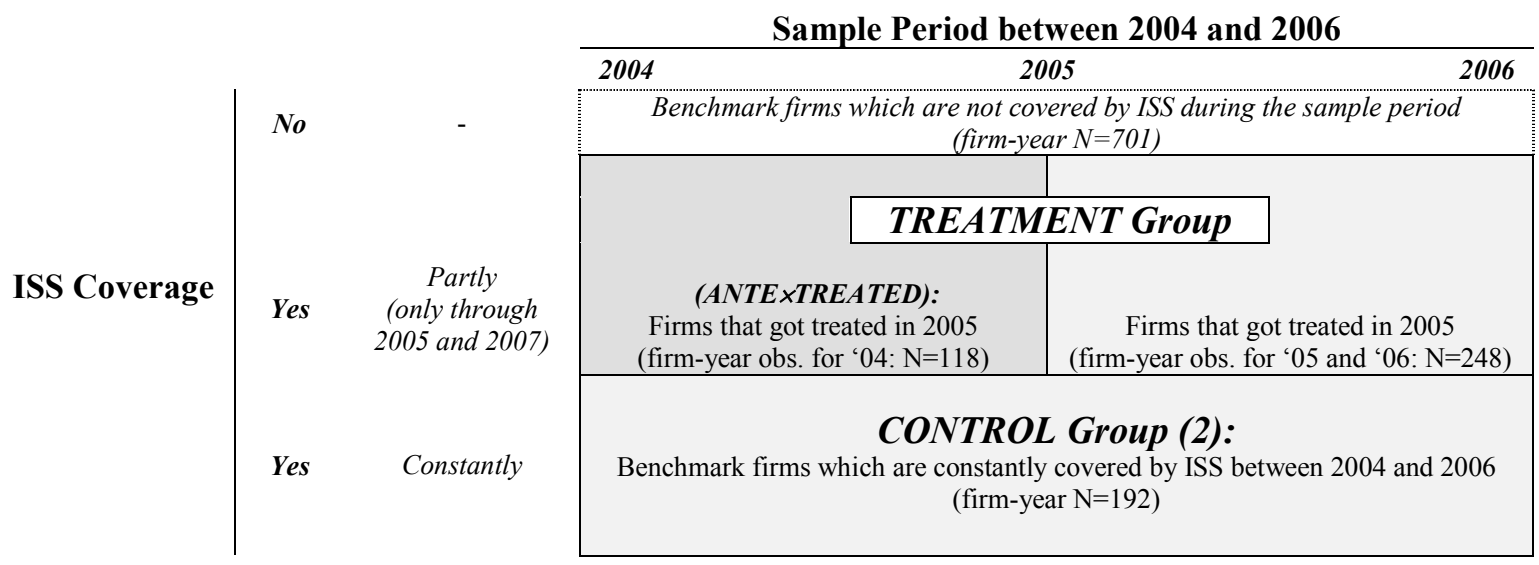

\footnotetext{
Notes: The "wscope sample" numbers are based on the "Worldscope Coverage" Guide as of February 2013
}

${ }^{87}$ U.S. CGQ coverage data is inferred from the CGQ data provided by Aggarwal et al. (2011). 
(available online from the Datastream Extranet) and represent the total number of active firms in the respective country Worldscope Universe. Identification strategy to exploit the exogenous shock in the UK ISS coverage is based on a twofold difference-in-difference (DiD) research design (with one treatment and two natural control groups).

\subsubsection{Regression Models}

To empirically implement the twofold $\mathrm{DiD}$ approach as outlined in section 4.4.1, I use the following regression design:

$$
\begin{aligned}
& \mathrm{VI}_{\mathrm{it}}=\gamma_{1}+\gamma_{2} \text { TREATED }_{\mathrm{it}}+\gamma_{3} \text { POST } \times \text { TREATED }_{\mathrm{it}}+\sum \gamma_{4} \text { FIRM_CONTROL }_{\mathrm{it}}+\sum \gamma_{5} \text { YEAR }_{\mathrm{it}} \\
& +\sum \gamma_{6} \text { INDUSTRY }_{\mathrm{it}}+\varepsilon \\
& \mathrm{VI}_{\mathrm{it}}=\gamma_{1}+\gamma_{2} \text { TREATED }_{\mathrm{it}}+\gamma_{3} \text { ANTE } \times \text { TREATED }_{\mathrm{it}}+\sum \gamma_{4} \text { FIRM_CONTROL }_{\mathrm{it}}+\sum \gamma_{5} \text { YEAR }_{\mathrm{it}} \\
& +\sum \gamma_{6} \text { INDUSTRY }_{\mathrm{it}}+\varepsilon
\end{aligned}
$$

The idea behind both regression models is to compare for a given variable of interest (VI) the changes in the treatment group around the exogenous event to the corresponding changes in the non-treated control group (e.g., Irani and Oesch, 2013, p. 402). As outlined in section 4.3, I employ different variables of interest (VI) as my left-hand side variables (i.e., proxies of financial analyst following, free float, governance quality, and earnings management). Furthermore, and as described in section 4.4.1, both regression models are based on the same treatment group (i.e., all firm-year observations which were constantly covered after 2005, but not in the period before), but differ in the underlying control group. Regression model (1) uses all sample firms which are not followed by ISS analysts as the underlying control group, whereas model (2) uses firms constantly covered by ISS as control firms. Evidence on whether or not the exogenous shock in ISS coverage results in certain differences (similarities) between the treatment firms and the constantly non-covered (constantly covered) firms, is reflected in the variable POST $\times$ TREATED (ANTE $\times$ TREATED), which indicates all firms in the treatment group after (before) 2005. This twofold $\mathrm{DiD}$ design combined with firm controls and fixed-effect structures efficiently addresses endogeneity concerns and allows for causal inferences.

In each regression model, TREATED is a dummy variable indicating the treatment group. Depending on the underlying control group, the coefficient estimates on the variables POST $\times$ TREATED and ANTE $\times$ TREATED capture the DiD effect. Consistent with the first, second, and third prediction, I expect that the coefficient estimate on POST $\times$ TREATED 
(ANTE $\times$ TREATED) obtains a positive (negative) sign and becomes significant at conventional levels in the respective regression model. In line with the fourth prediction, I expect a significantly negative (positive) coefficient estimate on POST $\times$ TREATED (ANTE $\times$ TREATED) in the earnings management regressions. FIRM_CONTROL is a regression model specific vector of firm characteristics which potentially affect the respective left-hand side variable. To control for year- and industry-fixed effects, I include dummies for different years and different first-digit SIC industry sectors. Alternatively to industry-fixed effects and the inclusion of TREATED, I additionally estimate the regressions with firm-fixed effects (e.g., Irani and Oesch, 2013, p. 402). In all regression models, the standard errors are heteroskedasticity robust (White, 1980) and one-way clustered at the firm level (Gow et al., 2010; Petersen 2009).

\subsubsection{Variables Measurement}

Analogous to the stated predictions in section 4.3, I use the following variables of interest (VI) as my left-hand side variables: number of analysts following a firm (AF), free float of a firm $(\mathrm{FF})$, corporate governance quality score (GOV) provided by ASSET4 ${ }^{88}$, and absolute discretionary accruals (ADAC) measuring earnings management (respectively accounting quality) as outlined in section 4.4.4.

In line with prior literature (e.g., Bhushan, 1989, p. 268; O’Brien and Bhushan, 1990, pp. 59-62; Lang et al., 2004, pp. 605-606; Jiraporn et al., 2012a, p. 3095), I consider a variety of firm control variables in the financial analyst following (AF) regression: blue chip index membership (FTSE100), availability of alternative governance information (asset4 coverage), capital intensity (property, plant, and equipment to total assets), volatility of business (standard deviation of cash from operations), stock price volatility (standard deviation of monthly stock returns), brokerage commission (inverse stock price), accounting performance (ROA), growth (book-to-market ratio), institutional investors (pension funds holdings), ownership concentration (closely held shares), size (log of total assets), and leverage (total debt to total assets).

\footnotetext{
${ }^{88}$ I use the ASSET4 governance score to evaluate the governance quality of the treatment group before and after the coverage by ISS analysts (for more information on ASSET4, see, e.g., Mackenzie et al., 2013, p. 502; Lys et al., 2012, p. 9). However, due to data restrictions in the ASSET4 database I run the governance regression only on a subsample (with respect to treatment and control group) and only on the second DiD model (with ANTE $\times$ TREATED as the main interest variable).
} 
In the free float $(\mathrm{FF})$ regression model, I follow the first $(\mathrm{AF})$ regression specification, but replace closely held shares, pension funds holding, book-to-market ratio, capital intensity, standard deviation of cash from operations, and brokerage commission with analyst following and dividends per share (e.g., Van der Elst, 2004, pp. 427, 438; Richter and Weiss, 2013, pp. 6-7).

To specify the governance (GOV) regression model, I follow Beiner et al. (2006, pp. 253-254) and control for size (log of total assets), growth (one-year change in net sales), accounting performance (return-on-assets), blue chip index membership (FTSE100), and firm valuation (Tobin's Q). In addition, I consider analyst following, institutional investments (pension funds holdings), ownership concentration (closely held shares), and leverage (total debt to total assets).

In line with prior earnings management studies (e.g., Klein, 2002, p. 388; Koh et al., 2007, pp. 318-319; Bowen et al., 2009, pp. 367-371), I include the following control variables in the discretionary accruals (ADAC) regression: size (log of total assets), blue chip index membership (FTSE100), analyst following, availability of alternative governance information (asset4 coverage), institutional investments (pension funds holdings), ownership concentration (closely held shares), loss reporting, cash from operations, and leverage (total debt to total assets). ${ }^{89}$

\subsubsection{Discretionary Accruals}

Discretionary accruals are estimated on an extended cross-sectional modified Jones model based on the cash flow approach and total accruals (e.g., Garcia Lara et al., 2012, p. 12; Botsari and Meeks, 2008; Hribar and Collins, 2002). To control for growth characteristics (Collins et al., 2012) and firm performance (Kothari et al., 2005), I include growth and oneyear lagged ROA as additional explanatory variables in the model. Overall, I estimate discretionary accruals for each two-digit SIC industry group and year by the following regression model based on all available non-financial UK Worldscope firms (with at least 15 observations per industry-year group):

\footnotetext{
${ }^{89}$ Consistent with Larcker et al. (2007, p. 987), I do not control for growth opportunities and performance within the ADAC regression model since my ADACs are orthogonal to growth and performance due to the applied estimation model. However, when considering additionally ROA and growth in the basic regression model the main inferences remain unaffected. For detailed information and definitions of all variables used in this study, see Appendix 4 - 1.
} 


$$
\begin{aligned}
\mathrm{TAC}_{i t} / \mathrm{TA}_{\mathrm{it}-1}= & \beta_{1}+\beta_{2}\left(1 / \mathrm{TA}_{\mathrm{it}-1}\right)+\beta_{3}\left[\left(\Delta \mathrm{REV}_{\mathrm{it}} / \mathrm{TA}_{\mathrm{it}-1}\right)-\left(\Delta \mathrm{REC} \mathrm{it}_{\mathrm{it}} / \mathrm{TA}_{\mathrm{it}-1}\right)\right] \\
& +\beta_{4}\left(\mathrm{PPE}_{\mathrm{it}} / \mathrm{TA}_{\mathrm{it}-1}\right)+\beta_{4}\left(\mathrm{GROWTH}_{\mathrm{it}}\right)+\beta_{5}\left(\mathrm{ROA}_{\mathrm{it}-1}\right)+\varepsilon_{\mathrm{i}}
\end{aligned}
$$

The dependent variable TAC stands for total accruals and is obtained directly from the cash flow statement (total accruals as net income minus cash from operations). $\triangle$ REV stands for changes in revenues, $\triangle$ REC represents changes in receivables, PPE is property, plant and equipment, GROWTH measures current one-year growth in sales, ROA stands for return-onassets. The residuals of regression model (3) are the discretionary accruals (DAC).

\subsection{Results}

\subsubsection{Sample Selection}

The sample covers - with the UK market - the largest European and worldwide - after the U.S. and Japan - the third largest country ${ }^{90}$ in which ISS offers commercial corporate governance ratings and proxy voting advisory. Therefore, the initial sample is based on all listed firms available in the UK Worldscope database. The sample period covers the years between 2004 and 2006. ${ }^{91}$ After applying certain selection criteria (e.g., dropping firms with missing accounting data, or firms from financial industry, or firms with no financial analyst following), the sample consists of 1,397 firm-year observations with an ISS coverage quote of $41.37 \%$. Table 4 - 2 summarizes the sample selection procedure and provides further details on the sample composition.

Table 4 - 2: Sample Selection

Panel A. Selection Criteria

\begin{tabular}{lcc}
\hline Selection Criteria & Observations \\
Start (Worldscope UK Universe from 2004-2006) & 7,413 \\
Firms in financial industry (SIC 60-69) & $-2,235$ & 5,178 \\
Datastream / Worldscope data unavailable (to estimate DAC) & $-1,058$ & 4,120 \\
Two-digit SIC-year-country min. requirement: >15 obs. (to estimate DAC) & -951 & 3,169 \\
Datastream / Worldscope / IBES data unavailable (to specify control VAR) & $-1,138$ & 2,031 \\
Firms without at least one financial analyst following & -634 & 1,397 \\
\hline Final Sample (firm-year observations between 2004-2006): & $\mathbf{1 , 3 9 7}$ \\
\hline
\end{tabular}

\footnotetext{
${ }^{90}$ In terms of number of firms covered by ISS (see Table 4 - 1).

${ }^{91}$ Using alternative sample periods, e.g., without the exogenous shock year (sample is based on 2004 and 2006 only), or without the year after the exogenous shock (sample is based on 2004 and 2005 only) does not alter my main inferences.
} 


\subsubsection{Descriptive Statistics}

Table 4 - 3 presents descriptive statistics of all variables used in this study based on different subsamples. Panel A (Panel B) of Table 4 - 3 covers separately the samples of the treatment group and both control groups before (after) the exogenous shock in ISS coverage in 2005 . Consistent with the paper's identification strategy, firms in both groups - the treatment and the first control group - are not covered by ISS analysts before 2005. In addition, firms belonging to the second control group are constantly covered by ISS analysts over the whole sample period from 2004 to 2006. Reflecting the exogenous shock in ISS coverage, firms in the treatment group are not covered before 2005 but constantly afterwards. Overall, firms across all three subsamples (treatment, control 1, and control 2) differ on various dimensions. In contrast to the first (second) control group, firms in the treatment sample, for example, have, on average, higher (lower) analyst following, higher free float, higher absolute discretionary accruals, higher (lower) pension funds holdings, lower (higher) ownership concentration, and higher (lower) total assets in the year prior to the exogenous shock (Panel A of Table $4-3$ ).

Table 4 - 3: Descriptive Analysis

Panel A: Sample Period: 2004 (prior to the exogenous shock in ISS coverage)

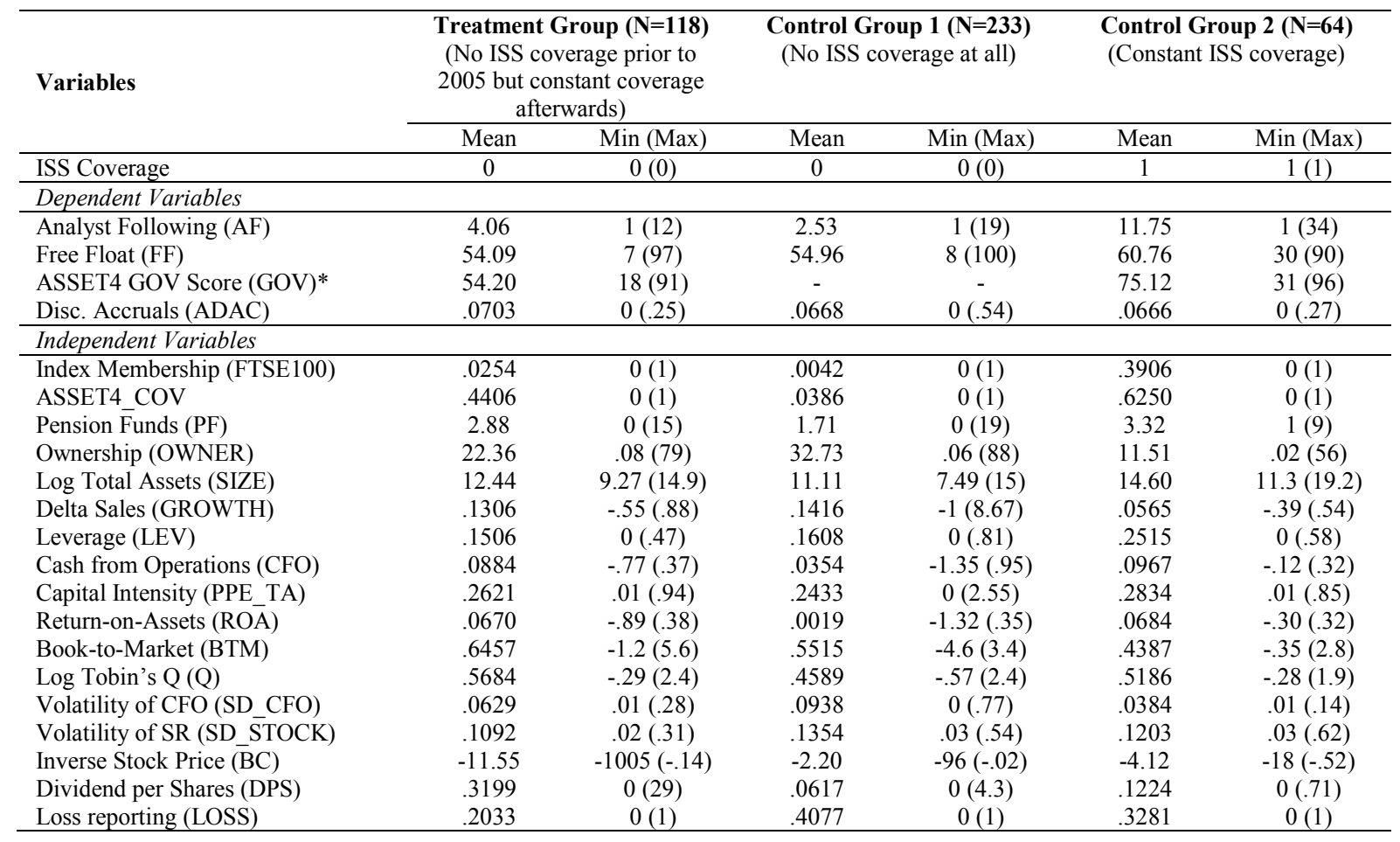


Table 4 - 3: Descriptive Analysis (continued)

Panel B: Sample Period: 2005-2006 (after the exogenous shock in ISS coverage)

\begin{tabular}{|c|c|c|c|c|c|c|}
\hline \multirow[t]{2}{*}{ Variables } & \multicolumn{2}{|c|}{$\begin{array}{c}\text { Treatment Group }(\mathbf{N}=\mathbf{2 4 8}) \\
\text { (No ISS coverage prior to } \\
2005 \text { but constant coverage } \\
\text { afterwards) }\end{array}$} & \multicolumn{2}{|c|}{$\begin{array}{l}\text { Control Group } 1(\mathbf{N}=\mathbf{4 6 8}) \\
\text { (No ISS coverage at all) }\end{array}$} & \multicolumn{2}{|c|}{$\begin{array}{l}\text { Control Group } 2(\mathbf{N}=\mathbf{1 2 8}) \\
\text { (Constant ISS coverage) }\end{array}$} \\
\hline & Mean & Min (Max) & Mean & $\operatorname{Min}(\operatorname{Max})$ & Mean & $\operatorname{Min}(\operatorname{Max})$ \\
\hline ISS Coverage & 1 & $1(1)$ & 0 & $0(0)$ & 1 & $1(1)$ \\
\hline \multicolumn{7}{|l|}{ Dependent Variables } \\
\hline Analyst Following (AF) & 5.47 & $1(24)$ & 1.82 & $1(16)$ & 11.74 & $1(42)$ \\
\hline Free Float $(\mathrm{FF})$ & 58.78 & $12(100)$ & 55.48 & $6(100)$ & 61.66 & $21(100)$ \\
\hline ASSET4 GOV Score (GOV)* & 58.86 & $10(92)$ & - & - & 70.31 & $26(96)$ \\
\hline Disc. Accruals (ADAC) & .0556 & $0(.51)$ & .0952 & $0(.55)$ & .0514 & $0(.19)$ \\
\hline \multicolumn{7}{|l|}{ Independent Variables } \\
\hline Index Membership (FTSE100) & .0403 & $0(1)$ & .0064 & $0(1)$ & .3828 & $0(1)$ \\
\hline ASSET4_COV & .4556 & $0(1)$ & .0235 & $0(1)$ & .7812 & $0(1)$ \\
\hline Pension Funds (PF) & 1.55 & $0(71)$ & .5662 & $0(20)$ & 1.32 & $0(6)$ \\
\hline Ownership (OWNER) & 21.20 & $1(89)$ & 35.52 & $.02(98)$ & 14.42 & $.01(56)$ \\
\hline Log Total Assets (SIZE) & 12.57 & $9.2(19)$ & 10.44 & $6.7(15.3)$ & 14.58 & $10.9(19.1)$ \\
\hline Delta Sales (GROWTH) & .1703 & $-.74(5.8)$ & .2413 & $-.78(12.1)$ & .0460 & $-.91(1.51)$ \\
\hline Leverage (LEV) & .1759 & $0(1.33)$ & .1429 & $0(1.60)$ & .2516 & $0(1.17)$ \\
\hline Cash from Operations (CFO) & .0901 & $-.66(.37)$ & .0146 & $-1.8(.34)$ & .0849 & $-.35(.29)$ \\
\hline Capital Intensity (PPE_TA) & .2401 & $0(.94)$ & .1803 & $0(.96)$ & .2586 & $0(.92)$ \\
\hline Return-on-Assets (ROA) & .0792 & $-1.09(.48)$ & -.0280 & $-2.5(.71)$ & .0834 & $-.42(.38)$ \\
\hline Book-to-Market (BTM) & .4932 & $-4.5(4.9)$ & .6181 & $-1.2(11.7)$ & .3775 & $-.42(2.1)$ \\
\hline Log Tobin’s Q (Q) & .6572 & $-.32(2.41)$ & .5623 & $-.59(2.41)$ & .5754 & $-.36(1.55)$ \\
\hline Volatility of CFO (SD_CFO) & .0629 & $.01(.29)$ & .1514 & $0(9.6)$ & .0390 & $0(.14)$ \\
\hline Volatility of SR (SD_STOCK) & .0857 & $.03(.32)$ & .1239 & $.02(1.0)$ & .0738 & $.02(.19)$ \\
\hline Inverse Stock Price $(\overline{B C})$ & -16.86 & $-1777(-.06)$ & -2.73 & $-445(-.01)$ & -4.93 & $-28.2(-.28)$ \\
\hline Dividend per Shares (DPS) & .3621 & $0(36)$ & .0251 & $0(.46)$ & .1405 & $0(.9)$ \\
\hline Loss reporting (LOSS) & .1814 & $0(1)$ & .3846 & $0(1)$ & .1953 & $0(1)$ \\
\hline
\end{tabular}

Notes: *The sample size w.r.t. ASSET4 GOV score is restricted (Panel A: Treatment sample $\mathrm{N}=40$ \&

Control Group 2 sample $\mathrm{N}=52$; Panel $\mathrm{B}$ : Treatment sample $\mathrm{N}=113$ \& Control Group 2 sample $\mathrm{N}=100$ ).

This table displays the descriptive statistics of all variables used on this study. For details on the sample selection process, see Table 4 - 2. For variable definition, see Appendix 4 - 1.

Comparisons of the differences in the differences across the treatment and both control groups before and after the exogenous shock event allow for first descriptive evidence on the role of governance analysts. In particular, for firms in the treatment group, mean values for analyst following $(+1.41$ analyst), for free float $(+4.69$ percentage points), and for governance quality (+4.66 percentage points), are increasing after the exogenous shock, whereas the average absolute discretionary accruals (-1.47 percentage points) is decreasing. ${ }^{92}$ In line with the paper's first three predictions, firms in both control groups do not experience, on average, a similar increase in analyst following, free float and governance quality. ${ }^{93}$ Changes in absolute discretionary accruals across both control groups, however, reveal a mixed picture. Firms in the first control group exhibit an increase in absolute discretionary accruals $(+2.84$ percentage points), whereas firms in the second control group experience a similar decrease in

\footnotetext{
${ }^{92}$ Control Group 1: analyst following ( -0.71 analyst), for free float $(+0.52$ percentage points), and discretionary accruals (+2.84 percentage points). Control Group 2: analyst following ( -0.01 analyst), for free float $(+0.90$ percentage points), for governance quality ( -4.81 percentage points), and absolute discretionary accruals ( -1.52 percentage points).

${ }_{93}$ Owing to data restrictions in the ASSET4 database, differences in differences on the governance dimension are only observable between the treatment group and the second control group (i.e., constantly covered firms).
} 
absolute discretionary accruals (-1.52 percentage points) as the treated firms after the exogenous shock. However, since these results do not consider the DiD design in a framework with fixed-effects and firm controls, the above stated inferences are only tentative.

Table 4 - 4: Correlation Analysis

\begin{tabular}{|c|c|c|c|c|c|c|c|c|c|c|c|c|}
\hline \multirow{2}{*}{$\begin{array}{l}\text { Sample } \\
(\mathrm{N}=1,397)\end{array}$} & \multicolumn{12}{|c|}{ Non-parametric Spearman Correlations } \\
\hline & & 1 & 2 & 3 & 4 & 5 & 6 & 7 & 8 & 9 & 10 & 11 \\
\hline ISS_COV & 1 & 1 & & & & & & & & & & \\
\hline $\mathbf{A F}$ & 2 & $\begin{array}{l}0.619 \\
(0.00)\end{array}$ & 1 & & & & & & & & & \\
\hline FF & 3 & $\begin{array}{l}0.083 \\
(0.00)\end{array}$ & $\begin{array}{l}0.035 \\
(0.19)\end{array}$ & 1 & & & & & & & & \\
\hline GOV* & 4 & $\begin{array}{l}0.239 \\
(0.00)\end{array}$ & $\begin{array}{l}0.358 \\
(0.00)\end{array}$ & $\begin{array}{l}0.031 \\
(0.54)\end{array}$ & 1 & & & & & & & \\
\hline ADAC & 5 & $\begin{array}{l}-0.151 \\
(0.00)\end{array}$ & $\begin{array}{r}-0.197 \\
(0.00)\end{array}$ & $\begin{array}{l}-0.036 \\
(0.17)\end{array}$ & $\begin{array}{l}-0.035 \\
(0.50)\end{array}$ & 1 & & & & & & \\
\hline FSTE100 & 6 & $\begin{array}{l}0.314 \\
(0.00)\end{array}$ & $\begin{array}{l}0.421 \\
(0.00)\end{array}$ & $\begin{array}{l}0.069 \\
(0.01)\end{array}$ & $\begin{array}{l}0.313 \\
(0.00)\end{array}$ & $\begin{array}{l}-0.125 \\
(0.00)\end{array}$ & 1 & & & & & \\
\hline ASSET4_COV & 7 & $\begin{array}{l}0.503 \\
(0.00)\end{array}$ & $\begin{array}{l}0.627 \\
(0.00)\end{array}$ & $\begin{array}{l}0.112 \\
(0.00)\end{array}$ & $\begin{array}{l}- \\
-\end{array}$ & $\begin{array}{l}-0.160 \\
(0.00)\end{array}$ & $\begin{array}{l}0.424 \\
(0.00)\end{array}$ & 1 & & & & \\
\hline PF & 8 & $\begin{array}{l}0.132 \\
(0.00)\end{array}$ & $\begin{array}{l}0.348 \\
(0.00)\end{array}$ & $\begin{array}{l}-0.289 \\
(0.00)\end{array}$ & $\begin{array}{l}0.116 \\
(0.02)\end{array}$ & $\begin{array}{l}-0.057 \\
(0.03)\end{array}$ & $\begin{array}{l}0.122 \\
(0.00)\end{array}$ & $\begin{array}{l}0.190 \\
(0.00)\end{array}$ & 1 & & & \\
\hline OWNER & 9 & $\begin{array}{l}-0.367 \\
(0.00)\end{array}$ & $\begin{array}{l}-0.442 \\
(0.00)\end{array}$ & $\begin{array}{l}-0.363 \\
(0.00)\end{array}$ & $\begin{array}{l}-0.195 \\
(0.00)\end{array}$ & $\begin{array}{l}0.104 \\
(0.00)\end{array}$ & $\begin{array}{l}-0.239 \\
(0.00)\end{array}$ & $\begin{array}{l}-0.409 \\
(0.00)\end{array}$ & $\begin{array}{l}-0.274 \\
(0.00)\end{array}$ & 1 & & \\
\hline SIZE & 10 & $\begin{array}{l}0.641 \\
(0.00)\end{array}$ & $\begin{array}{l}0.813 \\
(0.00)\end{array}$ & $\begin{array}{l}0.107 \\
(0.00)\end{array}$ & $\begin{array}{l}0.442 \\
(0.00)\end{array}$ & $\begin{array}{l}-0.212 \\
(0.00)\end{array}$ & $\begin{array}{l}0.443 \\
(0.00)\end{array}$ & $\begin{array}{l}0.658 \\
(0.00)\end{array}$ & $\begin{array}{l}0.365 \\
(0.00)\end{array}$ & $\begin{array}{l}-0.462 \\
(0.00)\end{array}$ & 1 & \\
\hline LEV & 11 & $\begin{array}{l}0.226 \\
(0.00)\end{array}$ & $\begin{array}{l}0.304 \\
(0.00)\end{array}$ & $\begin{array}{l}0.031 \\
(0.25)\end{array}$ & $\begin{array}{l}0.066 \\
(0.20)\end{array}$ & $\begin{array}{l}-0.143 \\
(0.00)\end{array}$ & $\begin{array}{l}0.193 \\
(0.00)\end{array}$ & $\begin{array}{l}0.238 \\
(0.00)\end{array}$ & $\begin{array}{l}0.130 \\
(0.00)\end{array}$ & $\begin{array}{l}-0.170 \\
(0.00)\end{array}$ & $\begin{array}{l}0.430 \\
(0.00)\end{array}$ & 1 \\
\hline ROA & 12 & $\begin{array}{l}0.226 \\
(0.00)\end{array}$ & $\begin{array}{l}0.295 \\
(0.00)\end{array}$ & $\begin{array}{l}-0.019 \\
(0.47)\end{array}$ & $\begin{array}{l}-0.011 \\
(0.83)\end{array}$ & $\begin{array}{l}-0.171 \\
(0.00)\end{array}$ & $\begin{array}{l}0.164 \\
(0.00)\end{array}$ & $\begin{array}{l}0.288 \\
(0.00)\end{array}$ & $\begin{array}{l}0.060 \\
(0.02)\end{array}$ & $\begin{array}{l}-0.076 \\
(0.00)\end{array}$ & $\begin{array}{l}0.246 \\
(0.00)\end{array}$ & $\begin{array}{c}-0.018 \\
(0.51)\end{array}$ \\
\hline
\end{tabular}

Notes: *The sample size w.r.t. ASSET4 GOV score is restricted $(\mathrm{N}=387)$. This table reports non-parametric Spearman correlation coefficients. For detailed information and definitions of the variables, see Appendix 4 - 1 . Reported values: coefficients ( $\mathrm{p}$-values).

Complementing the descriptive statistics, Table 4 - 4 provides non-parametric Spearman correlation coefficients based on the initial sample of 1,397 firm-year observations. In the absence of any subsample and $\mathrm{DiD}$ analyses, I observe that the coverage by ISS governance analysts (ISS_COV) is significantly and positively (negatively) correlated with analyst following, and free float, governance quality (absolute discretionary accruals). In addition, analyst following, free float, and governance quality are likewise negatively correlated with absolute discretionary accruals, yet, not in all cases on a statistically meaningful level. ${ }^{94}$

\subsubsection{Regression Results}

Table 4 - 5 presents the main regression results along the paper's predictions. Consistent with

\footnotetext{
${ }^{94}$ In response to some high correlation coefficients (e.g., between SIZE and AF), I perform multicollinearity tests for all explanatory variables used in the regression models. In particular, the Variance Inflation Factors (VIF) do not exceed 3.27 in the DiD regressions implying that my inferences are not affected by multicollinearity concerns (e.g., Gujarati, 2003, p. 362).
} 
the first prediction that the exogenous shock in ISS coverage causes an increase in analyst following, the coefficient estimates on POST $\times$ TREATED (ANTE $\times$ TREATED) obtain a positive (negative) sign and become significant at conventional levels in both specifications, with and without firm fixed effects (Panel A, Table 4 - 5). Prediction 2, in contrast, is supported only by the first DiD regression model ('Treatment \& Control 1'). Although both coefficient estimates reflecting the DiD effect, POST $\times$ TREATED and ANTE $\times$ TREATED, obtain the expected sign in the free float regression, only the former becomes significant at conventional levels (Panel B, Table 4 - 5). Since the coverage of ASSET4 governance data is limited, Prediction 3 is only tested on the second DiD regression model ('Treatment \& Control 2') with a restricted sample size. In line with the third prediction that the exogenous shock in ISS coverage causes improvements in firm-level governance quality, the coefficient estimates on ANTE×TREATED obtain a negative sign and become significant at conventional levels in both specifications, with and without firm-fixed effects (Panel C, Table 4 - 5). Finally, Panel D presents the corresponding results for the earnings management DiD regressions. Similar to the free float findings, Prediction 4 is only supported by the first DiD regression model ('Treatment \& Control 1'). Again, both coefficient estimates reflecting the DiD effect obtain the expected sign in the earnings management regression. However, only the coefficient estimates on POST $\times$ TREATED become significant at conventional levels (Panel B, Table 4 - 5).

In sum, the results so far show that the exogenous increase in ISS analyst coverage results (1) in increasing analyst following (on average by one analyst), (2) weakly in increasing free float (on average by 4.2 percentage points), (3) in improvements of firm-level corporate governance quality (on average by 7.4 percentage points), and (4) weakly in decreasing accruals manipulations (on average by 1.8 percentage points). Consistent with the paper's predictions, these findings suggest that financial analysts, investors, and managers respond to changes in governance analyst coverage. Specifically, they imply - in line with the paper's first and second prediction - that financial analysts and investors potentially consider governance information provided by governance analysts when preparing analyst reports or setting investment strategies, respectively. Moreover, the findings further indicate that both, financial analysts and investors, are potentially able to reduce their costs of making informed decisions when relying on information provided by governance analysts. In addition and consistent with the paper's third prediction, the findings also suggest that managers and directors feel potentially pressured by the presence of governance analyst to improve governance quality, if 
necessary. Overall, the paper's findings are consistent with the notion that governance analysts represent economically important information intermediaries who enhance the firm's information environment and promote external monitoring to managers. ${ }^{95}$

Table 4 - 5: DiD Regression Analyses

Panel A. Prediction 1: Governance Analysts and Financial Analysts

\begin{tabular}{|c|c|c|c|c|c|c|c|}
\hline & \multirow{3}{*}{$\begin{array}{l}\text { Pred. } \\
\text { Sign }\end{array}$} & \multicolumn{6}{|c|}{ Dependent variable: Analyst Following } \\
\hline & & \multicolumn{2}{|c|}{$\begin{array}{c}\text { Sample consists of } \\
\text { Treatment \& Control } 1\end{array}$} & \multicolumn{2}{|c|}{$\begin{array}{c}\text { Sample consists of } \\
\text { Treatment \& Control } 2\end{array}$} & \multicolumn{2}{|c|}{$\begin{array}{c}\text { Sample consists of } \\
\text { Control } 1 \text { \& Control } 2\end{array}$} \\
\hline & & Model 1 & Model 2 & Model 3 & Model 4 & Model 5 & Model 6 \\
\hline POST_TREATED & + & $\begin{array}{l}1.1508 * * * \\
(5.10)\end{array}$ & $\begin{array}{l}.8814 * * * \\
(3.23)\end{array}$ & & & & \\
\hline ANTE_TREATED & - & & & $\begin{array}{c}-.9619 * * \\
(-2.04)\end{array}$ & $\begin{array}{l}-.9789 * \\
(-1.73)\end{array}$ & & \\
\hline SPILLOVER & & & & & & $\begin{array}{l}-.6826 \\
(-1.55)\end{array}$ & $\begin{array}{l}-.4693 \\
(-0.82)\end{array}$ \\
\hline FIRM CONTROL VARs & & Yes & Yes & Yes & Yes & Yes & Yes \\
\hline YEAR fixed effect & & Yes & Yes & Yes & Yes & Yes & Yes \\
\hline IND fixed effect & & Yes & No & Yes & No & Yes & No \\
\hline FIRM fixed effect & & No & Yes & No & Yes & No & Yes \\
\hline Sample Size & & 1067 & 1067 & 558 & 558 & 1031 & 1031 \\
\hline Adj. $R^{2}$ & & .5496 & .8400 & 6987 & .9013 & .7089 & .9085 \\
\hline
\end{tabular}

Panel B. Prediction 2: Governance Analysts and Investors

\begin{tabular}{|c|c|c|c|c|c|c|c|}
\hline & \multirow{3}{*}{$\begin{array}{r}\text { Pred. } \\
\text { Sign }\end{array}$} & \multicolumn{6}{|c|}{ Dependent variable: Free Float } \\
\hline & & \multicolumn{2}{|c|}{ Treatment \& Control 1} & \multicolumn{2}{|c|}{ Treatment \& Control 2} & \multicolumn{2}{|c|}{ Control $1 \&$ Control 2} \\
\hline & & Model 1 & Model 2 & Model 3 & Model 4 & Model 5 & Model 6 \\
\hline POST_TREATED & + & $\begin{array}{c}4.7748 * * \\
(2.22)\end{array}$ & $\begin{array}{c}5.2970 * \\
(1.72)\end{array}$ & & & & \\
\hline ANTE_TREATED & - & & & $\begin{array}{c}-3.7783 \\
(-1.48)\end{array}$ & $\begin{array}{c}-3.2452 \\
(-1.01)\end{array}$ & & \\
\hline SPILLOVER & & & & & & $\begin{array}{l}.6500 \\
(0.29)\end{array}$ & $\begin{array}{l}-.1377 \\
(-0.04)\end{array}$ \\
\hline FIRM CONTROL VARs & & Yes & Yes & Yes & Yes & Yes & Yes \\
\hline YEAR fixed effect & & Yes & Yes & Yes & Yes & Yes & Yes \\
\hline IND fixed effect & & Yes & No & Yes & No & Yes & No \\
\hline FIRM fixed effect & & No & Yes & No & Yes & No & Yes \\
\hline Sample Size & & 1067 & 1067 & 558 & 558 & 1031 & 1031 \\
\hline Adj. $\mathrm{R}^{2}$ & & .2472 & .5790 & .4962 & .6676 & .2707 & .5878 \\
\hline
\end{tabular}

Panel C. Prediction 3: Governance Analysts and Corporate Governance

\begin{tabular}{|c|c|c|c|c|c|c|c|}
\hline & \multirow{3}{*}{$\begin{array}{l}\text { Pred. } \\
\text { Sign }\end{array}$} & \multicolumn{6}{|c|}{ Dependent variable: Corporate Governance Quality (ASSET4) } \\
\hline & & \multicolumn{2}{|c|}{ Treatment \& Control 1} & \multicolumn{2}{|c|}{ Treatment \& Control 2} & \multicolumn{2}{|c|}{ Control $1 \&$ Control 2} \\
\hline & & Model 1 & Model 2 & Model 3 & Model 4 & Model 5 & Model 6 \\
\hline POST_TREATED & + & & & & & & \\
\hline ANTE_TREATED & - & & & $\begin{array}{c}-9.0381 * * * \\
(-3.17)\end{array}$ & $\begin{array}{c}-5.9503 * \\
(-1.82) \\
\end{array}$ & & \\
\hline \multicolumn{8}{|l|}{ SPILLOVER } \\
\hline FIRM CONTROL VARs & & & & Yes & Yes & & \\
\hline YEAR fixed effect & & & & Yes & Yes & & \\
\hline IND fixed effect & & & & Yes & No & & \\
\hline FIRM fixed effect & & & & No & Yes & & \\
\hline Sample Size & & & & 305 & 305 & & \\
\hline Adj. $\mathrm{R}^{2}$ & & & & .2791 & .6936 & & \\
\hline
\end{tabular}

95 Alternatively, the paper's findings might be also consistent with an "attention" story (instead of an "information" story). Without any information enhancing activities by governance analysts, the coverage by these analysts might simply attract the attention of institutional investors which subsequently invest in these newly covered firms (e.g., because governance ratings might serve as a tool to vindicate the funds manager's investment strategies). This in turn might attract financial analysts and might promote monitoring to the firm's management. 


\section{Table 4 - 5: DiD Regression Analyses (continued)}

Panel D. Prediction 4: Governance Analysts and Earnings Management

\begin{tabular}{|c|c|c|c|c|c|c|c|}
\hline & \multirow{3}{*}{$\begin{array}{l}\text { Pred. } \\
\text { Sign }\end{array}$} & \multicolumn{6}{|c|}{ Dependent variable: Absolute Discretionary Accruals } \\
\hline & & \multicolumn{2}{|c|}{ Treatment \& Control 1} & \multicolumn{2}{|c|}{ Treatment \& Control 2} & \multicolumn{2}{|c|}{ Control 1 \& Control 2} \\
\hline & & Model 1 & Model 2 & Model 3 & Model 4 & Model 5 & Model 6 \\
\hline POST_TREATED & - & $\begin{array}{c}-.0361 * * * \\
(-3.83)\end{array}$ & $\begin{array}{c}-.0344 * * * \\
(-2.61)\end{array}$ & & & & \\
\hline ANTE_TREATED & + & & & $\begin{array}{l}.0009 \\
(0.09)\end{array}$ & $\begin{array}{l}.0020 \\
(0.15)\end{array}$ & & \\
\hline SPILLOVER & & & & & & $\begin{array}{c}-.0271 * * * \\
(-2.88)\end{array}$ & $\begin{array}{c}-.0291 * * \\
(-2.12)\end{array}$ \\
\hline FIRM CONTROL VARs & & Yes & Yes & Yes & Yes & Yes & Yes \\
\hline YEAR fixed effect & & Yes & Yes & Yes & Yes & Yes & Yes \\
\hline IND fixed effect & & Yes & No & Yes & No & Yes & No \\
\hline FIRM fixed effect & & No & Yes & No & Yes & No & Yes \\
\hline Sample Size & & 1067 & 1067 & 558 & 558 & 1031 & 1031 \\
\hline Adj. $\mathrm{R}^{2}$ & & .1183 & .4082 & .0719 & .1804 & .1432 & .4530 \\
\hline
\end{tabular}

The underlying basic regression model is:

$$
\begin{gathered}
\text { VI }_{\text {it }}=\alpha+\gamma_{1} \text { TREATED }_{\text {it }}+\gamma_{2} \text { POST } \times \text { TREATED }_{\text {it }}\left[\gamma_{2} \text { ANTE } \times \text { TREATED }_{\text {it }}\right]+\sum \gamma_{2} \text { FIRM_CONTROL }_{\text {it }} \\
+\sum \gamma_{3} \text { YEAR }_{i t}+\sum \gamma_{4} \text { INDUSTRY }_{\text {it }}+\varepsilon
\end{gathered}
$$

TREATED is a dummy variable indicating the treatment group. Depending on the underlying control group, the coefficient estimates on the variables POST $\times$ TREATED and ANTEXTREATED capture the difference-indifference effect (for definitions of treatment and control group, see Table 4 - 1). Firm control for analyst following (AF) regression (Panel A): blue chip index membership (FTSE100), alternative governance information (asset4 coverage), capital intensity (PPE to total assets), volatility of business (StD of cash from operations), stock price volatility (StD of monthly stock returns), brokerage commission (inverse stock price), accounting performance (ROA), growth (book-to-market ratio), institutional investors (pension funds holdings), ownership concentration (closely held shares), size (log of total assets), and leverage (total debt to total assets). Firm control for free float (FF) regression (Panel B): blue chip index membership (FTSE100), alternative governance information (asset4 coverage), stock price volatility (StD of monthly stock returns), accounting performance (ROA), size (log of total assets), leverage (total debt to total assets), analyst following, and dividends per share. Firm control for governance (GOV) regression (Panel C): size (log of total assets), growth (one-year change in net sales), accounting performance (ROA), blue chip index membership (FTSE100), firm valuation (Tobin's Q), analyst following, institutional investments (pension funds holdings), ownership concentration (closely held shares), and leverage (total debt to total assets). Firm control for absolute Discretionary Accruals (ADAC) regression (Panel D): size (log of total assets), blue chip index membership (FTSE100), analyst following, institutional investments (pension funds holdings), ownership concentration (closely held shares), loss reporting, cash from operations, and leverage (total debt to total assets). For detailed information and definitions of the variables, see Appendix 4 - 1. In each Panel, Model 5 and 6 simulate the exogenous shock design based on a sample without the treatment group but including both control groups. In these models, SPILLOVER is identical to POST $\times$ TREATED in terms of construction (with Control Group 2 as simulated Treatment Group and Control Group 1 as the simulated Control Group). Thus, the coefficient estimate on SPILLOVER captures any spillover effects on the second original control group (constantly covered firms) due to the exogenous shock in the original treatment group. The regression models contain industry- and yearfixed effects, and have standard errors which are heteroskedasticity robust and one-way clustered at firm level. Alternatively to industry-fixed effects and the inclusion of TREATED, I additionally estimate the regression with firm-fixed (as indicated in Table 4 - 5). Detailed results of the estimated regressions are provided in Appendix 4 - 5. Reported values: coefficient (t-value) $* * *(* *)(*)$ indicates significance levels at $1 \%(5 \%)$ $(10 \%)$, two-tailed.

\subsubsection{Additional Analyses}

\section{Spillover Effects}

Table 4 - 5 provides additional auxiliary regressions on both control groups ('Control $1 \&$ Control 2'). The rationale behind that is to examine any spillover effects on the second control 
group (i.e., constantly covered firms) due to the exogenous increase in ISS coverage. Analogous to possible spillover effects for voluntary IFRS adopters after mandatory IFRS adoption due to increased comparability (e.g., Daske et al., 2008, pp. 1088-1089), constantly covered firms might be likewise affected by an increase in ISS coverage. An extended ISS coverage, for example, might be beneficial for any governance-related benchmark and peergroup analysis due to increased sample size power. Based on a sample of all control firms, the variable SPILLOVER takes the value of one if the firm belongs to the second control group in the period after 2005, and zero otherwise. Thus, the coefficient estimate on SPILLOVER captures any spillover effects on the second control group (i.e., constantly covered firms) due to the exogenous shock in the original treatment group. Although insignificant in the analyst following and free float regressions (Panel A and B, Table 4 - 5), the coefficient estimates on SPILLOVER in the earnings management regression become significant at conventional levels and obtain negative signs (Panel D, Table 4 - 5). These findings might indicate some spillover effects with respect to changes in earnings management and potentially explain the insignificant findings of the second DiD regression model in the earnings management specification ('Treatment \& Control 2', Panel D, Table 4 - 5).

\section{Validity of Exogenous Shock Event}

Following Irani and Oesch (2013), I challenge the validity of the quasi-natural experiment by re-estimating the main DiD regressions (Table 4 - 5) based on a restricted sample covering only the two years prior to the original exogenous shock in 2005 (restricted sample from 2003 to 2004). Depending on the underlying control group, the variables POST $\times$ TREATED and ANTE $\times$ TREATED in the re-estimated DiD regressions simulate an exogenous shock in 2004. Given that the parallel trends assumption holds between the treatment and the control group for the period prior to the original exogenous shock in 2005, I do not expect the coefficient estimates on POST $\times$ TREATED and ANTE $\times$ TREATED to become significant in the reestimated $\mathrm{DiD}$ regressions. In particular, the parallel trends assumption demands that my outcome variables (i.e., analyst following, free float, governance quality, and earnings management) remain parallel and constant across the treatment and the control group prior to the original exogenous shock in 2005. Consistent with the validity of the exogenous shock event, untabulated results reveal that in the re-estimated analyst following (AF), governance (GOV), and earnings management (ADAC) DiD regressions, the respective coefficient 
estimates remain insignificant. However, the findings for the free float (FF) regressions are mixed (POST $\times$ TREATED becomes significant at a 5\% level). Thus, the free float regression results have to be interpreted with caution (Table $4-5$, Panel B). ${ }^{96}$

\section{Real Earnings Management}

To extend the scope of my earnings management proxy, I re-estimate the earnings management DiD regressions (Table 4 - 5, Panel D) based on a measure of real earnings management. Alternatively to the employed discretionary accrual proxy (ADAC), I use a summary measure based on abnormal production costs and abnormal discretionary expenses to assess real earnings management activities (Roychowdhury, 2006; Garcia Lara et al., 2012). ${ }^{97}$

Whether the coverage by governance analysts ultimately affects both accrual-based and real earnings management is a priori unclear. Prior earnings management studies, for example, document that managers have started to substitute accruals manipulation by real earnings management activities after the introduction of the Sarbanes Oxley Act (Cohen et al., 2008; Roychowdhury, 2006). In a recent study, Garcia Lara et al. (2012) show that - given constant incentives to engage in earnings management - firms shift from accrual-based to (potentially more costly) real earnings management if accounting conservatism constrains the extent of accruals manipulation. Consistent with that, Zang (2012) documents that firms choose the level of accruals manipulation in accordance to the realized manipulation of real activities.

Untabulated results reveal that across all model specifications ('Treatment \& Control 1', 'Treatment \& Control 2', with and without firm-fixed effects) the coefficient estimates capturing the DiD effect (POST×TREATED and ANTE×TREATED) remain insignificant. Thus, these findings do not suggest that real earnings management - compared to accrualbased earnings management - is likewise affected by the exogenous increase in governance analyst coverage. ${ }^{98}$

\footnotetext{
${ }^{96}$ See Appendix 4 - 2.

${ }^{97}$ See Appendix 4 - 3, Panel A for details on the estimation process of real earnings management.

${ }^{98}$ See Appendix 4 - 3.
} 


\section{OLS Regression and Two-Stage Heckman Modeling}

Finally, I estimate ordinary OLS regressions for comparability reasons. To address the selfselection (endogeneity) bias in the OLS regression model, I follow the two-stage Heckman procedure (e.g., Lennox et al., 2012, p. 591-592) and include the inverse Mills (MILLS) ratio from a first-stage probit regression into the main OLS regression model as an additional explanatory variable. ${ }^{99}$ Thus, I estimate the following model:

$\mathrm{VI}_{\mathrm{it}}=\alpha+\gamma_{1}$ ISS $_{-}$COV $_{\mathrm{it}}+\gamma_{2}$ MILLS $_{\mathrm{it}}+\sum \gamma_{2}$ FIRM_CONTROL $_{\mathrm{it}}+\sum \gamma_{3} \mathrm{YEAR}_{\mathrm{it}}+\varepsilon$

The OLS regressions employ the same set of dependent variables (the same variables of interests - VI) as well as firm control variables as the original DiD models (Table 4 - 5). They further contain year- and firm-fixed effects as well as heteroskedasticity-robust and firm-level clustered standard errors. ISS_COV is the model's main interest variable and indicates whether or not a firm is covered by ISS governance analysts (CGQ ratings). Following the first three predictions (the last prediction) and employing the respective dependent variable in the OLS model, I expect positive (negative) and significant coefficient estimates on ISS_COV.

Untabulated results appear to be in line with my original DiD findings. In particular, the coverage by ISS analysts is significantly and positively (negatively) associated with analyst following, free float, and governance quality (earnings management). ${ }^{100}$ Likewise, OLS results do not suggest that ISS coverage is correlated with real earnings management. Compared to the DiD findings, the OLS results, however, overestimate (underestimate) the governance analyst coverage effect on accrual-based earnings management (analyst following and governance quality).

Nevertheless, as outlined in section 4.4.2, these OLS results are difficult to interpret due to the potential endogenous relationship between governance analyst coverage and various firm characteristics, e.g., index membership and institutional investments. As these firm characteristics are in turn most likely related to my dependent variables, i.e., analyst

\footnotetext{
${ }^{99}$ I use index membership (FTSE All Share Index) and dividend yield (DIV_YIELD) as exclusion restrictions and expect that these variables have no first-order effect on my dependent variables, but rather serve as good predictors of ISS coverage. I acknowledge, however, that the quality (respectively the fully exogenous nature) of my selected exclusion restrictions is potentially weak. Partially (or even fully) endogenous exclusion restrictions are an issue that plagues virtually all empirical accounting studies employing selection models (e.g., BoerschSupan and Koeke, 2002; Beiner et al., 2006). See Appendix 4 - 4, Panel A for details on the two-stage Heckman procedure.

${ }^{100}$ However, the coefficient estimate on ISS_COV in the governance regression remains insignificant when including the MILLS ratio from the first-stage Heckman Model. See Appendix 4 - 4.
} 
following, free float, governance quality, and accounting quality, OLS results are prone to endogeneity concerns. IV methods - like two-stage Heckman modeling with exclusion restrictions as instruments in the first stage - are potentially able to address these concerns. However, it is difficult to find appropriate instruments in most empirical setups (e.g., Larcker and Rusticus, 2010, pp. 187, 196, 201; Ertugrul and Hegde, 2009, pp. 157-158; BoerschSupan and Koeke, 2002, p. 321). In a recent literature survey, Lennox et al. (2012, p. 590) criticize the inflationary use of IV models in empirical accounting research by stating that "[a] surprising number of studies (14 of 75) fail to have any exclusions, and other studies ( 7 out of 75) do not report the first stage model, making it impossible to determine if they imposed exclusion restrictions. Moreover, very few studies provide any theoretical or economic justification for their chosen restrictions."

\subsection{Conclusion}

Using a quasi-natural experiment that exploits an exogenous shock in the UK ISS governance analyst coverage, I provide evidence on the role of non-financial governance analysts and their relevance to the capital market. Specifically, I examine potential economic consequences of governance analyst coverage by focusing on two different groups (financial analysts and investors) as well as on two firm-level mechanisms (corporate governance quality and earnings management) which are potentially affected by the presence of governance analysts.

Overall, my results - based on a twofold $\mathrm{DiD}$ regression design - suggest that the exogenous increase in ISS analyst coverage results (1) in increasing analyst following, (2) weakly in increasing free float, (3) in improvements in firm-level corporate governance, and (4) weakly in decreasing accruals manipulations. These findings are robust to endogeneity concerns. In line with the paper's predictions, they suggest that financial analysts, investors, and managers respond to changes in governance analyst coverage. Specifically, the findings are consistent with the notion that the financial analysts' marginal costs to cover a firm decrease after the exogenous increase in ISS coverage. They imply further that executives and board members feel potentially pressured by the presence of governance analysts to improve firm-level governance quality, if necessary. Overall, my results suggest that governance analysts might serve as economically meaningful information intermediaries by enhancing a firm's information environment and by promoting external monitoring to managers.

The paper's findings contribute to the extant literature in several ways. First, this is to 
my knowledge the first paper which provides evidence on the coverage effects of governance analysts. In doing so, it extends research on financial analysts by introducing 'another' type of analysts, i.e., non-financial corporate governance analysts, and by providing evidence on potential consequences of governance analyst coverage (including interrelations between governance analysts and financial analysts). These insights are potentially important as prior research on analysts has primarily focused on the role of sell-side equity analysts. By examining the coverage effects of governance analysts, my paper additionally contributes to the limited but growing research addressing issues like the growth and impact of commercial corporate governance rating vendors, the role and regulation as well as the usefulness of proxy advisors, or the usefulness of commercial governance ratings to investors. Since these studies particularly argue about the economic vindication (or usefulness) of proxy advisors and governance rating vendors (and their ratings), empirical evidence on potential consequences of governance analyst coverage provides additional insights into the usefulness of governance advisory on capital markets. Finally, my findings potentially contribute to the literature on the governance role of institutional investors. Since governance agencies are primarily paid by institutional investors in order to enhance the firm's information environment with respect to governance issues, my paper adds to this research by providing evidence on a potential channel in which the presence of such investors might affect the firm's information environment.

My findings, however, are subject to several limitations. Owing to the exogenous shock setting, I only investigate the coverage effects of one particular governance agency (namely ISS), for one particular market (the UK), and for a specific time period (2004 to 2006). With the paper's quasi-natural experimental setting, internal validity increases at the expense of external validity. As in most empirical studies, the findings of this paper further depend on the validity of the employed empirical proxies. Prior studies, for example, discuss the construct validity of discretionary accruals (e.g., Collins et al., 2012) and corporate governance ratings (e.g., Larcker et al., 2007), and point out that prior findings are sensitive to the chosen measurement approach. In addition, my findings depend on the extent to which my affected outcome variables are able to respond in a timely manner to the exogenous shock in 2005 . However, potential stickiness concerns (e.g., with respect to governance choices or accounting choices) work against the probability to find any effects and thus rather strengthen the robustness of the paper's findings. 
Overall, my findings create various research opportunities. Future work may consider governance analysts from different agencies, for different markets, and different time periods. In the absence of any natural experiments (i.e., exogenous shock in coverage), it might be worth to study first-time coverage effects for firms in a particular market. Likewise, evidence from a cross-country setting might provide additional insights. It is plausible to assume that institutional features, like enforcement strength or investor protection standards, affect the information role of governance analysts. 


\subsection{Appendix}

Appendix 4 - 1: Definition of Variables

\begin{tabular}{|c|c|c|}
\hline SHORT CUT & VARIABLE & DEFINITION \\
\hline \multicolumn{3}{|c|}{ Earnings Management Proxy } \\
\hline ADAC* & $\begin{array}{l}\text { Absolute discretionary } \\
\text { accruals }\end{array}$ & $\begin{array}{l}A D A C \text { are the absolute residuals from an extended (performance \& } \\
\text { growth adj.) cross-sectional modified Jones model (CMJM) based } \\
\text { on the cash flow approach and total accruals }\end{array}$ \\
\hline $\mathrm{TAC}^{*}$ & Total accruals & $\begin{array}{l}T A C \text { is total accruals }=\text { net income }(\text { wc } 01751)-\text { cash from } \\
\text { operations }(\text { wc } 04860)\end{array}$ \\
\hline $\mathrm{REV}^{*}$ & Revenues & $R E V$ is net sales of revenues ( $\mathrm{wc} 01001)$ \\
\hline REC* & Receivables & $R E C$ is receivables (wc02051) \\
\hline PPE & PPE & $P P E$ is property, plant \& equipment $(\mathrm{wc} 02301)$ \\
\hline ROA* & Return-on-assets & $\begin{array}{l}R O A \text { is return-on-assets as EBIT (wc18191) scaled by total assets } \\
\text { (wc02999) }\end{array}$ \\
\hline GROWTH & Growth in net sales & 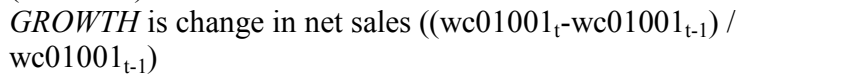 \\
\hline TA & Total assets & $T A$ is total assets (wc02999) \\
\hline
\end{tabular}

Coverage by Governance Analysts

\begin{tabular}{|c|c|c|}
\hline ISS_COV & $\begin{array}{l}\text { Coverage by } \\
\text { Governance Agency }\end{array}$ & $\begin{array}{l}\text { ISS_COV is a dummy variable indicating whether a firm is covered } \\
\text { by ISS, or not. }\end{array}$ \\
\hline \multicolumn{3}{|c|}{ Dependent Variables (excluding DAC) } \\
\hline $\begin{array}{l}\text { AF } \\
\text { FF } \\
\text { GOV }\end{array}$ & $\begin{array}{l}\text { Analyst following } \\
\text { Free float } \\
\text { Governance Score }\end{array}$ & $\begin{array}{l}A F \text { is the number of analyst following (flne) } \\
F F \text { measures free float of outstanding shares (noshff). } \\
G O V \text { is a corporate governance score provided by ASSET4 } \\
\text { (cgvscore) }\end{array}$ \\
\hline \multicolumn{3}{|c|}{ Firm Control Variables } \\
\hline PENSION & $\begin{array}{l}\text { Pension funds } \\
\text { holdings }\end{array}$ & Pension is number of shares hold by pension funds (noshpf) \\
\hline LOSS & Loss reporting & $\begin{array}{l}\text { LOSS stands for loss reporting and indicates as a dummy variable } \\
\text { with } 1 \text { if the firm reports a loss in year } \mathrm{t}-1\left(\mathrm{wc} 01751_{\mathrm{t}-1}<0\right)\end{array}$ \\
\hline SIZE & $\begin{array}{l}\text { Log of market value } \\
\text { of equity }\end{array}$ & $\begin{array}{l}\text { SIZE if the natural logarithm of market value of equity (EURO) } \\
\text { (xmve) }\end{array}$ \\
\hline LEV & Leverage & $\begin{array}{l}L E V \text { is the accounting leverage as total liabilities (wc03351) to } \\
\text { fiscal years average total assets (dwta) }\end{array}$ \\
\hline $\mathrm{CFO}$ & $\begin{array}{l}\text { Cash from } \\
\text { operations }_{1}\end{array}$ & $\begin{array}{l}C F O_{I}=\text { net cash flow - operating activities (wc04860) deflated by } \\
\text { total assets (wc02999) }\end{array}$ \\
\hline OWNER & Ownership & Owner as ownership - closely held shares (wc08021) \\
\hline SD_CFO & $\begin{array}{l}\text { Volatility of } \\
\text { business }\end{array}$ & $\begin{array}{l}S D \_C F O \text { is volatility of business as the standard deviation of cash } \\
\text { from operations (wc04860) over the sample period ( } 2003 \text { to } 2007)\end{array}$ \\
\hline FTSE100 & Index membership & FTSE100 indicates FTSE100 index membership (wc05661) \\
\hline Q & Tobin’s Q & $\begin{array}{l}Q \text { measures firm value and equals the book value of total assets } \\
\text { (dwta) + market value of common shares (mv) - book value of } \\
\text { common shares (dwse) divided by book value of total assets (dwta). }\end{array}$ \\
\hline CAP_INT & PPE to total assets & $\begin{array}{l}\text { CAP_INT (capital intensity) is property, plant \& equipment } \\
\text { (wc02501) to total assets (wc02999). }\end{array}$ \\
\hline ASSET4_COV & ASSET4 coverage & $\begin{array}{l}\text { ASSET4_COV is a dummy variable indicating with } 1 \text { and } 0 \text { whether } \\
\text { a firm is covered by ASSET } 4 \text { governance score }\end{array}$ \\
\hline GROWTH & Change in net sales & GROWTH is one-year change in net sales (wc01001) \\
\hline ROA & Return-on-assets & $\begin{array}{l}\text { ROA is defined as EBIT (wc18191) deflated by total assets } \\
\text { (wc02999) }\end{array}$ \\
\hline BTM & $\begin{array}{l}\text { Book-to-Market } \\
\text { ratio }\end{array}$ & $\begin{array}{l}\text { BTM is defined as common equity (wc03501) deflated by market } \\
\left.\text { capitalization (wc } 05001 *_{\text {nosh }}\right)\end{array}$ \\
\hline SD_STOCK & Stock volatility & $\begin{array}{l}S D \_S T O C K \text { is the yearly average standard deviation of monthly } \\
\text { stock returns (based on wc } 05015-\mathrm{wc} 05070 \text { ) }\end{array}$ \\
\hline $\mathrm{BC}$ & $\begin{array}{l}\text { Brokerage } \\
\text { commission }\end{array}$ & $\begin{array}{l}B C \text { stands for brokerage commission and is defined as the firm's } \\
\text { inverse stock price }\left(-1^{*} \mathrm{wc} 05001\right)\end{array}$ \\
\hline DPS & Dividend per share & $D P S$ is dividends per share (wc05101) \\
\hline
\end{tabular}

* Winsorized by extreme percentiles ( $1 \%$ level) to control for outliers (yearly based). 
Appendix 4 - 2: Validity of Natural Experiment

\begin{tabular}{|c|c|c|c|c|c|c|c|}
\hline & \multicolumn{7}{|c|}{ Sample: 2003 to 2004 (without the original exogenous shock) } \\
\hline & \multicolumn{2}{|c|}{ Analyst Following } & \multicolumn{2}{|c|}{ Free Float } & \multirow{2}{*}{$\begin{array}{c}\text { GOV } \\
\text { Treatment } \\
\& \text { Control } 2\end{array}$} & \multicolumn{2}{|c|}{ ADAC } \\
\hline & $\begin{array}{l}\text { Treatment } \\
\& \text { Control } 1\end{array}$ & $\begin{array}{c}\text { Treatment } \\
\& \text { Control } 2\end{array}$ & $\begin{array}{l}\text { Treatment } \\
\& \text { Control } 1\end{array}$ & $\begin{array}{l}\text { Treatment } \\
\& \text { Control } 2\end{array}$ & & $\begin{array}{l}\text { Treatment } \\
\& \text { Control } 1\end{array}$ & $\begin{array}{l}\text { Treatment } \\
\& \text { Control } 2\end{array}$ \\
\hline P_TREATED & $\begin{array}{l}-.2091 \\
(-0.62)\end{array}$ & & $\begin{array}{c}11.45 * * \\
(2.05)\end{array}$ & & & $\begin{array}{l}.0006 \\
(0.03)\end{array}$ & \\
\hline A_TREATED & & $\begin{array}{l}.6067 \\
(0.79)\end{array}$ & & $\begin{array}{c}7.49 \\
(1.56)\end{array}$ & $\begin{array}{c}6.65 \\
(0.61)\end{array}$ & & $\begin{array}{l}.0057 \\
(0.29)\end{array}$ \\
\hline F. CONTROL & Yes & Yes & Yes & Yes & Yes & Yes & Yes \\
\hline YEAR fe & Yes & Yes & Yes & Yes & Yes & Yes & Yes \\
\hline IND fe & No & No & No & No & No & No & No \\
\hline FIRM fe & Yes & Yes & Yes & Yes & Yes & Yes & Yes \\
\hline Sample Size & 677 & 349 & 702 & 351 & 127 & 763 & 354 \\
\hline Adj. $\mathrm{R}^{2}$ & .8301 & .8991 & .2876 & .3935 & .7117 & .5002 & .3215 \\
\hline
\end{tabular}

Notes: The sample period is between 2003 and 2004 (without the original exogenous shock in ISS coverage). The underlying basic regression model is:

$$
\begin{gathered}
\mathrm{VI}_{\mathrm{it}}=\alpha+\gamma_{1} \text { TREATED }_{\mathrm{it}}+\gamma_{2} \text { POST } \times \text { TREATED }_{\text {it }}\left[\gamma_{2} \text { ANTE } \times \text { TREATED }_{\text {it }}\right]+\sum \gamma_{2} \text { FIRM_CONTROL }_{\text {it }} \\
+\sum \gamma_{3} \text { YEAR }_{\text {it }}+\sum \gamma_{4} \text { INDUSTRY }_{\text {it }}+\varepsilon
\end{gathered}
$$

TREATED is a dummy variable indicating the treatment group. Depending on the underlying control group, the coefficient estimates on the variables POST $\times$ TREATED and ANTE $\times$ TREATED capture the difference-indifference effect (for definitions of treatment and control group, see Table 4 - 1). Firm control for analyst following (AF) regression: blue chip index membership (FTSE100), alternative governance information (asset4 coverage), capital intensity (PPE to total assets), volatility of business (StD of cash from operations), stock price volatility (StD of monthly stock returns), brokerage commission (inverse stock price), accounting performance (ROA), growth (book-to-market ratio), institutional investors (pension funds holdings), ownership concentration (closely held shares), size (log of total assets), and leverage (total debt to total assets). Firm control for free float (FF) regression: blue chip index membership (FTSE100), alternative governance information (asset4 coverage), stock price volatility (StD of monthly stock returns), accounting performance (ROA), size (log of total assets), leverage (total debt to total assets), analyst following, and dividends per share. Firm control for governance (GOV) regression: size (log of total assets), growth (one-year change in net sales), accounting performance (ROA), blue chip index membership (FTSE100), firm valuation (Tobin's Q), analyst following, institutional investments (pension funds holdings), ownership concentration (closely held shares), and leverage (total debt to total assets). Firm control for absolute Discretionary Accruals (ADAC) regression: size (log of total assets), blue chip index membership (FTSE100), analyst following, institutional investments (pension funds holdings), ownership concentration (closely held shares), loss reporting, cash from operations, and leverage (total debt to total assets). For detailed information and definitions of the variables, see Appendix $4-1$. The regression models contain industry- and year-fixed effects (as indicated with YEAR FE and IND FE), and have standard errors which are heteroskedasticity robust and one-way clustered at firm level. Alternatively to industry-fixed effects and the inclusion of TREATED, I additionally estimate the regression with firm-fixed effects (as indicated in Table 4 - 5 with FIRM fe). Reported values: coefficient (t-value) $* * *(* *)(*)$ indicates significance levels at $1 \%$ $(5 \%)(10 \%)$, two-tailed. 


\section{Appendix 4 - 3: Real Earnings Management}

Panel A. Estimation of Real Earnings Management

Following Roychowdhury (2006) and Garcia Lara et al. (2012), I use a summary measure based on abnormal production costs and abnormal discretionary expenses to assess real earnings management activities. Both measures are adjusted by one-year lagged ROA and sales growth in the estimation process to control for firm performance and growth (Garcia Lara et al., 2012, pp. 13-14). To estimate abnormal production costs, I use the following regression model for each two-digit SIC industry group and year (with at least 15 observations):

$$
\begin{aligned}
\mathrm{PROD}_{\mathrm{it}} / \mathrm{TA}_{\mathrm{it}-1}= & \delta_{1}+\delta_{2}\left(1 / \mathrm{TA}_{\mathrm{it}-1}\right)+\delta_{3}\left(\mathrm{SALES}_{\mathrm{it}} / \mathrm{TA}_{\mathrm{it}-1}\right)+\delta_{4}\left(\Delta \mathrm{SALES}_{\mathrm{it}} / \mathrm{TA}_{\mathrm{it}-1}\right) \\
& +\delta_{5}\left(\Delta \mathrm{SALES}_{\mathrm{it}-1} / \mathrm{TA}_{\mathrm{it}-1}\right)+\delta_{6}\left(\mathrm{ROA}_{\mathrm{it}-1}\right)+\delta_{7}(\mathrm{GROWTH})+\varepsilon_{\mathrm{i}}
\end{aligned}
$$

The dependent variable PROD stands for production costs and is measured as the sum of costs of goods sold and the change in inventory during the respective year. SALES stands for firm's net sales, GROWTH measures current one-year growth in sales, and ROA is return-on-assets. The residuals of regression model (i) are the abnormal production costs (APROD) with higher values indicating more real earnings management.

To estimate abnormal discretionary expenses, I use the following regression model for each two-digit SIC industry group and year (with at least 15 observations):

$$
\begin{aligned}
\operatorname{DEXP}_{\mathrm{it}} / \mathrm{TA}_{\mathrm{it}-1}= & \varphi_{1}+\varphi_{2}\left(1 / \mathrm{TA}_{\mathrm{it}-1}\right)+\varphi_{3}\left(\mathrm{SALES}_{\mathrm{it}-1} / \mathrm{TA}_{\mathrm{it}-1}\right)+\varphi_{6}\left(\mathrm{ROA}_{\mathrm{it}-1}\right)+\varphi_{7}(\mathrm{GROWTH}) \\
& +\varepsilon_{\mathrm{i}}
\end{aligned}
$$

The dependent variable DEXP represents discretionary expenses and is defined as the sum of selling, general \& administrative (SG\&A) expenses, R\&D expenses, and advertising expenses. SALES, ROA, and GROWTH are defined as for model (4). The residuals of regression model (ii) are the abnormal discretionary expenses (ADEXP) with lower values indicating more income increasing real earnings management. Following prior literature, I aggregate the two variables into one proxy (REM) to measure real earnings management activities (e.g., Garcia Lara et al., 2012, p. 14; Cohen and Zarowin, 2010, p. 9). In doing so, I

\begin{tabular}{|c|c|c|c|c|c|c|c|}
\hline & \multirow{3}{*}{$\begin{array}{l}\text { Pred. } \\
\text { Sign }\end{array}$} & \multicolumn{6}{|c|}{ Dependent variable: Real Earnings Management } \\
\hline & & \multicolumn{2}{|c|}{ Treatment \& Control 1} & \multicolumn{2}{|c|}{ Treatment \& Control 2} & \multicolumn{2}{|c|}{ Control 1 \& Control 2} \\
\hline & & Model 1 & Model 2 & Model 3 & Model 4 & Model 5 & Model 6 \\
\hline POST_TREATED & - & $\begin{array}{l}-.0742 \\
(-1.42)\end{array}$ & $\begin{array}{l}.0006 \\
(0.01)\end{array}$ & & & & \\
\hline ANTE_TREATED & + & & & $\begin{array}{l}.0022 \\
(0.05)\end{array}$ & $\begin{array}{l}-.0008 \\
(-0.02)\end{array}$ & & \\
\hline SPILLOVER & & & & & & $\begin{array}{l}-.0230 \\
(-0.49)\end{array}$ & $\begin{array}{l}.0105 \\
(0.19)\end{array}$ \\
\hline \multicolumn{2}{|l|}{ FIRM CONTROL VARs } & Yes & Yes & Yes & Yes & Yes & Yes \\
\hline \multicolumn{2}{|l|}{ YEAR fixed effect } & Yes & Yes & Yes & Yes & Yes & Yes \\
\hline \multicolumn{2}{|l|}{ IND fixed effect } & Yes & No & Yes & No & Yes & No \\
\hline \multicolumn{2}{|l|}{ FIRM fixed effect } & No & Yes & No & Yes & No & Yes \\
\hline \multicolumn{2}{|l|}{ Sample Size } & 870 & 870 & 451 & 451 & 781 & 781 \\
\hline \multicolumn{2}{|l|}{ Adj. $\mathrm{R}^{2}$} & .1056 & .8127 & .1745 & .8547 & .0671 & .7923 \\
\hline
\end{tabular}
define REM as the sum of APROD and ( $-1^{*}$ ADEXP). Thus, higher values of REM indicate more real earnings management.

Panel B. DiD Regression Results

Notes: The underlying basic regression model is:

$$
\begin{gathered}
\text { REM }_{\text {it }}=\alpha+\gamma_{1} \text { TREATED }_{\text {it }}+\gamma_{2} \text { POST } \times \text { TREATED }_{\text {it }}\left[\gamma_{2} \text { ANTE } \times \text { TREATED }_{i t}\right]+\sum \gamma_{2} \text { FIRM_CONTROL }_{i t} \\
+\sum \gamma_{3} \text { YEAR }_{\text {it }}+\sum \gamma_{4} \text { INDUSTRY }_{\text {it }}+\varepsilon
\end{gathered}
$$

TREATED is a dummy variable indicating the treatment group. Depending on the underlying control group, the coefficient estimates on the variables POST $\times$ TREATED and ANTE $\times$ TREATED capture the difference-indifference effect (for definitions of treatment and control group, see Table 4 - 1). REM (real earnings management) is a proxy based on abnormal production costs and abnormal discretionary expenses (Garcia Lara et al., 2012; Roychowdhury, 2006). Firm control includes: size (log of total assets), blue chip index membership (FTSE100), analyst following, institutional investments (pension funds holdings), ownership concentration (closely held shares), loss reporting, cash from operations, and leverage (total debt to total assets). For detailed information and definitions of the variables, see Appendix $4-1$. Model 5 and 6 simulate the exogenous shock design based on a sample without the treatment group but including both control groups. In these models, SPILLOVER is identical to POST $\times$ TREATED in terms of construction (with Control Group 2 as simulated Treatment Group and Control Group 1 as the simulated Control Group). Thus, the coefficient estimate on SPILLOVER captures any spillover effects on the second original control group (constantly covered firms) due to the exogenous shock in the original treatment group. The regression models contain industry- and year-fixed 
effects, and have standard errors which are heteroskedasticity robust and one-way clustered at firm level. Alternatively to industry-fixed effects and the inclusion of TREATED, I additionally estimate the regression with firm-fixed effects (as indicated). Reported values: coefficient (t-value) $* * *(* *)(*)$ indicates significance levels at $1 \%(5 \%)(10 \%)$, two-tailed. 


\section{Appendix 4 - 4: Naïve OLS Regressions (with and without Heckman Modeling)}

Panel A. Two-Stage Heckman Modeling

To address a potential self-selection (endogeneity) bias in the basic OLS regression model, I follow the twostage Heckman procedure (e.g., Lennox et al., 2012, p. 591-592) and include the inverse Mills ratio from a first-stage probit regression into the main OLS regression model as an additional explanatory variable. In doing so, I use the following first-stage probit regression model:

$$
\begin{gathered}
\text { Probit(ISS_COVERAGE) })_{\text {it }}=\alpha_{1}+\sum \alpha_{2} \text { EXCLUSION }_{\text {it }}+\sum \alpha_{3} \text { FIRM_CONTROL }_{\text {it }} \\
+\sum \alpha_{4} \text { YEAR }_{\text {it }}+\sum \alpha_{5} \text { INDUSTRY }_{\text {it }}+\varepsilon
\end{gathered}
$$

ISS_COVERAGE is a dummy variable indicating whether or not a firm is covered by ISS (CGQ rating). The vector of firm characteristics, the year and industry-fixed effects, and the standard errors are defined as for regression models 3 to 6. EXCLUSION represents a vector of exclusion restrictions to specify the first-stage probit regression. Lennox et al. (2012, p. 592) state that "the choice of exclusion restriction is vital for implementing the selection model in a way that convincingly controls for endogeneity" in the second stage of the Heckman procedure. I use index membership (FTSE All Share Index) and dividend yield (DIV_YIELD) as my exclusion restrictions, and expect that these variables criteria have no first-order effect on my dependent variables, but rather serve as good predictors of ISS coverage. However, I acknowledge that the quality (respectively the fully exogenous nature) of my selected exclusion restrictions is potentially weak. Partially (or even fully) endogenous exclusion restrictions are an issue that plagues virtually all empirical accounting studies employing selection models (e.g., Boersch-Supan and Koeke, 2002; Beiner et al., 2006). In a recent survey of prior empirical accounting studies using selection models, Lennox et al. (2012, p. 590) note that "[a] surprising number of studies (14 of 75) fail to have any exclusions, and other studies (7 out of 75) do not report the first stage model, making it impossible to determine if they imposed exclusion restrictions. Moreover, very few studies provide any theoretical or economic justification for their chosen restrictions."

Panel B. Analyst Following, Free Float, and Governance Quality

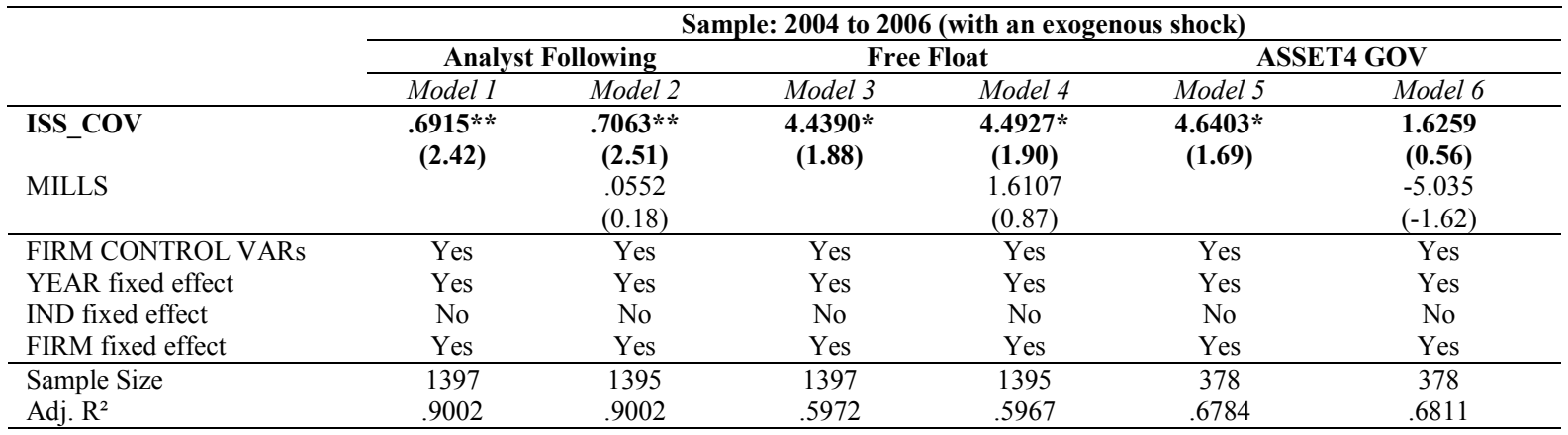

Panel C. Accrual-based and real earnings management

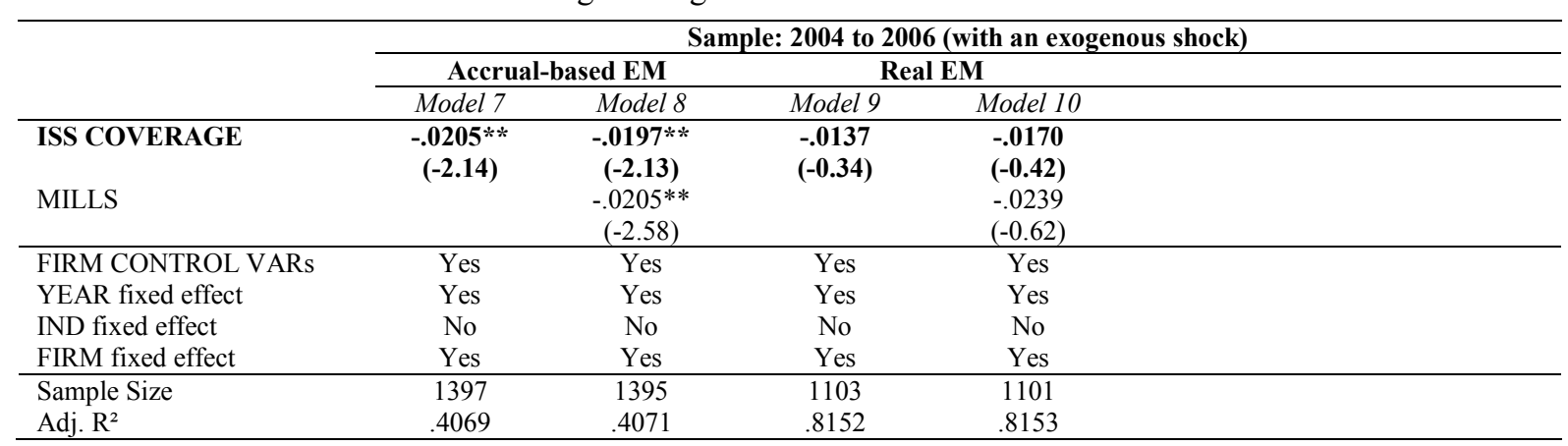

Notes: The underlying basic regression model is:

$\mathrm{VI}_{\mathrm{it}}=\alpha+\gamma_{1}$ ISS COVERAGE $_{\mathrm{it}}+\gamma_{2}$ MILLS $_{\mathrm{it}}+\sum \gamma_{2}$ FIRM_CONTROL $_{\mathrm{it}}+\sum \gamma_{3}$ YEAR $_{\mathrm{it}}+\sum \gamma_{4} \mathrm{IND}_{\mathrm{it}}+\varepsilon$

ISS_COV is a dummy variable indicating whether or not a firm is covered by ISS (CGQ rating). MILLS is the inverse mills ratio from a first stage Heckman regression with the following two exclusion restrictions: dividend yield and FTSE ALL Share Index Membership. Firm control for analyst following (AF) regression: blue chip index membership (FTSE100), alternative governance information (asset4 coverage), capital intensity (PPE to total assets), volatility of business (StD of cash from operations), stock price volatility (StD of monthly stock 
returns), brokerage commission (inverse stock price), accounting performance (ROA), growth (book-to-market ratio), institutional investors (pension funds holdings), ownership concentration (closely held shares), size (log of total assets), and leverage (total debt to total assets). Firm control for free float (FF) regression: blue chip index membership (FTSE100), alternative governance information (asset4 coverage), stock price volatility (StD of monthly stock returns), accounting performance (ROA), size (log of total assets), leverage (total debt to total assets), analyst following, and dividends per share. Firm control for governance (GOV) regression: size (log of total assets), growth (one-year change in net sales), accounting performance (ROA), blue chip index membership (FTSE100), firm valuation (Tobin's Q), analyst following, institutional investments (pension funds holdings), ownership concentration (closely held shares), and leverage (total debt to total assets). Firm control for absolute Discretionary Accruals (ADAC) regression: size (log of total assets), blue chip index membership (FTSE100), analyst following, institutional investments (pension funds holdings), ownership concentration (closely held shares), loss reporting, cash from operations, and leverage (total debt to total assets). For detailed information and definitions of the variables, see Appendix 4 - 1. The regression models contain year- and firm-fixed effects, and have standard errors which are heteroskedasticity robust and one-way clustered at firm level. Reported values: coefficient (t-value) $* * *(* *)(*)$ indicates significance levels at $1 \%(5 \%)(10 \%)$, two-tailed. 
DO CORPORATE GOVERNANCE ANALYSTS MATTER? EVIDENCE FROM A QUASI-NATURAL EXPERIMENT

Appendix 4 - 5: Detailed DiD Regression Analyses (w.r.t. Table 4 - 5)

Panel A. Prediction 1: Governance Analysts and Financial Analysts

\begin{tabular}{|c|c|c|c|c|c|c|c|c|c|}
\hline & \multirow{3}{*}{$\begin{array}{l}\text { Pred. } \\
\text { Sign }\end{array}$} & \multicolumn{8}{|c|}{ Dependent variable: Analyst Following } \\
\hline & & \multicolumn{4}{|c|}{ Treatment Group \& Control Group 1} & \multicolumn{4}{|c|}{ Treatment Group \& Control Group 2} \\
\hline & & Model 1 & Model 2 & Model 3 & Model 4 & Model 5 & Model 6 & Model 7 & Model 8 \\
\hline Intercept & & $\begin{array}{c}2.532 * * * \\
(13.97)\end{array}$ & $\begin{array}{c}2.629^{* * * *} \\
(31.45)\end{array}$ & $\begin{array}{c}-8.829 * * * \\
(-6.65)\end{array}$ & $\begin{array}{c}-9.358 \\
(-1.20) \\
\end{array}$ & $\begin{array}{c}11.742^{* * *} \\
(13.34)\end{array}$ & $\begin{array}{c}7.607 * * * \\
(109.89) \\
\end{array}$ & $\begin{array}{c}-33.023^{* * *} \\
(-7.26) \\
\end{array}$ & $\begin{array}{c}-11.775 \\
(-0.76) \\
\end{array}$ \\
\hline POST & & $\begin{array}{c}-0.707 * * * \\
(-3.82)\end{array}$ & $\begin{array}{c}0.363 * * \\
(2.51)\end{array}$ & (omitted) & (omitted) & & & & \\
\hline ANTE & & & & & & $\begin{array}{l}0.008 \\
(0.02)\end{array}$ & $\begin{array}{l}-0.110 \\
(-0.24)\end{array}$ & (omitted) & (omitted) \\
\hline TREATED & & $\begin{array}{c}1.536^{* * * *} \\
(4.82) \\
\end{array}$ & (omitted) & $\begin{array}{c}-0.701 * * \\
(-2.40) \\
\end{array}$ & (omitted) & $\begin{array}{c}-6.270 * * * \\
(-6.68) \\
\end{array}$ & (omitted) & $\begin{array}{l}-0.540 \\
(-0.90) \\
\end{array}$ & (omitted) \\
\hline POST_TREATED & + & $\begin{array}{c}2.111 * * * \\
(7.47)\end{array}$ & $\begin{array}{c}0.872 * * * \\
(3.17)\end{array}$ & $\begin{array}{c}1.151 * * * \\
(5.10)\end{array}$ & $\begin{array}{c}0.881 \text { *** } \\
(3.23)\end{array}$ & & & & \\
\hline ANTE_TREATED & - & & & & & $\begin{array}{c}-1.412 * * * \\
(-2.99)\end{array}$ & $\begin{array}{c}-1.125 * * \\
(-2.20)\end{array}$ & $\begin{array}{c}-0.962 * * \\
(-2.04)\end{array}$ & $\begin{array}{c}-0.979 * \\
(-1.73)\end{array}$ \\
\hline FTSE100 & & & & $\begin{array}{c}3.148 * * \\
(2.61)\end{array}$ & (omitted) & & & $\begin{array}{c}1.448^{*} \\
(1.73)\end{array}$ & (omitted) \\
\hline ASSET4_COV & & & & $\begin{array}{c}2.282 * * * \\
(5.27)\end{array}$ & (omitted) & & & $\begin{array}{l}0.739 \\
(1.35)\end{array}$ & $\begin{array}{l}-0.290 \\
(-0.27)\end{array}$ \\
\hline PPE_TA & & & & $\begin{array}{l}0.216 \\
(0.44)\end{array}$ & $\begin{array}{l}-1.395 \\
(-0.52)\end{array}$ & & & $\begin{array}{l}0.208 \\
(0.20)\end{array}$ & $\begin{array}{l}-2.608 \\
(-0.76)\end{array}$ \\
\hline ВТМ & & & & $\begin{array}{l}-0.148 \\
(-0.82)\end{array}$ & $\begin{array}{l}-0.047 \\
(-0.35)\end{array}$ & & & $\begin{array}{l}0.125 \\
(0.32)\end{array}$ & $\begin{array}{l}-0.243 \\
(-0.63)\end{array}$ \\
\hline $\mathbf{P F}$ & & & & $\begin{array}{l}-0.007 \\
(-0.43)\end{array}$ & $\begin{array}{l}0.001 \\
(0.06)\end{array}$ & & & $\begin{array}{l}0.022 \\
(1.30)\end{array}$ & $\begin{array}{l}-0.002 \\
(-0.13)\end{array}$ \\
\hline SD_STOCK & & & & $\begin{array}{l}0.388 \\
(0.34)\end{array}$ & $\begin{array}{l}1.162 \\
(0.82)\end{array}$ & & & $\begin{array}{l}3.063 \\
(1.01)\end{array}$ & $\begin{array}{l}2.213 \\
(0.66)\end{array}$ \\
\hline BC & & & & $\begin{array}{l}-0.000 \\
(-0.53)\end{array}$ & $\begin{array}{l}-0.000 \\
(-0.16)\end{array}$ & & & $\begin{array}{c}-0.001 * \\
(-1.91)\end{array}$ & $\begin{array}{l}-0.001 \\
(-0.80)\end{array}$ \\
\hline OWNER & & & & $\begin{array}{c}-0.009^{*} \\
(-1.90)\end{array}$ & $\begin{array}{l}-0.007 \\
(-1.03)\end{array}$ & & & $\begin{array}{c}-0.029 * * * \\
(-2.97)\end{array}$ & $\begin{array}{l}0.006 \\
(0.48)\end{array}$ \\
\hline SIZE & & & & $\begin{array}{c}0.964 * * * \\
(8.99)\end{array}$ & $\begin{array}{l}1.100 \\
(1.59)\end{array}$ & & & $\begin{array}{c}2.779 * * * \\
(8.96)\end{array}$ & $\begin{array}{c}1.451 \\
(1.27)\end{array}$ \\
\hline LEV & & & & $\begin{array}{l}-0.344 \\
(-0.66)\end{array}$ & $\begin{array}{l}0.158 \\
(0.21)\end{array}$ & & & $\begin{array}{l}-0.357 \\
(-0.22)\end{array}$ & $\begin{array}{l}0.067 \\
(0.04)\end{array}$ \\
\hline SD_CFO & & & & $\begin{array}{l}0.260 \\
(1.19)\end{array}$ & (omitted) & & & $\begin{array}{c}16.922 * * * \\
(3.42)\end{array}$ & (omitted) \\
\hline ROA & & & & $\begin{array}{l}-0.155 \\
(-0.48) \\
\end{array}$ & $\begin{array}{l}0.288 \\
(0.46) \\
\end{array}$ & & & $\begin{array}{c}3.529^{*} \\
(1.86) \\
\end{array}$ & $\begin{array}{r}-0.843 \\
(-0.54) \\
\end{array}$ \\
\hline YEAR fixed effect & & No & No & Yes & Yes & No & No & Yes & Yes \\
\hline IND fixed effect & & No & No & Yes & No & No & No & Yes & No \\
\hline FIRM fixed effect & & No & Yes & No & Yes & No & Yes & No & Yes \\
\hline Sample Size & & 1067 & 1067 & 1067 & 1067 & 558 & 558 & 558 & 558 \\
\hline Adj. $\mathrm{R}^{2}$ & & 0.223 & 0.832 & 0.550 & 0.840 & 0.280 & 0.889 & 0.699 & 0.901 \\
\hline
\end{tabular}


DO CORPORATE GOVERNANCE ANALYSTS MATTER? EVIDENCE FROM A QUASI-NATURAL EXPERIMENT

Appendix 4 - 5: Detailed DiD Regression Analyses (w.r.t. Table 4 - 5) (continued)

Panel B. Prediction 2: Governance Analysts and Investors

\begin{tabular}{|c|c|c|c|c|c|c|c|c|c|}
\hline & \multirow{3}{*}{$\begin{array}{l}\text { Pred. } \\
\text { Sign }\end{array}$} & \multicolumn{8}{|c|}{ Dependent variable: Free Float } \\
\hline & & \multicolumn{4}{|c|}{ Treatment Group \& Control Group 1} & \multicolumn{4}{|c|}{ Treatment Group \& Control Group 2} \\
\hline & & Model 1 & Model 2 & Model 3 & Model 4 & Model 5 & Model 6 & Model 7 & Model 8 \\
\hline Intercept & & $\begin{array}{c}54.97 * * * \\
(45.61) \\
\end{array}$ & $\begin{array}{c}55.94 * * * \\
(55.11) \\
\end{array}$ & $\begin{array}{c}44.07 * * * \\
(5.02) \\
\end{array}$ & $\begin{array}{l}1.829 \\
(0.03) \\
\end{array}$ & $\begin{array}{c}61.66^{* * * *} \\
(42.19)\end{array}$ & $\begin{array}{c}59.66^{* * * *} \\
(119.72) \\
\end{array}$ & $\begin{array}{c}60.18^{* * * *} \\
(4.48)\end{array}$ & $\begin{array}{c}68.229 \\
(0.63) \\
\end{array}$ \\
\hline POST & & $\begin{array}{l}0.513 \\
(0.37)\end{array}$ & $\begin{array}{l}-2.218 \\
(-1.12)\end{array}$ & (omitted) & (omitted) & & & (omitted) & (omitted) \\
\hline ANTE & & & & & & $\begin{array}{l}-0.898 \\
(-0.48)\end{array}$ & $\begin{array}{l}-0.602 \\
(-0.26)\end{array}$ & & \\
\hline TREATED & & $\begin{array}{l}-0.877 \\
(-0.44) \\
\end{array}$ & (omitted) & $\begin{array}{r}-3.354 \\
(-1.45) \\
\end{array}$ & (omitted) & $\begin{array}{l}-2.882 \\
(-1.51) \\
\end{array}$ & (omitted) & $\begin{array}{l}0.496 \\
(0.22) \\
\end{array}$ & (omitted) \\
\hline POST_TREATED & + & $\begin{array}{c}4.176^{* *} \\
(1.98)\end{array}$ & $\begin{array}{c}6.555^{* *} \\
(2.18)\end{array}$ & $\begin{array}{c}4.775^{* *} \\
(2.22)\end{array}$ & $\begin{array}{l}5.297^{*} \\
(1.72)\end{array}$ & & & & \\
\hline ANTE_TREATED & - & & & & & $\begin{array}{l}-3.791 \\
(-1.54) \\
\end{array}$ & $\begin{array}{l}-3.735 \\
(-1.23) \\
\end{array}$ & $\begin{array}{l}-3.778 \\
(-1.48) \\
\end{array}$ & $\begin{array}{l}-3.245 \\
(-1.01) \\
\end{array}$ \\
\hline $\mathbf{A F}$ & & & & $\begin{array}{l}-0.195 \\
(-0.69)\end{array}$ & $\begin{array}{l}-0.482 \\
(-0.67)\end{array}$ & & & $\begin{array}{c}0.356^{*} \\
(1.70)\end{array}$ & $\begin{array}{l}0.311 \\
(0.81)\end{array}$ \\
\hline FTSE100 & & & & $\begin{array}{l}-0.923 \\
(-0.21)\end{array}$ & (omitted) & & & $\begin{array}{l}-1.867 \\
(-0.77)\end{array}$ & (omitted) \\
\hline ASSET4_COV & & & & $\begin{array}{l}3.103 \\
(1.30)\end{array}$ & (omitted) & & & $\begin{array}{l}0.971 \\
(0.46)\end{array}$ & $\begin{array}{l}-1.127 \\
(-0.19)\end{array}$ \\
\hline SIZE & & & & $\begin{array}{l}1.299^{*} \\
(1.88)\end{array}$ & $\begin{array}{l}4.742 \\
(0.90)\end{array}$ & & & $\begin{array}{l}0.297 \\
(0.31)\end{array}$ & $\begin{array}{l}-2.074 \\
(-0.25)\end{array}$ \\
\hline LEV & & & & $\begin{array}{l}-1.837 \\
(-0.45)\end{array}$ & $\begin{array}{l}1.940 \\
(0.29)\end{array}$ & & & $\begin{array}{l}-5.541 \\
(-1.34)\end{array}$ & $\begin{array}{l}-3.027 \\
(-0.46)\end{array}$ \\
\hline ROA & & & & $\begin{array}{c}-6.948 * * \\
(-2.58)\end{array}$ & $\begin{array}{l}-4.006 \\
(-0.45)\end{array}$ & & & $\begin{array}{l}-9.154 \\
(-1.42)\end{array}$ & $\begin{array}{l}-3.896 \\
(-0.34)\end{array}$ \\
\hline SD_STOCK & & & & $\begin{array}{l}6.007 \\
(0.66)\end{array}$ & $\begin{array}{l}3.619 \\
(0.21)\end{array}$ & & & $\begin{array}{c}-21.536 \\
(-1.63)\end{array}$ & $\begin{array}{l}6.837 \\
(0.30)\end{array}$ \\
\hline DPS & & & & $\begin{array}{c}0.550^{* * *} \\
(5.50) \\
\end{array}$ & $\begin{array}{l}0.289 \\
(0.17) \\
\end{array}$ & & & $\begin{array}{c}0.450^{* * *} \\
(4.54) \\
\end{array}$ & $\begin{array}{l}-0.756 \\
(-0.53) \\
\end{array}$ \\
\hline YEAR fixed effect & & No & No & Yes & Yes & No & No & Yes & Yes \\
\hline IND fixed effect & & No & No & Yes & No & No & No & Yes & No \\
\hline FIRM fixed effect & & No & Yes & No & Yes & No & Yes & No & Yes \\
\hline Sample Size & & 1067 & 1067 & 1067 & 1067 & 558 & 558 & 558 & 558 \\
\hline Adj. $\mathrm{R}^{2}$ & & 0.003 & 0.219 & 0.247 & 0.579 & 0.010 & -0.038 & 0.496 & 0.668 \\
\hline
\end{tabular}


DO CORPORATE GOVERNANCE ANALYSTS MATTER? EVIDENCE FROM A QUASI-NATURAL EXPERIMENT

Appendix 4 - 5: Detailed DiD Regression Analyses (w.r.t. Table 4 - 5) (continued)

Panel C. Prediction 3: Governance Analysts and Corporate Governance

\begin{tabular}{|c|c|c|c|c|c|c|c|c|c|}
\hline & \multirow{3}{*}{$\begin{array}{l}\text { Pred. } \\
\text { Sign }\end{array}$} & \multicolumn{8}{|c|}{ Dependent variable: Corporate Governance Quality (ASSET4) } \\
\hline & & \multicolumn{4}{|c|}{ Treatment Group \& Control Group 1} & \multicolumn{4}{|c|}{ Treatment Group \& Control Group 2} \\
\hline & & Model 1 & Model 2 & Model 3 & Model 4 & Model 5 & Model 6 & Model 7 & Model 8 \\
\hline Intercept & & & & & & $\begin{array}{c}70.31 * * * \\
(36.47) \\
\end{array}$ & $\begin{array}{c}63.99 * * * \\
(136.11) \\
\end{array}$ & $\begin{array}{c}-13.500 \\
(-0.46) \\
\end{array}$ & $\begin{array}{c}-157.905 \\
(-1.41) \\
\end{array}$ \\
\hline \multicolumn{10}{|l|}{ POST } \\
\hline ANTE & & & & & & $\begin{array}{c}4.814 * * \\
(2.17)\end{array}$ & $\begin{array}{l}4.118 \\
(1.61)\end{array}$ & (omitted) & (omitted) \\
\hline TREATED & & & & & & $\begin{array}{c}-11.442^{* * *} * \\
(-3.89) \\
\end{array}$ & (omitted) & $\begin{array}{l}-2.779 \\
(-0.81)\end{array}$ & (omitted) \\
\hline POST_TREATED & + & & & & & & & & \\
\hline ANTE_TREATED & - & & & & & $\begin{array}{c}-9.480 * * * \\
(-3.39)\end{array}$ & $\begin{array}{c}-7.506 * * \\
(-2.34) \\
\end{array}$ & $\begin{array}{c}-9.038 * * * \\
(-3.17)\end{array}$ & $\begin{array}{l}-5.950 * \\
(-1.82)\end{array}$ \\
\hline $\mathbf{A F}$ & & & & & & & & $\begin{array}{l}-0.477 \\
(-1.46)\end{array}$ & $\begin{array}{l}0.746 \\
(1.48)\end{array}$ \\
\hline FTSE100 & & & & & & & & $\begin{array}{l}0.475 \\
(0.11)\end{array}$ & (omitted) \\
\hline PF & & & & & & & & $\begin{array}{c}-0.284 * * * \\
(-2.79)\end{array}$ & $\begin{array}{l}-0.033 \\
(-0.35)\end{array}$ \\
\hline $\mathbf{Q}$ & & & & & & & & $\begin{array}{l}-0.015 \\
(-0.00)\end{array}$ & $\begin{array}{l}-3.407 \\
(-0.42)\end{array}$ \\
\hline OWNER & & & & & & & & $\begin{array}{l}-0.125 \\
(-1.46)\end{array}$ & $\begin{array}{l}-0.021 \\
(-0.20)\end{array}$ \\
\hline SIZE & & & & & & & & $\begin{array}{c}6.554 * * * \\
(3.22)\end{array}$ & $\begin{array}{c}15.859^{* *} \\
(1.97)\end{array}$ \\
\hline ROA & & & & & & & & $\begin{array}{l}12.983 \\
(1.26)\end{array}$ & $\begin{array}{l}14.110 \\
(1.39)\end{array}$ \\
\hline LEV & & & & & & & & $\begin{array}{c}-12.585 * * \\
(-1.96)\end{array}$ & $\begin{array}{c}-12.849 \\
(-1.52)\end{array}$ \\
\hline GROWTH & & & & & & & & $\begin{array}{l}-3.237 \\
(-0.83) \\
\end{array}$ & $\begin{array}{l}-5.551 \\
(-1.33)\end{array}$ \\
\hline YEAR fixed effect & & & & & & No & No & Yes & Yes \\
\hline IND fixed effect & & & & & & No & No & Yes & No \\
\hline FIRM fixed effect & & & & & & No & Yes & No & Yes \\
\hline Sample Size & & & & & & 305 & 305 & 305 & 305 \\
\hline Adj. $R^{2}$ & & & & & & 0.150 & 0.667 & 0.279 & 0.694 \\
\hline
\end{tabular}




\section{Appendix 4 - 5: Detailed DiD Regression Analyses (w.r.t. Table 4 - 5) (continued)}

Panel D. Prediction 4: Governance Analysts and Earnings Management

\begin{tabular}{|c|c|c|c|c|c|c|c|c|c|}
\hline & \multirow{3}{*}{$\begin{array}{l}\text { Pred. } \\
\text { Sign }\end{array}$} & \multicolumn{8}{|c|}{ Dependent variable: Absolute Discretionary Accruals } \\
\hline & & \multicolumn{4}{|c|}{ Treatment Group \& Control Group 1} & \multicolumn{4}{|c|}{ Treatment Group \& Control Group 2} \\
\hline & & Model 1 & Model 2 & Model 3 & Model 4 & Model 5 & Model 6 & Model 7 & Model 8 \\
\hline Intercept & & $\begin{array}{c}0.06^{* * * *} \\
(13.33)\end{array}$ & $\begin{array}{c}0.07 * * * \\
(15.12)\end{array}$ & $\begin{array}{c}0.17 * * * \\
(4.62)\end{array}$ & $\begin{array}{c}0.53 * \\
(1.69)\end{array}$ & $\begin{array}{c}0.05^{* * * *} \\
(12.18)\end{array}$ & $\begin{array}{c}0.05 * * * \\
(26.74)\end{array}$ & $\begin{array}{c}0.19^{* * *} \\
(4.62)\end{array}$ & $\begin{array}{l}-0.060 \\
(-0.16)\end{array}$ \\
\hline POST & & $\begin{array}{c}0.028 * * * \\
(4.36)\end{array}$ & $\begin{array}{c}0.020 * * \\
(2.02)\end{array}$ & (omitted) & (omitted) & & & (omitted) & (omitted) \\
\hline ANTE & & & & & & $\begin{array}{l}0.015^{*} \\
(1.90)\end{array}$ & $\begin{array}{c}0.017 * \\
(1.78)\end{array}$ & & \\
\hline TREATED & & $\begin{array}{l}0.003 \\
(0.47) \\
\end{array}$ & (omitted) & $\begin{array}{c}0.023 * * * \\
(2.84) \\
\end{array}$ & (omitted) & $\begin{array}{l}0.004 \\
(0.70) \\
\end{array}$ & (omitted) & $\begin{array}{l}-0.012 \\
(-1.56) \\
\end{array}$ & (omitted) \\
\hline POST_TREATED & - & $\begin{array}{c}-0.043 * * * \\
(-4.68)\end{array}$ & $\begin{array}{c}-0.034 * * \\
(-2.53)\end{array}$ & $\begin{array}{c}-0.036 * * * \\
(-3.83)\end{array}$ & $\begin{array}{c}-0.034^{* * *} \\
(-2.61)\end{array}$ & & & & \\
\hline ANTE_TREATED & + & & & & & $\begin{array}{l}-\mathbf{- 0 . 0 0 1} \\
\mathbf{( - 0 . 0 5 )} \\
\end{array}$ & $\begin{array}{l}-0.003 \\
(-0.26) \\
\end{array}$ & $\begin{array}{l}\mathbf{0 . 0 0 1} \\
(0.09) \\
\end{array}$ & $\begin{array}{l}0.002 \\
(0.15) \\
\end{array}$ \\
\hline $\mathbf{A F}$ & & & & $\begin{array}{l}0.001 \\
(0.90)\end{array}$ & $\begin{array}{l}-0.001 \\
(-0.46)\end{array}$ & & & $\begin{array}{l}-0.000 \\
(-0.24)\end{array}$ & $\begin{array}{l}0.000 \\
(0.08)\end{array}$ \\
\hline LOSS & & & & $\begin{array}{c}0.016^{* *} \\
(2.07)\end{array}$ & $\begin{array}{l}0.017 \\
(1.26)\end{array}$ & & & $\begin{array}{c}0.022 * * \\
(2.49)\end{array}$ & $\begin{array}{l}0.020 \\
(1.33)\end{array}$ \\
\hline FTSE100 & & & & $\begin{array}{l}-0.010 \\
(-0.68)\end{array}$ & (omitted) & & & $\begin{array}{l}0.005 \\
(0.56)\end{array}$ & (omitted) \\
\hline ASSET4_COV & & & & $\begin{array}{l}0.000 \\
(0.06)\end{array}$ & (omitted) & & & $\begin{array}{l}-0.004 \\
(-0.66)\end{array}$ & $\begin{array}{l}-0.012 \\
(-0.60)\end{array}$ \\
\hline PF & & & & $\begin{array}{l}-0.000 \\
(-0.03)\end{array}$ & $\begin{array}{l}0.000 \\
(0.03)\end{array}$ & & & $\begin{array}{c}-0.001 * * * \\
(-2.73)\end{array}$ & $\begin{array}{c}-0.001 * * \\
(-2.27)\end{array}$ \\
\hline OWNER & & & & $\begin{array}{l}0.000 \\
(0.34)\end{array}$ & $\begin{array}{l}0.000 \\
(0.28)\end{array}$ & & & $\begin{array}{l}0.000 \\
(0.70)\end{array}$ & $\begin{array}{l}-0.000 \\
(-0.69)\end{array}$ \\
\hline SIZE & & & & $\begin{array}{c}-0.009 * * * \\
(-2.90)\end{array}$ & $\begin{array}{l}-0.043 \\
(-1.52)\end{array}$ & & & $\begin{array}{c}-0.008^{* *} \\
(-2.48)\end{array}$ & $\begin{array}{l}0.009 \\
(0.34)\end{array}$ \\
\hline LEV & & & & $\begin{array}{c}0.052 * * \\
(2.13)\end{array}$ & $\begin{array}{l}0.058 \\
(0.82)\end{array}$ & & & $\begin{array}{l}0.014 \\
(0.66)\end{array}$ & $\begin{array}{l}0.004 \\
(0.07)\end{array}$ \\
\hline CFO & & & & $\begin{array}{c}-0.069 * * \\
(-2.41)\end{array}$ & $\begin{array}{l}-0.027 \\
(-0.36)\end{array}$ & & & $\begin{array}{l}0.025 \\
(0.69)\end{array}$ & $\begin{array}{l}-0.009 \\
(-0.08)\end{array}$ \\
\hline YEAR fixed effect & & No & No & Yes & Yes & No & No & Yes & Yes \\
\hline IND fixed effect & & No & No & Yes & No & No & No & Yes & No \\
\hline FIRM fixed effect & & No & Yes & No & Yes & No & Yes & No & Yes \\
\hline Sample Size & & 1067 & 1067 & 1067 & 1067 & 558 & 558 & 558 & 558 \\
\hline Adj. $\mathrm{R}^{2}$ & & 0.035 & 0.393 & 0.118 & 0.408 & 0.010 & 0.185 & 0.072 & 0.180 \\
\hline
\end{tabular}

Notes: The underlying basic regression model is:

$$
\begin{gathered}
\text { VI }_{\text {it }}=\alpha+\gamma_{1} \text { TREATED }_{\text {it }}+\gamma_{2} \text { POST } \times \text { TREATED }_{\text {it }}\left[\gamma_{2} \text { ANTE } \times \text { TREATED }_{i t}\right]+\sum \gamma_{2} \text { FIRM_CONTROL }_{\text {it }} \\
+\sum \gamma_{3} \text { YEAR }_{i t}+\sum \gamma_{4} \text { INDUSTRY }_{i t}+\varepsilon
\end{gathered}
$$

TREATED is a dummy variable indicating the treatment group. Depending on the underlying control group, the coefficient estimates on the variables POST $\times$ TREATED and ANTE $\times$ TREATED capture the DiD effect (for definitions of treatment and control group, see Table 4 - 1). Firm controls for analyst following (AF) regression (Panel A) are: blue chip index membership (FTSE100), alternative CG information (asset4 coverage), capital intensity (PPE to total assets), volatility of business (StD of cash from operations), stock price volatility (StD of monthly stock returns), brokerage commission (inverse stock price), accounting performance (ROA), growth (book-to-market ratio), institutional investors (pension funds holdings), ownership concentration (closely held shares), size (log of total assets), and leverage (total debt to total assets). Firm controls for free float (FF) regression (Panel B) are: blue chip index membership (FTSE100), alternative CG information (asset4 coverage), stock price volatility (StD of monthly stock returns), accounting performance (ROA), size (log of total assets), leverage (total debt to total assets), analyst following, and dividends per share. Firm controls for governance (GOV) regression (Panel C) are: size (log of total assets), growth (one-year change in net sales), accounting performance (ROA), blue chip index membership (FTSE100), firm valuation (Tobin's Q), analyst following, institutional investments (pension funds holdings), ownership concentration (closely held shares), and leverage (total debt to total assets). Firm controls for absolute Discretionary Accruals (ADAC) regression (Panel D) are: size (log of total assets), blue chip index membership (FTSE100), analyst following, institutional investments (pension funds holdings), ownership concentration (closely held shares), loss reporting, cash from operations, and leverage (total debt to total assets). For variable definition, see Appendix 4 - 1. In each Panel, Model 5 and 6 simulate the exogenous shock based on a sample without the treatment group but including both control groups. In these models, SPILLOVER is identical to POST $\times$ TREATED in terms of construction (with Control Group 2 as the simulated treatment group and Control Group 1 as the simulated control group). The coefficient estimate on SPILLOVER captures any spillover effects on the second original control group due to the exogenous shock in the original treatment group. The regression models contain industry- and year-fixed effects, and have robust standard errors which are one-way clustered at firm level. Alternatively to industry-fixed effects and the 
inclusion of TREATED, I additionally estimate the regression with firm-fixed effects (as indicated in Table 4 5). Reported values: coefficient (t-value) ${ }^{* * *}(* *)(*)$ indicates significance levels at $1 \%(5 \%)(10 \%)$, two-tailed. 


\title{
5. THE ROLE OF CORPORATE GOVERNANCE IN SHAPING ACCRUALS MANIPULATION PRIOR TO ACQUISITIONS
}

\author{
Nico Lehmann ${ }^{101}$ \\ Working Paper ${ }^{102}$, Georg-August-Universität Göttingen
}

\begin{abstract}
Based on stock swap transactions with public acquirers originating from the UK between the years 1998 and 2011, this paper investigates the role of corporate governance in shaping accruals manipulation prior to stock swap deals. In contrast to common claims that strong corporate governance constrains accruals manipulation, our results show that well governed acquirers engage more aggressively in income-increasing accruals manipulation than those with weak governance. This finding is consistent with a role of corporate governance which incentivizes managerial actions in the interests of firms' shareholders. Overall, this finding highlights the setting-specific nature of the earnings management and corporate governance relationship. Our results are robust to different discretionary accrual models, to differences in the firm's growth structure, to M\&A control variables, to a control group of $100 \%$ cash acquirers, to an analysis of buy-and-hold abnormal returns, and to potential sample selection problems.
\end{abstract}

JEL Classification: G34, M41

Keywords: Accrual-based earnings management, corporate governance, stock swap M\&A transactions

Acknowledgments: For valuable comments, I am grateful to Jörg-Markus Hitz (dissertation adviser), Daniel W. Collins, Joachim Gassen, Wayne Landsman, Catherine Shakespeare, and participants at the $3^{\text {rd }}$ WHU Doctoral Summer Program in Accounting Research, WHU Otto Beisheim School of Management in Vallendar, Germany (July 2012), the Research Seminar in Finance, Accounting, and Taxes, Goettingen University (January 2013), the EAA Doctoral Colloquium in Accounting in Saclay, France (May 2013), the Annual Meeting of the European Accounting Association in Paris, France (May 2013), the Annual Meeting of the American Accounting Association in Anaheim, USA (August 2013), and two anonymous reviewers. I also thank Paul Wanner and Kristof Ho Tiu (both, ISS Governance Services, formerly RiskMetrics Group) for providing the CGQ data.

\footnotetext{
${ }^{101}$ Georg-August-Universität Göttingen, Faculty of Economic Sciences, Chair of Accounting and Auditing, Platz der Göttinger Sieben 3, 37073 Göttingen, Germany.

102 The working paper is currently in a review process with Accounting and Business Research ('revise \& resubmit' in March 2014). As submitted to ABR, this paper is written in "we form". First version of the working paper: November 2012. This version: July 2014.
} 


\subsection{Introduction}

This paper investigates the role of corporate governance in shaping accrual-based earnings management prior to acquisitions. In doing so, we address and extend two related literature streams, the stream on earnings management prior to M\&A transactions (e.g., Erickson and Wang, 1999), and the stream on earnings management and corporate governance (e.g., Klein, 2002). Prior research predicts and finds evidence that acquiring firms manage earnings upward prior to share-based M\&A transactions (Erickson and Wang, 1999; Louis, 2004; Botsari and Meeks, 2008). Two recent studies, however, argue that these results are potentially biased due to the absence of growth adjustments in the estimation process of discretionary accruals (Pungaliya and Vijh, 2009; Collins et al., 2012). While the average effect of earnings management prior to stock swap deals as well as the sensitivity of the applied accrual measures have been addressed, so far only little attention has been paid to potential determinants of accruals manipulation in this specific setting (e.g., Young 2008, p. $673)$.

Although prior accounting research assumes a constraining role of corporate governance on accruals manipulation (e.g., Dechow et al., 1996), empirical evidence so far is rather mixed (e.g., Brown et al., 2011; Dechow et al., 2010; Larcker et al., 2007). We propose three non-exclusive explanations for this inconclusive evidence. First, prior evidence, which is based on settings that are unspecific to managerial incentives to manipulate accruals, might be affected by multiple and potentially conflicting earnings management motivations. Consequently, such evidence might be prone to a simultaneous aggregation of different types of earnings management, e.g., income-increasing, income-decreasing, or income-smoothing accruals manipulation. Second, accrual-based earnings management might not always be a signal of managerial opportunism contrasting the interests of firms' shareholders. In situations, for example, where managers manipulate accruals to avoid recontracting costs (Christi and Zimmerman, 1994) or to convey private information to the market (Healy and Wahlen, 1999), firms' shareholders might benefit from accruals manipulation. Third, conditional on the aforementioned point, corporate governance might affect earnings management in different ways.

To combine both streams of literature and to address the above stated points, we examine whether the acquirer's corporate governance quality affects the acquirer's earnings management behavior prior to share-based M\&A transactions. Our approach exploits a 
specific setting in which prior literature documents income-increasing accruals manipulation. More importantly, as accruals manipulation prior to share deals is potentially in the interests of the acquirer's invested shareholders, this setting offers an alternative perspective on the relationship between governance and earnings management. In line with the classical Principal-Agent-Theory (Jensen and Meckling, 1976), which suggests that corporate governance serves primarily the interests of firms' shareholders, good governance is expected to negotiate the lowest target price for the acquirer's shareholders, and hence promotes income-increasing accruals manipulation prior to the deal negotiation. Specifically, shareholders of the acquiring firm prefer lower target prices to minimize any dilution effects due to the stock swap component of the deal structure.

Using stock swap transactions with public acquirers originating from the UK between the years 1998 and 2011, our results confirm recent findings of Botsari and Meeks (2008) that acquirers on average manipulate accruals upward in the period leading up to the transactions. However, and contrary to common claims that strong corporate governance constrains accruals manipulation, our analyses of the period specific earnings management behavior prior to share deals suggest that acquirers with strong governance engage more aggressively in income-increasing accruals manipulation than those with weak governance. This finding is consistent with the role of corporate governance which incentivizes managerial actions in the interests of firms' shareholders. It is further robust to different discretionary accrual models, to differences in the firm's growth structure, to M\&A control variables, and to a control group of $100 \%$ cash acquirers. In addition, analyses of acquirers' long-term buy-and-hold abnormal returns (BHAR) surrounding the deal announcement support our findings. Specifically, they suggest that acquirers potentially succeed in inflating their stocks' purchasing power prior to the deal announcement and that - consistent with the predicted role of corporate governance well governed acquirers with more pronounced accruals manipulation are potentially more successful in inflating stock prices to reduce the costs of buying the target.

This paper makes several contributions to the literature. First, this is to our knowledge the first paper to shed light on the relationship between corporate governance and earnings management in a setting in which prior literature documents income-increasing accruals manipulation. Thus, it adds to research on earnings management and governance by controlling for potentially conflicting earnings management incentives as well as conflicting objectives, like income-smoothing, income-increasing, or income-decreasing accruals manipulation. More importantly, this paper exploits a specific setting in which we expect to 
find a promoting role of corporate governance on earnings management. To that end, it is the first paper that highlights the setting-specific nature of the earnings management and corporate governance relationship. Second, this paper extends research on accrual-based earnings management prior to M\&A transactions by considering the acquirer's governance quality, different firm and M\&A related characteristics, and by controlling for differences in firm's growth structures via growth adjustments in the estimation process of discretionary accruals.

Our findings are important for investors and other users of financial reporting. For one reason, they shed light on the endogenous nature of earnings quality, i.e., accrual-based earnings management, as well as on the role of corporate governance with its respective beneficial or detrimental outcomes for current as well as potential shareholders and other stakeholders. Specifically, in situations, like stock swap M\&A transactions, our results are consistent with the notion that corporate governance potentially promotes accruals manipulation in the interests of firms' current investors but at the expense of future (target) investors.

The remainder of the paper is as follows. Section 5.2 provides a brief review of related literature. Section 5.3 discusses the hypothesis development. Section 5.4 gives an overview of the research design. Section 5.5 presents the results and discusses the implications of the main findings. The last section concludes.

\subsection{Prior Literature}

This paper speaks basically to two related streams of literature, the governance and accrualbased earnings management literature, as well as the accrual-based earnings management and M\&A literature. Table 5 - 1 presents an overview.

\section{Corporate Governance and Earnings Management}

Based on U.S. firms for the years 1992 and 1993, Klein (2002) finds evidence that internal governance structures (e.g., audit committee and board independence) constrain accruals manipulation. Davidson et al. (2005) partly support these findings. They find evidence for Australian firms that some internal governance structures (e.g., board and audit committee independence) reduce the extent of accruals manipulation, whereas others (like auditor choice 
and the firm's voluntary establishment of an internal audit function) do not. Larcker et al. (2007) examine the relationship between various governance measures and different accounting and financial outcomes in a U.S. setting. Overall, they find mixed evidence of a link between governance quality and abnormal accruals, little evidence of a relation between governance and accounting restatements, and some evidence of a positive effect of governance quality on future operating performance. They argue that the mixed results are partly due to the lack of consistent and reliable measures of broad corporate governance structures. A recent study for Europe was conducted by Renders and Vandenbogaerde (2008). For a sample period between 1999 and 2003, they find a negative relationship between different governance mechanisms (e.g., shareholder rights, anti-takeover provisions, and board characteristics) and income-increasing accruals manipulation. Moreover, they indicate that firm-level governance constrains more effectively the use of discretionary accruals in countries with higher quality (country-level) governance standards and they show that their results are mainly driven by code law countries. To our knowledge, only Cormier and Martinez (2006) consider governance-related structures and earnings management in a specific setting. They find evidence for French IPO firms that managers' leeway to manipulate accruals in order to reduce their earnings forecast errors in the post IPO period is limited by audit quality and ownership concentration. However, they do not find similar evidence for board independence or compliance with IFRS.

Overall, the majority of prior studies examines the relationship between single governance mechanisms and accruals manipulation and finds some evidence for board characteristics and weak or even mixed evidence for further internal governance mechanisms (for a comprehensive overview, see Garcia-Meca and Sanchez-Ballesta 2009, pp. 600-601). However, as to our knowledge, none of the previous studies examines the link between firmlevel corporate governance mechanisms and accruals manipulation in a setting - like stock swap M\&A transactions - in which specific incentives to manipulate earnings upward are expected to be dominant.

\section{Earnings Management prior to share-based M\&A Transactions}

Based on a U.S. sample of 55 stock swap transactions between the years 1985 and 1990, Erickson and Wang (1999) examine whether acquiring firms manage earnings upward prior to M\&A transactions. Their results suggest that acquirers in such transactions engage in income- 
increasing accruals manipulation to reduce the purchase costs of the target firms. Consistent with that, Louis (2004) finds evidence for 236 U.S. transactions between the years 1992 and 2000 that acquirers manipulate quarterly earnings via discretionary accruals prior to the stock swap announcement. Botsari and Meeks (2008) provide the first non-U.S. evidence. They examine the acquirer's discretionary accruals for $48 \mathrm{UK}$ share-based M\&A transactions for the period between 1997 and 2001. Consistent with the findings of Erickson and Wang (1999) and Louis (2004), they show that acquiring firms engage in accruals manipulation in the periods (one and two years) prior to the announcement of the transactions.

Table 5 - 1: Prior Literature on Corporate Governance and Earnings Management

Panel A. Corporate Governance and accrual-based Earnings Management

\begin{tabular}{|c|c|c|}
\hline Authors & Sample & Main Findings \\
\hline Davidson et al. (2005) & $\begin{array}{l}\text { - } 434 \text { Australian firms } \\
\text { - For the year } 2000\end{array}$ & $\begin{array}{l}\text { - Internal CG (majority of NED on board \& audit } \\
\text { committee) reduces accrual-based EM (no effect for } \\
\text { auditor choice) }\end{array}$ \\
\hline Klein (2002) & $\begin{array}{l}\text { - U.S. sample with } 692 \\
\text { firm-years ('92-'93) }\end{array}$ & $\begin{array}{l}\text { - Internal CG (audit committee and board independence) } \\
\text { reduces the extent of accrual-based EM }\end{array}$ \\
\hline Larcker et al. (2007) & $\begin{array}{l}\text { - U.S. sample with } \\
\text { 2,106 firms (for the } \\
\text { year 2003) }\end{array}$ & $\begin{array}{l}\text { - Mixed evidence of a link between accrual-based EM } \\
\text { and CG (aggregated measure of } 14 \text { CG dimensions) }\end{array}$ \\
\hline $\begin{array}{l}\text { Renders and Vanden- } \\
\text { bogaerde }(2008)\end{array}$ & $\begin{array}{l}\text { - European firms with } \\
655 \text { firm-year obs. } \\
\text { (from '99-'03) }\end{array}$ & $\begin{array}{l}\text { - Negative link between accrual-based EM and CG } \\
\text { quality (firm-level CG and institutional characteristics } \\
\text { appear to be complementary) }\end{array}$ \\
\hline $\begin{array}{l}\text { Cormier and Martinez } \\
(2006)\end{array}$ & $\begin{array}{l}\text { - } 118 \text { French IPO firms } \\
\text { (from 2000-2002) }\end{array}$ & $\begin{array}{l}\text { - Negative link between accrual-based EM and CG } \\
\text { (audit quality, ownership concentration) in post IPO } \\
\text { period (no evidence of board independence) }\end{array}$ \\
\hline
\end{tabular}

Panel B. Accrual-based Earnings Management prior to share-based M\&A Transactions

\begin{tabular}{|c|c|c|}
\hline Authors & Sample & Main Findings \\
\hline $\begin{array}{l}\text { Erickson and Wang } \\
\text { (1999) }\end{array}$ & $\begin{array}{l}\text { - } 55 \text { U.S. transactions } \\
\text { (from 1985-1990) }\end{array}$ & $\begin{array}{l}\text { - Evidence of accrual-based EM prior to share-based } \\
\text { M\&A (based on quarterly data) }\end{array}$ \\
\hline Heron and Lie (2002) & $\begin{array}{l}\text { - } 427 \text { U.S. transactions } \\
\text { (from 1985-1997) }\end{array}$ & $\begin{array}{l}\text { - No evidence of accrual-based EM prior to share-based } \\
\text { mergers (based on yearly data) }\end{array}$ \\
\hline Louis (2004) & $\begin{array}{l}\text { - } 236 \text { U.S. transactions } \\
\text { (from 1992-2000) }\end{array}$ & $\begin{array}{l}\text { - Evidence of accrual-based EM prior to share-based } \\
\text { transactions (based on quarterly data) }\end{array}$ \\
\hline Baik et al. (2007) & $\begin{array}{l}\text { - } 1,507 \text { U.S. mergers } \\
\text { (from 1990-1998) }\end{array}$ & $\begin{array}{l}\text { Evidence that higher pricing uncertainty for acquirer } \\
\text { (measured by target public status, target size, industrial } \\
\text { relatedness) promotes accruals manipulation }\end{array}$ \\
\hline $\begin{array}{l}\text { Botsari and Meeks } \\
(2008)\end{array}$ & $\begin{array}{l}\text { - } 48 \text { UK transactions } \\
\text { (from 1997-2001) }\end{array}$ & $\begin{array}{l}\text { - Support the findings of Erickson and Wang (1999) and } \\
\text { Louis (2004), but with yearly UK data }\end{array}$ \\
\hline $\begin{array}{l}\text { Pungaliya and Vijh } \\
\text { (2009) }\end{array}$ & $\begin{array}{l}\text { - } 895 \text { U.S. transactions } \\
\text { (from 1989-2005) }\end{array}$ & $\begin{array}{l}\text { - No evidence of EM prior to share-based M\&A } \\
\text { They control for growth differences in the estimation } \\
\text { process of discretionary accruals }\end{array}$ \\
\hline
\end{tabular}


In contrast, Heron and Lie (2002) examine acquirers' discretionary accruals for 859 U.S. transactions (including 427 share deals) in a period between 1985 and 1997 and do not find evidence supporting accruals manipulation prior to share-based deals. Moreover, two recent studies present opposing results as well and argue that prior findings are potentially biased due to the absence of growth adjustments in the estimation process of discretionary accruals (Pungaliya and Vijh, 2009; Collins et al., 2012). Collins et al. (2012) point out that when using standard Jones-type discretionary accrual models it is likely to overestimate the likelihood of accruals manipulation in quarterly settings where firms with high or low growth characteristics are overrepresented.

Although prior literature scrutinizes the average effect of accruals manipulation prior to share deals, so far potential determinants of accruals manipulation in this setting remain largely unresearched (e.g., Young, 2008, p. 673). As to our knowledge, only Baik et al. (2007) address explicitly determinants of earnings management in a setting of M\&A transactions. ${ }^{103}$ They predict that the acquirer's pricing uncertainty promotes accruals manipulation prior to share deals. Using target public status, target size, and industrial relatedness between acquirer and target as proxies for acquirer's pricing uncertainty, they find evidence in support of their prediction.

\subsection{Hypothesis Development}

\section{Earnings management prior to $M \& A$ transactions}

While empirical evidence suggests that managers engage in income-increasing accruals manipulation prior to share-based M\&A transactions, academic literature remains surprisingly silent on the manager's actual incentive to do so and the potential determinants that shape earnings management prior to such deals (Young, 2008; Baik et al., 2007). On a more general level, Erickson and Wang (1999) and Botsari and Meeks (2008) argue that managers of acquiring firms try to minimize the target price by income-increasing earnings manipulation. In share-based deals, the exchange ratio of the transactions - the amount of shares of the acquiring firm designated for one share of the target firm - plays an important role and allocates the wealth of the respective shareholders. Accruals manipulation prior to stock swap deals is thus consistent with the notion that managers of acquiring firms manage earnings

${ }^{103}$ In addition, Erickson and Wang (1999) examine whether the deal ratio and ownership serve as additional economic incentives to engage in earnings management prior to share deals. Moreover, Pungaliya and Vijh (2009) examine whether acquirers strategically time their deal announcements. 
upward prior to share deals in order to temporarily inflate their share prices, and thus to decrease their exchange ratios as well as the target prices (Erickson and Wang, 1999, Heron and Lie, 2002). ${ }^{104}$

\section{Corporate governance and earnings management}

In the context of this paper, the term corporate governance denotes firm-level control and incentive mechanisms which address agency costs within a firm. ${ }^{105}$ Based on the classical Principal-Agent-Theory (Jensen and Meckling, 1976), agency costs result from interest divergences and information asymmetries between shareholders (principal) and management (agent) in firms with separated ownership and control. ${ }^{106}$ Following this shareholder value perspective, the core task of corporate governance is to overcome the agency conflict and thus to serve the interests of the shareholders (principal). ${ }^{107}$ Prior research on corporate governance has focused on various governance mechanisms such as shareholder rights, the structure and the composition of boards (and board committees), executive compensation contracts, block holders, institutional investors, disclosure, transparency, or the financial reporting system (e.g., Bebchuk and Weisbach, 2010; Becht et al., 2005; for an overview, see Schillhofer, 2003, pp. 25-59).

Among the various governance mechanisms, the financial reporting process in general, and the accounting quality in particular, constitutes a specific governance mechanism. The quality of the financial reporting process can be seen both as an input as well as an output factor of the governance process (e.g., Sloan, 2001). High quality financial reporting, for example, promotes the governance process by reducing information asymmetries between the

\footnotetext{
${ }^{104}$ Erickson and Wang (1999, p. 154) acknowledge disincentives for earnings management as well. Since target firms and their M\&A consultancies (e.g., investment banks) appear to be sophisticated financial statement users there is a potential threat that earnings management might be detected. It remains, however, difficult to fully disentangle the effects of accounting discretion since earnings management occurs within the boundaries of accounting principles.

${ }^{105}$ Following Jensen and Meckling (1976), agency costs are divided into three components: residual costs, monitoring costs, and bonding costs. Monitoring costs are essentially control and incentive expenditures borne by the principal. Bonding costs serve as signaling costs occurring when the agent signals his or her stewardship qualities. Given optimal monitoring and bonding, the residual costs occur as a (residual) loss in welfare because interest divergence between both parties will lead at best to a second-best optimum.

${ }^{106}$ Ideally, both contracting parties could negotiate a complete contract settling all tasks and duties of the agent, e.g., the allocation of profits, to solve the agency conflict (e.g., Hart, 1995). Since real world contracts are incomplete, e.g., owing to transaction costs, the principal has to delegate residual control rights to the agent (Shleifer and Vishny, 1997). In addition, in firms where ownership and control are separated, the principal is not able to fully oversee the actions of the agent, e.g., the agent's discretionary allocation of the firm's profit, due to information asymmetries.

${ }^{107}$ Besides this traditional, Anglo-Saxon 'shareholder value' perspective, the agency relationship might differ across jurisdictions depending on the respective institutional arrangements (e.g., Schillhofer, 2003, p. 7; or more generally with respect to the 'stakeholder value' perspective, see, Schmidt and Weiß, 2003, pp. 115-118).
} 
principals and the agents. In addition, corporate governance in turn is expected to increase the integrity and the reliability of the financial reporting process by implementing control and incentive mechanisms to mitigate opportunistic behavior. Specifically, corporate governance is expected to improve the financial reporting quality by constraining, among other things, earnings management (Dechow et al., 1996, p. 4). Earnings management can be described as the managers' opportunistic use of accounting discretion in the financial reporting process. Managers may have incentives to alter reporting outcomes to mislead stakeholders about the firms' underlying performance or to influence contractual outcomes (Healy and Wahlen, 1999). Since earnings management activities potentially contrast the interests of the principal, e.g., in situations where the profit allocation between the principal and the agent is influenced by earnings manipulations, earnings management induces agency costs. As governance mechanisms are designed to alleviate agency costs within a firm, they are also expected to constrain the opportunistic use of accounting discretion.

\section{Corporate governance and earnings management prior to $M \& A$ transactions}

In settings where managers engage in earnings management to increase managerial wealth at the expense of the firm's shareholders, e.g., in fraud settings (Farber, 2005), corporate governance is expected to constrain managerial opportunism. In those settings, high accounting quality, e.g., in terms of low discretionary accruals, serves the interests of shareholders by mitigating information asymmetries, and agency costs. However, in situations where managers manipulate earnings in the interests of the firm's shareholders, the role of corporate governance might differ. Christie and Zimmerman (1994, p. 542), for example, note that in situations of financial distress income-increasing accruals manipulation might "increase firm value by reducing recontracting costs with debtholders". Thus, earnings management is not per se a signal of managerial opportunism opposing the interests of the firm's shareholders.

Likewise, in stock swap M\&A transactions, it is plausible to assume that the shareholders of the acquiring firm potentially benefit from income-increasing accruals manipulation prior to the deal negotiation (Dechow et al., 1996; Erickson and Wang, 1999; Young, 2008). In particular, Erickson and Wang (1999, p. 150) suggest that managers' incentives to manipulate earnings prior to share-based M\&A transactions are stimulated by the preferences of existing shareholders. Existing or current shareholders of the acquiring firms prefer lower target prices in order to minimize any earnings and control right dilutions 
due to the stock swap component of the deal structure. In the absence of managerial opportunism, accruals manipulation prior to stock swap deals might be driven by an agency conflict between current and future shareholders rather than between managers and shareholders. ${ }^{108}$ Thus, consistent with the classical agency theory, one might expect that strong corporate governance negotiates the best acquisition price - the most favorable exchange ratio - for the shareholders of the acquiring firm. Put differently, it is plausible to assume that strong corporate governance promotes income-increasing earnings management prior to stock swap deals. ${ }^{109}$ Therefore, we state our hypothesis as follows:

H1: Well governed acquirers engage more strongly in income-increasing earnings management prior to share-based M\&A transactions compared to poorly governed acquirers.

\subsection{Research Design}

\subsubsection{Sample Selection}

The sample consists of stock swap M\&A transactions with acquirers originating from the UK between the years 1998 to 2011 . We analyze the UK market due to the following reasons. We directly build on a recent earnings management study conducted by Botsari and Meeks (2008) and extend their UK findings in sample size, growth adjustment in the estimation process of discretionary accruals, and analysis of determinants of accruals manipulation preceding the stock swap transactions. Moreover, we focus on the UK setting because it offers the most vital non-U.S. M\&A market (Botsari and Meeks, 2008, p. 633) and provides a single country setting with sufficient transactions for statistical analyses.

The M\&A sample is drawn from the database SDC Platinum after applying the following selection criteria: (1) the announcement date of the transaction falls in the period

\footnotetext{
${ }^{108}$ Consistent with that, prior studies on financial analysts suggest that - compared to internal governance mechanisms - external monitors (like financial analysts or high quality auditors) are superior in constraining earnings management in situations where agency conflicts between current and future shareholders prevail (Yu, 2008; Bolton et al., 2005). Yu (2008, p. 248), for example, argues that "current shareholders could choose to incentivize management for short-term stock performance, even with the understanding that this creates incentives for management to manipulate earnings".

109 Given the overvaluation or rational expectation theory as an alternative explanation for increasing discretionary accruals prior to stock swap transactions, the role of governance in promoting earnings management is unlikely to change. Following the overvaluation or rational market expectation theory, market participants potentially expect the stock swap acquirer's equity to be overvalued at the announcement of the stock financed deal and thus discount the acquirer's stock prices at the announcement date regardless of any specific earnings management indications (Shivakumar, 2000, pp. 339-344; Heron and Lie, 2002, p. 137; Louis, 2004, p. 122; Erickson and Wang, 1999, pp. 154). Consequently, acquiring firms potentially manipulate accruals prior to share deals in order to mask the equity's overvaluation as well as to respond rationally to the anticipated market reaction. Since these earnings manipulations are not contrasting the interest of current shareholders, we do not expect that internal governance mechanisms constrain such use of accounting discretion.
} 
between $01 / 01 / 1998$ and $31 / 12 / 2011$, (2) the acquirer's domicile country is the United Kingdom, (3) the acquirer is a public firm, (4) the target is a public firm ${ }^{110}$, (5) the acquisition technique is stock swap (either pure stock swap or mixed with explicitly identifiable share element, SDC code 32; see Botsari and Meeks, 2008, p. 640), (6) the acquirer is a nonfinancial firm (SIC codes 60 to 69 are excluded), (7) in cases of multiple stock swap transactions per firm, the first transaction remains in the sample to avoid overlapping data ${ }^{11}$ (Botsari and Meeks, 2008, p. 640), (8) all relevant data is available in SDC and Datastream / Worldscope, and (9) governance data is available for the acquirer. As a result of these selection criteria, the final sample consists of 70 deals. Table 5 - 2 gives an overview of the sample selection and the sample distribution.

Table 5 - 2: Sample Selection

Panel A. SDC Platinum - International Mergers (IMA): Start Parameter

- $\quad$ Date announced: 01/01/1998 to 31/12/2011

- Acquirer Nation: UK

- Acquirer Public Status: P (public)

- Target Public Status: P (public)

- Acquisition Technique: 32 (stock swap)

Panel B. Sample Selection

\begin{tabular}{lcc}
\hline Initial Sample (with ISIN available) & 352 \\
Financial acquirer & -106 & 246 \\
Duplicate acquisitions (first deal remains in sample) & -72 & 174 \\
Datastream / Worldscope data unavailable & -45 & 129 \\
Governance data unavailable & -59 & 70 \\
\hline Final Sample & & 70 \\
\hline
\end{tabular}

Final Sample

Panel C. Sample Distribution

\begin{tabular}{|c|c|c|c|c|c|c|c|}
\hline Years & 1998 & 1999 & 2000 & 2001 & 2002 & 2003 & 2004 \\
\hline No. of Transactions & 8 & 14 & 13 & 4 & 3 & 5 & 4 \\
\hline Years & 2005 & 2006 & 2007 & 2008 & 2009 & 2010 & 2011 \\
\hline No. of Transactions & 6 & 5 & 3 & 1 & 1 & 2 & 1 \\
\hline
\end{tabular}

In line with prior studies on earnings management preceding M\&A transactions, we consider a multi-period setting by investigating different periods prior to and after the deal announcement. Specifically, Botsari and Meeks (2008) find evidence that accruals manipulation starts already in the second year prior to the announcement of the actual deal. They argue that - even without having specific targets in mind - firms may set up acquisition

\footnotetext{
${ }^{110}$ Botsari and Meeks (2008), for example, allow for different target public statuses in their sample selection process but do not report results separately, whereas Erickson and Wang (1999) only consider public targets in their analyses. Nevertheless, consistent with Capron and Shen (2007), we assume that acquirers in transactions with public targets exhibit potentially greater incentives and greater opportunities to engage in accruals manipulation due to higher valuation uncertainty, higher degree of dispersed ownership and potentially weaker ties between managers and owners in public targets. In the robustness section, we address this issue by considering additionally private and subsidiary targets in order to assess the sensitivity of our sample selection choice.

${ }^{111}$ Using the last occurrence in cases of multiple transactions does not alter our main inferences.
} 
strategies several years prior to specific deal announcements. Moreover, assuming that our discretionary accrual measure is not affected by the actual deal, we expect to find on average a reversal in discretionary accruals in the years after the deal announcement. Overall, multiperiod analyses increase the sample size power. In the course of our analyses, we thus consider different periods prior to the deal announcement, i.e., TRANS-1, TRANS-1 to TRANS-2, TRANS-1 to TRANS-3, the period with the deal announcement, i.e., TRANS0, and different periods after the deal announcement, i.e., TRANS +1 , TRANS +1 to TRANS +2 , TRANS+1 to TRANS+3. For example, TRANS-1 (TRANS-2) indicates the acquirer's first (second) year with an earnings release preceding the announcement of the stock swap, whereas TRANS0 (TRANS+1) indicates the year with the acquirer's first (second) earnings release following the announcement of the stock swap. Figure 5 - 1 visualizes the underlying time structure with time periods (years) surrounding the announcement of the stock swap transactions. $^{112}$

Figure 5 - 1: Time Structure of M\&A Transactions

\section{EM-Period}

(Post) M\&A-Period

\begin{tabular}{|c|c|c|c|c|c|c|}
\hline & & & $\begin{array}{c}\text { Announcement } \\
\text { date }\left(T_{0}\right)\end{array}$ & & & \\
\hline TRANS-3 & TRANS- 2 & TRANS-1 & TRANS0 & TRANS +1 & TRANS +2 & TRANS +3 \\
\hline Earnings & Earnings & Earnings & Earnings release & Earnings & Earnings & Earnings \\
\hline release & release & release & in year ${ }_{0}$ & release & release & release \\
\hline in year $_{-3}$ & in year ${ }_{-2}$ & in year ${ }_{-1}$ & after $T_{0}$ & in year ${ }_{1}$ & in year ${ }_{2}$ & in year ${ }_{3}$ \\
\hline
\end{tabular}

Notes: This table presents the time structure, and the periods around the stock swap announcement. TRANS indicates the different periods (years) prior to and after the stock swap announcement. TRANS-1 (TRANS-2) [TRANS-3] presents the acquirer's first (second) [third] year with an earnings release preceding the stock swap announcement, whereas TRANS0 (TRANS+1) [TRANS+2] \{TRANS+3\} presents the year with the acquirer's first (second) [third] \{fourth \}earnings release following the stock swap announcement.

\subsubsection{Regression Model}

We address our hypothesis using the following regression model:

$$
\mathrm{DAC}_{\mathrm{it}}=\alpha+\gamma_{1} \mathrm{GOV}_{\mathrm{it}}+\sum \gamma_{2}{\mathrm{M} \& \mathrm{~A}_{-} \mathrm{CONTROL}_{\mathrm{it}}}+\sum \gamma_{3} \text { FIRM_CONTROL }_{\mathrm{it}}+\varepsilon
$$

\footnotetext{
${ }^{112}$ To identify the underlying time structure (periods surrounding the stock swap announcement), we measure the earnings release date by using the Worldscope item Earnings Announcement Date (wc05905). Alternative methods to identify the earnings release date do not alter our main findings. We add alternatively four months (three months) to a firm's fiscal year. The earnings release time lag (earnings release minus fiscal year end) for the UK acquirers in the Botsari and Meeks (2008) sample varies between two and four months.
} 
The dependent variable DAC stands for discretionary accruals obtained from an extended cross-sectional modified Jones model and measures accrual-based earnings management. GOV represents the main test variable and measures governance quality using a self-constructed score. Based on a sample of all acquirer-year observations corresponding to the period(s) with an earnings release preceding the announcement of the stock swap (i.e., TRANS- 1 with $\mathrm{N}=66$, TRANS- 1 to TRANS-2 with $\mathrm{N}=128$, TRANS- 1 to TRANS-3 with $\mathrm{N}$ $=188$ ), we assume consistent with our hypothesis that the coefficient estimate on $\gamma_{1}$ obtains a positive sign and becomes significant at conventional levels. M\&A_CONTROL represents a vector of M\&A characteristics which - motivated by prior literature (e.g., Baik et al., 2007; Erickson and Wang, 1999) - potentially affects discretionary accruals prior to the stock swap transaction (relative deal size, industrial relatedness between acquirer and target, and percentage of stock financing). Following prior earnings management literature (e.g., Koh et al., 2007; Bowen et al., 2008), FIRM_CONTROL is a vector of firm control variables including size, leverage, ownership, and audit quality. To address heteroskedasticity as well as cross-sectional and time-series dependence in the dataset, we use standard errors which are robust (White, 1980) and two-way clustered at firm and year level (Gow et al., 2010; Petersen, 2009).

\subsubsection{Discretionary Accruals}

Prior literature points out that the cross-sectional modified Jones model based on the cash flow approach is preferable in M\&A settings (Botsari and Meeks, 2008; Hribar and Collins, 2002). Two recent studies, however, argue that prior results on accruals manipulation preceding share deals are biased due to misspecified discretionary accruals (Pungaliya and Vijh, 2009; Collins et al., 2012). To address this possibility, we additionally adjust for growth in the estimation process of discretionary accruals. Consistent with Collins et al. (2012), we include a set of dummy variables indicating growth deciles to control for growth in our crosssectional modified Jones model. ${ }^{113}$ Following Ball and Shivakumar (2006, 2008), who stress the importance of incorporating timelier loss recognition in accrual models (and applying it to a UK IPO setting), we finally control for the potential non-linear relationship between accruals and cash flows by including CFO adjustments. Taken together, we measure

\footnotetext{
${ }^{113}$ In the robustness section, we show that a ROA and growth matching procedure as suggested in Collins et al. (2012) yields similar results. Since our yearly-based UK earnings management sample is substantially smaller compared to the quarterly-based U.S. sample used by Collins et al. (2012), we, however, favor the growth deciles approach described in section 5.4.3.
} 
discretionary accruals separately for each two-digit SIC industry group and year by the following model based on all available non-financial UK Worldscope firms (excluding the stock swap acquirers): ${ }^{114}$

$$
\begin{gathered}
\mathrm{CAC}_{\mathrm{it}} / \mathrm{TA}_{\mathrm{it}-1}=\alpha+\beta\left[\left(\Delta \mathrm{REV}_{\mathrm{it}} / \mathrm{TA}_{\mathrm{it}-1}\right)-\left(\Delta \mathrm{REC}_{\mathrm{it}} / \mathrm{TA}_{\mathrm{it}-1}\right)\right]+\sum_{\mathrm{n}=1}^{\mathrm{N}} \gamma_{\mathrm{n}} \mathrm{GROWTH}_{\text {nit }} \\
+\delta\left(\mathrm{CFO}_{\mathrm{it}} / \mathrm{TA}_{\mathrm{it}-1}\right)+\varphi \mathrm{DCFO}_{\text {it }}+\omega\left(\mathrm{CFO}_{\mathrm{it}} / \mathrm{TA}_{\mathrm{it}-1}\right) \times \mathrm{DCFO}_{\text {it }}+\varepsilon_{\mathrm{i}}
\end{gathered}
$$

The dependent variable CAC stands for current (working capital) accruals and is obtained directly from the cash flow statement (current accruals as net income minus cash from operations minus depreciation / amortization). $\triangle \mathrm{REV}$ stands for changes in revenues, $\triangle \mathrm{REC}$ stands for changes in receivables, $\mathrm{GROWTH}_{\mathrm{n}}$ represents $\mathrm{n}$ dummy variables indicating different growth deciles (based on the percentage change in sales), CFO stands for cash flows from operations, DCFO is a dummy variable indicating whether the CFO is smaller than zero, and TA stands for total assets. The residuals of regression equation 2 represent the unexpected (discretionary) accruals (DAC). In the robustness section, we repeat the main regression analysis by using alternative discretionary accrual types (DAC based on total accruals and with and without controlling for growth and CFO adjustments and DAC based on ROA and growth matching).

\subsubsection{Corporate Governance Proxy}

Our corporate governance proxy (GOV) measures the quality of internal corporate governance mechanisms (i.e., internal control and incentive mechanisms). Specifically, GOV is constructed as follows: In a first step, we construct a naïve corporate governance score (GOV $\mathrm{GSS}_{\text {ISS }}$ based on all UK Institutional Shareholder Services (ISS) Corporate Governance Quotient (CGQ) raw data for the years between 2003 and 2007. In doing so, we employ the CGQ raw dataset provided by ISS and the latest Corporate Governance Quotient Indicator Definition published by ISS in 2007 (RiskMetrics Group 2007). The UK CGQ rating relies on 47 single rating criteria and is organized into eight categories (board, audit, charter, antitakeover provisions, compensation, progressive practice, executive ownership, and

\footnotetext{
114 The constant term is not suppressed and thus the regression equations are not constructed through its origin (Botsari and Meeks, 2008, p. 637). Peasnell et al. (2000, p. 316), for example, state that there is no theoretical reason to suppress the constant term. In total, we run 784 industry-year regressions each - consistent with Botsari and Meeks $(2008$, p. 643) - with at least six observations. In particular, the distribution parameters of the corresponding sample sizes are as follows: mean value of sample size $=72$, median value of sample size $=42$, min value of sample size $=6$, max value of sample size $=293$, and total number of firm-year observations $=$ 21,253 .
} 
education). According to our $\mathrm{GOV}_{\text {ISS, }}$, each rating criterion takes the value of one if the firm's corporate governance standards are acceptable (based on the CGQ indicator definition), and zero otherwise (for a similar approach and an overview about UK ISS criteria, see Hitz and Lehmann, 2013).

In a second step, we take the firm's average value of GOV $\mathrm{GSS}_{\text {in }}$ in order to measure governance quality (GOV) for the M\&A sample period (1998 to 2011). This approach has its own merits and drawbacks. Using the CGQ raw dataset, we are able to measure internal corporate governance quality on a multi-dimensional level. However, to obtain a valid governance proxy, the approach relies on sticky governance structures. Based on year-to-year correlation coefficients between consecutive governance scores $\left(\mathrm{GOV}_{\mathrm{ISS}}\right)$, the stickiness level in the governance data is fairly high. ${ }^{115}$ In the robustness section, we run several tests to ensure the robustness of our governance proxy and to account for potential sample selection problems due to the availability of ISS data.

\subsubsection{Firm and M\&A Control Variables}

In line with prior literature, we use several variables to control for transaction-related earnings management incentives (M\&A_CONTROL) as well as for firm characteristics (FIRM_CONTROL) to ensure the specification power of our main regression model.

In particular, we control for the acquirer's pricing uncertainty by using relative deal size (DEAL SIZE) as transaction value deflated by acquirers' market value of equity as well as industrial relatedness between the acquirer and the target (IND RELATEDNESS) as a dummy variable indicating whether the four-digit SIC code of the acquirer and the target is identical (Baik et al., 2007; Erickson and Wang, 1999), and deal financing (STOCK) by using a variable indicating the percentage of stock of the deal financing (Baik et al., 2007).

As firm control variables, we consider additionally firm size (SIZE) by using the natural logarithm of firms' total assets (e.g., Klein, 2002), potential agency costs of debt (LEV) by using the relation of total debt to total assets (DeFond and Jiambalvo, 1994), ownership

\footnotetext{
${ }^{115}$ Prior literature commonly assumes stickiness in firm-level corporate governance. Brown et al. (2011), for example, provide year-to-year correlation coefficients for Australian governance rankings over eight years from 2002 to 2009 which ranges on a relatively high level between 0.72 and 0.89 . Likewise, Daines et al. (2010) report - with a correlation coefficient of 0.85 between two consecutive US CGQ ratings - a relatively high stickiness level of governance. Following the notion of sticky governance structures, prior governance studies extend their sample backwards and assume constant governance quality over time (Bauer et al., 2004; Drobetz et al., 2004). The stickiness level in our dataset (expressed by year-to-year correlation coefficients based on a balanced panel sample) is similar to Brown et al. (2011) and Daines et al. (2010) on a comparably high level, ranging from 0.45 to 0.93 with an average value of 0.67 .
} 
(OWNER) by using a summary measure of closely held shares (Koh et al., 2007), and audit quality (BIG FIVE) by using a dummy variable indicating whether the firm is audited by one of the Big Five auditors or their predecessors (Lennox and Pittman, 2010). ${ }^{116}$ In the robustness section, we show that our main findings are unaffected by the inclusion of additional (M\&A and firm) control variables and by using stepwise regression techniques to statistically select the control variables.

\subsection{Results}

\subsubsection{Descriptive Statistics}

Table 5 - 3 presents descriptive statistics for the respective year of the stock swap announcement (TRANS0) for all variables used in this study. In particular, discretionary accruals are on average $-0.42 \%$ (discretionary accruals to lagged total assets) and range on a scale between $-53.45 \%$ and $43.06 \%$ at the time of the stock swap announcement. Governance quality measured by GOV - with a theoretical range between 0 (worst) and 100 (best governance quality) - provides sufficient dispersion for further analyses with a standard deviation of $24.98 \%$ around the mean of $45.09 \%$. The relative deal size distribution is slightly rightskewed with a mean value of $102.47 \%$ and a median value of $58.32 \%$ (with relative deal size as deal value deflated by acquirer's market value). All transactions are either pure stock swaps or mixed deals with explicitly identifiable share elements. Specifically, the percentage of stock financing ranges between $8.22 \%$ and $100 \%$ with a mean (median) value of $80.69 \%$ $(98.28 \%)$.

Table 5 - 4 reports non-parametric Spearman and Pearson correlation coefficients between the main interest variables (DAC and GOV) and all test variables as well as control variables. In contrast to the descriptive statistics, the correlations are based on the acquirer's first year with an earnings release preceding the announcement of the stock swap (TRANS-1). In line with our hypothesis, governance quality is positively correlated with discretionary accruals in the period prior to the announcement of the stock swap transactions, yet, not on a statistically meaningful level. In addition, all remaining correlations between discretionary

\footnotetext{
${ }^{116}$ As our proxy of internal governance (GOV) does not incorporate any external audit quality measures, we control for audit quality separately. Following Larcker et al. (2007, p. 987), we do not control for growth and/or performance in our final regression model. To the extent that our abnormal accruals are orthogonal to growth and performance due to the applied discretionary accrual model, we do not consider such variables in our final setup. However, within the robustness section, we test among other things whether additional (firm and M\&A) control variables affect our main findings. In addition, Appendix 5 - 14 provides an overview of all variables used in our study.
} 
accruals and firm as well as M\&A control variables remain insignificant in the period leading up to the stock swap announcement.

Table 5 - 3: Descriptive Analysis

\begin{tabular}{|c|c|c|c|c|c|}
\hline $\begin{array}{l}\text { Descriptive values } \\
\text { (TRANSO) }\end{array}$ & Mean & Median & St.Dev. & Min. & Max. \\
\hline \multicolumn{6}{|l|}{ EARNINGS MANAGEMENT \& GOVERNANCE } \\
\hline $\begin{array}{l}\text { Acquirer's Discretionary Accruals (DAC in \%) } \\
\text { Acquirer's Governance Quality (GOV in \%) }\end{array}$ & $\begin{array}{l}-0.42 \\
45.09 \\
\end{array}$ & $\begin{array}{l}-0.69 \\
44.96 \\
\end{array}$ & $\begin{array}{l}17.08 \\
24.98\end{array}$ & $\begin{array}{c}-53.45 \\
2.37 \\
\end{array}$ & $\begin{array}{l}43.06 \\
88.66\end{array}$ \\
\hline \multicolumn{6}{|l|}{ FIRM CONTROLS } \\
\hline $\begin{array}{l}\text { Acquirer's Total Assets (in } € \text { Mill.) } \\
\text { Acquirer's Market Value (in } € \text { Mill.) } \\
\text { Acquirer's Leverage (LEV in \%) } \\
\text { Acquirer's Ownership (OWNER in \%) } \\
\text { Acquirer's Audit Quality (BIG FIVE) } \\
\end{array}$ & $\begin{array}{l}3,315 \\
6,758 \\
22.17 \\
13.73 \\
.9571 \\
\end{array}$ & $\begin{array}{c}817 \\
821 \\
20.52 \\
10.08 \\
1 \\
\end{array}$ & $\begin{array}{c}5,821 \\
22,111 \\
18.28 \\
15.62 \\
.2039 \\
\end{array}$ & $\begin{array}{c}7.5 \\
10.65 \\
0 \\
.01 \\
0 \\
\end{array}$ & $\begin{array}{c}28,400 \\
153,404 \\
75.58 \\
64.22 \\
1 \\
\end{array}$ \\
\hline \multicolumn{6}{|l|}{ M\&A CONTROLS } \\
\hline $\begin{array}{l}\text { Deal-Value (in } € \text { Mill.) } \\
\text { Relative Deal Value (DEAL SIZE in \%) } \\
\text { Industrial Relatedness (IND RELATEDNESS) } \\
\text { Percentage of Stock (STOCK) }\end{array}$ & $\begin{array}{c}5,508 \\
102.47 \\
.6428 \\
80.69 \\
\end{array}$ & $\begin{array}{c}328 \\
58.32 \\
1 \\
98.28 \\
\end{array}$ & $\begin{array}{c}25,994 \\
267.16 \\
.4826 \\
23.71 \\
\end{array}$ & $\begin{array}{c}3.25 \\
1.21 \\
0 \\
8.22 \\
\end{array}$ & $\begin{array}{c}204,792 \\
2,226 \\
1 \\
100 \\
\end{array}$ \\
\hline
\end{tabular}

Notes: This table displays the descriptive statistics of all variables used on this study. The sample consists of 70 stock swap transactions. For details on the sample selection process, see Table $5-2$. For detailed information and definitions of the variables, see Appendix 5 - 14.

Table 5 - 4: Correlation Analysis

\begin{tabular}{|c|c|c|c|c|c|c|c|c|c|c|}
\hline \multirow{2}{*}{$\begin{array}{l}\text { TRANS-1 } \\
(\mathrm{N}=66)\end{array}$} & & \multicolumn{9}{|c|}{ Correlations (Spearman \& Pearson) } \\
\hline & & 1 & 2 & 3 & 4 & 5 & 6 & 7 & 8 & 9 \\
\hline DAC & 1 & & $\begin{array}{c}.155 \\
(0.22)\end{array}$ & $\begin{array}{c}-.101 \\
(0.42)\end{array}$ & $\begin{array}{c}-.135 \\
(0.28)\end{array}$ & $\begin{array}{c}.057 \\
(0.65)\end{array}$ & $\begin{array}{c}-.100 \\
(0.42)\end{array}$ & $\begin{array}{c}-.099 \\
(0.43)\end{array}$ & $\begin{array}{l}-.127 \\
(0.31)\end{array}$ & $\begin{array}{c}.203 \\
(0.10)\end{array}$ \\
\hline GOV & 2 & $\begin{array}{c}.096 \\
(0.44) \\
\end{array}$ & & $\begin{array}{c}.037 \\
(0.77) \\
\end{array}$ & $\begin{array}{c}.035 \\
(0.78) \\
\end{array}$ & $\begin{array}{c}-.062 \\
(0.62)\end{array}$ & $\begin{array}{c}.175 \\
(0.16) \\
\end{array}$ & $\begin{array}{l}-.3^{* * *} \\
(0.00) \\
\end{array}$ & $\begin{array}{l}.50^{* * * *} \\
(0.00)\end{array}$ & $\begin{array}{l}.175 \\
(0.16) \\
\end{array}$ \\
\hline DEAL SIZE & 3 & $\begin{array}{c}.089 \\
(0.48)\end{array}$ & $\begin{array}{c}.087 \\
(0.49)\end{array}$ & & $\begin{array}{c}.112 \\
(0.37)\end{array}$ & $\begin{array}{c}-.032 \\
(0.80)\end{array}$ & $\begin{array}{c}.029 \\
(0.82)\end{array}$ & $\begin{array}{c}.080 \\
(0.53)\end{array}$ & $\begin{array}{c}-.229^{*} \\
(0.06)\end{array}$ & $\begin{array}{c}.004 \\
(0.97)\end{array}$ \\
\hline IND RELATEDNESS & 4 & $\begin{array}{c}-.090 \\
(0.47)\end{array}$ & $\begin{array}{c}.033 \\
(0.79)\end{array}$ & $\begin{array}{c}.104 \\
(0.41)\end{array}$ & & $\begin{array}{c}.015 \\
(0.90)\end{array}$ & $\begin{array}{l}-.134 \\
(0.28)\end{array}$ & $\begin{array}{l}-.072 \\
(0.57)\end{array}$ & $\begin{array}{l}.292^{* *} \\
(0.02)\end{array}$ & $\begin{array}{c}.030 \\
(0.81)\end{array}$ \\
\hline STOCK & 5 & $\begin{array}{c}.061 \\
(0.63) \\
\end{array}$ & $\begin{array}{c}-.048 \\
(0.70)\end{array}$ & $\begin{array}{c}.095 \\
(0.45)\end{array}$ & $\begin{array}{c}.015 \\
(0.91) \\
\end{array}$ & & $\begin{array}{c}-.148 \\
(0.24)\end{array}$ & $\begin{array}{c}-.169 \\
(0.18) \\
\end{array}$ & $\begin{array}{c}-.039 \\
(0.75)\end{array}$ & $\begin{array}{c}-.22 * \\
(0.08) \\
\end{array}$ \\
\hline BIG FIVE & 6 & $\begin{array}{c}-.084 \\
(0.51)\end{array}$ & $\begin{array}{c}.181 \\
(0.15)\end{array}$ & $\begin{array}{c}.019 \\
(0.88)\end{array}$ & $\begin{array}{c}-.134 \\
(0.28)\end{array}$ & $\begin{array}{c}-.168 \\
(0.18)\end{array}$ & & $\begin{array}{l}-0.108 \\
(0.39)\end{array}$ & $\begin{array}{l}.267^{* *} \\
(0.03)\end{array}$ & $\begin{array}{c}.207 \\
(0.10)\end{array}$ \\
\hline OWNER & 7 & $\begin{array}{c}-.089 \\
(0.48)\end{array}$ & $\begin{array}{c}-.25^{* *} \\
(0.04)\end{array}$ & $\begin{array}{c}.049 \\
(0.69)\end{array}$ & $\begin{array}{c}-.046 \\
(0.72)\end{array}$ & $\begin{array}{c}-.193 \\
(0.12)\end{array}$ & $\begin{array}{l}-.116 \\
(0.35)\end{array}$ & & $\begin{array}{l}-.5 * * * \\
(0.00)\end{array}$ & $\begin{array}{c}-.079 \\
(0.53)\end{array}$ \\
\hline SIZE & 8 & $\begin{array}{c}-.099 \\
(0.43)\end{array}$ & $\begin{array}{l}.49 * * * \\
(0.00)\end{array}$ & $\begin{array}{c}-.067 \\
(0.59)\end{array}$ & $\begin{array}{l}.281^{* *} \\
(0.02)\end{array}$ & $\begin{array}{l}-.070 \\
(0.57)\end{array}$ & $\begin{array}{l}.269^{* *} \\
(0.03)\end{array}$ & $\begin{array}{r}-.33^{* *} \\
(0.01)\end{array}$ & & $\begin{array}{l}.25 * * \\
(0.04)\end{array}$ \\
\hline LEV & 9 & $\begin{array}{c}.181 \\
(0.15) \\
\end{array}$ & $\begin{array}{c}.191 \\
(0.12) \\
\end{array}$ & $\begin{array}{c}-.025 \\
(0.84) \\
\end{array}$ & $\begin{array}{c}-.005 \\
(0.97) \\
\end{array}$ & $\begin{array}{r}-.27 * * \\
(0.03)\end{array}$ & $\begin{array}{l}.251^{* *} \\
(0.04)\end{array}$ & $\begin{array}{l}-.196 \\
(0.11) \\
\end{array}$ & $\begin{array}{l}.314^{* *} \\
(0.01)\end{array}$ & \\
\hline
\end{tabular}

Notes: This table reports Pearson correlation coefficients (above the diagonal) and non-parametric Spearman correlation coefficients (below the diagonal). For detailed information and definitions of the variables, see Appendix 5 - 14. Reported values: coefficients (p-values), ${ }^{* *}\left({ }^{* *}\right)\left({ }^{*}\right)$ indicates significance levels at $1 \%(5 \%)$ $(10 \%)$, two-tailed level.

Table 5 - 5 presents distribution characteristics of the acquirer's discretionary accruals in the periods surrounding the stock swap transactions, and provides significance tests of the mean (t-test) and the median (Wilcoxon signed-ranks test) values (e.g., Botsari and Meeks, 2008, p. 649). Consistent with prior findings, our results suggest that acquirers on average manipulate accruals upward prior to stock swap transactions. Specifically, the mean and 
median discretionary accrual values in the first year preceding the stock swap announcement (TRANS-1) are positive and significant at conventional levels (Table 5 - 5, Panel A). Moreover, we find evidence of the reversion of accruals manipulation in the year of the acquirer's second earnings release following the stock swap announcement (TRANS +1$)$ (Table 5 - 5, Panel A). ${ }^{117}$ Consistent with our hypothesis, we find evidence suggesting that acquirers with strong governance engage more aggressively in income-increasing accruals manipulation than those with weak governance do (Table 5-5, Panel B and C). Well governed acquirers exhibit on average 3.4\% discretionary accruals to firm's total assets in the first year prior to the deal announcement (Table 5 - 5, Panel B), whereas acquirers with weak governance exhibit on average only $1.8 \%$ discretionary accruals to firm's total assets in the same period (Table 5 - 5, Panel C).

Table 5 - 5: Mean and Median DAC Analyses

Panel A. Mean / Median DAC around Stock Swaps: full sample (all GOV rated stock swaps)

\begin{tabular}{ccccccc}
\hline Time / Var & Mean & Median & SD & Min. & Max. \\
\hline TRANS-3 & 0.0219 & 0.0000 & 0.0886 & -0.1737 & 0.4307 & 0.4307 \\
TRANS-2 & 0.0150 & 0.0071 & 0.1276 & -0.5345 & 62 \\
TRANS-1 & $\mathbf{0 . 0 2 6 0 * * *}$ & $\mathbf{0 . 0 1 7 9 * * *}$ & $\mathbf{0 . 0 7 2 7}$ & $\mathbf{- 0 . 1 8 8 5}$ & $\mathbf{0 . 2 5 3 9}$ \\
TRANS0 & -0.0042 & -0.0069 & 0.1708 & -0.5345 & 0.4307 \\
TRANS+1 & $\mathbf{- 0 . 0 1 6 1 *}$ & $\mathbf{0 . 0 0 0 0}$ & $\mathbf{0 . 0 9 5 7}$ & $\mathbf{- 0 . 5 3 4 5}$ & $\mathbf{0 . 1 7 2 0}$ \\
TRANS+2 & -0.0138 & 0.0001 & 0.0946 & -0.4644 & 0.1558 \\
TRANS+3 & 0.0072 & 0.0039 & 0.0819 & -0.3979 & 0.1479 \\
\hline
\end{tabular}

Panel B. Mean / Median DAC around Stock Swaps: above mean GOV rated stock swaps

\begin{tabular}{ccccccc}
\hline Time $/$ Var & Mean & Median & SD & Min. & Max. \\
\hline TRANS-3 & 0.0196 & 0.0003 & 0.0717 & -0.1737 & 0.1913 \\
TRANS-2 & $0.0388^{* *}$ & $0.0109 * *$ & 0.1059 & -0.1455 & 0.4307 \\
TRANS-1 & $\mathbf{0 . 0 3 4 4 * * *}$ & $\mathbf{0 . 0 2 4 9 * *}$ & $\mathbf{0 . 0 7 4 4}$ & $\mathbf{- 0 . 0 7 6 5}$ & $\mathbf{0 . 2 5 3 9}$ \\
TRANS0 & 0.0362 & 0.0000 & 0.1545 & -0.2029 & 0.4307 \\
TRANS+1 & $\mathbf{- 0 . 0 2 3 5}$ & $\mathbf{0 . 0 0 0 0}$ & $\mathbf{0 . 1 1 3 2}$ & $\mathbf{- 0 . 5 3 4 5}$ & $\mathbf{0 . 1 2 3 2}$ \\
TRANS+2 & -0.0128 & 0.0000 & 0.1091 & -0.4644 & 0.1558 \\
TRANS+3 & 0.0140 & 0.0087 & 0.0591 & -0.1195 & 0.1465 \\
\hline
\end{tabular}

Panel C. Mean / Median DAC around Stock Swaps: below mean GOV rated stock swaps

\begin{tabular}{ccccccc}
\hline Time $/$ Var & Mean & Median & SD & Min. & Max. \\
\hline TRANS-3 & 0.0241 & 0.0000 & 0.1031 & -0.1487 & 0.4307 & 0.2641 \\
TRANS-2 & -0.0089 & 0.0000 & 0.1439 & -0.5345 & $\mathbf{0}$ \\
TRANS-1 & $\mathbf{0 . 0 1 7 7 *}$ & $\mathbf{0 . 0 1 6 3 *}$ & $\mathbf{0 . 0 7 1 1}$ & $\mathbf{- 0 . 1 8 8 5}$ & $\mathbf{0 . 1 4 0 6}$ \\
TRANS0 & $-0.0471^{*}$ & -0.0110 & 0.1789 & -0.5345 & 0.1600 & $\mathbf{0 . 1 7 2 0}$ \\
TRANS+1 & $\mathbf{- 0 . 0 0 8 4}$ & $\mathbf{- 0 . 0 0 3 9}$ & $\mathbf{0 . 0 7 3 8}$ & $\mathbf{- 0 . 1 8 3 0}$ & 31 \\
TRANS+2 & -0.0148 & 0.0051 & 0.0781 & -0.1924 & 0.1085 \\
TRANS+3 & -0.0005 & 0.0018 & 0.1026 & -0.3979 & 0.1479 \\
\hline
\end{tabular}

Notes: This table presents distribution characteristics of acquirer's discretionary accruals in the periods around the stock swap announcement (for different samples). TRANS indicates the different periods (years) prior to and after the stock swap announcement. TRANS-1 (TRANS-2) [TRANS-3] presents the acquirer's first (second) [third] year with an earnings release preceding the stock swap announcement, whereas TRANS0 (TRANS+1) [TRANS +2 ] $\{$ TRANS +3$\}$ presents the year with the acquirer's first (second) [third] \{fourth\} earnings release following the stock swap announcement. The significance tests are based on t-test statistics (for the mean values) and Wilcoxon signed-ranks test statistics (for the median values). ${ }^{* * *}(* *)(*)$ indicates significance levels at $1 \%$ $(5 \%)(10 \%)$, one-tailed.

${ }^{117}$ However, as Louis (2004) and Botsari and Meeks (2008) point out, discretionary accruals after the transaction (TRANS+1) have to be carefully interpreted since M\&A deals affect the acquirers' balance sheet in complex ways so that changes in accruals in this period are rather difficult to compare. 
Figure 5 - 2 visualizes the accruals manipulation separately for acquirers with strong and weak governance around the stock swap announcements (the median values are taken from Table 5 - 5, Panel A, B, and C). In the period leading up to the announcement date (i.e., TRANS-2 and TRANS-1), acquirers with strong governance exhibit on average higher discretionary accruals than their counterparts with weak governance do.

Figure 5 - 2: Distribution of Median DAC around UK Stock Swap Transactions

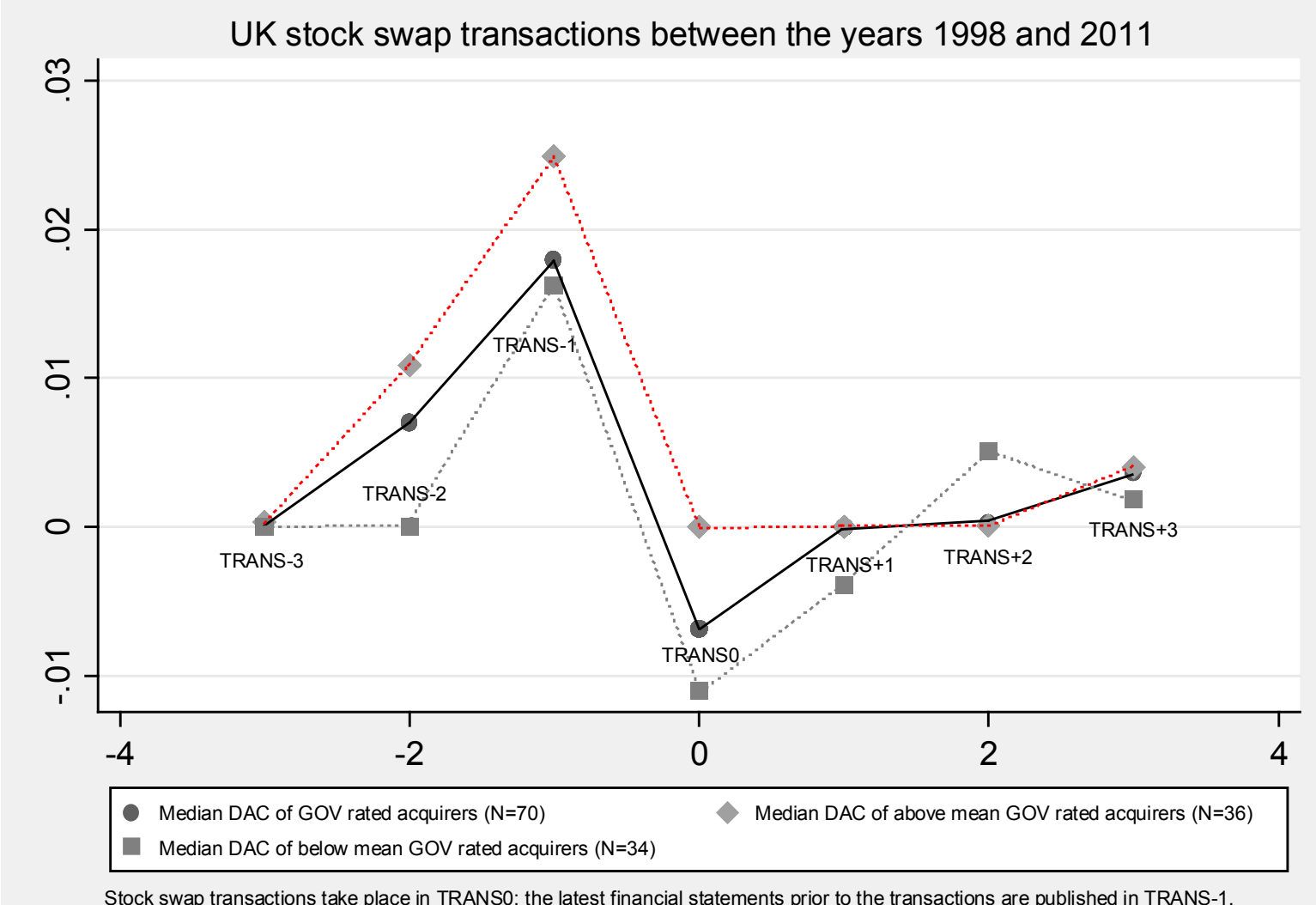

Notes: This figure presents the distribution of the acquirer's median discretionary accruals (DAC) in the periods around the stock swap announcements. For details on the sample selection process, see Table 5 - 2 . The DAC median values are taken from Table 5 - 5. TRANS indicates the different periods (years) prior to and after the stock swap announcement. TRANS-1 (TRANS-2) [TRANS-3] presents the acquirer's first (second) [third] year with an earnings release preceding the stock swap announcement, whereas TRANS0 (TRANS+1) [TRANS+2] $\{$ TRANS +3 \} presents the year with the acquirer's first (second) [third] \{fourth\} earnings release following the stock swap announcement.

\subsubsection{Regression Results}

Table 5 - 6 presents the regression results. Model 1 to 3 investigate the relationship between corporate governance and discretionary accruals in the period(s) prior to the stock swap announcement, with Model 1 addressing the first period (TRANS-1), Model 2 the first and second period (TRANS-1 to TRANS-2), and Model 3 the first, second, and third period (TRANS-1 to TRANS-3) prior to the stock swap announcement. In the same logic, Model 4 
to 6 address the relationship between governance and earnings management in the period(s) after the stock swap announcement. In particular, all governance coefficients in the first three models obtain a positive sign and become significant at conventional levels (at the 5\% and $1 \%$ level). We therefore find evidence in line with our hypothesis that good corporate governance promotes income-increasing, accrual-based earnings management in the period(s) prior to the announcement of the stock swap. According to the results of the period(s) after the stock swap announcement (and completion), the governance coefficients become insignificant and obtain a negative sign in one out of three models (Table 5 - 6, Model 4 and 6). These findings even underline the economic implications of the governance results across the periods prior to the deal, since the observed governance-accruals relationship appears to be period specific and does not follow any systematic pattern across the whole sample.

Table 5 - 6: Regression Analyses: Governance Role

\begin{tabular}{|c|c|c|c|c|c|c|}
\hline \multirow{4}{*}{ Variables } & \multicolumn{6}{|c|}{ Dependent variable: Discretionary Accruals (CMJM with CFO \& Growth adj./ CAC) } \\
\hline & \multicolumn{3}{|c|}{ Periods prior to the Stock Swap Transaction } & \multicolumn{3}{|c|}{ Periods after the Stock Swap Transaction } \\
\hline & TRANS-1 & TRANS-1/-2 & TRANS-1/-3 & TRANS+1 & TRANS+1/+2 & TRANS+1/+3 \\
\hline & Model 1 & Model 2 & Model 3 & Model 4 & Model 5 & Model 6 \\
\hline \multirow[t]{2}{*}{ Intercept } & $.2251 * *$ & $.2550 * * *$ & $.2617 * * *$ & $-.1097 *$ & -.0284 & -.0375 \\
\hline & $(2.79)$ & $(2.63)$ & $(2.67)$ & $(-1.84)$ & $(-0.70)$ & $(-0.54)$ \\
\hline \multirow[t]{2}{*}{ GOV } & $.0843 * *$ & $.1213 * *$ & $.1058 * * *$ & -.0152 & .0157 & .0226 \\
\hline & $(2.28)$ & $(2.44)$ & (2.81) & $(-0.28)$ & $(0.25)$ & $(0.53)$ \\
\hline \multirow[t]{2}{*}{ DEAL SIZE } & $-.0001 * * *$ & -.0000 & -.0000 & -.0000 & $-.0000 * *$ & -.0000 \\
\hline & $(-5.86)$ & $(-1.37)$ & $(-1.08)$ & $(-0.02)$ & $(-2.42)$ & $(-0.82)$ \\
\hline \multirow[t]{2}{*}{ IND RELATEDNESS } & -.0127 & .0083 & .0069 & .0128 & .0296 & .0218 \\
\hline & $(-0.66)$ & $(0.41)$ & $(0.44)$ & $(0.32)$ & $(1.23)$ & $(1.08)$ \\
\hline \multirow[t]{2}{*}{ STOCK } & .0002 & -.0001 & .0001 & .0001 & -.0001 & -.0000 \\
\hline & $(0.71)$ & $(-0.27)$ & $(0.43)$ & $(0.12)$ & $(-0.14)$ & $(-0.01)$ \\
\hline \multirow[t]{2}{*}{ BIG FIVE } & -.0474 & $-.1663 * * *$ & $-.1740 * *$ & .0323 & .0087 & .0456 \\
\hline & $(-0.67)$ & $(-3.57)$ & $(-2.40)$ & $(1.65)$ & $(0.29)$ & $(0.82)$ \\
\hline \multirow[t]{2}{*}{ OWNER } & $-.0047^{*}$ & -.0026 & -.0027 & .0018 & -.0019 & -.0008 \\
\hline & $(-2.15)$ & $(-0.57)$ & $(-0.92)$ & $(0.47)$ & $(-0.39)$ & $(-0.21)$ \\
\hline \multirow[t]{2}{*}{ SIZE } & $-.0160 * * *$ & $-.0103 *$ & $-.0107 * *$ & .0025 & -.0014 & -.0032 \\
\hline & $(-4.87)$ & $(-1.78)$ & $(-2.12)$ & $(0.30)$ & $(-0.30)$ & $(-0.91)$ \\
\hline \multirow[t]{2}{*}{ LEV } & $.1068 * *$ & .0755 & .0623 & $.0742 *$ & .0411 & .0378 \\
\hline & $(2.19)$ & $(1.18)$ & $(1.40)$ & $(1.80)$ & $(0.67)$ & $(1.01)$ \\
\hline Clustered se (1w) & Yes & No & No & Yes & No & No \\
\hline Clustered se (2w) & No & Yes & Yes & No & Yes & Yes \\
\hline Adj. $R^{2}$ & .1073 & .0937 & .1213 & -.0966 & -.0215 & -.0060 \\
\hline Sample Size & 66 & 128 & 188 & 67 & 130 & 189 \\
\hline
\end{tabular}

Notes: The underlying regression model is:

$$
\text { DAC }_{i t}=\alpha+\gamma_{1} \text { GOV }_{\text {it }}+\sum \gamma_{2} \text { M\&A_CONTROL }_{i t}+\sum \gamma_{3} \text { FIRM_CONTROL }_{\text {it }}+\varepsilon
$$

Where $\alpha$ represents the constant term, $\gamma_{1}-\sum \gamma_{3}$ are the coefficients of the explanatory variables, and $\varepsilon$ is the error term. The dependent variable DAC represents discretionary accruals obtained from an extended (CFO and growth adjusted) cross-sectional modified Jones model and measures accrual-based earnings management. GOV proxies firm-level governance quality. M\&A_CONTROL represents a vector of M\&A characteristics (relative deal size, industrial relatedness, and percentage of stock financing). FIRM_CONTROL represents a vector of firm characteristics (size, leverage, ownership concentration, and big five auditor). For detailed information and definitions of the variables, see Appendix 5 - 14. The regression models have standard errors which are heteroskedasticity robust and - as indicated - one-way clustered at year level or two-way clustered at firm and year level. Reported values: coefficient (t-value) $* * *(* *)(*)$ indicates significance levels at $1 \%(5 \%)(10 \%)$, two-tailed. 
With respect to our control variables, we find in the first period prior to the deal announcement (TRANS-1) that relative deal size (at the 1\% level), acquirer's firm size (at a $1 \%$ level), acquirer's leverage (at a 5\% level), and the acquirer's ownership structure (at a $10 \%$ level) are significantly associated with acquirer's discretionary accruals (Table 5 - 6, Model 1). The signs of the three latter control variables are in line with prior literature on earnings management and governance (e.g., Klein, 2002). The sign of relative deal size confirms the results of Baik et al. (2007) that acquirer's pricing uncertainty might induce incentives for earnings management. ${ }^{118}$ However, this in turn contradicts Erickson and Wang (1999) who argue that with increasing deal ratios higher economic benefits trigger accruals manipulation prior to the deal. ${ }^{119}$

In addition, across both panels covering the first two and three periods prior to the deal announcement (TRANS-1 to TRANS-2 and TRANS-1 to TRANS-3), we find evidence that acquirer's audit quality (at a 5\% and 1\% level) is significantly and negatively associated with accruals manipulation (Table 5 - 6, Model 2 and 3). This finding might be surprising since the results suggest that strong internal governance promotes accruals manipulation, while external audit quality measured by the presence of one of the big five audit firms constrains the same. Consistent with our hypothesis, we take this as evidence of the complexity of governance structures, especially with respect to internal and external governance provisions and with the ability of these provisions to primarily solve conflicts between ownership and control or conflicts between current and future shareholders. ${ }^{120}$ Overall, our findings suggest that - in line with our hypothesis - well governed acquirers engage more aggressively in incomeincreasing accruals manipulation than those with weak governance prior to the deal announcement.

\footnotetext{
${ }^{118}$ Using log of offer price instead of relative deal size does not alter our governance results.

${ }^{119}$ Incentives to manipulate earnings might be an increasing function of lower reputational risk, lower litigation risk, and the decreasing probability that earnings management is detected. Assuming that reputational and litigation risk as well as the probability of earnings management detection is increasing with the deal ratio (due to more consultancy resource employed by the target and a potentially higher media and analyst coverage), we would in turn expect lower incentives to engage in accruals manipulation prior to transactions with higher deal ratios.

${ }^{120}$ Our corporate governance proxy does not incorporate any external audit quality measures. The ISS raw data only contains information on three related internal audit quality measures: (1) audit committee composition is $100 \%$ independent, (2) policy disclosed regarding auditor rotation, and (3) consulting fees are less than audit fees (for details on the UK ISS rating criteria, see Hitz and Lehmann, 2013, p. 38).
} 


\subsubsection{Additional Analyses and Robustness Tests}

\section{Buy-and-Hold Abnormal Returns}

We perform several analyses to test the robustness of our findings. First, following Botsari and Meeks (2008), we investigate abnormal returns around the deal announcement and thereby address an implicit assumption of our setting; acquirers engage in income-increasing accruals manipulation to temporarily inflate their stock prices prior to the deal announcement. We thus estimate (long-term) buy-and-hold abnormal returns (BHARs) for our sample firms (Barber and Lyon, 1997; Lyon et al., 1999; Louis, 2004; Kothari and Warner, 2006; Botsari and Meeks, 2008). In particular, we follow the approach proposed by Barber and Lyon (1997, pp. 344,355$)$ and estimate the BHARs as follows:

$$
B H A R_{i T}=\prod_{t=1}^{T}\left[1+R_{i t}\right]-\prod_{t=1}^{T}\left[1+E\left(R_{i t}\right)\right]
$$

$\mathrm{BHAR}_{\mathrm{iT}}$ is the buy-and-hold abnormal return of firm $\mathrm{i}$ over a period of T months. $\mathrm{R}_{\mathrm{it}}-$ as the firm's simple return (Barber and Lyon, 1997, p. 349) - is defined as the change in stock prices plus dividends divided by last year's stock price. $E\left(R_{i t}\right)$ is the expected return of firm $i$ at month $\mathrm{t}$ measured as the simple return of a control firm at month $\mathrm{t}$. Following Barber and Lyon (1997, p. 355), we choose the control firms as follows: (1) we identify all non-stock acquirers with a market value of equity between $70 \%$ and $130 \%$ of the market value of equity of each acquirer (yearly-based); (2) from the acquirer's individual matching portfolio, we select the non-stock acquirer with the book-to-market ratio closest to that of the acquirer. In line with the implicit assumption of inflating stocks' purchasing power (Heron and Lie, 2002, p. 137), we expect to find positive BHARs for acquiring firms in the period leading up to the deal announcements.

Untabulated results reveal that acquirers earn on average significantly positive abnormal returns in the period (TRANS-1) prior to the deal announcement. Moreover, we see that acquirers with above average governance quality earn higher BHARs in that specific period (TRANS-1) compared to those with below mean governance quality. We further see that acquirers earn abnormal returns in different periods (12 months, 24 months, and 36 months) prior to the deal announcement month, and that acquirers with above average accruals manipulation (and higher governance quality) earn higher abnormal returns in these periods compared to those with lower level of discretionary accruals (and governance quality). ${ }^{121}$ Our

\footnotetext{
${ }^{121}$ See Appendix 5 - 1.
} 
BHAR analyses thus suggest that acquirers potentially succeed in inflating stock prices prior to share deals and that - consistent with our hypothesis - well governed acquirers are even more successful in inflating their stocks' purchasing power.

\section{Cash Acquirers}

Second, in line with Erickson and Wang (1999) and Botsari and Meeks (2008), we challenge the overall robustness of our findings and the theoretical underpinning of our setting by replicating the main analyses for cash acquirers. Since cash transactions differ to stock swap deals in that they do not rely on exchange ratios, inflated share prices (e.g., due to accruals manipulation) should not directly affect target prices in cash transactions. Moreover, cash transactions do not create any earnings or control right dilutions for the acquirer's existing shareholders. Consequently, we neither expect managerial incentives to engage in accruals manipulation prior to cash transactions nor shareholder incentives to incentivize management for short-term stock performance, and accruals manipulation. Using the SDC database and applying the same selection procedure as reported in section 5.4.1 - with the only exception being that only $100 \%$ cash acquisitions are considered - we obtain a final sample of 64 cash acquirers. Untabulated results reveal that cash acquirers do not engage in income-increasing accruals manipulation in the period prior to the announcement of the cash deal. The results further suggest that governance quality does not systematically explain the variation in the acquirer's discretionary accruals in the periods surrounding the announcement date. In addition, analyses of cash acquirers' buy-and-hold abnormal returns do not reveal positive and significant abnormal returns in the period prior to the deal announcement. Likewise, they do not suggest that corporate governance and / or accruals manipulation affect the level of BHARs. $^{122}$

\section{Sample Selection Bias}

Third, we control for a possible sample selection bias in our regression analysis (Table 5 - 6). Since the final sample $(\mathrm{N}=70)$ is selected by the availability of ISS data on governance quality, we apply a two-stage Heckman procedure to model the selection process based on a sample that contains all transactions independently of whether governance data is available or

\footnotetext{
${ }^{122}$ See Appendix 5 - 2 to Appendix 5 - 5.
} 
not $(\mathrm{N}=129)$. We adjust the regression models from Table 5 - 6 for the selection effect by including the inverse Mills ratio from a first stage probit regression. Untabulated results of the extended regressions are in line with our original findings. In all regressions addressing the period(s) prior to the deal announcement the governance coefficients obtain positive signs and remain significant at conventional levels (at a $1 \%$ and $5 \%$ level). The inverse mills ratio, however, remains insignificant across the different regressions. ${ }^{123}$

\section{Target Public Status}

Fourth, we additionally consider private and subsidiary targets to assess the sensitivity of our sample selection choice. Baik et al. (2007) and Pungaliya and Vijh (2009) examine stock swap transactions with private (and subsidiary) targets and argue that the information asymmetry risk for bidders might be higher in transactions with non-public targets, and that managers of public targets might be more prone to payments of merger bonuses, respectively. ${ }^{124}$ In addition, Capron and Shen (2007) examine the decision to acquire either a private or a public target from a strategic management perspective. In contrast to Baik et al. (2007), they predict and find evidence that bidders already incorporate differences in the information availability into their decisions to buy either private or public targets. Consistent with Capron and Shen (2007) and Pungaliya and Vijh (2009), we assume that acquirers in transactions with public targets exhibit potentially greater incentives and greater opportunities to engage in accruals manipulation due to higher valuation uncertainty, higher degree of dispersed ownership and potentially weaker ties between managers and owners in public targets than acquirers in transactions with private and / or subsidiary targets. Untabulated results of an extended analysis (with public, private, and subsidiary targets) underline our assumption. ${ }^{125}$ Although we find significant evidence for earnings management and for a promoting role of corporate governance in the period(s) prior to the transaction over all three samples - (1) with public targets, (2) with public and private targets, as well as (3) with public, private and subsidiary targets - the strength of the results is decreasing when considering non-listed targets.

\footnotetext{
${ }^{123}$ See Appendix 5 - 6.

124 Other earnings management studies, however, do not address explicitly the different target public statuses. Botsari and Meeks (2008), for example, allow implicitly for different target public statuses in their sample selection process but do not report results separately, whereas Erickson and Wang (1999) only consider public targets in their analyses.

${ }^{125}$ See Appendix 5 - 7 to Appendix 5 - 8.
} 


\section{Discretionary Accruals}

Fifth, we use alternative discretionary accrual proxies to assess the sensitivity of our discretionary accrual model choice. With respect to the original model described in section 5.4.3, we employ discretionary accruals from a cross-sectional modified Jones model (CMJM) (1) with CFO and growth adjustments but based on total accruals (TAC), (2) with only CFO adjustments and based on total accruals (TAC), (3) with ROA and growth matched ${ }^{126}$ discretionary accruals based on CMJM with CFO adjustments and total accruals (TAC), (4) with only CFO adjustments but based on current accruals (CAC), and (5) with ROA and growth matched discretionary accruals based on CMJM with CFO adjustments and current accruals (CAC). Untabulated results based on the five alternative discretionary accrual proxies confirm our original findings. Specifically, we find significant evidence for incomeincreasing accruals manipulation in the first period prior to the deal (TRANS-1) across all five discretionary accrual proxies. In addition, our results suggesting a promoting role of corporate governance on accruals manipulation prior to share deals are likewise unaffected by changes in the discretionary accrual model. ${ }^{127}$

\section{Corporate Governance Measure}

Sixth, we vary in the governance proxy construction to assess the sensitivity of our approach described in section 5.4.4. First, in order to extend the self-constructed governance score $\left(G_{\text {ISS }}\right)$ over the M\&A sample period, we alternatively take the median $\mathrm{GOV}_{\text {ISS }}$ value per firm. Second, we employ a dummy variable indicating strong (with 1) and poor (with 0) governance quality based on the governance scores ( $\mathrm{GOV}_{\text {ISS }}$ ) of all UK rated firms. Third, we employ a dummy variable indicating with one if the acquirer's governance measure (GOV) belongs to the $10^{\text {th }}$ deciles, and zero otherwise. Fourth, using the ISS raw data as well, we alternatively base the final governance proxy on a Principal Component Analysis. In particular, we use the averaged principal component with the highest eigenvalue - estimated on the six self-constructed sub-scores board, audit, charter \& bylaws, compensation,

\footnotetext{
${ }^{126}$ Alternatively to our initial approach to control for growth in the estimation process of discretionary accruals, we apply - following Collins et al. (2012), Roychowdhury (2006), and Garcia Lara et al. (2012) - a performance matching technique based on ROA and sales growth. We estimate performance- and growth-matched discretionary accruals for each acquirer by adjusting the respective estimated discretionary accruals from the extended cross-sectional modified Jones model by those of a matching control firm. For each acquirer, we select the matching control firm that has the closest sales growth figure based on the same fiscal year, the same twodigit SIC industry group, and the same $\mathrm{ROA}_{\mathrm{t}-1}$ quintile.

${ }^{127}$ See Appendix 5 - 9 to Appendix 5 - 10.
} 
progressive practice, and ownership (RiskMetrics, 2007). Finally, we split our original GOV measure to aggregate those subcategories which comprise either monitoring or incentive provisions.

Untabulated results based on the different governance proxies confirm our original findings. In particular, we find significant evidence across all different governance proxies that acquirers with strong governance engage more aggressively in income-increasing accruals manipulation in the period(s) preceding the deal announcement than their counterparts with weak governance. Moreover, splitting the original GOV measure into monitoring and incentive measures suggest that especially incentive provisions (compensation and managerial ownership provisions) promote accruals manipulation prior to the deal announcement. In line with our hypothesis, the latter finding is particularly consistent with the notion that existing shareholders of the acquiring firm incentivize management for short-term stock performance and accruals manipulation prior to share deals. ${ }^{128}$

To address the stickiness of firm-level governance in our setting, we perform governance-performance (Tobin's Q) regressions over (a) all firm-year observations for which individual UK governance scores (GOV $\mathrm{GIS}_{\text {) }}$ ) are available (with years between 2003 and 2007) and (b) over the whole sample period (with years between 1998 and 2011) with averaged governance scores (GOV). In addition, we split the samples for (i) acquirer's and (ii) non-acquirer's firm-year observations. We conjecture that high (low) governance stickiness leads to relatively similar (substantially different) results of GOV and $\mathrm{GOV}_{\text {ISS }}$ across the different regression specifications. In favor of sticky firm-level governance, untabulated results reveal that in most regression specifications, the sign and the significance levels of GOV and GOV ISS are similar. ${ }^{129}$

\section{Additional Control Variables}

Seventh, we assess the sensitivity of our control variable choice. To that end, we employ additional M\&A as well as firm control variables in our original regression analysis (Table 5 6) and apply a statistical procedure (stepwise regressions) to select our independent variables. The stepwise regression technique is executed in two different versions (forward stepwise and backward stepwise) to select the independent variables pursuant pre-specified significance

\footnotetext{
${ }^{128}$ See Appendix 5 - 11 .

${ }^{129}$ See Appendix 5 - 12.
} 
levels for removal $(\mathrm{pr}=0.15)$ and for addition $(\mathrm{pe}=0.10)$. In the absence of prior research providing profound theoretical links between M\&A related incentives and earnings management, we use a broad range of variables on a rather exploratory base. ${ }^{130}$ In particular, as additional M\&A control variables, we consider whether the target is a non-UK firm (crossborder deals), whether the deal is completed, whether majority voting rights are transferred, whether the acquirers are serial bidders (M\&A activity), whether the deal announcement is strategically timed, whether the deal is structured as a tender offer, whether the transactions take place in M\&A waves, and the duration of deal negotiation. As additional firm control variables, we consider acquirer's book-to-market of equity, cash from operations, fees paid for auditing, analyst recommendations, analyst coverage, and IFRS reporting.

Untabulated results reveal that our positive and significant governance and discretionary accruals results even hold after the inclusion of all (additional) control variables and remain unaffected by the statistical selection of control variables via stepwise regressions. In addition, acquirers' size and leverage as well as the relative deal size are consistently related to accruals manipulation across the models. Moreover, we find weak evidence for a constraining role of analyst coverage on earnings management in the period prior to the deal announcement. $^{131}$

\subsection{Conclusion}

Using stock swap transactions with public acquirers originating from the UK between the years 1998 and 2011, we find that acquirers with strong corporate governance engage more aggressively in income-increasing accruals manipulation than those with weak governance prior to the stock swap announcement. This finding is robust to different discretionary accrual models, to M\&A control variables, to a control group of $100 \%$ cash acquirers, to potential sample selection problems, and is further consistent with the notion that corporate governance incentivizes managerial actions in the interests of firms' shareholders. In addition, analyses of acquirers' long term buy-and-hold abnormal returns (BHARs) surrounding the deal announcement support our earnings management and governance findings.

This paper makes several contributions to the literature. As to our knowledge this is the first paper to shed light on the role of corporate governance in shaping earnings management

${ }^{130}$ Prior literature examining determinants on share price performance around M\&A transactions provides insights into potential determinants of accruals manipulation (e.g., Amar et al., 2011, pp. 484-485).

${ }^{131}$ See Appendix 5 - 13. 
in a setting in which prior literature has demonstrated to be characterized by incomeincreasing accruals manipulation. More importantly, we exploit a setting in which we expect to find a promoting role of corporate governance on earnings management. To that end, we contribute to prior research on the relationship between governance and earnings management by highlighting the setting-specific nature of this relationship. Second, we extend research on earnings management prior to stock swap transactions by assessing the acquirer's governance quality and by considering growth adjustments in the estimation process of discretionary accruals. Overall, our findings are important as they shed light on the endogenous nature of accruals quality as well as on the role of corporate governance with its respective beneficial or detrimental outcomes for shareholders and other stakeholders.

Our findings are subject to several limitations. As most earnings management studies, we employ the Worldscope's standardized financial statement data to estimate discretionary accruals. As Young (2008, p. 674) notes, this might induce an estimation bias since the financial data underlying our accrual models contains both, the adjustments made by Worldscope analysts as well as accounting choices made by management. Even though we challenge the findings with different discretionary accrual proxies and incorporate growth adjustments in the initial proxy (Collins et al., 2012), the robustness of the findings depends substantially on the perceived specification power of our discretionary accrual models. Owing to our specific research question, we do not address other forms of earnings management (e.g., real earnings management) which might become more important over time as substitutes of accrual-based earnings management (e.g., Roychowdhury, 2006).

Therefore, our findings create various research opportunities. Future work may address the M\&A-related determinants of accruals manipulation in more detail in order to gain a more comprehensive understanding of the underlying economic incentives of earnings management prior to stock swap transactions. Extending our study, future work may also examine other types of earnings management and their interrelations with governance quality prior to stock swap deals. Moreover, future research may challenge our study by comparing the UK findings with those from different institutional settings. It is reasonable to assume that the role of corporate governance varies across different corporate governance systems (continental Europe vs. Anglo-Saxon), and the respective governance perceptions (shareholder vs. stakeholder orientation). 


\subsection{Appendix}

\section{Appendix 5 - 1: BHARs surrounding the Deal Announcement}

\begin{tabular}{ccccccc}
\hline Panel A. Mean / Median BHARs around Stock Swaps: all GOV rated stock swaps & & \\
\hline Time / Var & Mean & Median & SD & Min. & Max. & N \\
\hline TRANS-2 & 0.2886 & 0.0487 & 1.9131 & -1.6412 & 12.5981 & 47 \\
TRANS-1 & $\mathbf{0 . 1 2 1 1 *}_{\text {TRANS0 }}$ & $\mathbf{0 . 1 2 5 5 ^ { * * }}$ & $\mathbf{0 . 6 7 1 7}$ & $\mathbf{- 2 . 2 6 7 8}$ & $\mathbf{2 . 0 6 9 7}$ & $\mathbf{5 4}$ \\
TRANS+1 & 0.0226 & -0.0342 & 0.5447 & -1.2123 & 1.7429 & 61 \\
TRANS+2 & $\mathbf{- 0 . 1 2 6 9 *}$ & $\mathbf{- 0 . 0 8 5 0 ^ { * }}$ & $\mathbf{0 . 6 2 5 7}$ & $\mathbf{- 1 . 3 2 8 3}$ & $\mathbf{1 . 3 8 7 4}$ & $\mathbf{6 3}$ \\
\hline
\end{tabular}

Panel B. Mean / Median BHARs around Stock Swaps: above mean GOV rated stock swaps

\begin{tabular}{ccccccc}
\hline Time $/$ Var & Mean & Median & SD & Min. & Max. \\
\hline TRANS-2 & $0.1251^{*}$ & 0.0983 & 0.4158 & -0.8868 & 0.9340 & $\mathbf{2}$ \\
TRANS-1 & $\mathbf{0 . 2 4 1 3 * *}$ & $\mathbf{0 . 2 3 2 4 * *}$ & $\mathbf{0 . 5 5 4 7}$ & $\mathbf{- 0 . 7 3 5 3}$ & $\mathbf{2 . 0 6 9 7}$ \\
TRANS0 & 0.0310 & 0.0319 & 0.4204 & -0.7482 & 1.0552 \\
TRANS+1 & $\mathbf{- 0 . 1 1 6 8}$ & $\mathbf{- 0 . 1 0 6 8}$ & $\mathbf{0 . 6 3 7 9}$ & $\mathbf{- 1 . 3 1 1 4}$ & $\mathbf{1 . 3 8 7 4}$ \\
TRANS+2 & -0.0489 & -0.0576 & 0.4642 & -1.1947 & 0.8971 & 30 \\
\hline
\end{tabular}

Panel C. Mean / Median BHARs around Stock Swaps: below mean GOV rated stock swaps

\begin{tabular}{ccccccc}
\hline Time $/$ Var & Mean & Median & SD & Min. & Max. & N \\
\hline TRANS-2 & 0.4591 & -0.1010 & 2.7226 & -1.6412 & 12.5981 & $\mathbf{2 . 0 4 7 4}$ \\
TRANS-1 & $\mathbf{0 . 0 1 7 4}$ & $\mathbf{0 . 0 1 2 2}$ & $\mathbf{0 . 7 5 2 4}$ & $\mathbf{- 2 . 2 6 7 8}$ & $\mathbf{2 9}$ \\
TRANS0 & 0.0145 & -0.1334 & 0.6500 & -1.2123 & 1.7429 \\
TRANS+1 & $\mathbf{- 0 . 1 3 6 7}$ & $\mathbf{- 0 . 0 6 6 3}$ & $\mathbf{0 . 6 2 3 7}$ & $\mathbf{- 1 . 3 2 8 3}$ & $\mathbf{1 . 0 9 7 8}$ \\
TRANS+2 & -0.0902 & $-0.1895^{*}$ & 0.4465 & -0.7861 & 1.1721 & 31 \\
\hline
\end{tabular}

Panel D: BHARs relative to the Deal Announcement Month: all GOV rated stock swaps

\begin{tabular}{|c|c|c|c|c|c|c|c|}
\hline $\begin{array}{l}\text { Months relative to deal } \\
\text { announcement month }\end{array}$ & $\begin{array}{c}\text { Average raw } \\
\text { buy-and-hold } \\
\text { returns }(\%)\end{array}$ & $\begin{array}{c}\text { Average buy-and- } \\
\text { hold abnormal } \\
\text { returns (BHAR) (\%) }\end{array}$ & $\mathbf{N}$ & $\begin{array}{l}\text { Av. BHAR of } \\
\text { EM Quartiles } \\
\text { Q1 \& Q2 (\%) }\end{array}$ & $\mathbf{N}$ & $\begin{array}{l}\text { Av. BHAR of } \\
\text { EM Quartiles } \\
\text { Q3 \& Q4 (\%) }\end{array}$ & $\mathbf{N}$ \\
\hline-36 to -1 & $222.56 * * *$ & $63.56 * * *$ & 44 & $40.91 *$ & 23 & $88.35 * *$ & 21 \\
\hline-24 to -1 & $188.47 * * *$ & $32.88 * *$ & 53 & 11.80 & 28 & $56.49 * *$ & 25 \\
\hline-12 to -1 & $141.63 * * *$ & $20.53 *$ & 58 & 8.37 & 30 & 33.56 & 28 \\
\hline-6 to -1 & $119.70 * * *$ & 6.75 & 62 & 3.90 & 30 & 12.69 & 30 \\
\hline+1 to +6 & 100.48 & -1.82 & 64 & 0.51 & 30 & -4.42 & 31 \\
\hline+1 to +12 & $110.23 *$ & -1.21 & 64 & -11.36 & 30 & 6.77 & 31 \\
\hline+1 to +24 & 111.80 & -11.79 & 59 & -24.16 & 29 & -9.81 & 27 \\
\hline+1 to +36 & $79.31 * *$ & $-27.84 * *$ & 55 & $-42.13 * * *$ & 27 & -13.04 & 25 \\
\hline \multicolumn{2}{|c|}{ Mean GOV in \% (in TRANS-1) } & 45.38 & 62 & 42.75 & 31 & 48.02 & 31 \\
\hline \multicolumn{2}{|c|}{ Mean DAC in \% (in TRANS- 1 ) } & 2.84 & 62 & -1.56 & 31 & 7.25 & 31 \\
\hline
\end{tabular}

Notes: We follow the approach proposed by Barber and Lyon (1997, pp. 344, 355) and estimate the BHARs as follows:

BHAR $_{i T}=\prod_{t=1}^{T}\left[1+R_{i t}\right]-\prod_{t=1}^{T}\left[1+E\left(R_{i t}\right)\right]$.

$\mathrm{BHAR}_{\mathrm{iT}}$ is the buy-and-hold abnormal return of firm $\mathrm{i}$ over a period of $\mathrm{T}$ months. $\mathrm{R}_{\mathrm{it}}-$ as the firm's simple return (Barber and Lyon 1997, p. 349) - is defined as the change in stock prices plus dividends divided by last year's stock price. $\mathrm{E}\left(\mathrm{R}_{\mathrm{it}}\right)$ is the expected return of firm $\mathrm{i}$ at month t measured as the simple return of a control firm at month t. Following Barber and Lyon (1997, p. 355), we choose the control firms as follows: (1) we identify all non-stock acquirers with a market value of equity between $70 \%$ and $130 \%$ of the market value of equity of each acquirer (yearly-based); (2) from the acquirer's individual matching portfolio, we select the nonstock acquirer with the book-to-market ratio closest to that of the acquirer.

Notes [Panel A-C]: These panels present distribution characteristics of acquirer's buy-and-hold abnormal returns (BHARs) in the periods surrounding the stock swap announcement (for different samples). TRANS indicates the different periods (years) prior to and after the stock swap announcement. TRANS-1 (TRANS-2) presents the acquirer's first (second) year with an earnings release preceding the stock swap announcement, whereas TRANS0 (TRANS+1) presents the year with the acquirer's first (second) earnings release following the stock swap announcement. The significance tests are based on t-test statistics (for mean values) and Wilcoxon signed-ranks test statistics (for median values). *** $(* *)(*)$ indicates significance levels at $1 \%(5 \%)(10 \%)$, onetailed.

Notes [Panel D]: This panel presents mean values of acquirer's raw buy-and-hold returns and buy-and-hold abnormal returns (BHARs) over different periods (months) relative to the respective deal announcement month of the stock swap transactions. Average BHARs of EM Quartiles Q1 \& Q2 (Q3 \& Q4) are mean values of the acquirer's buy-and-hold abnormal returns for a portfolio of acquirers with below median (above median) discretionary accruals based on TRANS-1. The significance tests are based on t-test statistics (for mean values) 
and Wilcoxon signed-ranks test statistics (for median values), whereas mean raw buy-and-hold returns (mean buy-and-hold abnormal returns) are tested against 100 (against 0 ). ${ }^{* * *}\left({ }^{* *}\right)\left({ }^{*}\right)$ indicates significance levels at $1 \%(5 \%)(10 \%)$, one-tailed. 
Appendix 5 - 2: Sample Selection - Cash Acquirer

Panel A. SDC Platinum - International Mergers (IMA): Start Parameter

- $\quad$ Date announced: 01/01/1998 to 31/12/2011

- Acquirer Nation: UK

- Acquirer Public Status: P (public)

- Target Public Status: P (public)

- Acquisition Technique: -

Panel B. Sample Selection

No. of deals

Initial Sample (with ISIN available)

Financial acquirer

Non-100\%-Cash Acquirer

No M\&A Deal

Duplicate acquisitions (first deal remains in sample)

Datastream / Worldscope data unavailable

Governance data unavailable Final Sample

\begin{tabular}{ll}
-180 & 750 \\
-344 & 570 \\
-54 & 226 \\
-45 & 172 \\
-25 & 127 \\
-38 & 102 \\
& 64 \\
\hline
\end{tabular}

Panel C. Sample Distribution

\begin{tabular}{|c|c|c|c|c|c|c|c|}
\hline Years & 1998 & 1999 & 2000 & 2001 & 2002 & 2003 & 2004 \\
\hline No. of Transactions & 7 & 12 & 9 & 4 & 4 & 1 & 5 \\
\hline Years & 2005 & 2006 & 2007 & 2008 & 2009 & 2010 & 2011 \\
\hline No. of Transactions & 2 & 13 & 2 & 1 & 1 & 2 & 1 \\
\hline
\end{tabular}

Appendix 5 - 3: Descriptive Analyses - Cash Acquirer

Panel A. Descriptive Analysis

\begin{tabular}{|c|c|c|c|c|c|c|}
\hline Descriptive values (TRANSO) & Sample Size $=64$ & Mean & Median & St.Dev. & Min. & Max. \\
\hline \multicolumn{7}{|l|}{ EARNINGS MANAGEMENT \& GOVERNANCE } \\
\hline Acquirer's Discretionary Accruals - $(D A C)$ & & 2.14 & 0.31 & 16.64 & -43.52 & 42.63 \\
\hline Acquirer's Governance Quality - (GOV) & & 49.93 & 50.75 & 23.33 & 4.35 & 94.41 \\
\hline \multicolumn{7}{|l|}{ FIRM CONTROLS } \\
\hline Acquirer's Total Assets (in $€$ Mill.) & & 9,666 & 1,806 & 33,900 & 31.56 & 265,000 \\
\hline Acquirer's Market Value (in $€$ Mill.) & & 9,612 & 1,767 & 27,189 & 53,51 & 200,110 \\
\hline Acquirer's Leverage $(L E V)$ & & .2189 & .2043 & .1293 & 0 & .5253 \\
\hline Acquirer's Ownership (OWNER) & & 15.21 & 11.78 & 17.89 & 0.02 & 85.04 \\
\hline Acquirer's Audit (BIG_FIVE) & & 1 & 1 & 0 & 1 & 1 \\
\hline \multicolumn{7}{|l|}{ M\&A CONTROLS } \\
\hline Deal-Value (in $€$ Mill.) & & 635.77 & 101.06 & 3,167 & 0.29 & 31,005 \\
\hline Relative Deal Value (Rel. Deal Size, \%) & & 31.79 & 17.83 & 51.99 & 0 & 439.48 \\
\hline Industrial Relatedness (Ind_Relatedness) & & .3846 & 0 & .4903 & 0 & 1 \\
\hline Percentage of Stock (Stock) & & 0 & 0 & 0 & 0 & 0 \\
\hline
\end{tabular}

Panel B. Mean / Median DAC around Stock Swaps: all GOV rated cash transactions

\begin{tabular}{ccccccc}
\hline Time $/$ Var & Mean & Median & SD & Min. & Max. & N \\
\hline TRANS-2 & -0.0011 & 0.0000 & 0.0550 & -0.1367 & 0.1722 & 62 \\
TRANS-1 & $\mathbf{0 . 0 0 5 0}$ & $\mathbf{0 . 0 0 0 0}$ & $\mathbf{0 . 0 7 6 4}$ & $\mathbf{- 0 . 3 4 0 6}$ & $\mathbf{0 . 1 4 7 1}$ & $\mathbf{6 3}$ \\
TRANS0 & 0.0214 & 0.0032 & 0.1664 & -0.4353 & 0.4263 \\
TRANS+1 & $\mathbf{0 . 0 1 0 8}$ & $\mathbf{0 . 0 0 0 2}$ & $\mathbf{0 . 0 8 3 9}$ & $\mathbf{- 0 . 2 0 7 1}$ & $\mathbf{0 . 2 4 8 9}$ & 64 \\
TRANS+2 & 0.0067 & $0.0000^{*}$ & 0.0965 & -0.5130 & 0.1868 & $\mathbf{6 0}$ \\
\hline
\end{tabular}

Notes: For detailed information and definitions of the variables, see Appendix 5 - 14. The significance tests are based on t-test statistics (for the mean values) and Wilcoxon signed-ranks test statistics (for the median values). $* * *(* *)(*)$ indicates significance levels at $1 \%(5 \%)(10 \%)$, one-tailed. 
Appendix 5 - 4: Governance Role - Cash Acquirer

\begin{tabular}{|c|c|c|c|c|c|c|}
\hline \multirow{3}{*}{ Variables } & \multicolumn{6}{|c|}{ Dependent variable: Discretionary Accruals (CMJM with CFO \& Growth adj./ CAC) } \\
\hline & \multicolumn{3}{|c|}{ Periods prior to the Stock Swap Transaction } & \multicolumn{3}{|c|}{ Periods after the Stock Swap Transaction } \\
\hline & $\begin{array}{l}\text { TRANS-1 } \\
\text { Model } 1\end{array}$ & $\begin{array}{c}\text { TRANS-1/-2 } \\
\text { Model } 2\end{array}$ & $\begin{array}{c}\text { TRANS-1/-3 } \\
\text { Model } 3\end{array}$ & $\begin{array}{c}\text { TRANS+1 } \\
\text { Model } 4\end{array}$ & $\begin{array}{l}\text { TRANS }+\mathbf{1} /+\mathbf{2} \\
\text { Model } 5\end{array}$ & $\begin{array}{l}\text { TRANS }+\mathbf{1} /+\mathbf{3} \\
\text { Model } 6\end{array}$ \\
\hline Intercept & $\begin{array}{l}.0692 \\
(1.05)\end{array}$ & $\begin{array}{l}-.0154 \\
(-0.37)\end{array}$ & $\begin{array}{l}-.0106 \\
(-0.47)\end{array}$ & $\begin{array}{l}.1538 \\
(0.93)\end{array}$ & $\begin{array}{l}-.0046 \\
(-0.03)\end{array}$ & $\begin{array}{l}-.0725 \\
(-0.52)\end{array}$ \\
\hline GOV & $\begin{array}{l}.0786 * \\
(1.77)\end{array}$ & $\begin{array}{l}.0138 \\
(0.36)\end{array}$ & $\begin{array}{l}.0202 \\
(0.62)\end{array}$ & $\begin{array}{c}.0979 * * \\
(2.23)\end{array}$ & $\begin{array}{l}.0622 \\
(1.09)\end{array}$ & $\begin{array}{l}.0597 \\
(1.17)\end{array}$ \\
\hline DEAL SIZE & $\begin{array}{l}.0000 \\
(0.48)\end{array}$ & $\begin{array}{l}.0000 \\
(0.69)\end{array}$ & $\begin{array}{l}.0000 \\
(0.04)\end{array}$ & $\begin{array}{l}-.0001 \\
(-1.35)\end{array}$ & $\begin{array}{l}-.0000 \\
(-0.47)\end{array}$ & $\begin{array}{l}.0000 \\
(0.17)\end{array}$ \\
\hline $\begin{array}{l}\text { IND RELATEDNESS } \\
\text { STOCK }\end{array}$ & $\begin{array}{c}-.0129 \\
(-0.72) \\
\text { (omitted) }\end{array}$ & $\begin{array}{c}-.0046 \\
(-0.38) \\
\text { (omitted) }\end{array}$ & $\begin{array}{c}-.0048 \\
(-0.42) \\
\text { (omitted) }\end{array}$ & $\begin{array}{c}.0263 \\
(1.37) \\
\text { (omitted) }\end{array}$ & $\begin{array}{c}.0221 \\
(1.17) \\
\text { (omitted) }\end{array}$ & $\begin{array}{c}.0183 \\
(1.63) \\
\text { (omitted) }\end{array}$ \\
\hline BIG FIVE & (omitted) & (omitted) & (omitted) & (omitted) & (omitted) & (omitted) \\
\hline OWNER & $\begin{array}{l}-.0057 \\
(-0.99)\end{array}$ & $\begin{array}{l}.0004 \\
(0.10)\end{array}$ & $\begin{array}{l}.0009 \\
(0.28)\end{array}$ & $\begin{array}{l}.0026 \\
(0.88)\end{array}$ & $\begin{array}{l}.0043 \\
(1.39)\end{array}$ & $\begin{array}{l}.0031 \\
(0.93)\end{array}$ \\
\hline SIZE & $\begin{array}{l}-.0072 \\
(-1.59)\end{array}$ & $\begin{array}{l}.0006 \\
(0.16)\end{array}$ & $\begin{array}{l}.0001 \\
(0.02)\end{array}$ & $\begin{array}{l}-.0141 \\
(-1.26)\end{array}$ & $\begin{array}{l}-.0026 \\
(-0.28)\end{array}$ & $\begin{array}{l}.0028 \\
(0.34)\end{array}$ \\
\hline LEV & $\begin{array}{c}.0553 \\
(0.96)\end{array}$ & $\begin{array}{l}.0127 \\
(0.34) \\
\end{array}$ & $\begin{array}{l}.0355 \\
(0.86) \\
\end{array}$ & $\begin{array}{l}.0194 \\
(0.28)\end{array}$ & $\begin{array}{l}.0270 \\
(0.54)\end{array}$ & $\begin{array}{l}-.0231 \\
(-0.58)\end{array}$ \\
\hline $\begin{array}{l}\text { Clustered se (1w) } \\
\text { Clustered se (2w) }\end{array}$ & $\begin{array}{l}\text { Yes } \\
\text { No }\end{array}$ & $\begin{array}{l}\text { No } \\
\text { Yes }\end{array}$ & $\begin{array}{l}\text { No } \\
\text { Yes }\end{array}$ & $\begin{array}{l}\text { Yes } \\
\text { No }\end{array}$ & $\begin{array}{l}\text { No } \\
\text { Yes }\end{array}$ & $\begin{array}{l}\text { No } \\
\text { Yes }\end{array}$ \\
\hline Adj. $R^{2}$ & -.0093 & -.0443 & -0.0218 & -0.0262 & -0.0226 & -0.0017 \\
\hline Sample Size & 63 & 125 & 183 & 60 & 116 & 167 \\
\hline
\end{tabular}

Notes: The underlying regression model is:

DAC $_{i t}=\alpha+\gamma_{1}$ GOV $_{\text {it }}+\sum \gamma_{2}$ M\&A_CONTROL $_{i t}+\sum \gamma_{3}$ FIRM_CONTROL $_{i t}+\varepsilon$

Where $\alpha$ represents the constant term, $\gamma_{1}-\sum \gamma_{3}$ are the coefficients of the explanatory variables, and $\varepsilon$ is the error term. The dependent variable DAC represents discretionary accruals obtained from an extended (by CFO and growth adjustments) cross-sectional modified Jones model and measures accrual-based earnings management. GOV proxies firm-level governance quality. M\&A_CONTROL represents a vector of M\&A characteristics (relative deal size, industrial relatedness, and percentage of stock financing). FIRM_CONTROL represents a vector of firm characteristics (size, leverage, ownership concentration, and big five auditor). For detailed information and definitions of the variables, see Appendix 5 - 14. The regression models have standard errors which are heteroskedasticity robust and - as indicated - one-way clustered at year level or two-way clustered at firm and year level. Reported values: coefficient (t-value) *** (**) $\left(^{*}\right)$ indicates significance levels at $1 \%(5 \%)(10 \%)$, two-tailed. 
Appendix 5 - 5: BHARs surrounding the Deal Announcement - Cash Acquirer

Panel A. Mean / Median BHARs around Cash Transactions: all GOV rated deals

\begin{tabular}{ccccccc}
\hline Time $/$ Var & Mean & Median & SD & Min. & Max. & N \\
\hline TRANS-2 & 0.1152 & 0.0658 & 0.6599 & -1.7063 & $\mathbf{- 2 . 2 2 5 7}$ & $\mathbf{1 . 1 2 5 3}$ \\
TRANS-1 & $\mathbf{- 0 . 0 6 7 0}$ & $\mathbf{- 0 . 0 0 7 3}$ & $\mathbf{0 . 5 1 4 4}$ & -1.1249 & 1.0798 \\
TRANS0 & 0.0723 & 0.0544 & 0.4661 & $\mathbf{5 6}$ & 59 \\
TRANS+1 & $\mathbf{- 0 . 0 8 2 7}$ & $\mathbf{- 0 . 0 0 9 0}$ & $\mathbf{0 . 5 5 8 3}$ & $\mathbf{- 2 . 8 9 4 1}$ & $\mathbf{0 . 9 0 7 7}$ \\
TRANS+2 & 0.0468 & 0.0430 & 0.4447 & -0.9558 & 0.8980 \\
\hline
\end{tabular}

Panel B. Mean / Median BHARs around Cash Transactions: all above mean GOV rated deals

\begin{tabular}{|c|c|c|c|c|c|c|}
\hline Time / Var & Mean & Median & SD & Min. & Max. & $\mathbf{N}$ \\
\hline TRANS-2 & 0.0667 & 0.0162 & 0.7129 & -1.7063 & 2.9992 & 33 \\
\hline TRANS-1 & -0.0299 & -0.0073 & 0.4741 & -1.7936 & 1.1253 & 34 \\
\hline TRANS0 & 0.0699 & 0.0843 & 0.4922 & -1.1249 & 0.9323 & 36 \\
\hline TRANS+1 & $-0.2196^{* *}$ & $-0.1634 *$ & 0.6332 & -2.8941 & 0.5451 & 34 \\
\hline TRANS +2 & 0.0973 & 0.1487 & 0.4984 & -0.9558 & 0.8980 & 32 \\
\hline \multicolumn{7}{|c|}{ Panel C. Mean / Median BHARs around Cash Transactions: all below mean GOV rated deals } \\
\hline Time / Var & Mean & Median & SD & Min. & Max. & $\mathbf{N}$ \\
\hline TRANS-2 & $0.1914^{*}$ & 0.2449 & 0.5751 & -0.8864 & 1.6288 & 21 \\
\hline TRANS-1 & -0.1243 & -0.0291 & 0.5780 & -2.2257 & 0.5220 & 22 \\
\hline TRANS0 & 0.0760 & -0.0165 & 0.4328 & -0.8517 & 1.0798 & 23 \\
\hline TRANS+1 & $0.1197 *$ & 0.1234 & 0.3468 & -0.3565 & 0.9077 & 23 \\
\hline TRANS +2 & -0.0267 & 0.0335 & 0.3505 & -0.9130 & 0.4974 & 22 \\
\hline
\end{tabular}

Panel D: BHARs relative to the Deal Announcement Month: all GOV rated cash transactions

\begin{tabular}{|c|c|c|c|c|c|c|c|}
\hline $\begin{array}{l}\text { Months relative to deal } \\
\text { announcement month }\end{array}$ & $\begin{array}{c}\text { Average raw } \\
\text { buy-and-hold } \\
\text { returns }(\%)\end{array}$ & $\begin{array}{c}\text { Average buy-and- } \\
\text { hold abnormal } \\
\text { returns (BHAR) }(\%)\end{array}$ & $\mathbf{N}$ & $\begin{array}{l}\text { Av. BHAR of } \\
\text { EM Quartiles } \\
\text { Q1 \& Q2 }(\%)\end{array}$ & $\mathbf{N}$ & $\begin{array}{l}\text { Av. BHAR of } \\
\text { EM Quartiles } \\
\text { Q3 \& Q4 (\%) }\end{array}$ & $\mathbf{N}$ \\
\hline-36 to -1 & $163.66^{* * *}$ & 11.19 & 52 & $29.45^{*}$ & 26 & -7.24 & 25 \\
\hline-24 to -1 & $132.15 * * *$ & 8.86 & 56 & $19.48^{*}$ & 27 & -2.01 & 28 \\
\hline-12 to -1 & $138.30 * *$ & 6.28 & 59 & $22.07 *$ & 30 & -12.18 & 28 \\
\hline-6 to -1 & $114.15^{* *}$ & -7.68 & 61 & -10.71 & 30 & -7.78 & 29 \\
\hline+1 to +6 & $104.65 *$ & 1.00 & 60 & 1.20 & 31 & 2.74 & 28 \\
\hline+1 to +12 & 101.28 & -6.00 & 57 & -2.94 & 30 & -8.43 & 26 \\
\hline+1 to +24 & 102.52 & -10.86 & 54 & -6.97 & 28 & -17.08 & 25 \\
\hline+1 to +36 & $83.31 * *$ & -11.64 & 49 & -10.39 & 27 & -13.18 & 22 \\
\hline Mean GOV in \% (in TRANS-1) & & 48.95 & 61 & 44.71 & 31 & 53.34 & 30 \\
\hline Mean DAC in \% (in TRANS- 1 ) & & 0.46 & 61 & -4.34 & 31 & 5.44 & 30 \\
\hline
\end{tabular}

Notes [Panel A-C]: These panels present distribution characteristics of acquirer's buy-and-hold abnormal returns (BHARs) in the periods surrounding the cash deal announcement (for different samples). TRANS indicates the different periods (years) prior to and after the cash deal announcement. TRANS-1 (TRANS-2) presents the acquirer's first (second) year with an earnings release preceding the cash deal announcement, whereas TRANS0 (TRANS+1) presents the year with the acquirer's first (second) earnings release following the cash deal announcement. The significance tests are based on t-test statistics (for mean values) and Wilcoxon signed-ranks test statistics (for median values). $* * *(* *)(*)$ indicates significance levels at $1 \%(5 \%)(10 \%)$, onetailed.

Notes [Panel D]: This panel presents mean values of acquirer's raw buy-and-hold returns and buy-and-hold abnormal returns (BHARs) over different periods (months) relative to the respective deal announcement month of the covered cash transactions. Average BHARs of EM Quartiles Q1 \& Q2 (Q3 \& Q4) are mean values of the acquirer's buy-and-hold abnormal returns for a portfolio of acquirers with below median (above median) discretionary accruals based on TRANS-1. The significance tests are based on t-test statistics (for the mean values) and Wilcoxon signed-ranks test statistics (for the median values), whereas mean raw buy-and-hold returns (mean buy-and-hold abnormal returns) are set against 100 (against 0$)$. *** $(* *)(*)$ indicates significance levels at $1 \%(5 \%)(10 \%)$, one-tailed. 
Appendix 5 - 6: Sample Selection Bias

\begin{tabular}{|c|c|c|c|c|c|c|}
\hline \multirow{4}{*}{ Variables } & \multicolumn{6}{|c|}{ Dependent variable: Discretionary Accruals (CMJM with CFO \& Growth adj./ CAC) } \\
\hline & \multicolumn{3}{|c|}{ Periods prior to the Stock Swap Transaction } & \multicolumn{3}{|c|}{ Periods after the Stock Swap Transaction } \\
\hline & TRANS-1 & TRANS-1/-2 & TRANS-1/-3 & TRANS+1 & TRANS+1/+2 & TRANS+1/+3 \\
\hline & Model 1 & Model 2 & Model 3 & Model 4 & Model 5 & Model 6 \\
\hline \multirow[t]{2}{*}{ Intercept } & .1019 & .3308 & .2283 & -.1330 & -.0619 & .0134 \\
\hline & $(0.31)$ & $(1.30)$ & $(1.15)$ & $(-0.76)$ & $(-0.61)$ & $(0.23)$ \\
\hline \multirow[t]{2}{*}{ GOV } & $.0862 * *$ & $.1202 * *$ & $.1101 * * *$ & -.0148 & .0159 & .0148 \\
\hline & $(2.44)$ & $(2.47)$ & (2.99) & $(-0.27)$ & $(0.25)$ & $(0.30)$ \\
\hline \multirow[t]{2}{*}{ MILLS } & .0416 & -.0269 & .0128 & .0091 & .0134 & -.0229 \\
\hline & $(0.44)$ & $(-0.33)$ & $(0.24)$ & $(0.18)$ & $(0.38)$ & $(-0.62)$ \\
\hline \multirow[t]{2}{*}{ DEAL SIZE } & $-.0001 * * *$ & -.0000 & -.0000 & -.0000 & $-.0000 * *$ & -.0000 \\
\hline & $(-5.20)$ & $(-0.53)$ & $(-1.02)$ & $(-0.04)$ & $(-2.09)$ & $(-0.39)$ \\
\hline \multirow[t]{2}{*}{ IND RELATEDNESS } & -.0097 & .0070 & .0086 & .0129 & .0296 & .0238 \\
\hline & $(-0.41)$ & $(0.35)$ & $(0.54)$ & $(0.32)$ & $(1.23)$ & $(1.14)$ \\
\hline \multirow[t]{2}{*}{ STOCK } & .0000 & .0000 & .0001 & .0000 & -.0001 & .0000 \\
\hline & $(0.22)$ & $(0.00)$ & $(0.30)$ & $(0.05)$ & $(-0.23)$ & $(0.10)$ \\
\hline \multirow[t]{2}{*}{ BIG FIVE } & -.0080 & $-.1896 * *$ & $-.1641 *$ & $.0357 * *$ & .0144 & .0369 \\
\hline & $(-0.06)$ & $(-2.20)$ & $(-1.77)$ & $(2.41)$ & $(0.59)$ & $(0.81)$ \\
\hline \multirow[t]{2}{*}{ OWNER } & $-.0053 * *$ & -.0019 & -.0028 & .0017 & -.0022 & -.0004 \\
\hline & $(-2.34)$ & $(-0.39)$ & $(-0.98)$ & $(0.48)$ & $(-0.51)$ & $(-0.12)$ \\
\hline \multirow[t]{2}{*}{ SIZE } & -.0103 & -.0139 & -.0096 & .0039 & .0007 & -.0058 \\
\hline & $(-0.73)$ & $(-1.10)$ & $(-1.05)$ & $(0.26)$ & $(0.10)$ & $(-1.22)$ \\
\hline \multirow[t]{2}{*}{ LEV } & $.1222 * *$ & .0679 & $.0811^{*}$ & $.0726^{*}$ & .0390 & .0351 \\
\hline & $(2.77)$ & $(0.92)$ & $(1.81)$ & $(1.76)$ & $(0.67)$ & $(0.90)$ \\
\hline Clustered se (1w) & Yes & No & No & Yes & No & No \\
\hline Clustered se (2w) & No & Yes & Yes & No & Yes & Yes \\
\hline Adj. $R^{2}$ & .0947 & .0866 & .1245 & -.1156 & -.0293 & -.0092 \\
\hline Sample Size & 66 & 128 & 186 & 67 & 130 & 188 \\
\hline
\end{tabular}

Notes: The first stage (Probit) regression model is:

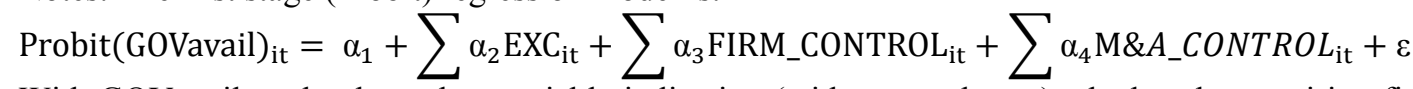

With GOVavail as the dependent variable indicating (with one and zero) whether the acquiring firm receives a GOV score or not (GOV score sample: $\mathrm{N}=70$, and whole stock swap sample: $\mathrm{N}=129$; for details on sample selection, see Table 5 - 2). EXCL represents the exclusion restriction (dividends per share; with a spearman correlation between dividends per share and GOVavail of 0.42 [p-value: 0.000]) in order to specify the first stage. For the remaining variables, see the information given below. For each model in the table above, I estimate the first stage based on the respective sample size with robust and two-way clustered standard errors at firm and year level.

The underlying regression model is:

DAC $_{\text {it }}=\alpha+\gamma_{1}$ GOV $_{i t}+\gamma_{2}$ MILLS $_{i t}+\sum \gamma_{3}$ M\&A_CONTROL $_{i t}+\sum \gamma_{4}$ FIRM_CONTROL $_{i t}+\varepsilon$

Where $\alpha$ represents the constant term, $\gamma_{1}-\sum \gamma_{4}$ are the coefficients of the explanatory variables, and $\varepsilon$ is the error term. The dependent variable DAC represents discretionary accruals obtained from an extended (CFO and growth adjusted) cross-sectional modified Jones model and measures accrual-based earnings management. GOV proxies firm-level governance quality. MILLS is the inverse mills ratio from the first stage (Probit) regression. M\&A_CONTROL represents a vector of M\&A characteristics (relative deal size, industrial relatedness, and percentage of stock financing). FIRM_CONTROL represents a vector of firm characteristics (size, leverage, ownership concentration, and big five auditor). For detailed information and definitions of the variables, see Appendix 5 - 14. The regression models have standard errors which are heteroskedasticity robust and - as indicated - one-way clustered at year level or two-way clustered at firm and year level. Reported values: coefficient (t-value) $* * *(* *)(*)$ indicates significance levels at 1\% (5\%) (10\%), two-tailed. 


\section{Appendix 5 - 7: Mean and Median DAC Analyses: Public Target Status}

Panel A. Mean / Median DAC: all GOV rated stock swaps with Public \& Private Targets

\begin{tabular}{ccccccc}
\hline Time $/$ Var & Mean & Median & SD & Min. & Max. & N \\
\hline TRANS-2 & 0.0096 & 0.0071 & 0.1194 & -0.5345 & 0.4307 & $\mathbf{- 0 . 2 2 7 8}$ \\
TRANS-1 & $\mathbf{0 . 0 2 1 5 * *}$ & $\mathbf{0 . 0 1 6 1 * *}$ & $\mathbf{0 . 0 9 1 7}$ & -0.5345 & 0.4307 \\
TRANS0 & 0.0016 & 0.0000 & 0.1805 & $\mathbf{0 . 4 3 0 7}$ & 87 \\
TRANS+1 & $\mathbf{- 0 . 0 1 6 1}$ & $\mathbf{0 . 0 0 0 0}$ & $\mathbf{0 . 1 1 8 8}$ & $\mathbf{- 0 . 5 3 4 5}$ & $\mathbf{0 . 1 7 2 0}$ & $\mathbf{8 5}$ \\
TRANS+2 & -0.0063 & 0.0001 & 0.0978 & -0.4644 & 0.2299 \\
\hline
\end{tabular}

Panel B. Mean / Median DAC: all GOV rated stock swaps with Public, Private \& Subsidiary Targets

\begin{tabular}{ccccccc}
\hline Time / Var & Mean & Median & SD & Min. & Max. \\
\hline TRANS-2 & 0.0085 & 0.0069 & 0.1163 & -0.5345 & 0.4307 & $\mathbf{N}$ \\
TRANS-1 & $\mathbf{0 . 0 1 5 0 *}$ & $\mathbf{0 . 0 1 3 5 *}$ & $\mathbf{0 . 0 9 4 0}$ & $\mathbf{- 0 . 2 2 7 8}$ & $\mathbf{0 . 4 3 0 7}$ \\
TRANS0 & 0.0021 & 0.0000 & 0.1756 & -0.5345 & 0.4307 \\
TRANS+1 & $\mathbf{- 0 . 0 1 5 5}$ & $\mathbf{0 . 0 0 0 0}$ & $\mathbf{0 . 1 1 9 4}$ & $\mathbf{- 0 . 5 3 4 5}$ & $\mathbf{0 . 1 7 2 0}$ \\
TRANS+2 & -0.0044 & 0.0004 & 0.0981 & -0.4644 & 0.2299 & 93 \\
\hline
\end{tabular}

Notes: This table presents distribution characteristics of acquirer's discretionary accruals in the periods around the stock swap announcement (for different samples). TRANS indicates the different periods (years) prior to and after the stock swap announcement. TRANS-1 (TRANS-2) presents the acquirer's first (second) year with an earnings release preceding the stock swap announcement, whereas TRANS0 (TRANS+1) presents the year with the acquirer's first (second) earnings release following the stock swap announcement. The significance tests are based on t-test statistics (for the mean values) and Wilcoxon signed-ranks test statistics (for the median values). $* * *(* *)(*)$ indicates significance levels at $1 \%(5 \%)(10 \%)$, two-tailed.

Appendix 5 - 8: Governance Role - Public Target Status

\begin{tabular}{|c|c|c|c|c|c|c|}
\hline \multirow{4}{*}{ Variables } & \multicolumn{6}{|c|}{ Dependent variable: Discretionary Accruals (CMJM with CFO \& Growth adj./ CAC) } \\
\hline & \multicolumn{3}{|c|}{ Public \& Private Targets } & \multicolumn{3}{|c|}{ Public \& Private \& Subsidiary Targets } \\
\hline & TRANS-1 & TRANS-1/-2 & TRANS-1/-3 & TRANS-1 & TRANS-1/-2 & TRANS-1/-3 \\
\hline & Model 1 & Model 2 & Model 3 & Model 4 & Model 5 & Model 6 \\
\hline \multirow[t]{2}{*}{ Intercept } & $.3199 * *$ & $.3030 * * *$ & $.2712 * * *$ & $.2830 * *$ & $.2816 * * *$ & $.2587 * * *$ \\
\hline & $(2.70)$ & $(3.82)$ & $(2.75)$ & $(2.38)$ & $(3.57)$ & $(2.75)$ \\
\hline \multirow[t]{2}{*}{ GOV } & $.1055 *$ & $.1222 * *$ & $.1018 * *$ & $.0864 * *$ & $.1069 * *$ & $.0923 * *$ \\
\hline & (2.13) & $(2.13)$ & $(2.29)$ & (2.29) & $(2.04)$ & $(2.16)$ \\
\hline \multirow[t]{2}{*}{ PUBLIC TARGET } & $.0466^{*}$ & .0198 & .0279 & $.0614 * * *$ & .0291 & $.0346 *$ \\
\hline & $(2.04)$ & $(0.94)$ & $(\mathbf{1 . 2 2})$ & (3.49) & (1.39) & $(\mathbf{1 . 6 8})$ \\
\hline \multirow[t]{2}{*}{ DEAL SIZE } & $-.0001 * * *$ & -.0000 & -.0000 & $-.0001 * * *$ & -.0000 & -.0000 \\
\hline & $(-3.04)$ & $(-1.00)$ & $(-0.65)$ & $(-3.15)$ & $(-0.79)$ & $(-0.56)$ \\
\hline \multirow[t]{2}{*}{ IND RELATEDNESS } & .0068 & .0175 & .0107 & -.0050 & .0062 & .0026 \\
\hline & $(0.24)$ & $(0.71)$ & $(0.61)$ & $(-0.18)$ & $(0.28)$ & $(0.15)$ \\
\hline \multirow[t]{2}{*}{ STOCK } & -.0004 & -.0005 & -.0002 & -.0002 & -.0004 & -.0002 \\
\hline & $(-1.13)$ & $(-1.32)$ & $(-0.64)$ & $(-0.71)$ & $(-1.13)$ & $(-0.59)$ \\
\hline \multirow[t]{2}{*}{ BIG FIVE } & -.0206 & $-.1569 * * *$ & $-.1711 * *$ & -.0280 & $-.1626^{* * *}$ & $-.1736^{* *}$ \\
\hline & $(-0.31)$ & $(-3.52)$ & $(-2.40)$ & $(-0.42)$ & $(-3.60)$ & $(-2.41)$ \\
\hline \multirow[t]{2}{*}{ OWNER } & $-.0070 * *$ & -.0030 & -.0024 & $-.0080 * *$ & -.0033 & -.0027 \\
\hline & $(-2.24)$ & $(-0.82)$ & $(-0.89)$ & $(-2.38)$ & $(-0.88)$ & $(-0.96)$ \\
\hline \multirow[t]{2}{*}{ SIZE } & $-.0253 * *$ & $-.0138 * *$ & $-.0117 * *$ & $-.0226^{* *}$ & $-.0117 * *$ & $-.0103 * *$ \\
\hline & $(-2.58)$ & $(-2.46)$ & $(-2.14)$ & $(-2.45)$ & $(-2.21)$ & $(-1.98)$ \\
\hline \multirow[t]{2}{*}{ LEV } & .0509 & .0501 & .0486 & .0543 & .0495 & .0423 \\
\hline & $(0.77)$ & $(0.79)$ & (1.16) & $(0.95)$ & $(0.83)$ & $(1.03)$ \\
\hline Clustered se (1w) & Yes & No & No & Yes & No & No \\
\hline Clustered se (2w) & No & Yes & Yes & No & Yes & Yes \\
\hline Adj. $\mathrm{R}^{2}$ & .0849 & .0811 & .1025 & .0888 & .0772 & .1044 \\
\hline Sample Size & 82 & 159 & 232 & 88 & 171 & 249 \\
\hline
\end{tabular}

Notes: The underlying regression model is:

DAC $_{i t}=\alpha+\gamma_{1}$ GOV $_{\text {it }}+\sum \gamma_{2}$ M\&A_CONTROL $_{i t}+\sum \gamma_{3}$ FIRM_CONTROL $_{i t}+\varepsilon$

Where $\alpha$ represents the constant term, $\gamma_{1}-\sum \gamma_{3}$ are the coefficients of the explanatory variables, and $\varepsilon$ is the error term. The dependent variable DAC represents discretionary accruals obtained from an extended (CFO and growth adjusted) cross-sectional modified Jones model and measures accrual-based earnings management. GOV proxies firm-level governance quality. M\&A_CONTROL represents a vector of M\&A characteristics (public target status, relative deal size, industrial relatedness, and percentage of stock financing). FIRM_CONTROL represents a vector of firm characteristics (size, leverage, ownership concentration, and big five auditor). For detailed information and definitions of the variables, see Appendix 5 - 14. The regression models have standard errors which are heteroskedasticity robust and - as indicated - one-way clustered at year level or two-way 
clustered at firm and year level. Reported values: coefficient (t-value) $* * *(* *)(*)$ indicates significance levels at $1 \%(5 \%)(10 \%)$, two-tailed. 
Appendix 5 - 9: Mean and Median DAC Analysis: Different DAC Measures

Sample: All GOV rated stock swaps (Sample Size =70)

\begin{tabular}{|c|c|c|c|c|c|c|c|c|c|c|}
\hline \multirow[t]{2}{*}{ Time / Var } & \multicolumn{2}{|c|}{$\begin{array}{c}\text { DAC }_{2} \\
\text { (CMJM with CFO } \\
\text { \&Growth adj./TAC) }\end{array}$} & \multicolumn{2}{|c|}{$\begin{array}{c}\text { DAC }_{3} \\
\text { (CMJM with CFO } \\
\text { adj. / TAC) } \\
\end{array}$} & \multicolumn{2}{|c|}{$\begin{array}{c}\text { DAC }_{4} \\
\text { (ROA \& Growth } \\
\left.\text { Matching on } \mathrm{DAC}_{3}\right)\end{array}$} & \multicolumn{2}{|c|}{$\begin{array}{c}\mathbf{D A C}_{\mathbf{5}} \\
\text { (CMJM with CFO } \\
\text { adj. / CAC) } \\
\end{array}$} & \multicolumn{2}{|c|}{$\begin{array}{c}\text { DAC }_{6} \\
\text { (ROA \& Growth } \\
\text { Matching on } \text { DAC }_{5} \text { ) }\end{array}$} \\
\hline & Mean & Median & Mean & Median & Mean & Median & Mean & Median & Mean & Median \\
\hline TRANS-2 & .016 & $.001 *$ & .009 & .003 & -.004 & -.001 & .012 & .009 & -.000 & .001 \\
\hline TRANS-1 & $.022 * * *$ & $.012 * *$ & $.024 * * *$ & $.012 * * *$ & $.026 * *$ & .009 & $.028 * * *$ & $.023 * * *$ & $.030 * *$ & .006 \\
\hline TRANS0 & -.005 & .006 & .001 & .008 & -.020 & -.011 & -.003 & .009 & $-.031 *$ & -.004 \\
\hline TRANS+1 & $-.015 *$ & .000 & -.016 & .000 & $-.030 * *$ & $-.013 * *$ & -.017 & -.002 & -.021 & .000 \\
\hline TRANS+2 & $-.016^{*}$ & .000 & -.011 & .002 & $-.022 *$ & -.004 & -.010 & .008 & -.021 & .006 \\
\hline
\end{tabular}

Notes: This table presents mean and median distributions of acquirer's discretionary accruals in the periods around the stock swap announcement (for different samples and for different DAC measures). TRANS indicates the different periods (years) prior to and after the stock swap announcement. TRANS-1 (TRANS-2) presents the acquirer's first (second) year with an earnings release preceding the stock swap announcement, whereas TRANS0 (TRANS+1) presents the year with the acquirer's first (second) earnings release following the stock swap announcement. DAC 2 (CMJM with CFO \& Growth adj. / TAC) stands for discretionary accruals (based on total accruals - TAC) from a cross-sectional modified Jones model with CFO and growth adjustments in the estimation process. $\mathrm{DAC}_{3}$ (CMJM with $\mathrm{CFO}$ adj. / TAC) stands for discretionary accruals (based on total accruals - TAC) from a cross-sectional modified Jones model with only CFO adjustments in the estimation process. $\mathrm{DAC}_{4}$ stands for performance and growth matched discretionary accruals from a cross-sectional modified Jones model with only CFO adjustments in the estimation process and based on total accruals - TAC $\left(\mathrm{DAC}_{3}\right) . \mathrm{DAC}_{5}(\mathrm{CMJM}$ with CFO adj. / CAC) stands for discretionary accruals (based on current accruals $\mathrm{CAC}$ ) from a cross-sectional modified Jones model with only CFO adjustments in the estimation process. $\mathrm{DAC}_{6}$ stands for performance and growth matched discretionary accruals from a cross-sectional modified Jones model with only CFO adjustments in the estimation process and based on current accruals $-\mathrm{CAC}\left(\mathrm{DAC}_{5}\right)$. For detailed information and definitions of the variables, see Appendix 5 - 14. The significance tests are based on t-test statistics (for the mean values) and Wilcoxon signed-ranks test statistics (for the median values). *** $(* *)(*)$ indicates significance levels at $1 \%(5 \%)(10 \%)$, one-tailed. 


\section{Appendix 5 - 10: Governance Role - Different DAC Measures}

Panel A. Cross-sectional modified Jones Model (CMJM) with CFO \& growth adjustments / TAC (DAC 2$)$

\begin{tabular}{lcccccc}
\hline Dependent variable: & \multicolumn{2}{c}{ Periods prior to the Stock Swap Transaction } & \multicolumn{3}{c}{ Periods after the Stock Swap Transaction } \\
\cline { 2 - 7 } DAC $_{2}$ & TRANS-1 & TRANS-1/-2 & TRANS-1/-3 & \multicolumn{1}{c}{ TRANS+1 } & \multicolumn{1}{c}{ TRANS+1/+2 } & TRANS+1/+3 \\
\hline GOV & $\mathbf{. 0 8 9 5 * *}$ & $\mathbf{. 0 9 4 8 * *}$ & $\mathbf{. 0 7 8 6 * * *}$ & $\mathbf{- . 0 2 2 3}$ & $\mathbf{. 0 0 4 9}$ & $\mathbf{- . 0 0 3 8}$ \\
& $\mathbf{( 2 . 2 7 )}$ & $\mathbf{( 2 . 1 9 )}$ & $\mathbf{( 2 . 8 1 )}$ & $\mathbf{( - 0 . 4 5 )}$ & $\mathbf{( 0 . 0 9 )}$ & $\mathbf{( - 0 . 1 0 )}$ \\
\hline M\&A Control & Yes & Yes & Yes & Yes & Yes & Yes \\
Firm Control & Yes & Yes & Yes & Yes & Yes & Yes \\
\hline Clustered se (1w) & Yes & No & No & Yes & No & No \\
Clustered se (2w) & No & Yes & Yes & No & Yes & Yes \\
\hline Adj. ${ }^{2}$ & .0521 & .0770 & .0940 & -.0966 & -.0297 & -.0169 \\
Sample Size & 66 & 128 & 188 & 67 & 130 & 189 \\
\hline
\end{tabular}

Panel B. Cross-sectional modified Jones Model (CMJM) with CFO adjustments / TAC (DAC 3 )

\begin{tabular}{lcccccc}
\hline Dependent variable: & \multicolumn{3}{c}{ Periods prior to the Stock Swap Transaction } & \multicolumn{3}{c}{ Periods after the Stock Swap Transaction } \\
\cline { 2 - 7 } DAC $_{3}$ & TRANS-1 & TRANS-1/-2 & TRANS-1/-3 & TRANS+1 & TRANS+1/+2 & TRANS+1/+3 \\
\hline GOV & $\mathbf{. 0 8 6 9 * *}$ & $\mathbf{. 0 7 9 8}$ & $\mathbf{. 0 8 0 6 * *}$ & $\mathbf{. 0 1 9 8}$ & $\mathbf{. 0 3 3 6}$ & $\mathbf{. 0 6 9 9}$ \\
& $\mathbf{( 2 . 7 0 )}$ & $\mathbf{( 1 . 5 9 )}$ & $\mathbf{( 2 . 3 1 )}$ & $\mathbf{( 0 . 2 5 )}$ & $\mathbf{( 0 . 4 7 )}$ & $\mathbf{( 1 . 1 5 )}$ \\
\hline M\&A Control & Yes & Yes & Yes & Yes & Yes & Yes \\
Firm Control & Yes & Yes & Yes & Yes & Yes & Yes \\
\hline Clustered se (1w) & Yes & Yes & Yes & Yes & Yes & Yes \\
Clustered se (2w) & No & Yes & Yes & No & Yes & Yes \\
\hline Adj. R & .1464 & .1350 & .1292 & -.0461 & -.0253 & .0057 \\
Sample Size & 66 & 128 & 188 & 67 & 130 & 189 \\
\hline
\end{tabular}

Panel C. ROA \& Growth matched discretionary accruals based on $\mathrm{DAC}_{3}$

\begin{tabular}{|c|c|c|c|c|c|c|}
\hline \multirow{2}{*}{$\begin{array}{l}\text { Dependent variable: } \\
\text { DAC }_{4}\end{array}$} & \multicolumn{3}{|c|}{ Periods prior to the Stock Swap Transaction } & \multicolumn{3}{|c|}{ Periods after the Stock Swap Transaction } \\
\hline & TRANS-1 & TRANS-1/-2 & TRANS-1/-3 & TRANS+1 & TRANS+1/+2 & TRANS+1/+3 \\
\hline GOV & $\begin{array}{l}.0545 \\
(1.10)\end{array}$ & $\begin{array}{l}.0103 \\
(0.22)\end{array}$ & $\begin{array}{l}-.0059 \\
(-0.19)\end{array}$ & $\begin{array}{l}-.0667 \\
(-0.64)\end{array}$ & $\begin{array}{l}.0037 \\
(0.04)\end{array}$ & $\begin{array}{l}.0263 \\
(0.37)\end{array}$ \\
\hline [GOV_dummy] & $\begin{array}{c}{[.0449 *]} \\
{[(1.98)]}\end{array}$ & $\begin{array}{l}{[.0178]} \\
{[(1.04)]}\end{array}$ & $\begin{array}{l}{[.0105]} \\
{[(0.52)]}\end{array}$ & $\begin{array}{l}{[-.0153]} \\
{[(-0.30)]}\end{array}$ & $\begin{array}{l}{[-.0059]} \\
{[(-0.15)]}\end{array}$ & $\begin{array}{l}{[.0124]} \\
{[(0.38)]}\end{array}$ \\
\hline M\&A Control & Yes & Yes & Yes & Yes & Yes & Yes \\
\hline Firm Control & Yes & Yes & Yes & Yes & Yes & Yes \\
\hline Clustered se $(1 \mathrm{w})$ & Yes & No & No & Yes & No & No \\
\hline Clustered se $(2 \mathrm{w})$ & No & Yes & Yes & No & Yes & Yes \\
\hline Adj. $R^{2}$ & .0819 & .0129 & .0046 & -.0090 & -.0106 & .0104 \\
\hline$\left[\right.$ Adj. $\left.R^{2}\right]$ & {$[.1063]$} & {$[.0165]$} & {$[.0057]$} & [-.0199] & [-.0101] & {$[.0102]$} \\
\hline Sample Size & 60 & 115 & 160 & 64 & 119 & 175 \\
\hline
\end{tabular}

Panel D. Cross-sectional modified Jones Model (CMJM) with CFO adjustments / CAC (DAC 5 )

\begin{tabular}{|c|c|c|c|c|c|c|}
\hline \multirow{2}{*}{$\begin{array}{l}\text { Dependent variable: } \\
\text { DAC }_{5}\end{array}$} & \multicolumn{3}{|c|}{ Periods prior to the Stock Swap Transaction } & \multicolumn{3}{|c|}{ Periods after the Stock Swap Transaction } \\
\hline & TRANS-1 & TRANS-1/-2 & TRANS-1/-3 & TRANS+1 & TRANS+1/+2 & TRANS+1/+3 \\
\hline GOV & $\begin{array}{c}.1009 * * * \\
(3.07)\end{array}$ & $\begin{array}{l}.1110^{*} \\
(1.93)\end{array}$ & $\begin{array}{c}.1134 * * \\
(2.26)\end{array}$ & $\begin{array}{l}.0583 \\
(0.67)\end{array}$ & $\begin{array}{l}.0699 \\
(0.87)\end{array}$ & $\begin{array}{l}.0993 \\
(1.49)\end{array}$ \\
\hline M\&A Control & Yes & Yes & Yes & Yes & Yes & Yes \\
\hline Firm Control & Yes & Yes & Yes & Yes & Yes & Yes \\
\hline Clustered se $(1 \mathrm{w})$ & Yes & No & No & Yes & No & No \\
\hline Clustered se (2w) & No & Yes & Yes & No & Yes & Yes \\
\hline Adj. $\mathrm{R}^{2}$ & .2461 & .1951 & .1794 & -.0276 & -.0107 & .0143 \\
\hline Sample Size & 66 & 128 & 188 & 67 & 130 & 189 \\
\hline
\end{tabular}

Panel E. ROA \& Growth matched discretionary accruals based on $\mathrm{DAC}_{5}$

\begin{tabular}{|c|c|c|c|c|c|c|}
\hline \multirow{2}{*}{$\begin{array}{l}\text { Dependent variable: } \\
\text { DAC }_{6}\end{array}$} & \multicolumn{3}{|c|}{ Periods prior to the Stock Swap Transaction } & \multicolumn{3}{|c|}{ Periods after the Stock Swap Transaction } \\
\hline & TRANS-1 & TRANS-1/-2 & TRANS-1/-3 & TRANS+1 & TRANS+1/+2 & TRANS+1/+3 \\
\hline GOV & $\begin{array}{l}.0870^{*} \\
(1.96)\end{array}$ & $\begin{array}{l}.0534 \\
(0.81)\end{array}$ & $\begin{array}{l}.0256 \\
(0.47) \\
\end{array}$ & $\begin{array}{l}-.0607 \\
(-0.53)\end{array}$ & $\begin{array}{l}.0428 \\
(0.40)\end{array}$ & $\begin{array}{l}.0663 \\
(0.79) \\
\end{array}$ \\
\hline M\&A Control & Yes & Yes & Yes & Yes & Yes & Yes \\
\hline Firm Control & Yes & Yes & Yes & Yes & Yes & Yes \\
\hline Clustered se (1w) & Yes & No & No & Yes & No & No \\
\hline Clustered se (2w) & No & Yes & Yes & No & Yes & Yes \\
\hline Adj. $\mathrm{R}^{2}$ & .0783 & .0100 & .0073 & .0518 & .0194 & .0121 \\
\hline Sample Size & 60 & 115 & 160 & 64 & 120 & 177 \\
\hline
\end{tabular}

Notes: The underlying regression model is:

DACadj $_{\text {it }}=\alpha+\gamma_{1}$ GOV $_{\text {it }}+\sum \gamma_{2}$ M\&A_CONTROL $_{i t}+\sum \gamma_{3}$ FIRM_CONTROL $_{i t}+\varepsilon$

Where $\alpha$ represents the constant term, $\gamma_{1}-\sum \gamma_{3}$ are the coefficients of the explanatory variables, and $\varepsilon$ is the error term. The dependent variable DACadj represents discretionary accruals obtained from an extended cross- 
sectional modified Jones model and measures accrual-based earnings management. In particular, $\mathrm{DAC}_{2}(\mathrm{CMJM}$ with CFO \& Growth adj. / TAC) stands for discretionary accruals (based on total accruals - TAC) from a crosssectional modified Jones model with CFO and growth adjustments in the estimation process. $\mathrm{DAC}_{3}(\mathrm{CMJM}$ with CFO adj. / TAC) stands for discretionary accruals (based on total accruals - TAC) from a cross-sectional modified Jones model with only $\mathrm{CFO}$ adjustments in the estimation process. $\mathrm{DAC}_{4}$ stands for performance and growth matched discretionary accruals from a cross-sectional modified Jones model with only CFO adjustments in the estimation process and based on total accruals - TAC (DAC 3$). \mathrm{DAC}_{5}(\mathrm{CMJM}$ with CFO adj. / CAC) stands for discretionary accruals (based on current accruals - CAC) from a cross-sectional modified Jones model with only $\mathrm{CFO}$ adjustments in the estimation process. $\mathrm{DAC}_{6}$ stands for performance and growth matched discretionary accruals from a cross-sectional modified Jones model with only CFO adjustments in the estimation process and based on current accruals - CAC $\left(\mathrm{DAC}_{5}\right)$. M\&A_CONTROL represents a vector of M\&A characteristics (relative deal size, industrial relatedness, and percentage of stock financing). FIRM_CONTROL represents a vector of firm characteristics (size as log of market value/log of total assets, leverage, ownership concentration, and big five auditor). For detailed information and definitions of the variables, see Appendix 5 14. The regression models have standard errors which are heteroskedasticity robust and - as indicated - one-way clustered at year level or two-way clustered at firm and year level. Reported values: coefficient (t-value) $* * *$ $(* *)(*)$ indicates significance levels at 1\% (5\%) (10\%), two-tailed. 
Appendix 5 - 11: Governance Role - Different Governance Proxies

Panel A. Dummy variable based on all GOV ISS rated UK firms $\left(\boldsymbol{G O} \boldsymbol{V}_{-} \boldsymbol{d u m} \boldsymbol{m} \boldsymbol{y}\right)$

\begin{tabular}{|c|c|c|c|c|c|c|}
\hline \multirow{2}{*}{$\begin{array}{l}\text { Dependent variable: } \\
\text { DAC }\end{array}$} & \multicolumn{3}{|c|}{ Periods prior to the Stock Swap Transaction } & \multicolumn{3}{|c|}{ Periods after the Stock Swap Transaction } \\
\hline & TRANS-1 & TRANS-1/-2 & TRANS-1/-3 & TRANS+1 & TRANS+1/+2 & TRANS+1/+3 \\
\hline GOV_dummy & $\begin{array}{l}.0413 * \\
(2.02)\end{array}$ & $\begin{array}{c}.0509 * * * \\
(3.02)\end{array}$ & $\begin{array}{c}.0430 * * \\
(2.41)\end{array}$ & $\begin{array}{l}-.0344 \\
(-1.02)\end{array}$ & $\begin{array}{l}-.0197 \\
(-0.65)\end{array}$ & $\begin{array}{l}-.0089 \\
(-0.42)\end{array}$ \\
\hline M\&A Control & Yes & Yes & Yes & Yes & Yes & Yes \\
\hline Firm Control & Yes & Yes & Yes & Yes & Yes & Yes \\
\hline Clustered se (1w) & Yes & No & No & Yes & No & No \\
\hline Clustered se (2w) & No & Yes & Yes & No & Yes & Yes \\
\hline Adj. $R^{2}$ & .0995 & .0748 & .1043 & -.0745 & -.0149 & -.0070 \\
\hline Sample Size & 66 & 128 & 188 & 67 & 130 & 189 \\
\hline
\end{tabular}

Panel B. GOV score based on median $\mathrm{GOV}_{\mathrm{ISS}}$ scores (GOV_median)

\begin{tabular}{lcccccc}
\hline Dependent variable: & \multicolumn{2}{c}{ Periods prior to the Stock Swap Transaction } & \multicolumn{3}{c}{ Periods after the Stock Swap Transaction } \\
\cline { 2 - 7 } DAC & TRANS-1 & TRANS-1/-2 & TRANS-1/-3 & TRANS+1 & TRANS+1/+2 & TRANS+1/+3 \\
\hline GOV_median & $\mathbf{. 0 6 9 1 * *}$ & $\mathbf{. 0 9 7 1 * *}$ & $\mathbf{. 0 8 4 9 * * *}$ & $\mathbf{- . 0 2 9 0}$ & $\mathbf{. 0 0 0 5}$ & $\mathbf{. 0 0 7 9}$ \\
& $\mathbf{( 2 . 3 5 )}$ & $\mathbf{( 2 . 3 6 )}$ & $\mathbf{( 2 . 6 0 )}$ & $\mathbf{( - 0 . 8 3 )}$ & $\mathbf{( 0 . 0 1 )}$ & (0.24) \\
\hline M\&A Control & Yes & Yes & Yes & Yes & Yes & Yes \\
Firm Control & Yes & Yes & Yes & Yes & Yes & Yes \\
\hline Clustered se (1w) & Yes & No & No & Yes & No & No \\
Clustered se (2w) & No & Yes & Yes & No & Yes & Yes \\
\hline Adj. R & .0989 & .0840 & .1138 & -.0922 & -.0227 & -.0083 \\
Sample Size & 66 & 128 & 188 & 67 & 130 & 189 \\
\hline
\end{tabular}

Panel C. GOV score based on the TOP $10 \%$ governed firms based on GOV (GOV_Top10\%)

\begin{tabular}{|c|c|c|c|c|c|c|}
\hline \multirow{2}{*}{$\begin{array}{l}\text { Dependent variable: } \\
\text { DAC }\end{array}$} & \multicolumn{3}{|c|}{ Periods prior to the Stock Swap Transaction } & \multicolumn{3}{|c|}{ Periods after the Stock Swap Transaction } \\
\hline & TRANS-1 & TRANS-1/-2 & TRANS-1/-3 & TRANS+1 & TRANS+1/+2 & TRANS+1/+3 \\
\hline GOV_Top10\% & $\begin{array}{c}.0744 * * * \\
(3.41)\end{array}$ & $\begin{array}{c}.0577^{*} \\
(1.75)\end{array}$ & $\begin{array}{c}.0586 * * \\
(1.99)\end{array}$ & $\begin{array}{c}.0623 * \\
(1.80)\end{array}$ & $\begin{array}{c}.0708 * * * \\
(2.85)\end{array}$ & $\begin{array}{c}.0514 * * \\
(2.57)\end{array}$ \\
\hline M\&A Control & Yes & Yes & Yes & Yes & Yes & Yes \\
\hline Firm Control & Yes & Yes & Yes & Yes & Yes & Yes \\
\hline Clustered se (1w) & Yes & No & No & Yes & No & No \\
\hline Clustered se (2w) & No & Yes & Yes & No & Yes & Yes \\
\hline Adj. $\mathrm{R}^{2}$ & .1446 & .0612 & .1033 & -.0605 & .0216 & .0151 \\
\hline Sample Size & 66 & 128 & 188 & 67 & 130 & 189 \\
\hline
\end{tabular}

Panel D. GOV score based on Principal Component Analysis (GOV_pca)

\begin{tabular}{|c|c|c|c|c|c|c|}
\hline \multirow{2}{*}{$\begin{array}{l}\text { Dependent variable: } \\
\text { DAC }\end{array}$} & \multicolumn{3}{|c|}{ Periods prior to the Stock Swap Transaction } & \multicolumn{3}{|c|}{ Periods after the Stock Swap Transaction } \\
\hline & TRANS-1 & TRANS-1/-2 & TRANS-1/-3 & TRANS+1 & TRANS+1/+2 & TRANS+1/+3 \\
\hline GOV_pca & $\begin{array}{c}.0164 * * \\
(2.23)\end{array}$ & $\begin{array}{c}.0223 * * \\
(2.36)\end{array}$ & $\begin{array}{c}.0184 * * * \\
(2.72)\end{array}$ & $\begin{array}{l}-.0057 \\
(-\mathbf{0 . 6 3 )}\end{array}$ & $\begin{array}{l}-.0014 \\
(-0.12)\end{array}$ & $\begin{array}{l}.0010 \\
(0.14)\end{array}$ \\
\hline M\&A Control & Yes & Yes & Yes & Yes & Yes & Yes \\
\hline Firm Control & Yes & Yes & Yes & Yes & Yes & Yes \\
\hline Clustered se (1w) & Yes & No & No & Yes & No & No \\
\hline Clustered se (2w) & No & Yes & Yes & No & Yes & Yes \\
\hline Adj. $\mathrm{R}^{2}$ & .1207 & .0982 & .1199 & -.0925 & -.0224 & -.0086 \\
\hline Sample Size & 66 & 128 & 188 & 67 & 130 & 189 \\
\hline
\end{tabular}

Panel E. GOV scores based on splitting and summing up the underlying GOV criteria in monitoring and incentive measures

\begin{tabular}{|c|c|c|c|c|c|c|}
\hline \multirow{2}{*}{$\begin{array}{l}\text { Dependent variable: } \\
\text { DAC }\end{array}$} & \multicolumn{3}{|c|}{ Periods prior to the Stock Swap Transaction } & \multicolumn{3}{|c|}{ Periods after the Stock Swap Transaction } \\
\hline & TRANS-1 & TRANS-1/-2 & TRANS-1/-3 & TRANS+1 & TRANS+1/+2 & TRANS $+1 /+3$ \\
\hline \multirow[t]{2}{*}{ GOV_monitor } & .0161 & .0393 & .0309 & -.0150 & -.0058 & .0059 \\
\hline & $(\mathbf{0 . 8 7})$ & (1.62) & (1.65) & $(-0.59)$ & $(-0.17)$ & $(0.28)$ \\
\hline \multirow[t]{2}{*}{ GOV_incentives } & $.0744 * * *$ & $.0583 * *$ & $.0567 * * *$ & .0220 & .0323 & .0161 \\
\hline & (3.80) & $(2.45)$ & (3.09) & $(0.52)$ & $(1.43)$ & $(0.80)$ \\
\hline M\&A Control & Yes & Yes & Yes & Yes & Yes & Yes \\
\hline Firm Control & Yes & Yes & Yes & Yes & Yes & Yes \\
\hline Clustered se (1w) & Yes & No & No & Yes & No & No \\
\hline Clustered se (2w) & No & Yes & Yes & No & Yes & Yes \\
\hline Adj. $\mathrm{R}^{2}$ & .1455 & .0824 & .1147 & -.1104 & -.0212 & -.0101 \\
\hline Sample Size & 66 & 128 & 188 & 67 & 130 & 189 \\
\hline
\end{tabular}

Notes: The underlying regression model is:

DAC $_{i t}=\alpha+\gamma_{1}$ CG $_{i t}+\sum \gamma_{2}$ M\&A_CONTROL $_{i t}+\sum \gamma_{3}$ FIRM_CONTROL $_{\text {it }}+\varepsilon$

Where $\alpha$ represents the constant term, $\gamma_{1}-\sum \gamma_{3}$ are the coefficients of the explanatory variables, and $\varepsilon$ is the error term. The dependent variable DAC represents discretionary accruals obtained from an extended (CFO and 
growth adjusted) cross-sectional modified Jones model. CG stands for different scores to proxy firm-level governance quality. In particular, GOV_dummy is a dummy variables indicating strong (with 1) and poor (with 0 ) governance quality based on the distribution of all available UK governance scores (GOV). GOV_median is based on a self-constructed governance rating (GOV ISS $)$ using ISS CGQ raw data from 2003 to 2007 , and averaged (taking median instead of mean values of $\mathrm{GOV}_{\text {ISS }}$ ) for our sample period. GOV_Top $10 \%$ is a dummy variable taking the value of one if the acquirer's governance measure $(\mathrm{GOV})$ belongs to the $10^{\text {th }}$ deciles, and zero otherwise. GOV_pca is a governance score based on Principal Component Analysis where the averaged principal component - estimated on six sub-scores which are based on UK firm-level ISS rating data from the years 2003 to 2007 - with the highest eigenvalue is used to proxy governance for our sample period (1998 to 2011). GOV monitor (GOV incentives) is a governance score based on the GOV ISs subcategories: board, audit, charter, anti-takeover, and progressive practice (compensation and managerial ownership) and is based on the individual firm governance data $\left(\mathrm{GOV}_{\mathrm{ISS}}\right)$ from 2003 to 2007 and is averaged for the M\&A sample period. M\&A_CONTROL represents a vector of M\&A characteristics (relative deal size, industrial relatedness, and percentage of stock financing). FIRM_CONTROL represents a vector of firm characteristics (size, leverage, ownership concentration, and big five auditor). For detailed information and definitions of the variables, see Appendix 5 - 14. The regression models have standard errors which are heteroskedasticity robust and - as indicated - one-way clustered at year level or two-way clustered at firm and year level. Reported values: coefficient $(\mathrm{t}$-value $) * * *(* *)(*)$ indicates significance levels at $1 \%(5 \%)(10 \%)$, two-tailed. 
Appendix 5 - 12: Governance-Performance: Stickiness of Governance

\begin{tabular}{|c|c|c|c|c|c|c|c|c|c|c|}
\hline \multirow{3}{*}{ Variables } & \multirow{3}{*}{$\begin{array}{l}\text { Pred. } \\
\text { Sign }\end{array}$} & \multicolumn{9}{|c|}{ Dependent variable: Tobin's $Q$} \\
\hline & & \multicolumn{3}{|c|}{ All Firms } & \multicolumn{3}{|c|}{ Stock Acquirers } & \multicolumn{3}{|c|}{ Non (Stock) Acquirers } \\
\hline & & Model 1 & Model 2 & Model 3 & Model 4 & Model 5 & Model 6 & Model 7 & Model 8 & Model 9 \\
\hline GOV & + & $\begin{array}{c}.255^{* * *} \\
(3.01)\end{array}$ & & & $\begin{array}{c}.3041 \\
(1.62)\end{array}$ & & & $\begin{array}{c}.256^{* * *} \\
(2.69)\end{array}$ & & \\
\hline GOV_dummy & + & & $\begin{array}{l}.0716^{*} \\
(1.91)\end{array}$ & & & $\begin{array}{l}.0540 \\
(0.65)\end{array}$ & & & $\begin{array}{l}.0808^{*} \\
(1.96)\end{array}$ & \\
\hline GOV $_{\text {ISS }}$ & + & & & - & & & - & & & - \\
\hline Firm control & & Yes & Yes & - & Yes & Yes & - & Yes & Yes & - \\
\hline Year fe & & Yes & Yes & - & Yes & Yes & - & Yes & Yes & - \\
\hline Industry fe & & Yes & Yes & - & Yes & Yes & - & Yes & Yes & - \\
\hline Clustered se & & Yes & Yes & - & Yes & Yes & - & Yes & Yes & - \\
\hline Adj. $R^{2}$ & & .2582 & .2533 & - & .3374 & .3300 & - & .2485 & .2442 & - \\
\hline Sample Size & & 3913 & 3913 & - & 835 & 835 & - & 3078 & 3078 & - \\
\hline
\end{tabular}

Panel B: Holistic Approach: Governance-Performance Regression (sample: 2003 to 2007)

\begin{tabular}{|c|c|c|c|c|c|c|c|c|c|c|}
\hline \multirow{3}{*}{ Variables } & \multirow{3}{*}{$\begin{array}{l}\text { Pred. } \\
\text { Sign }\end{array}$} & \multicolumn{9}{|c|}{ Dependent variable: Tobin's $Q$} \\
\hline & & \multicolumn{3}{|c|}{ All Firms } & \multicolumn{3}{|c|}{ Stock Acquirers } & \multicolumn{3}{|c|}{ Non (Stock) Acquirers } \\
\hline & & Model 1 & Model 2 & Model 3 & Model 4 & Model 5 & Model 6 & Model 7 & Model 8 & Model 9 \\
\hline GOV & + & $\begin{array}{c}.274 * * * \\
(2.94)\end{array}$ & & & $\begin{array}{l}.3844^{*} \\
(1.74)\end{array}$ & & & $\begin{array}{c}.2308 * * \\
(2.21)\end{array}$ & & \\
\hline GOV_dummy & + & & $\begin{array}{l}.0710^{*} \\
(1.72)\end{array}$ & & & $\begin{array}{l}.0868 \\
(0.86)\end{array}$ & & & $\begin{array}{l}.0592 \\
(1.30)\end{array}$ & \\
\hline GOV $_{\text {ISS }}$ & + & & & $\begin{array}{c}.164 * * * \\
(2.94)\end{array}$ & & & $\begin{array}{l}.2478^{*} \\
(1.81)\end{array}$ & & & $\begin{array}{c}.1402 * * \\
(2.34)\end{array}$ \\
\hline Firm control & & Yes & Yes & Yes & Yes & Yes & Yes & Yes & Yes & Yes \\
\hline Year fe & & Yes & Yes & Yes & Yes & Yes & Yes & Yes & Yes & Yes \\
\hline Industry fe & & Yes & Yes & Yes & Yes & Yes & Yes & Yes & Yes & Yes \\
\hline Clustered se & & Yes & Yes & Yes & Yes & Yes & Yes & Yes & Yes & Yes \\
\hline Adj. $R^{2}$ & & .2641 & .2564 & .2599 & .2501 & .2342 & .2453 & .2897 & .2842 & .2868 \\
\hline Sample Size & & 1239 & 1239 & 1239 & 272 & 272 & 272 & 967 & 967 & 967 \\
\hline
\end{tabular}

Notes: The underlying pooled regression model is:

$\mathrm{VAL}_{\mathrm{it}}=\alpha+\beta_{1} \mathrm{GG}_{\mathrm{it}}+\sum \beta_{2}$ FIRM_CONTROL $_{\mathrm{it}}+\sum \beta_{3}$ YEAR $_{\mathrm{it}}+\sum \beta_{4}$ INDUSTRY $_{\mathrm{it}}+\varepsilon$

Where $\alpha$ represents the constant term, $\beta_{1}-\sum \beta_{4}$ are the coefficients of the explanatory variables, and $\varepsilon$ is the error term. The dependent variable VAL stands for Tobin's Q. Tobin's Q measures firm valuation by market value deflated by total assets. CG stands for different scores to proxy firm-level governance quality. In particular, GOV is based on a self-constructed governance rating $\left(\mathrm{GOV}_{\text {ISS }}\right)$ using ISS CGQ raw data from 2003 to 2007 , and averaged (taking mean values from $\mathrm{GOV}_{\text {ISS }}$ ) for our sample period (1998 to 2011). GOV_dummy is the corresponding dummy variable taking the value of one if the firm's governance measure (GOV) is above its mean value, and zero otherwise (based on total UK ISS population). $\mathrm{GOV}_{\text {ISS }}$ is a self-constructed governance score based on UK ISS CGQ raw data and is only available from 2003 to 2007. FIRM_CONTROL1 represents a vector of firm characteristics (size, leverage, past average three-year growth in net sales, capital-intensity, and blue chip index membership). For detailed information and definitions of the variables, see Appendix 5 - 14. The regression models contain year- and industry-fixed effects, and have standard errors which are heteroskedasticity robust and one-way clustered at firm level. Reported values: coefficient (t-value) *** $(* *)(*)$ indicates significance levels at $1 \%(5 \%)(10 \%)$, two-tailed. 
Appendix 5 - 13: Governance Role - Additional Control Variables

\begin{tabular}{|c|c|c|c|c|c|c|}
\hline \multirow[b]{3}{*}{ Variables } & \multicolumn{6}{|c|}{ Dependent variable: Discretionary Accruals (CMJM with CFO \& Growth adj./ CAC) } \\
\hline & \multicolumn{3}{|c|}{ Full Set of Control Variables } & \multicolumn{3}{|c|}{ Stepwise Regression Technique } \\
\hline & $\begin{array}{l}\text { TRANS-1 } \\
\text { Model } 1\end{array}$ & $\begin{array}{c}\text { TRANS-1/-2 } \\
\text { Model } 2\end{array}$ & $\begin{array}{c}\text { TRANS-1/-3 } \\
\text { Model } 3\end{array}$ & $\begin{array}{c}\text { TRANS-1 } \\
\text { Model } 4 \\
\text { (forward) } \\
\end{array}$ & $\begin{array}{c}\text { TRANS-1 } \\
\text { Model } 5 \\
\text { (backward) }\end{array}$ & $\begin{array}{c}\text { TRANS-1 } \\
\text { Model } 6 \\
(M 4+M 5)\end{array}$ \\
\hline Intercept & $\begin{array}{l}.1555^{*} \\
(1.93)\end{array}$ & $\begin{array}{l}.2944 * \\
(1.95)\end{array}$ & $\begin{array}{c}.3063 * * \\
(2.30)\end{array}$ & $\begin{array}{c}.1478 * * \\
(3.19)\end{array}$ & $\begin{array}{c}.1737 * * \\
(2.77)\end{array}$ & $\begin{array}{c}.1490 * * * \\
(4.02)\end{array}$ \\
\hline GOV & $\begin{array}{c}.0733 * * * \\
(3.67)\end{array}$ & $\begin{array}{c}.1366 * * * \\
(2.87)\end{array}$ & $\begin{array}{c}.1022 * * * \\
(4.73)\end{array}$ & $\begin{array}{c}.0881 * * * \\
(3.37)\end{array}$ & $\begin{array}{c}.0582 * * \\
(2.50)\end{array}$ & $\begin{array}{c}.0943 * * \\
(2.98) \\
\end{array}$ \\
\hline DEAL SIZE & $\begin{array}{l}-.0001 \\
(-1.32)\end{array}$ & $\begin{array}{l}-.0000 \\
(-1.37)\end{array}$ & $\begin{array}{c}-.0000^{*} \\
(-1.85)\end{array}$ & $\begin{array}{c}-.0001 * * * \\
(-4.14)\end{array}$ & $\begin{array}{c}-.0001 * * * \\
(-3.23)\end{array}$ & $\begin{array}{c}-.0001 * * * \\
(-3.53)\end{array}$ \\
\hline IND RELATEDNESS & $\begin{array}{c}-.0428 * * \\
(-2.39)\end{array}$ & $\begin{array}{l}.0065 \\
(0.21)\end{array}$ & $\begin{array}{l}.0166 \\
(0.89)\end{array}$ & & $\begin{array}{c}-.0293 * * \\
(-2.58)\end{array}$ & \\
\hline STOCK & $\begin{array}{l}.0003 \\
(0.62)\end{array}$ & $\begin{array}{l}-.0004 \\
(-1.04)\end{array}$ & $\begin{array}{l}-.0002 \\
(-0.58)\end{array}$ & & & \\
\hline BIG FIVE & $\begin{array}{l}-0562 \\
(-1.26)\end{array}$ & $\begin{array}{c}-.1816^{* * * *} \\
(-2.64)\end{array}$ & $\begin{array}{c}-.1564 * * \\
(-2.10)\end{array}$ & & & \\
\hline OWNER & $\begin{array}{l}.0011 \\
(0.24)\end{array}$ & $\begin{array}{l}.0016 \\
(0.37)\end{array}$ & $\begin{array}{l}-.0014 \\
(-0.54)\end{array}$ & & & \\
\hline SIZE & $\begin{array}{l}-.0070 \\
(-1.20)\end{array}$ & $\begin{array}{l}-.0014 \\
(-0.21)\end{array}$ & $\begin{array}{l}-.0041 \\
(-0.76)\end{array}$ & $\begin{array}{c}-.0088 * * \\
(-2.74)\end{array}$ & $\begin{array}{c}-.0096 * * \\
(-2.54)\end{array}$ & $\begin{array}{c}-.0144 * * * \\
(-6.82)\end{array}$ \\
\hline LEV & $\begin{array}{l}.0892 * \\
(2.10)\end{array}$ & $\begin{array}{l}.0111 \\
(0.20) \\
\end{array}$ & $\begin{array}{r}.0494 \\
(1.60) \\
\end{array}$ & $\begin{array}{l}.0702 * \\
(1.88) \\
\end{array}$ & $\begin{array}{c}.1059 * * \\
(2.78) \\
\end{array}$ & $\begin{array}{r}.0793^{*} \\
(1.95) \\
\end{array}$ \\
\hline Cross-border & $\begin{array}{l}-.0377 \\
(-1.72)\end{array}$ & $\begin{array}{c}-.0751 * * * \\
(-3.91)\end{array}$ & $\begin{array}{c}-.0546^{* * *} \\
(-3.61)\end{array}$ & $\begin{array}{c}-.0374 * \\
(-2.09)\end{array}$ & $\begin{array}{c}-.0481 * * * \\
(-3.64)\end{array}$ & $\begin{array}{l}-.0292 \\
(-1.67)\end{array}$ \\
\hline Completed & $\begin{array}{l}-.0224 \\
(-1.07)\end{array}$ & $\begin{array}{l}.0122 \\
(0.61)\end{array}$ & $\begin{array}{l}.0001 \\
(0.01)\end{array}$ & & & \\
\hline Voting Rights & $\begin{array}{l}.0112 \\
(0.20)\end{array}$ & $\begin{array}{l}.0844 \\
(1.30)\end{array}$ & $\begin{array}{l}.0386 \\
(0.78)\end{array}$ & & & \\
\hline M\&A Activity & $\begin{array}{l}-.0195 \\
(-0.98)\end{array}$ & $\begin{array}{l}.0064 \\
(0.31)\end{array}$ & $\begin{array}{l}-.0048 \\
(-0.37)\end{array}$ & & $\begin{array}{c}-.0246^{* *} \\
(-2.43)\end{array}$ & \\
\hline Deal Timing & $\begin{array}{c}.0048 \\
(1.34)\end{array}$ & $\begin{array}{l}.0043 \\
(1.23)\end{array}$ & $\begin{array}{l}.0007 \\
(0.22)\end{array}$ & & & \\
\hline Deal Duration & $\begin{array}{l}-.0026 \\
(-1.27)\end{array}$ & $\begin{array}{l}-.0019 \\
(-1.28)\end{array}$ & $\begin{array}{l}.0012 \\
(1.20)\end{array}$ & & & \\
\hline Tender Offer & $\begin{array}{l}.0083 \\
(0.51)\end{array}$ & $\begin{array}{l}-.0214 \\
(-1.24)\end{array}$ & $\begin{array}{l}-.0206 \\
(-1.72)\end{array}$ & & & \\
\hline Analyst REC & $\begin{array}{c}.0538 * * * \\
(4.74)\end{array}$ & $\begin{array}{c}.0383 * * * \\
(3.79)\end{array}$ & $\begin{array}{l}.0139 \\
(1.41)\end{array}$ & $\begin{array}{c}.0569 * * * \\
(4.18)\end{array}$ & $\begin{array}{c}.0481 * * * \\
(5.63)\end{array}$ & $\begin{array}{c}.0457 * * * \\
(3.96)\end{array}$ \\
\hline Analyst COV & $\begin{array}{l}-.0110 \\
(-0.46)\end{array}$ & $\begin{array}{l}-.0046 \\
(-0.12)\end{array}$ & $\begin{array}{l}-.0151 \\
(-0.45)\end{array}$ & $\begin{array}{c}-.0580 * * \\
(-2.75)\end{array}$ & & \\
\hline M\&A Waves & $\begin{array}{l}-.0318 \\
(-1.14)\end{array}$ & $\begin{array}{l}-.0208 \\
(-0.79)\end{array}$ & $\begin{array}{l}-.0145 \\
(-1.04)\end{array}$ & & $\begin{array}{l}-.0296 \\
(-1.57)\end{array}$ & \\
\hline IFRS & $\begin{array}{l}-.0300 \\
(-1.03)\end{array}$ & $\begin{array}{l}-.0112 \\
(-0.40)\end{array}$ & $\begin{array}{l}-.0213 \\
(-0.84)\end{array}$ & & $\begin{array}{l}-.0229 \\
(-1.61)\end{array}$ & \\
\hline BTM & $\begin{array}{l}-.0040 \\
(-0.16)\end{array}$ & $\begin{array}{l}-.0790 \\
(-1.08)\end{array}$ & $\begin{array}{l}-.0621 \\
(-1.28)\end{array}$ & $\begin{array}{c}-.0378 * * * \\
(-3.34)\end{array}$ & & \\
\hline $\mathrm{CFO}$ & $\begin{array}{l}.1626 \\
(1.76)\end{array}$ & $\begin{array}{l}.0364 \\
(0.40)\end{array}$ & $\begin{array}{l}-.0652 \\
(-0.68)\end{array}$ & & & \\
\hline Audit Fees & $\begin{array}{l}.0323 \\
(0.22) \\
\end{array}$ & $\begin{array}{l}-.0344 \\
(-0.19) \\
\end{array}$ & $\begin{array}{l}-.0497 \\
(-0.42)\end{array}$ & $\begin{array}{c}-.2436 * * * \\
(-4.67)\end{array}$ & & \\
\hline Industry fe & Yes & Yes & Yes & [Yes] & [Yes] & [Yes] \\
\hline Clustered se (1w) & Yes & No & No & Yes & Yes & Yes \\
\hline Clustered se (2w) & No & Yes & Yes & No & No & No \\
\hline $\mathrm{pe}()$ & - & - & - & 0.10 & 0.10 & 0.10 \\
\hline $\operatorname{pr}()$ & - & - & - & 0.15 & 0.15 & 0.15 \\
\hline Adj. $R^{2}$ & 0.2196 & 0.1818 & 0.1723 & 0.2666 & 0.3455 & 0.2236 \\
\hline Sample Size & 66 & 128 & 186 & 66 & 66 & 66 \\
\hline
\end{tabular}

Notes: The underlying regression model is:

DAC $_{\text {it }}=\alpha+\gamma_{1}$ GOV $_{\text {it }}+\sum \gamma_{2}$ M\&A_CONTROL $_{i t}+\sum \gamma_{3}$ FIRM_CONTROL $_{\text {it }}+\sum \gamma_{4}$ INDUSTRY $_{\text {it }}+\varepsilon$

The dependent variable DAC represents discretionary accruals obtained from an cross-sectional modified Jones model. GOV measures CG quality. M\&A_CONTROL represents a vector of M\&A characteristics (relative deal size, industrial relatedness, percentage of stock financing, cross-border deal, deal completed, majority voting rights transferred, M\&A activity, strategic deal timing, duration of the deal negotiation, tender offer, M\&A waves). FIRM_CONTROL represents a vector of firm characteristics (size, leverage, book-to-market of equity, cash from operations, ownership concentration, big five auditor, fees paid for auditing, analyst recommendation, analyst coverage, and IFRS reporting). Stepwise regressions (Model 4 and 5) are executed in two versions (forward and backward stepwise) to select the independent variables pursuant pre-specified significance levels 
for removal $(\mathrm{pr}=0.15)$ and for addition ( $\mathrm{pe}=0.10)$. Since firm size plays a crucial role in our setting (it is negatively correlated with earnings management but positively with governance quality; see Table 5 - 4), we include jointly CG quality and firm size in the stepwise regressions. For variable definition, see Appendix 5 - 14. The regressions contain industry-fixed effects, and have robust standard errors which are as indicated one-way clustered at year level or two-way clustered at firm and year level. Reported values: coefficient (t-value) *** $(* *)(*)$ indicates significance levels at 1\% (5\%) (10\%), two-tailed. 
Appendix 5 - 14: Definition of Variables

\begin{tabular}{|c|c|c|}
\hline SHORT CUT & VARIABLE & DEFINITION \\
\hline \multicolumn{3}{|c|}{ Discretionary Accruals (Source: Worldscope database) } \\
\hline DAC* & $\begin{array}{l}\text { Discretionary accruals } \\
\text { (specification } 1 \text { ) }\end{array}$ & $\begin{array}{l}D A C \text { are the residuals from an extended (growth \& CFO adj.) cross- } \\
\text { sectional modified Jones model (CMJM) based on the cash flow approach } \\
\text { and current (working capital) accruals (CAC) }\end{array}$ \\
\hline $\mathrm{DAC}_{2} *$ & $\begin{array}{l}\text { Discretionary accruals } \\
\text { (specification 2) }\end{array}$ & $\begin{array}{l}D A C_{2} \text { are the residuals from an extended (growth \& CFO adj.) cross- } \\
\text { sectional modified Jones model (CMJM) based on the cash flow approach } \\
\text { and total accruals (TAC) }\end{array}$ \\
\hline $\mathrm{DAC}_{3} *$ & $\begin{array}{l}\text { Discretionary accruals } \\
\text { (specification } 3 \text { ) }\end{array}$ & $\begin{array}{l}\left.D A C C_{3} \text { are the residuals from an extended ( } \mathrm{CFO} \text { adj. }\right) \text { cross-sectional } \\
\text { modified Jones model (CMJM) based on the cash flow approach and total } \\
\text { accruals (TAC) }\end{array}$ \\
\hline $\mathrm{DAC}_{4} *$ & $\begin{array}{l}\text { Discretionary accruals } \\
\text { (specification } 4 \text { ) }\end{array}$ & $\begin{array}{l}D A C_{4} \text { are } \mathrm{DAC}_{3} \text { adjusted by matching control firms based on fiscal year, } \\
\text { two-digit industry group, ROA and growth }\end{array}$ \\
\hline $\mathrm{DAC}_{5} *$ & $\begin{array}{l}\text { Discretionary accruals } \\
\text { (specification } 3 \text { ) }\end{array}$ & $\begin{array}{l}D A C_{5} \text { are the residuals from an extended (CFO adj.) cross-sectional } \\
\text { modified Jones model (CMJM) based on the cash flow approach and } \\
\text { current (working capital) accruals (CAC) }\end{array}$ \\
\hline $\mathrm{DAC}_{6} *$ & $\begin{array}{l}\text { Discretionary accruals } \\
\text { (specification } 4 \text { ) }\end{array}$ & $\begin{array}{l}D A C_{6} \text { are } \mathrm{DAC}_{5} \text { adjusted by matching control firms based on fiscal year, } \\
\text { two-digit industry group, ROA and growth }\end{array}$ \\
\hline CAC*\# & $\begin{array}{l}\text { Current (working } \\
\text { capital) accruals }\end{array}$ & $\begin{array}{l}C A C \text { is current accruals }=\text { net income }(w c 01751)-\text { cash from operations } \\
(w c 04860)-\text { depreciation, depletion } \& \text { amortization }(w c 01151)\end{array}$ \\
\hline $\mathrm{TAC} * \#$ & Total accruals & $\begin{array}{l}\text { TAC is total accruals }=\text { net income }(w c 01751)-\text { cash from operations } \\
(w c 04860)\end{array}$ \\
\hline $\mathrm{REV}^{*}$ & Revenues & $R E V$ is net sales of revenues $(w c 01001)$ \\
\hline $\mathrm{REC}^{*}$ & Receivables & $R E C$ is receivables $(w c 02051)$ \\
\hline GROWTH & Growth deciles & $\begin{array}{l}\text { GROWTH is }(10 \%) \text { deciles of growth (change in net sales or revenues, } \\
w c 01001) \text { per year }\end{array}$ \\
\hline $\mathrm{CFO}$ & Cash from operations & $C F O$ is net cash flow - operating activities (wc04860) \\
\hline DCFO & $\begin{array}{l}\text { Dummy of cash from } \\
\text { operations }\end{array}$ & $\begin{array}{l}D C F O \text { is a dummy variable indicating with one whether the } \mathrm{CFO} \text { is } \\
\text { smaller than zero }\end{array}$ \\
\hline TA & Total assets & $T A$ is total assets $(w c 02999)$ \\
\hline
\end{tabular}




\section{Appendix 5 - 14: Definition of Variables (continued)}

\begin{tabular}{|c|c|c|}
\hline SHORT CUT & VARIABLE & DEFINITION \\
\hline \multicolumn{3}{|c|}{ Corporate Governance Measures (Source: proprietary data from Institutional Shareholder Services) } \\
\hline GOV & $\begin{array}{l}\text { Corporate governance } \\
\text { measure }\end{array}$ & $\begin{array}{l}G O V \text { is based on a self-constructed governance rating }\left(\mathrm{GOV}_{\text {ISS }}\right) \text { using ISS } \\
\text { CGQ raw data from } 2003 \text { to } 2007 \text {, and averaged (taking mean values from } \\
\text { GOV }_{\text {ISS }} \text { ) for our sample period (1998 to 2011) }\end{array}$ \\
\hline GOV_dummy & $\begin{array}{l}\text { Corporate governance } \\
\text { measure (dummy) }\end{array}$ & $\begin{array}{l}\text { GOV_dummy is a dummy variable taking the value of one if the firm's } \\
\text { governance measure (GOV) is above its mean value, and zero otherwise }\end{array}$ \\
\hline GOV_median & $\begin{array}{l}\text { Corporate governance } \\
\text { measure }\end{array}$ & $\begin{array}{l}\text { GOV_median is based on a self-constructed governance rating }\left(\mathrm{GOV}_{\text {ISS }}\right) \\
\text { using ISS CGQ raw data from ' } 03 \text { to ' } 07 \text {, and averaged (taking median } \\
\text { values from GOV } \\
\text { ISS }) \text { for our sample ( } 1998 \text { to } 2011)\end{array}$ \\
\hline GOV_Top $10 \%$ & $\begin{array}{l}\text { Corporate governance } \\
\text { measure (dummy) }\end{array}$ & $\begin{array}{l}\text { GOV_Top } 10 \% \text { is a dummy variable taking the value of one if the firm's } \\
\text { governance measure }(G O V) \text { belongs to the } 10^{\text {th }} \text { deciles, and zero otherwise }\end{array}$ \\
\hline GOV_pca & $\begin{array}{l}\text { Corporate governance } \\
\text { measure }\end{array}$ & $\begin{array}{l}\text { GOV_pca is a governance score based on Principal Component Analysis } \\
\text { (PCA) where the averaged (taking mean values) principal component - } \\
\text { estimated on six sub-scores which are based on UK firm-level ISS rating } \\
\text { data from the years } 2003 \text { to } 2007 \text { - with the highest eigenvalue is used to } \\
\text { proxy governance for the sample period (1998 to 2011) }\end{array}$ \\
\hline GOV_monitor & $\begin{array}{l}\text { Corporate governance } \\
\text { measure }\end{array}$ & $\begin{array}{l}G O V \text { monitor is a governance score based on the } \mathrm{GOV}_{\text {ISS }} \text { sub-categories: } \\
\text { board, audit, charter, anti-takeover, and progressive practice (it is based on } \\
\text { the individual firm data from } 2003 \text { to } 2007 \text { and is averaged for the M\&A } \\
\text { sample period) }\end{array}$ \\
\hline GOV_incentives & $\begin{array}{l}\text { Corporate governance } \\
\text { measure }\end{array}$ & $\begin{array}{l}\text { GOV incentives is a governance score based on the GOV } \text { ISS sub- } \\
\text { categories: compensation and managerial ownership (it is based on the } \\
\text { individual firm data from } 2003 \text { to } 2007 \text { and is averaged for the M\&A } \\
\text { sample period) }\end{array}$ \\
\hline $\mathrm{GOV}_{\text {ISS }}$ & $\begin{array}{l}\text { Corporate governance } \\
\text { measure }\end{array}$ & $\begin{array}{l}G O V_{I S S} \text { is a self-constructed governance score based on UK ISS CGQ raw } \\
\text { data from } 2003 \text { to } 2007 \text {. The UK CGQ rating relies on } 47 \text { criteria and is } \\
\text { organised into eight categories: board, audit, charter, anti-takeover } \\
\text { provisions, compensation, progressive practice, exc. ownership, and } \\
\text { education (see Hitz and Lehmann 2013). }\end{array}$ \\
\hline
\end{tabular}

Firm Control Variables (Source: Worldscope database)

\begin{tabular}{|c|c|c|}
\hline SIZE & Log of total assets & SIZE if the natural logarithm of total assets (EURO) $(x w c 02999 e)$ \\
\hline LEV & Leverage & $\begin{array}{l}L E V \text { is the accounting leverage as total debt }(w c 03255) \text { to total assets } \\
(w c 02999)\end{array}$ \\
\hline OWNER** & Log of ownership & Owner as ownership - closely held shares ( $w c 08021)$ \\
\hline BIG FIVE & $\begin{array}{l}\text { Audit quality by Big } \\
\text { Five Auditors }\end{array}$ & $\begin{array}{l}\text { BIG_FIVE is a dummy variable taking the value of one if the firm is } \\
\text { audited by PwC, KPMG, E\&Y, Deloitte, Arthur Andersen, or by one of } \\
\text { their predecessors, and zero otherwise (based on } w c 07800 \text { ) }\end{array}$ \\
\hline
\end{tabular}

M\&A Control Variables (Source: SDC Platinum \& Datastream database)

\begin{tabular}{lll}
\hline DEAL SIZE & Relative deal size & $\begin{array}{l}\text { Rel. Deal Size is deal size (transaction value) deflated by acquirers' } \\
\text { average fiscal year's market value of equity }(m v)\end{array}$ \\
$\begin{array}{l}\text { Ind Relatedness is a dummy variable taking the value of one if the four- } \\
\text { digit SIC code of the acquirer and the target is identical, and zero } \\
\text { otherwise }\end{array}$ \\
STOCK & Industrial relatedness & $\begin{array}{l}\text { Stock indicates the percentage of stock amount involved in the stock swap } \\
\text { deal financing }\end{array}$ \\
\hline
\end{tabular}


Appendix 5 - 14: Definition of Variables (continued)

\begin{tabular}{|c|c|c|}
\hline SHORT CUT & VARIABLE & DEFINITION \\
\hline \multicolumn{3}{|c|}{ Test Variables (Source: SDC Platinum database) } \\
\hline $\begin{array}{l}\text { TRANS-1 } \\
\text { (TRANS-2) } \\
\text { [TRANS-3] } \\
\text { TRANS0 } \\
\text { (TRANS+1) } \\
\text { (TRANS+2) } \\
\text { (TRANS+3) } \\
\end{array}$ & $\begin{array}{l}\text { Year-1 } \\
(\text { year-2) } \\
\text { [year-3] } \\
\text { Year0 } \\
\text { (year+1) } \\
{[\text { year+2] }} \\
\{\text { year+3 }\} \\
\end{array}$ & $\begin{array}{l}\text { TRANS-1 (TRANS-2) [TRANS-3] is a dummy variable taking the value of } \\
\text { one for the acquirer's first (second) [third] year with an earnings release } \\
\text { preceding the announcement of the stock swap, and zero otherwise } \\
\text { TRANSO (TRANS+1) [TRANS+2] \{TRANS+3\} is a dummy variable } \\
\text { taking the value of one in the year with the acquirer's first (second) [third] } \\
\text { \{fourth } \text { \} earnings release following the announcement of the stock swap, } \\
\text { and zero otherwise }\end{array}$ \\
\hline \multicolumn{3}{|c|}{ Robustness Section: Exclusion Restrictions \& Add. Variables (Source: Datastream \& Worldscope database) } \\
\hline $\begin{array}{l}\text { DPS } \\
\text { MILLS }\end{array}$ & $\begin{array}{l}\text { Dividend per share } \\
\text { Inverse Mills ratio }\end{array}$ & $\begin{array}{l}D P S \text { as dividends per share }(w c 05101) \\
M I L L S \text { is the inverse mills ratio from the first stage regression (selection } \\
\text { equation) included in the second stage regression of the two-stage } \\
\text { Heckman procedure }\end{array}$ \\
\hline BHAR & $\begin{array}{l}\text { Buy-and-hold abnormal } \\
\text { returns }\end{array}$ & $\begin{array}{l}\text { BHAR are based on the methodology proposed by Barber and Lyon (1997) } \\
\text { with matching firms based on size and book-to-market }\end{array}$ \\
\hline Tobin's Q & Tobin's Q & $\begin{array}{l}\text { Tobin's } Q \text { measures firm valuation by average fiscal year's market value } \\
(d w t a+m v-d w s e) \text { deflated by average fiscal year's total assets }(d w t a)\end{array}$ \\
\hline Growth3 & $\begin{array}{l}3 \text { years average change } \\
\text { in sales }\end{array}$ & Growth 3 is the past average three-years growth in net sales (wc01001) \\
\hline Growth & Change in sales & Growth is one-year growth in net sales (wc01001) \\
\hline ROA & Return on assets & $\begin{array}{l}\text { ROA is calculated as net income available to common shareholders } \\
(w c 01751) \text { divided by total assets ( } w c 02999)\end{array}$ \\
\hline Capital-Intensity & PPE to total assets & $\begin{array}{l}\text { Capital-Intensity is property, plant \& equipment (wc02501) to total assets } \\
\text { (wc02999) }\end{array}$ \\
\hline $\begin{array}{l}\text { Index } \\
\text { Membership }\end{array}$ & $\begin{array}{l}\text { Blue chip index } \\
\text { membership }\end{array}$ & $\begin{array}{l}\text { Index Membership is blue chip index membership based on FTSE100 } \\
(\text { wc05661) }\end{array}$ \\
\hline \multicolumn{3}{|c|}{ Robustness Section: Additional DAC Control Variables (Source: SDC Platinum \& Worldscope database) } \\
\hline M\&A Activity & $\begin{array}{l}\text { Stock swap M\&A } \\
\text { activity }\end{array}$ & $\begin{array}{l}M \& A \text { Activity measures the number of stock swap transactions per firm in } \\
\text { the period between } 1998 \text { and } 2011\end{array}$ \\
\hline Cross-border & Cross-border transaction & $\begin{array}{l}\text { Cross-border is a dummy variable taking the value of one if the stock } \\
\text { swap transactions take place as a cross-border transactions (with non-UK } \\
\text { targets), and zero otherwise }\end{array}$ \\
\hline Tender & Tender offer & $\begin{array}{l}\text { Tender is a dummy variable taking the value of one if the stock swap deal } \\
\text { is structured as a tender offer, and zero otherwise }\end{array}$ \\
\hline Completed & Deal completed & $\begin{array}{l}\text { Completed is a dummy variable taking the value of one if the stock swap } \\
\text { deal is completed, and zero otherwise }\end{array}$ \\
\hline Voting Rights & $\begin{array}{l}\text { Majority voting rights } \\
\text { transferred }\end{array}$ & $\begin{array}{l}\text { Majority voting rights is a dummy variable taking the value of one if the } \\
\text { majority voting rights of the target are transferred to the acquirer after the } \\
\text { deal is completed, and zero otherwise }\end{array}$ \\
\hline Deal Timing & $\begin{array}{l}\text { Strategic timing of the } \\
\text { deal announcement }\end{array}$ & $\begin{array}{l}\text { Deal Timing is measured as the difference between the deal announcement } \\
\text { date and the earnings release date (in months) }\end{array}$ \\
\hline Deal Duration & Deal duration & $\begin{array}{l}\text { Deal Duration is measured as the time length of the deal negotiation as the } \\
\text { difference between the deal announcement date and the deal completed } \\
\text { date (in months) }\end{array}$ \\
\hline
\end{tabular}


Appendix 5 - 14: Definition of Variables (continued)

\begin{tabular}{lll}
\hline SHORT CUT & VARIABLE & DEFINITION \\
\hline Robustness Section: Additional DAC Control Variables (Source: Worldscope \& IBES database)
\end{tabular}

* Winsorized by extreme percentiles (1\% level) to control for outliers.

\# Applying an alternative method following Botsari (2010) to calculate cash from operations (CFO) for our total accruals and working capital accruals measure does not alter our main results. Botsari $(2010$, p. 17) defines total $\underline{\text { accruals as } N I(w c 04001)}$ - CFO (wc04201+wc04831), and working capital accruals as NI (wc04001) - CFO (wc04201+wc04831) - Depreciation \& Amortization (wc04051).

** Since we expect decreasing marginal effects in additional blockholdings, we apply the log transformation on ownership concentration (e.g., Larcker et al., 2011, p. 439). 


\section{CONCLUSION}

\subsection{Summary of the Results}

Based on four empirical studies, this thesis addresses and extends two general literature streams; the stream on corporate governance advisory (e.g., Daines et al., 2010; Ertimur et al., 2013), and the stream on accrual-based earnings management and corporate governance quality (e.g., Klein, 2002; Larcker et al., 2007).

Pertaining to the former literature stream, the first objective of this thesis is to contrast the usefulness of governance advisory on capital markets (Study 1 and Study 2). Based on proxy voting recommendations issued by ISS for the German proxy season 2010, the thesis complements the discussion initiated by ESMA about the role of proxy advisors at European shareholder meetings and provides empirical evidence on the influence and method consistency of these advisors for a major European market (Study 1). In particular, the results suggest that "vote against" recommendations issued by ISS significantly correlate with $8.5 \%$ less supportive shareholder votes. This correlation is even more pronounced for firms with high free float, low voting turnout, and high ISS client base. However, in comparison to prior U.S. evidence, negative ISS voting recommendations affect in economic terms voting outcomes at a lower level. In addition, a second set of analyses suggests that ISS recommendations significantly correlate with ISS's commercially available corporate governance ratings. In contrast to recent U.S. findings, this result suggests an economically meaningful degree of method consistency with respect to ISS's employed governance perceptions. Overall, the findings highlight the potential influence as well as the consistency of ISS proxy voting recommendations at German shareholder meetings. Specifically, they suggest that - despite differences in the institutional set up between the U.S. and Germany proxy voting advisors seem to play an influential role at German shareholder meetings as well.

To glean additional insights into the usefulness of governance advisory, the thesis provides empirical evidence on the incremental usefulness of commercial governance ratings to investors (Study 2). Based on governance rating data provided by ISS for the UK and the German markets, it investigates in detail the incremental value created by the rating agency's activities of translating public and private information into commercial ratings. The findings indicate that, in line with prior work, commercial ratings are positively associated with firm 
value. However, isolating the incremental contribution of the rating agency, the thesis finds no additional explanatory power relative to a naïve rating that is constructed from the observable, publicly available inputs which ISS uses. This suggests that the rating agency does not create value in the process of converting public data into aggregated ratings. Overall, these findings put into question the incremental usefulness of the rating agencies' information processing activities.

Addressing both literature streams, the stream on governance advisory and the stream on earnings management and governance quality, the second objective of this thesis is to highlight the role of (non-financial) corporate governance analysts (Study 3). To that end, the thesis provides empirical evidence on the potential economic consequences of governance analyst coverage. Based on a quasi-natural experimental setting, that exploits an exogenous shock in the UK governance analyst coverage, this thesis finds that an increase in governance analyst coverage results in increasing analyst following, weakly in increasing free float, in improvements in firm-level corporate governance, and weakly in decreasing earnings management. These findings suggest that financial analysts, investors, and managers respond to changes in governance analyst coverage. Overall, the findings are consistent with the notion that governance analysts improve firm-level information environments and promote external monitoring to managers.

Drawing on research on corporate governance and earnings management, the third objective of this thesis is to highlight the setting specific-nature of the relationship between governance and earnings management (Study 4). In doing so, the thesis provides empirical evidence on the link between accruals manipulation and corporate governance in a specific setting, i.e., stock swap M\&A transactions. As accruals manipulation prior to share deals is potentially in the interests of the acquirer's invested shareholders, this setting offers an alternative perspective on the link between governance and earnings management. Specifically, it is plausible to assume that good governance negotiates the lowest target price for the acquirer's shareholders, and hence promotes income-increasing accruals manipulation prior to the deal negotiation. Using stock swap transactions with public acquirers originating from the UK between the years 1998 and 2011, the results contrast common claims that strong governance constrains accruals manipulation, and suggest that acquirers with strong governance engage more aggressively in income-increasing accruals manipulation than those with weak governance. This finding is consistent with the notion that corporate governance incentivizes managerial actions in the interests of firms' shareholders. Overall, this finding 
highlights the setting specific-nature of the earnings management and corporate governance relationship and thus suggests a possible explanation for the inconclusive evidence provided by prior literature on the link between governance and earnings management.

\subsection{Main Limitations of the Thesis}

In sum, the findings of this thesis - based on four empirical studies - shed light on essentially two points: (1) the economic role of corporate governance advisory as well as (2) potentially competing roles of corporate governance in shaping accrual-based earnings management. However, as outlined in the respective chapters and as summarized in Table $6-1$, the findings of this thesis are subject to several limitations. For one reason, research design issues might affect the thesis' findings. Boersch-Supan and Koeke (2002), for example, present a list of common problems of empirical corporate governance studies - e.g., endogeneity (i.e., reverse causality and omitted variables), sample selectivity, and measurement errors in the variables which likewise affect the thesis' findings at different levels.

For example, the studies' findings rely on the robustness of the empirical proxies used in the analyses. Previous accounting research discusses the construct validity of discretionary accruals (e.g., Collins et al., 2012) and corporate governance ratings (e.g., Larcker et al., 2007) and points out that prior findings are sensitive to the chosen measurement approach. As most earnings management studies, the third and fourth study of this thesis employ the Worldscope's standardized financial statement data to estimate discretionary accruals. As Young (2008, p. 674) notes, this might induce an estimation bias since the financial data underlying the accrual models contains both, the adjustments made by Worldscope analysts as well as accounting choices made by management. Even though the thesis challenges the findings with different discretionary accrual proxies and incorporates growth adjustments in the initial proxy (Collins et al., 2012), the robustness of the respective findings depends substantially on the perceived specification power of the discretionary accrual models. In addition, endogeneity (i.e., omitted variables) concerns might arise especially in the context of the first study on proxy voting recommendations and voting outcomes. As outlined in the respective section of the first study, a potential problem when analyzing the effects of these recommendations on voting outcomes is the distinction between correlation and causation. Correlation rather than causation occurs if proxy advisors simply anticipate shareholders' voting behavior due to a similar underlying information set. Although the thesis employs a variety of tests to address this issue, it cannot rule out that the results of the first study are 
driven by a mere correlation between proxy recommendations and shareholders' voting behavior. Stickiness concerns - especially in the context of the third and fourth study - might affect the robustness of the respective findings as well. Specifically, research design choices of the third study demand a rather low time-series stickiness in the four dependent variables (i.e., analyst following, free float, governance quality, and discretionary accruals). Put differently, the employed research design assumes that the respective outcome variables are able to respond in a timely manner to the exogenous shock in governance analyst coverage. In addition, the research design of the fourth study - especially the data constrains with respect to the employed governance proxy - requires a rather high relative stickiness in governance quality. In other words, the fourth study relies on the notion that the relative governance quality across firms in the cross section remains rather sticky over the sample period. Both stickiness assumptions, however, might be debatable in the light of prior research (e.g., Brown et al., 2011).

Table 6 - 1: Limitations and Avenues for Future Research

MAIn Limitations OF THE STUdY

\section{MAIN AVENUES FOR FUTURE} RESEARCH

Chapter 2: DOES PROXY VOTING ADVISORY MATTER IN A EUROPEAN CONTEXT? EVIDENCE FROM GERMAN ANNUAL MEETINGS (STUDY 1)

- Endogeneity (omitted variable) concerns: the study cannot distinguish between correlation and causation in the context of proxy recommendations and voting results

- Limited generalizability and data constrains: the study considers the role and influence of one particular proxy advisor (ISS) for a specific time frame (proxy season 2010) and market (Germany)
- Comparative differences in the role of (European vs. U.S.) proxy advisors at European shareholder meetings (e.g., Do local proxy advisors differ to non-local advisors in the way of incorporating institutional peculiarities?)

- Replication with alternative time frames and different European settings

- Interrelations of proxy advisors and other information intermediaries (e.g., Do financial analysts react on the release of proxy advisory reports?)

Chapter 3: THE USEFULNESS OF CORPORATE GOVERNANCE RATINGS - INSIGHTS FROM EUROPEAN SETTINGS (STUDY 2)

- Endogeneity concerns: governance quality, measured by the governance rating, is most likely endogenous - although applying IV regressions, the study cannot rule out that reverse causality as well as omitted variable problems affect the findings with respect to the relationship between governance and performance

- Limited generalizability and data constrains: the study considers the incremental value generation of one particular governance rating vendor (ISS) for a specific time frame (20032007) and markets (UK \& Germany)
- Comparative differences in how rating agencies create (incremental) value (e.g., Do rating agencies create value differently in the process of gathering, processing, and disseminating governance information to the market?)

- Usefulness of commercial corporate governance ratings in a different context (e.g., Do governance ratings serve as a mean to justify investment decisions by investment managers?) 
Table 6 - 1: Limitations and Avenues for Future Research (continued)

Chapter 4: DO CORPORATE GOVERNANCE ANALYSTS MATTER? EVIDENCE FROM A QUASI-NATURAL EXPERIMENT (STUDY 3)

- Concerns of construct validity: the validity of discretionary accruals is especially sensitive to the chosen measurement approach

- Stickiness concerns: research design demands a low time-series stickiness in the four outcome variable; analyst following, free float, governance quality, and discretionary accruals (this requires that the outcome variables are able to respond in a timely manner to the exogenous shock)

- Limited generalizability and data constrains: the study considers only one particular governance agency (ISS) for a specific time frame (20042006) and market (UK)

- Replication with alternative time frames and different institutional settings (however, identification might be a problem)

- First-time coverage effects in a cross-country setting (e.g., Do institutional features - like investor protection standards and the strength of alternative information intermediaries moderate the coverage effects of governance analysts?)

- Interrelation of governance analysts and other information intermediaries in more detail (e.g., Does the coverage by governance analysts affect financial analysts' forecasts properties?)

\section{Chapter 5: THE ROLE OF CORPORATE GOVERNANCE IN SHAPING ACCRUALS} MANIPULATION PRIOR TO ACQUISITIONS (STUDY 4)

- Concerns of construct validity: the validity of discretionary accruals is especially sensitive to the chosen measurement approach

- Stickiness concerns: research design demands a high relative stickiness in governance quality (this requires that the relative governance quality across firms in the cross-section remains sticky over the sample period)

- Limited generalizability and data constrains: the study is based on a rather small sample and considers only one particular market (UK)
- Interrelation of different governance mechanisms (e.g., incentive vs. monitoring mechanisms) and different earnings management tools prior to stock swap deals (e.g., accrual-based, formal, and real earnings management activities)

- Replication with different institutional settings (e.g., Do institutional features - like investor protection standards - moderate the earnings management mix and the respective governance role?)

- Role of governance in shaping earnings management in a setting with no explicit benefits for current or future shareholders (e.g., Does corporate governance constrains income-decreasing earnings management prior to management buyouts?)

\subsection{Avenues for Future Research}

The thesis' findings create various research opportunities. As reflected in Table 6 - 1, future research may extend the first and the second study of the thesis by investigating the comparative differences in how rating agencies create value or proxy advisors affect voting outcomes. Complementing the fourth study, future research might examine the interrelation of different governance mechanisms and different earnings management activities prior to stock swap deals. It is plausible to assume that the relationship between governance and earnings management is determined not only by the setting itself but also by the plurality of governance mechanisms (e.g., incentive vs. control mechanisms or external vs. internal mechanisms) and the diversity of earnings management tools (accrual-based, formal, or real 
earnings management). Another path would be to challenge the robustness of the findings by conducting the analyses of the studies for alternative time frames and different institutional settings. With respect to the third study, it is plausible to assume, for example, that institutional features, like enforcement strength or investor protection standards, affect the economic role of governance analysts and the respective coverage effects. In addition, future research might highlight in more detail the interrelation of governance advisory firms and other information intermediaries. With respect to the first study, it would be worth to examine whether financial analysts react to the release of proxy advisory reports (e.g., whether forecast revisions, for example, increase around the release of proxy voting reports). Prior literature, so far, only provides evidence that the capital market reacts on the release of proxy reports (e.g., Ertimur et al., 2013), without examining, however, potential channels which might facilitate the information flow to the market. Overall, the growing literature on the interrelation of corporate governance, information intermediation, and earnings management offers a variety of fruitful avenues for future research.

"If applied econometrics were easy, theorists would do it. But it's not as hard as the dense pages of Econometrica might lead you to believe. Carefully applied to coherent causal questions, regression and 2SLS almost make sense. Your standard errors probably won't be quite right, but they rarely are.

Avoid embarrassment by being your own best skeptic, and especially, DON'T PANIC!" (Angrist and Pischke, 2008, p. 327) 


\section{REFERENCES}

Adam, T. / Goyal, V. (2008): The investment opportunity set and its proxy variables, in: Journal of Financial Research, Vol. 31 No. 1 (2008), pp. 41-63.

Aggarwal, R. / Erel, I. / Stulz, R. / Williamson, R. (2009): Differences in Governance Practices between U.S. and Foreign Firms: Measurement, Causes, and Consequences, in: The Review of Financial Studies, Vol. 22 No. 8 (2009), pp. 3131-3169.

Aggarwal, R. / Erel, I. / Ferreira, M. / Matos, P. (2011): Does Governance travel around the world? Evidence from Institutional Investors, in: Journal of Financial Economics, Vol. 100 No. 1 (2011), pp. 154-181.

Ahrens, T. / Filatotchev, I. / Thomson, S. (2009): The research frontier in corporate governance, in: Journal of Management and Governance, (2009), pp. 1-15.

AktG (2009): Aktiengesetz, 2009.

Amar, W. B. / Boujenoui, A. / Francoeur, C. (2011): CEO Attributes, Board Composition, and Acquirer Value Creation: A Canadian Study, in: Canadian Journal of Administrative Sciences, No. 28 (2011), pp. 480-492.

Ammann, M. / Oesch, D. / Schmid, M. (2011): Product Market Competition, Corporate Governance, and Firm Value: Evidence from the EU Area, in: European Financial Management (online first), (2011), pp. 1-18.

Angrist, J. D. / Pischke, J. S. (2008): Mostly Harmless Econometrics. 2008.

Asare, K. N. / Abdolmohammadi, M. / Hunton, J. E. (2011): The Influence of Corporate Governance Ratings on Buy-Side Analysts' Earnings Forecast Certainty: Evidence from the United States and the United Kingdom, in: Behavioral Research in Accounting, Vol. 23 No. 2 (2011), pp. 1-25.

Baik, B. / Kang, J. / Morton, R. (2007): Earnings Management in Takeovers of Privately Held Targets, SSRN Working Paper, Seoul National University et al., 2007.

Baik, B. / Kang, J. / Morton, R. (2010): Why are analysts less likely to follow firms with high managerial ownership? In: Journal of Accounting, Auditing \& Finance, Vol. 25 No. 2 (2010), pp. 171-200.

Ball, R. / Shivakumar, L. (2006): The Role of Accruals in Asymmetrically Timely Gain and Loss Recognition, in: Journal of Accounting Research, Vol. 44 No. 2 (2006), pp. $207-$ 242.

Ball, R. / Shivakumar, L. (2008): Earnings Quality of Initial Public Offerings, in: Journal of Accounting and Economics, Vol. 45 (2008), pp. 324-349.

Balling, M. / Holm, C. / Poulsen, T. (2005): Corporate governance ratings as a means to reduce asymmetric information, Aarhus School of Business, Working Paper, 2005.

Barber, B. M. / Lyon, J. D. (1997): Detecting long-run abnormal stock returns: The empirical power and specification of test statistics, in: Journal of Financial Economics, Vol. 43 (1997), pp. 341-372.

Barth, M. / Kasznik, R. / McNichols, M. (2001): Analyst Coverage and Intangible Assets, in: Journal of Accounting Research, Vol. 39 No. 1 (2001), pp. 1-35.

Bauer, R. / Guenster, N. / Otten, R. (2004): Empirical evidence on corporate governance in 
Europe: The effect on stock returns, firm value, and performance, in: Journal of Asset Management, Vol. 5 No. 2 (2004), pp. 91-104.

Bauer, R. / Frijns, B. / Otten, R. / Tourani-Rad, A. (2008): The impact of corporate governance on corporate performance: Evidence from Japan, in: Pacific-Basin Finance Journal, Vol. 16 No. 3 (2008), pp. 236-251.

Baum, C. F. / Schaffer, M. E. / Stillman, S. (2007): Enhanced routines for instrumental variables / generalized method of moments estimation and testing, in: The Stata Journal, Vol. 7 No. 4 (2007), pp. 465-506.

Baums, T. / Scott, K. (2005): Taking Shareholder Protection Seriously? Corporate Governance in the United States and Germany, in: The American Journal of Comparative Law, Vol. 53 (2005), pp. 31-75.

Bebchuk, L. A. / Hamadini, A. (2009): The elusive quest for global governance standards, in: University of Pennsylvania Law Review, Vol. 157 No. 5 (2009), pp. 1263-1317.

Bebchuk, L. / Cohen, A. / Ferrel, A. (2009): What matters in Corporate Governance? In: The Review of Financial Studies, Vol. 22 No. 2 (2009), pp. 783-827.

Bebchuk, L. A. / Cohen, A. / Wang, C. (2013): Learning and the Disappearing Association between Governance and Returns, in: Journal of Financial Economics, Vol. 108 (2013), pp. 323-348.

Bebchuk, L. A. / Weisbach, M. (2010): The State of Corporate Governance Research, in: The Review of Financial Studies, Vol. 23 No. 3 (2010), pp. 939-961.

Becht, M. / Jenkinson, T. / Mayer, C. (2005): Corporate Governance: An Assessment, in: Oxford Review of Economic Policy, Vol. 21 No. 2 (2005), pp. 155-163.

Beckley, C. / Perrett, J. / et al., (2005): FTSE ISS Corporate Governance Rating and Index Series - Measuring the Impact of Corporate Governance on Global Portfolios, FTSE ISS CGI Series Research Report, 2005.

Beiner, S. / Drobetz, W. / Schmid, M. / Zimmermann, H. (2006): An Integrated Framework of Corporate Governance and Firm Valuation, in: European Financial Management, Vol. 12 No. 2 (2006), pp. 249-283.

Belinfanti, T. C. (2009): The Proxy Advisory and Corporate Governance Industry: The Case of Increased Oversight and Control, in: Stanford Journal of Law Business \& Finance, Vol. 14 No. 2 (2009), pp. 384-439.

Bethel, J. E. / Gillan, S. L. (2002): The impact of the institutional and regulatory environment on shareholder voting, in: Financial Management, Vol. 31 No. 4 (2002), pp. 29-54.

Beyer, A. / Cohen, D. A. / Lys, T. Z. / Walther, B. R. (2010): The financial reporting environment: Review of the recent literature, in: Journal of Accounting and Economics, Vol. 50 (2010), pp. 296-343.

Bhagat, S. / Bolton, B. (2008): Corporate governance and firm performance, in: Journal of Corporate Finance, Vol. 14 No. 3 (2008), pp. 257-273.

Bhat, G. / Hope, O. / Kang, T. (2006): Does corporate governance transparency affect the accuracy of analyst forecasts? In: Accounting and Finance, Vol. 46 (2006), pp. 715732.

Bhushan, R. (1989): Firm Characteristics and Analyst Following, in: Journal of Accounting and Economics, Vol. 11 (1989), pp. 255-274. 
Boersch-Supan, A. / Koeke, J. (2002): An Applied Econometricians' View of Empirical Corporate Governance Studies, in: German Economic Review, Vol. 3 No. 3 (2002), pp. 295-326.

Bolton, P. / Scheinkman, J. / Xiong, W. (2005): Pay for Short-Term Performance: Executive Compensation in Speculative Markets, Working Paper, Princeton University, 2005.

Botsari, A. / Meeks, G. (2008): Do Acquirers Manage Earnings Prior to a Share for Share Bid? In: Journal of Business Finance \& Accounting, Vol. 35 No. 5-6 (2008), pp. 633670 .

Botsari, A. (2010): Earnings Management and Market Efficiency: Re-examining the PostMerger Performance Puzzle, University of Piraeus, EFMA Conference Paper, 2010.

Bowen, R. / Rajgopal, S. / Venkatachalam, M. (2008): Accounting Discretion, Corporate Governance, and Firm Performance, in: Contemporary Accounting Research, Vol. 25 No. 2 (2008), pp. 351-405.

BPP Group Consultation (2013): Public Consultation on Best Practice Principles for Governance Research Providers, 2013.

Brown, L. D. / Caylor, M. L. (2006): Corporate governance and firm valuation, in: Journal of Accounting and Public Policy, Vol. 25 No. 4 (2006), pp. 409-434.

Brown, L. D. / Caylor, M. L. (2009): Corporate governance and firm operating performance, in: Review of Quantitative Finance and Accounting, Vol. 32 No. 2 (2009), pp. 129-144.

Brown, P. / Beekes, W. / Verhoeven, P. (2011): Corporate Governance, accounting and finance: A review, in: Accounting \& Finance, Vol. 51 No. 1 (2011), pp. 96-172.

Burkart, M. / Panunzi, F. (2006): Takeovers, Stockholm Business School, ECGI Finance Working Paper No. 118/2006, 2006.

Bushman, R. M. / Piotroski, J. D. / Smith, A. J. (2004): What Determines Corporate Transparency? In: Journal of Accounting Research, Vol. 42 No. 2 (2004), pp. 207-252.

Byard, D. / Li, Y. / Weintrop, J. (2006): Corporate governance and the quality of financial analysts' information, in: Journal of Accounting and Public Policy, Vol. 25 (2006), pp. 609-625.

Cai, J. / Garner, J. / Walking, R. (2009): Electing Directors, in: Journal of Finance, Vol. 64 No. 5 (2009), pp. 2389-2421.

Capron, L. / Shen, J. C. (2007): Acquisitions of private vs. public firms: Private information, target selection, and acquirer returns, in: Strategic Management Journal, Vol. 28 No. 9 (2007), pp. 891-911.

CBM PwC (2008): The Corporate Board Member/PricewaterhouseCoopers Survey 2008 What Directors Think, 2008.

CBM PwC (2009): The Corporate Board Member/PricewaterhouseCoopers Survey 2009 What Directors Think, 2009.

Center on Executive Compensation (2011): A Call for Change in the Proxy Advisory Industry Status Quo: The Case for Greater Accountability and Oversight? White Paper, 2011.

Chen, T. / Harford, J. / Lin, C. (2013): Do Analysts matter for governance? Evidence from natural experiments, SSRN Working Paper, 2013.

Cheng, Y. / Liu, M. H. / Qian, J. (2006): Buy-Side Analysts, Sell-Side Analysts, and Investment Decisions of Money Managers, in: Journal of Financial and Quantitative 
Analysis, Vol. 41 No. 1 (2006), pp. 51-83.

Choi, S. / Fisch, J. / Kahan, M. (2009): Director Elections and the Role of Proxy Advisors, in: Southern California Law Review, Vol. 82 (2009), pp. 649-702.

Choi, S. / Fisch, J. / Kahan, M. (2010): The Power of Proxy Advisors: Myth or Reality? In: Emory Law Journal, Vol. 59 (2010), pp. 869-918.

Christie, A. / Zimmerman, J. (1994): Efficient and Opportunistic Choices of Accounting Procedures: Corporate Control Contests, in: The Accounting Review, Vol. 69 No. 4 (1994), pp. 539-566.

Chung, R. / Firth, M. / Kim, J. (2002): Institutional monitoring and opportunistic earnings management, in: Journal of Corporate Finance, Vol. 8 No. 1 (2002), pp. 29-48.

Cohen, D. A. / Zarowin, P. (2010): Accrual-based and real earnings management activities around seasoned equity offerings, in: Journal of Accounting and Economics, Vol. 50 (2010), p. 2-19.

Coffin, W. F. / Collinson, M. (2005): The Rise of Corporate Governance Ratings, CCG IR Strategy Series Paper, 2005.

Cohen, D. A. / Dey, A. / Lys, T. Z. (2008): Real and Accrual-based Earnings Management in the Pre- and Post-Sarbanes Oxley Periods, in: The Accounting Review, Vol. 83 No. 3 (2008), pp. 757-787.

Collins, D. W. / Pungaliya, R. S. / Vijh, A. M. (2012): The Effect of Firms Growth and Model Specification Choices on Tests of Earnings Management, The University of Iowa, SSRN Working Paper, 2012.

Core, J. E. / Larcker, D. F. (2002): Performance consequences of mandatory increases in executive stock ownership, in: Journal of Financial Economics, Vol. 64 No. 3 (2002), pp. 317-340.

Cormier, D. / Martinez, I. (2006): The association between management earnings forecasts, earnings management, and stock market valuation: Evidence from French IPOs, in: The International Journal of Accounting, Vol. 41 No. 3 (2006), pp. 209-236.

Cromme, G. (2005): Corporate Governance in Germany and the German Corporate Governance Code, in: Corporate Governance: An International Review, Vol. 13 No. 3 (2005), pp. 362-367.

Cziraki, P. / Renneboog, L. / Szilagyi, P. (2010): Shareholder Activism through Proxy Proposals: The European Perspective, in: European Financial Management, Vol. 16 No. 5 (2010), pp. 738-777.

Daines, R. (2001): Does Delaware law improve firm value? In: Journal of Financial Economics, Vol. 62 (2001), pp. 525-558.

Daines, R. / Gow, I. / Larcker, D. (2008): Rating the Raters: Are Governance Ratings Any Good? Stanford University, Working Paper, 2008.

Daines, R. M. / Gow, I. D. / Larcker, D. F. (2010): Rating the ratings: How good are commercial governance ratings? In: Journal of Financial Economics, Vol. 98 No. 3 (2010), pp. 439-461.

Dalton, D. R. / Daily, C. M. / Ellstrand, A. E. / Johnson, J. L. (1998): Meta-Analytic Reviews of Board Composition, Leadership Structure, and Financial Performance, in: Strategic Management Journal, Vol. 19 No. 3 (1998), pp. 269-290. 
Dalton, D. R. / Daily, C. M. / Certo, S. T. / Roengpitya, R. (2003): Meta-analysis of financial performance and equity: Fusion or confusion? In: Academy of Management Journal, Vol. 46 No. 1 (2003), pp. 13-26.

Daske, H. / Hail, L. / Leuz, C. / Verdi, R. (2008): Mandatory IFRS Reporting Around the World: Early Evidence on the Economic Consequences, in: Journal of Accounting Research, Vol. 46 No. 5 (2008), pp. 1085-1142.

Davidson, R. / MacKinnon, J. (1993): Estimation and inference in econometrics. New York 1993.

Davidson, R. / Goodwin-Stewart, J. / Kent, P. (2005): Internal governance structures and earnings management, in: Accounting and Finance, Vol. 45 No. 2 (2005), pp. 241-267.

De Andres, P. / Azofra, V. / Lopez, F. (2005): Corporate Boards in OECD Countries: size, composition, functioning and effectiveness, in: Corporate Governance: An International Review, Vol. 13 No. 2 (2005), pp. 197-210.

De Fraja, G. / Oliveira, T. / Zanchi, L. (2010): Must try harder: Evaluating the Role of Effort in Educational Attainment, in: Review of Economics and Statistics, Vol. 92 No. 3 (2010), pp. 577-597.

De Franco, G. / Vasvari, F. P. / Wittenberg-Moerman, R. (2009): The Informational Role of Bond Analysts, in: Journal of Accounting Research, Vol. 47 No. 5 (2009), pp. 12011248.

Dechow, P. / Sloan, R. / Sweeney, A. (1996): Causes and Consequences of Earnings Manipulation: An Analysis of Firms Subject to Enforcement Actions by the SEC, in: Contemporary Accounting Research, Vol. 13 No. 1 (1996), pp. 1-36.

Dechow, P. / Ge, W. / Schrand, C. (2010): Understanding earnings quality: A review of the proxies, their determinants and their consequences, in: Journal of Accounting and Economics, Vol. 50 No. 2-3 (2010), pp. 344-401.

DeFond, M. L. / Jiambalvo, J. (1994): Debt covenant violation and manipulation of accruals, in: Journal of Accounting and Economics, Vol. 17 No. 1-2 (1994), pp. 154-176.

Degeorge, F. / Ding, Y. / Jeanjean, T. / Stolowy, H. (2013a): Analyst coverage, earnings management and financial development: An international study, in: Journal of Accounting and Public Policy, Vol. 32 (2013), pp. 1-25.

Degeorge, F. / Derrien, F. / Kecskes, A. / Michenaud, S. (2013b): Do Analysts' Preferences Affect Corporate Policies? SSRN Working Paper, 2013.

Derwall, J. / Verwijmeren, P. (2007): Corporate Governance and the Cost of Equity Capital: Evidence from GMI's Governance Rating, RSM Erasmus University, Working Paper, 2007.

Drobetz, W. (2002): Corporate Governance - Legal Fiction or Economic Reality, in: Financial Markets and Portfolio Management, Vol. 16 No. 4 (2002), pp. 431-439.

Drobetz, W. / Schillhofer, A. / Zimmermann, H. (2004): Corporate Governance and Expected Stock Returns: Evidence from Germany, in: European Financial Management, Vol. 10 No. 2 (2004), pp. 267-293.

Dubois, E. (2012): Shareholders' General Meetings and the Role of Proxy Advisors in France and Japan, in: Kyushu Journal of International Legal Studies, No. 4 (2012), pp. 56-106.

Epps, R. W. / Cereola, S. J. (2008): Do institutional shareholder services (ISS) corporate 
governance ratings reflect a company's operating performance? In: Critical Perspectives on Accounting, Vol. 19 No. 8 (2008), pp. 1135-1148.

Erickson, M. / Wang, S. (1999): Earnings management by acquiring firms in stock for stock mergers, in: Journal of Accounting and Economics, Vol. 27 No. 2 (1999), pp. 149-176.

Ertimur, Y. / Muslu, V. / Ferri, F. (2009): Shareholder Activism and CEO Pay, SSRN Working Paper (forthcoming Review of Financial Studies), 2009.

Ertimur, Y. / Ferri, F. / Maber, D. (2011): Reputation Penalties for Poor Monitoring of Executive Pay: Evidence from Option Backdating, SSRN Working Paper, (forthcoming JFE), 2011.

Ertimur, Y. / Ferri, F. / Oesch, D. (2013): Shareholder Votes and Proxy Advisors: Evidence from Say on Pay, SSRN Working Paper, Columbia University (forthcoming JAR), 2013.

Ertugrul, M. / Hegde, S. (2009): Corporate Governance Ratings and Firm Performance, in: Financial Management, Vol. 38 No. 1 (2009), pp. 139-160.

European Commission (2011): Green Paper - The EU corporate governance framework, COM 2011/164 final, 2011.

European Securities and Markets Authority (ESMA) (2012): An Overview of the Proxy Advisory Industry. Considerations on Possible Policy Options, ESMA/2012/212, 2012.

European Securities and Markets Authority (ESMA) (2013): Final Report: Feedback statement on the consultation regarding the role of proxy advisory industry, ESMA/2013/84, 2013.

Farber, D. B. (2005): Restoring Trust after Fraud: Does Corporate Governance Matter? in: The Accounting Review, Vol. 80 No. 2 (2005), pp. 539-561.

Francis, J. / LaFond, R. / Olsson, P. M. / Schipper, K. (2004): Costs of Equity and Earnings Attributes, in: The Accounting Review, Vol. 79 No. 4 (2004), pp. 967-1010.

FTSE ISS CGI (2005): FTSE ISS Corporate Governance Index Series, Presentation, April 2005.

Garcia Lara, J. M. / Garcia Osma, B. / Penalva, F. (2012): Accounting conservatism and the limits to earnings management, SSRN Working Paper, Universidad Carlos III de Madrid, 2012.

Garcia-Meca, E. / Sanchez-Ballesta, J. P. (2009): Corporate Governance and Earnings Management: A Meta-Analysis, in: Corporate Governance: An International Review, Vol. 17 No. 5 (2009), pp. 594-610.

Gassen, J. (2013): Causal Inference in Empirical Archival Financial Accounting Research, SSRN Working Paper (Accounting, Organizations and Society, forthcoming), 2013.

Goergen, M. / Manjon, M. C. / Renneboog, L. (2008): Is the German system of corporate governance converging towards the Anglo-American model? in: Journal of Management and Governance, Vol. 12 No. 1 (2008), pp. 37-71.

Gompers, P. A. / Ishii, J. L. / Metrick, A. (2003): Corporate Governance and Equity Prices, in: Quarterly Journal of Economics, Vol. 118 No. 1 (2003), pp. 107-155.

Goncharov, I. / Jacob, M. (2012): Accrual Accounting and Tax Revenues, WHU - Otto Beisheim School of Management, SSRN Working Paper, 2012.

Gow, I. D. / Ormazabal, G. / Taylor Daniel J, (2010): Correcting for Cross-Sectional and Time-Series Dependence in Accounting Research, in: The Accounting Review, Vol. 85 
No. 2 (2010), pp. 483-512.

Gujarati, D. N. (2003): Basic Econometrics. 4. Edition, Boston 2003.

Hart, O. (1995): Corporate Governance: Some Theory and Implications, in: The Economic Journal, Vol. 105 No. 430 (1995), pp. 678-689.

Healy, P. (1985): The Effect of Bonus Schemes on Accounting Decisions, in: Journal of Accounting and Economics, Vol. 7 No. 1-3 (1985), pp. 85-107.

Healy, P. M. / Wahlen, J. M. (1999): A Review of the Earnings Management Literature and its Implication for Standard Setting, in: Accounting Horizons, Vol. 13 No. 4 (1999), pp. 365-383.

Healy, P. M. / Palepu, K. (2002): Governance and Intermediation Problems in Capital Markets: Evidence from the Fall of Enron, Harvard Business School, SSRN Working Paper, 2002.

Heron, R. / Lie, E. (2002): Operating Performance and the Method of Payment in Takeovers, in: Journal of Financial and Quantitative Analysis, Vol. 37 No. 1 (2002), pp. 137-155.

Hitz, J. M. / Werner, J. R. (2012): Why do Firms Resist Individualized Disclosure of Management Remuneration? University of Goettingen, Working Paper, 2012.

Hitz, J. / Löw, P. / Solka, M. (2013): Determinants of audit delay in a mandatory IFRS setting, in: Die Betriebswirtschaft, Vol. 73 No. 4 (2013), pp. 293-305.

Hitz, J. M. / Lehmann, N. (2013): The usefulness of corporate governance ratings - Insights from European settings, SSRN Working Paper, 2013.

Hopt, K. J. (2011): Comparative Corporate Governance: The State of the Art and International Regulation, in: American Journal of Comparative Law, Vol. 59 (2011), pp. 1-74.

Hribar, P. / Collins, D. W. (2002): Errors in Estimating Accruals: Implication for Empirical Research, in: Journal of Accounting Research, Vol. 40 No. 1 (2002), pp. 105-134.

Irani, R. / Oesch, D. (2013): Monitoring and corporate disclosure: Evidence from a natural experiment, in: Journal of Financial Economics, Vol. 109 (2013), pp. 398-418.

ISS (2007): ISS US Corporate Governance Policy 2007 Updates, 2007.

ISS (2010): ISS 2010 Voting Results Report: Europe, 2010.

ISS (2011): Institutionelle Aktionärsvertreter - die (un)bekannte Macht? Presentation by Thomas von Oehsen, stocks \& standards-Workshop Deutsche Börse, Eschborn, September, 2011.

IVOX (2012): IVOX - Presentation, https://www.ivox-europe.com/index.php/downloads.html, 2012 (last accessed June 30, 2014).

Jensen, M. C. / Meckling, W. H. (1976): Theory of the Firm: Managerial Behavior, Agency Costs and Ownership Structure, in: Journal of Financial Economics, Vol. 3 No. 4 (1976), pp. 305-360.

Jiraporn, P. / Kim, Y. A. / Kim, J. C. (2011): Dividend Payouts and Corporate Governance Quality: An Empirical Investigation, in: The Financial Review, Vol. 46 (2011), pp. 251279.

Jiraporn, P. / Chintrakarn, P. / Kim, Y. S. (2012a): Analyst following, staggered boards, and managerial entrenchment, in: Journal of Banking \& Finance, Vol. 36 (2012), pp. 3091- 
3100.

Jiraporn, P. / Liu, Y. / Kim, Y. S. (2012b): How do powerful CEOs affect analyst coverage? In: European Financial Management (forthcoming), (2012), pp. 1-25.

Kang, J. / Stulz, R. M. (2000): Do Banking Shocks affect borrowing Firm Performance? An Analysis of the Japanese Experience, in: Journal of Business, Vol. 73 No. 1 (2000), pp. $1-23$.

Klapper, L. F. / Love, I. (2004): Corporate governance, investor protection, and performance in emerging markets, in: Journal of Corporate Finance, Vol. 10 No. 5 (2004), pp. 703 728.

Klein, A. (2002): Audit committee, board of director characteristics, and earnings management, in: Journal of Accounting and Economics, Vol. 33 No. 3 (2002), pp. 375400 .

Koehn, D. / Ueng, J. (2005): Evaluating the Evaluators: Should Investors Trust Corporate Governance Metrics Ratings? in: Journal of Management and Governance, Vol. 9 No. 2 (2005), pp. 111-128.

Koehn, D. / Ueng, J. (2007): Corporate Governance Ratings: General Concerns and Specific Problems in the European Context, in: Journal of Corporate Ownership \& Control, Vol. 5 No. 1 (2007), pp. 58-65.

Koh, P. / Laplante, S. K. / Tong, Y. H. (2007): Accountability and value enhancement roles of corporate governance, in: Accounting and Finance, Vol. 47 No. 2 (2007), pp. 305-333.

Kothari, S. P. / Leone, A. / Wasley, C. (2005): Performance matched discretionary accrual measures, in: Journal of Accounting and Economics, Vol. 39 No. 1 (2005), pp. 163-197.

Kothari, S. P. / Warner, J. B. (2006): Econometrics of Event Studies, Tuck School of Business at Dartmouth, Working Paper, 2006.

La Porta, R. / Lopez-de-Silanes, F. / Shleifer, A. (1998): Law and Finance, in: Journal of Political Economy, Vol. 106 No. 6 (1998), pp. 1113-1152.

Lang, L. / Stulz, R. (1994): Tobin's Q, corporate diversification, and firm performance, in: Journal of Political Economy, Vol. 102 No. 6 (1994), pp. 1248-1281.

Lang, M. H. / Lins, K. V. / Miller, D. P. (2004): Concentrated Control, Analyst Following, and Valuation: Do Analysts Matter Most When Investors are Protected Least? in: Journal of Accounting Research, Vol. 42 No. 3 (2004), pp. 589-623.

Larcker, D. F. / Richardson, S. A. / Tuna, I. (2007): Corporate Governance, Accounting Outcomes, and Organizational Performance, in: The Accounting Review, Vol. 82 No. 4 (2007), pp. 963-1008.

Larcker, D. F. / Rusticus, T. O. (2010): On the use of instrumental variables in accounting research, in: Journal of Accounting and Economics, Vol. 49 No. 3 (2010), pp. 186-205.

Larcker, D. F. / Tayan, B. (2011): Corporate Governance Matters - A closer look at organizational choices and their consequences. New Jersey 2011.

Larcker, D. F. / Ormazabal, G. / Taylor, D. J. (2011): The market reaction to corporate governance regulation, in: Journal of Financial Economics, Vol. 101 (2011), pp. 431448.

Larcker, D. F. / McCall, A. L. / Ormazabal, G. (2013): Proxy advisory firms and stock option repricing, in: Journal of Accounting and Economics, Vol. 56 (2013), pp. 149-169. 
Lehn, K. / Patro, S. / Zhao, M. (2006): Governance Indices and Valuation: Which Causes Which? Working Paper, University of Pittsburgh (forthcoming Journal of Corporate Finance 2007), 2006.

Lennox, C. / Pittman, J. A. (2010): Big Five Audits and Accounting Fraud, in: Contemporary Accounting Research, Vol. 27 No. 1 (2010), pp. 209-247.

Lennox, C. S. / Francis, J. R. / Wang, Z. (2012): Selection Models in Accounting Research, in: The Accounting Review, Vol. 87 No. 2 (2012), pp. 589-616.

Lobo, G. J. / Song, M. / Stanford, M. (2012): Accruals quality and analyst coverage, in: Journal of Banking \& Finance, Vol. 36 (2012), pp. 497-508.

Louis, H. (2004): Earnings management and the market performance of acquiring firms, in: Journal of Financial Economics, Vol. 74 No. 1 (2004), pp. 121-148.

Lyon, J. / Barber, B. / Tsai, C. (1999): Improved Methods for Tests of Long-Run Abnormal Stock Returns, in: The Journal of Finance, Vol. 54 No. 1 (1999), pp. 165-201.

Lys, T. / Naughton, J. / Wang, C. (2012): Signaling through corporate accountability reporting, Working Paper, 2012.

Mackenzie, C. / Rees, W. / Rodionova, (2013): Do responsible investment indices improve corporate social responsibility? FTSE4Good's impact on environmental management, in: Corporate Governance: An International Review, Vol. 21 No. 5 (2013), pp. 495512.

Marketwire (2010): The Corporate Library and Governance Metrics International Agree to Merge, 22/07/2010, http://www.marketwire.com/press-release/the-corporate-libraryand-governancemetrics-international-agree-to-merge-1294553.htm, 2010 (last accessed June 30, 2014).

McConnell, J. / Servaes, H. (1990): Additional evidence on equity ownership and corporate value, in: Journal of Financial Economics, Vol. 27 (1990), pp. 595-612.

Mitton, T. (2002): A cross-firm analysis of the impact of corporate governance on the East Asian financial crisis, in: Journal of Financial Economics, Vol. 64 No. 2 (2002), pp. 215-241.

Mohanram, P. S. / Sunder, S. V. (2006): How Has Regulation FD Affected the Operations of Financial Analysts? in: Contemporary Accounting Research, Vol. 23 No. 2 (2006), pp. 491-525.

Morck, R. / Shleifer, A. / Vishny, R. (1988): Management Ownership and Market Valuation An Empirical Analysis, in: Journal of Financial Economics, Vol. 20 (1988), pp. 293315.

Mroz, T. A. (1987): The sensitivity of an empirical model of married women's hours of work to economic and statistical assumptions, in: Econometrica, Vol. 55 No. 4 (1987), pp. 765-799.

O'Brien, P. C. / Bhushan, R. (1990): Analyst Following and Institutional Ownership, in: Journal of Accounting Research, Vol. 28 (1990), pp. 55-76.

Orens, R. / Lybaert, N. (2010): Determinants of sell-side financial analysts' use of nonfinancial information, in: Accounting and Business Research, Vol. 40 No. 1 (2010), pp. $39-53$.

Peasnell, K. / Pope, P. / Young, S. (2000): Detecting earnings management using cross- 
sectional abnormal accruals models, in: Accounting \& Business Research, Vol. 30 No. 4 (2000), pp. 313-326.

Petersen, M. A. (2009): Estimating Standard Errors in Finance Panel Data Sets: Comparing Approaches, in: Review of Financial Studies, Vol. 22 No. 1 (2009), pp. 435-480.

Pungaliya, R. S. / Vijh, A. M. (2009): Do Acquiring Firms Manage Earnings? SSRN Working Paper, University of Iowa, 2009.

Renders, A. / Vandenbogaerde, S. (2008): Corporate Governance and Earnings Management: Evidence from Europe, in: Review of Business and Economics, Vol. 53 No. 3 (2008), pp. 263-287.

Renders, A. / Gaeremynck, A. / Sercu, P. (2010): Corporate-Governance Ratings and Company Performance: A Cross-European Study, in: Corporate Governance: An International Review, Vol. 18 No. 2 (2010), pp. 87-106.

Richter, A. / Weiss, C. (2013): Determinants of ownership concentration in public firms: The importance of firm-, industry- and country-level factors, in: International Review of Law and Economics, Vol. 33 (2013), pp. 1-14.

RiskMetrics Group (2007): Corporate Governance Quotient: Indicator Definitions (Non-US Companies), ESG Analytics, 2007.

RiskMetrics Group (2009): Corporate Governance Quotient - Corporate Governance Rating to evaluate Risk, 2009.

RiskMetrics Group (2010): Governance Risk Indicators 2010 - A New Measure of Governance-Related Risk, RiskMetrics Group, White Paper, 2010.

Rose, P. (2007): The Corporate Governance Industry, in: Journal of Corporation Law, Vol. 32 No. 4 (2007), pp. 887-926.

Roychowdhury, S. (2006): Earnings Management though real activities manipulation, in: Journal of Accounting and Economics, Vol. 42 No. 3 (2006), pp. 335-370.

Schillhofer, A. (2003): Corporate Governance and Expected Stock Returns - Empirical Evidence from Germany. Wiesbaden 2003.

Schmidt, R. H. / Weiß, M. (2003): Shareholder vs. Stakeholder: Ökonomische Fragestellungen. in: Handbuch Corporate Governance, publ. by P. Hommelhoff et al., Stuttgart, 2003, pp. 107-127.

Shivakumar, L. (2000): Do firms mislead investors by overstating earnings before seasoned equity offerings? in: Journal of Accounting and Economics, Vol. 29 No. 3 (2000), pp. 339-371.

Shleifer, A. / Vishny, R. W. (1997): A Survey of Corporate Governance, in: The Journal of Finance, Vol. 52 No. 2 (1997), pp. 737-783.

Sloan, R. G. (2001): Financial accounting and corporate governance: a discussion, in: Journal of Accounting and Economics, Vol. 32 No. 1-3 (2001), pp. 335-347.

Song, C. J. / Thomas, W. B. / Yi, H. (2010): Value Relevance of FAS No. 157 Fair Value Hierarchy Information and the Impact of Corporate Governance Mechanisms, in: The Accounting Review, Vol. 85 No. 4 (2010), pp. 1375-1410.

Spellman, K. G. / Watson, R. (2009): Corporate Governance Ratings and Corporate Performance: An Analysis of Governance Metrics International (GMI) ratings of US Firms, 2003 to 2008, University of Wisconsin, SSRN Working Paper, 2009. 
Stock, J. H. / Yogo, M. (2005): Testing for Weak Instruments in Linear IV Regression. in: Identification and Inference for Econometric Models: Essays in Honor of Thomas Rothenberg, publ. by D.W.K. Andrews \& J.H. Stock, Cambridge, 2005, pp. 80-108.

Strine, L. E. (2005): The Delaware Way: How we do corporate law and some of the new challanges we (and Europe) face, in: Delaware Journal of Corporate Law, Vol. 30 (2005), pp. 673-696.

Van der Elst, C. (2004): Industry-specificities and size of corporations: determinants of ownership structures, in: International Review of Law and Economics, Vol. 24 (2004), pp. 425-446.

Vander Bauwhede, H. (2009): On the relation between corporate governance compliance and operating performance, in: Accounting and Business Research, Vol. 39 No. 4 (2009), pp. 497-513.

Vo, T. (2008): Rating Management Behavior and Ethics: A Proposal to Upgrade the Corporate Governance Rating Criteria, in: The Journal of Corporate Law, Vol. 34 No. 1 (2008), pp. 1-41.

White, H. (1980): A Heteroskedasticity-Consistent Covariance Matrix Estimator and a Direct Test for Heteroskedasticity, in: Econometrica, Vol. 48 No. 4 (1980), pp. 817-838.

Young, S. (2008): Discussion of Do Acquirers Manage Earnings Prior to a Share for Share Bid, in: Journal of Business Finance and Accounting, Vol. 35 No. 5 (2008), pp. 671678.

Yu, F. (2008): Analyst coverage and earnings management, in: Journal of Financial Economics, Vol. 88 (2008), pp. 245-271.

Zang, A. Y. (2012): Evidence on the Trade-Off between Real Activities Manipulation and Accrual-Based Earnings Management, in: The Accounting Review, Vol. 87 No. 2 (2012), pp. 675-703. 


\section{EIDESSTATTLICHE VERSICHERUNG}

Ich versichere an Eides Statt, dass ich die eingereichte Dissertation "Corporate Governance, Information Intermediation, and Earnings Management" selbstständig verfasst habe. Anderer als der von mir angegebenen Hilfsmittel und Schriften habe ich mich nicht bedient. Alle wörtlich oder sinngemäß den Schriften anderer Autorinnen und/oder Autoren entnommenen Stellen habe ich kenntlich gemacht.

Ort, Datum

Unterschrift 


\section{LEBENSLAUF}

\section{PERSÖNLICHES}

Geburtsdatum \& -ort:

6. Dezember 1982, Kyritz (Brandenburg)

Nationalität:

Deutsch

\section{BILDUNG}

Seit $01 / 2010$

$10 / 2006-09 / 2009$

$04 / 2003-09 / 2006$

$1995-06 / 2002$

\section{Georg-August-Universität Göttingen: Promotion}

Wissenschaftlicher Mitarbeiter und Doktorand am Lehrstuhl für

Rechnungslegung und Wirtschaftsprüfung (Prof. Dr. Jörg-Markus Hitz)

Universität Hamburg: MiBA Programm

Abschluss: Master of Arts

Auslandssemester an der Copenhagen Business School, WiSe 2007

Universität Hamburg: Betriebswirtschaftslehre

Abschluss: Diplom Betriebswirt

Auslandssemester am Institute of Technology Tralee (Irland), WiSe 2005

"Friedrich Ludwig Jahn” Gymnasium, Kyritz

Abschluss: Abitur

\section{BERUFSERFAHRUNG}

11/2006-09/2009

\section{Helmut-Schmidt-Universität (HSU), Hamburg}

Studentische Hilfskraft am Lehrstuhl für ABWL und Internationaler

Finanzierung (Prof. Dr. Matija D. Mayer-Fiedrich)

$02 / 2008-06 / 2008$

RiskMetrics Group, Inc., Brüssel (Belgien)

Praktikum im Bereich ISS Governance Services

\section{ZUSÄTZLICHE INFORMATIONEN}

Sprachen:

Deutsch (Muttersprache),

Englisch (verhandlungssicher),

Franzözisch (Grundkenntnisse)

Ort: Göttingen

Datum: 03/07/2014

Unterschrift: 